\title{
CARACTERIZAÇÃO E CORRELAÇÃO DE INCLUSÕES SÓLIDAS EM PIRITA COM ALTERAÇÕES HIDROTERMAIS NO PÓRFIRO DE COBRE DE CUAJONE - PERÚ
}

Carmen Juli Sucapuca Goyzueta

Orientador: Prof. Dr. Silvio Roberto Farias Vlach

DISSERTAÇÃO DE MESTRADO

Programa de Pós-Graduação em Mineralogia e Petrologia

São Paulo

2008 

A la memória de mi querido padre Gumercindo y a mi madre Luz....... Muchas gracias por el constante apoyo!! 

Deus não escolhe os capacitados capacita os escolhidos,

Fazer ou não fazer algo só depende de nossa vontade e perseverança,

A mente que se abre a uma nova idéia jamais voltará ao seu tamanho original.

(Albert Einsten) 



\section{Agradecimentos}

- Em primeiro lugar, agradeço imensamente a Deus pelas numerosas oportunidades colocadas em minha vida, pelo acompanhamento e confiança depositada neste trabalho.

- Ao Instituto de Geociências da Universidade de São Paulo pela formação acadêmica e a disposição de seus laboratórios.

- Ao CNPq pela concessão da bolsa de mestrado.

- A meu orientador professor Dr. Silvio Roberto Farias Vlach por ter-me dado a oportunidade de fazer estudos de pós-graduação e pela orientação neste processo de formação.

- À empresa Souther Perú Copper Corporation, ao Departamento da Unidade Mineira Cuajone, em especial aos Engs. Geólogos Elsiario Antunez de Maiolo, Diretor de operações de Cuajone; Oscar Concha, Superintendente de geologia; Heller Bernabé ex-Superintendente de engenharia de minas, pela liberação de amostras e por fornecer informação, mapas e perfis. Agradeço também ao apoio logístico oferecido pelos Engs. Geólogos do Departamento de Explorações: Edgard Corrales, Diretor de explorações e Fernando Nuñez, Gerente de explorações. Aos Engs. Geólogos Bertin Herrera e Jesus Chara que participaram na etapa de seleção de amostras.

- Ao Instituto Geológico Minero e Metalúrgico INGEMMET-Perú, em especial ao Eng. Geólogo Dr. José Macharé ex-Diretor Técnico por fornecer a disposição seus laboratórios e a preparação de um grupo de amostras na etapa inicial do projeto. Ao técnico Edilberto Mena do laboratório de petrotomia pela preparação de amostras.

- Ao Eng. Geólogo Dr. Humberto Chirif por ter-me incentivado a realizar estudos de pósgraduação no extrangeiro.

- A minha grande amiga geóloga Livia Fernanda Chavez dos Santos pela sua valiosa amizade, apoio e incentivo nos momentos difíceis e pelas alegrias compartidas.

- Agradecimentos especiais a meus amigos Carlos Carrasco e Henry Javier pela ajuda nas etapas finais do trabalho, também agradeço a Gabriel Cabrera, Nilo Cano, Luz Roldan e Carola Cavero, pelo companheirismo e assistência. A meus amigos do apartamento no CRUSP Alan Alves e Rowenha Mattos pelo convívio, apoio e conselhos dados.

- Aos colegas de pós-graduação Gaston, Lucelene, Rogério, Tatiana, Frederico, Adriana, Liza, Renato, John, Paula, Claudia, Silvia, Roseane, Cintya, Milene, Fatima pelo convívio e amizade. - Aos técnicos: Angélica Morente, Marcos Mansueto e José Paulo Sertek, dos laboratórios de microscopia, microssonda eletrônica e preparação de amostras pela colaboração no trabalho.

- Aos funcionários administrativos Ana Paula Cabanal, Magali Poli e Tadeu pela disposição 
prestada.

- Em especial a minha mãe Luz Goyzueta por ser um exemplo de fortaleza e perseverança e por me ensinar a nunca desistir de meus objetivos. Por todo o carinho e o apoio dado em todas as minhas escolhas e estar sempre ali nos momentos mais difíceis de minha vida.....muchas gracias mi lucecita del saber!.

- A meus irmãos Ronald, Raúl, Ruth, Gina e Miriam por o apoio moral, carinho e amizade de sempre. Los re-quiero!.

- A Yoel Rodriguez pela companhia e apoio na etapa final do trabalho. 


\section{Resumo}

A mina Cuajone é uma jazida de tipo pórfiro de cobre (porphyry copper), localizada na Província Cuprífera do Pacífico, nos flancos ocidentais da Cadeia Andina, no estado de Moquegua, sul do Perú, em coordenadas $17^{\circ} 02^{\prime}(\mathrm{S})$ e $70^{\circ} 42^{\prime}(\mathrm{W})$ e altitudes entre 3100 e 3830 m. A região é caracterizada pela ocorrência, na base, de derrames vulcânicos (andesitos e riolitos) cretácicos do Grupo Toquepala, que são invadidos por um complexo intrusivo (quartzo monzonitos - quartzo latitos) associado à mineralização. Fluxos vulcânicos mais recentes, compostos principalmente por traquitos, tufos e aglomerados traquíticos e conglomerados riolíticos das Formações Huaylillas e Chuncatala recobrem todo o conjunto.

A análise petrográfica de 77 amostras representativas de 22 testemunhos de furos de sondagem distribuídos em três perfis da jazida de Cuajone permitiu a caracterização das seguintes rochas: andesitos, riolitos, quartzo latitos, latitos, micro-granodioritos porfiríticos, microtonalitos porfiríticos, pórfiros-I (micro quartzo monzonitos - micro monzogranitos (?)), pórfirosII (micro tonalitos - micro leucoquartzo dioritos (?)) e micro-brechas. Estas rochas encontramse afetadas por alterações hidrotermais em graus variáveis, identificando-se oito tipos ou combinações de tipos principais: potássica, potássica-propílica, propílica-potássica, potássica-propílica/fílica, propílica, propílica-fílica, fílica-propílica e fílica.

O exame microscópico em detalhe sob luz refletida das fases sulfetadas demonstrou que a pirita (py), o sulfeto mais abundante, apresenta freqüentemente inclusões diminutas de calcopirita, cp, (X0,0 e 0,X $\mu \mathrm{m})$, quase sempre acompanhada de pirrotita (po), cubanita (cb) e mackinawita (mck), que aparecem formando intercrescimentos típicos. Estas inclusões apresentam formas arredondadas, ovais ou mesmo idiomórficas que, devido às suas dimensões, quase sempre não são reconhecidas em exames convencionais ao microscópio.

Os intercrescimentos identificados foram classificados de acordo com a sua morfologia, utilizando-se para tanto de nomenclatura específica, e suas abundâncias relativas. Os resultados mostram que os mais abundantes são: tipo cp/po:1b (calcopirita + pirrotita, morfologia de tipo 1b) e py/po:1e na zona de alteração potássica, py/po:1e e cp/mck:4f nas zonas potássicapropílica e propílica-potássica, cp/mck:4f e py/po:1e na zona propílica e cp/po:1b e cp/mck:4f nas zonas de alteração potássica-propílica/fílica, propílica-fílica, fílica-propílica e zona de alteração fílica.

A análise de distribuição das inclusões/intercrescimentos indica que a sua mineralogia pode 
ser correlacionada com a tipologia da alteração hidrotermal, particularmente quando se consideram as freqüências e/ou abundâncias relativas. Assim, observa-se que a pirrotita ocorre em todos os tipos de alteração, porém sua freqüência é notadamente superior nas amostras com alteração potássica. A cubanita, ainda que seja pouco abundante, é freqüente nas zonas onde há contribuição da alteração fílica. Apesar de ser encontrada também nas zonas potássica-propílica e propílica-potássica, a sua freqüência é praticamente insignificante quando comparada com a das demais fases encontradas, enquanto a mackinawita apresenta freqüência significativamente superior nas rochas afetadas pela alteração propílica. A tipologia e a distribuição das inclusões/intercrescimentos, aliadas às informações experimentais disponíveis para o diagrama de fases Cu-Fe-S, são compatíveis com temperaturas entre ca. 180 e $500{ }^{\circ} \mathrm{C}$ para a origem da mineralização de $\mathrm{Cu}$ (calcopirita, cubanita). 


\section{Abstract}

The Cuajone mine is a porphyritic copper deposit (porphyry copper), located in the Pacific Copper Province, eastern flanks of the Andean Cordillera, state of Moquegua, south of Peru, with geographic coordinates $17^{\circ} 02$ '(S) and $70^{\circ} 42^{\prime}(\mathrm{W})$ and altitudes between 3100 and 3830 $\mathrm{m}$. The region is characterized from base to top by cretaceous volcanics (andesites and rhyolites) from Toquepala Group, which are invaded by a intrusive complex (quartz monzonites-quartz latites) associated to the ore deposits. Covering these units there are more recent volcanic flows composed mainly by trachyte, trachytic tuff, rhyolitic conglomerates and trachytic agglomerate from Huaylillas and Chuncatala Formations.

Petrographic analysis of 77 samples representing 22 drilling cores distributed in three profiles of Cuajone Mine allowed the identification of the following lithotypes: andesite, rhyolite, quartz latite, latite, porphyritic micro-granodiorite, porphyritic micro-tonalite, porphyry-I (micro quartz monzonites-monzogranites (?)), porphyry-II (micro tonalites-micro leucoquartz diorites (?)) and micro-breccias. These rocks are affected by variable degrees of hydrothermal alteration with predominance of eight types or combinations of the following main types: potassic, potassic-propylitic, propylitic-potassic, potassic-propylitic/phylic, propylic, propylitic-phylic, phylic and propylitic-phylic.

Detailed microscopic investigation under reflected light revealed that among the sulphide phases, pyrite (py) is the most abundant, with frequent chalcopyrite (cp) tiny inclusions (X0, 0 and $0, \mathrm{X} \mu \mathrm{m}$ ), almost always accompanied by pirrotite (po), cubanite (cb) and mackinawite (mck), occurring as typical intergrowths. These inclusions show round to oval or idiomorphic shapes and are commonly overlooked during conventional microscopic analyses due to their small dimensions.

The intergrowths identified during petrographic analysis were classified according to their morphology, using specific nomenclature and relative abundances. The results show that the most abundant types are: cp/po:1b (chalcopyrite + pirrotite, morphology type 1b) and py/po:1e in the potassic alteration zone, py/po:1e and cp/mck:4f in areas of potassic-propylitic and propylitic-potassic alteration, $\mathrm{cp} / \mathrm{mck}: 4 \mathrm{f}$ and py/po:1e in the propylitic zone and $\mathrm{cp} / \mathrm{po}: 1 \mathrm{~b}$ and $\mathrm{cp} / \mathrm{mck}: 4 \mathrm{f}$ in potassic-propylic/phylic alteration zones; propylitic-phylic, phylic-propylitic and phylic zones.

The distribution pattern of inclusions/intergrowths indicates that their mineralogy can be 
correlated with the type of hydrothermal alteration. This is particularly evident when considering frequency and/or relative abundance. Thus, pirrotite occurs in all types of alteration, although its frequency is especially higher in samples with potassic alteration. Cubanite is more characteristic in the potassic-propylic and propylic-potassic zones, while mackinawite is significantly more frequent in rocks affected by propylic alteration.

The type and distribution of inclusions/intergrowths, allied to current experimental results for the $\mathrm{Cu}-\mathrm{Fe}-\mathrm{S}$ system, are compatible with temperatures between ca. 180 and $500^{\circ} \mathrm{C}$ for the genesis of the studied copper deposits (chalcopyrite, cubanite). 


\section{Sumário}

Lista de Figuras $\quad$ xiii

Lista de Tabelas $\quad$ xvii

1 Introdução 1

1.1 Considerações Iniciais $\ldots \ldots \ldots \ldots$. . . . . . . . . . . . . . . . 1

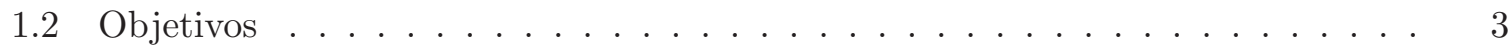

1.3 Localização, extensão e acesso à Jazida de Cuajone . . . . . . . . . . . . . . . . 3

2 Jazidas de cobre de tipo pórfiro $\quad 5$

2.1 Caracterização Geral e Modelos . . . . . . . . . . . . . . . . . . . 5

2.2 As jazidas de $\mathrm{Cu}$ de tipo pórfiro no Perú . . . . . . . . . . . . . . 8

3 A jazida de Cuajone $\quad 13$

3.1 Aspectos fisiográficos e geomorfológicos . . . . . . . . . . . . . . . . 13

3.1 .1 Relevo . . . . . . . . . . . . . . . . . . . . . 13

3.1 .2 Clima ............................... 13

3.1.3 Unidades geomorfológicas regionais . . . . . . . . . . . . . . . . . 13

3.2 Geologia da Região de Cuajone . . . . . . . . . . . . . . . . . . . . . . 15

3.2 .1 Unidades Geológicas . . . . . . . . . . . . . . . . . . . . . 15

3.2 .2 Rochas Intrusivas . . . . . . . . . . . . . . . . . . . 16

3.2.3 Estruturas Regionais . . . . . . . . . . . . . . . . . . . . 17

3.3 Geologia Local da Jazida de Cuajone . . . . . . . . . . . . . . . . . . . . 18

3.3 .1 Rochas Pré-mineralização . . . . . . . . . . . . . . . . . . . 18

3.3.2 Rochas Intrusivas . . . . . . . . . . . . . . . . . . . . . . 21

3.3.3 Rochas Pós-Mineralização . . . . . . . . . . . . . . . . . . 23

3.4 Geologia Estrutural Local . . . . . . . . . . . . . . . . . . . . . 25

3.4 .1 Fraturas e falha . . . . . . . . . . . . . . . 25

4 Materiais e métodos $\quad 27$

4.1 Amostragem . . . . . . . . . . . . . . . . . . . 27

4.2 Coloração Seletiva de Feldspato . . . . . . . . . . . . . . . . . . 28 
4.3 Petrografia microscópica . . . . . . . . . . . . . . . . . . . . . . . . 28

4.4 Imageamento composicional e Química Mineral . . . . . . . . . . . . . . . . . . 31

4.4.1 Imagens de Elétrons Retro-espalhados (BSE) . . . . . . . . . . . . . 33

4.4 .2 Análises pontuais quantitativas . . . . . . . . . . . . . 33

4.4 .3 Mapas Composicionais . . . . . . . . . . . . . . . . . . . . 34

4.5 Tratamento de Dados Gerais . . . . . . . . . . . . . . . . 35

5 Petrografia geral $\quad 37$

5.1 Andesitos . . . . . . . . . . . . . . . . . . . 37

5.2 Riolitos . . . . . . . . . . . . . . . . . . . . 40

5.3 Quartzo latitos . . . . . . . . . . . . . . . . . . . . 40

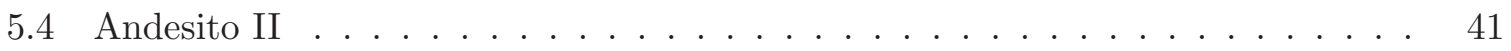

5.5 Latito . . . . . . . . . . . . . . . . . . . . . 43

5.6 Micro-granodioritos porfiríticos . . . . . . . . . . . . . . 43

5.7 Micro-tonalitos . . . . . . . . . . . . . . . . . . . 44

5.8 Pórfiros I (micro quartzo monzonitos - micro monzogranitos) . . . . . . . . 46

5.9 Pórfiros II (micro tonalitos - micro leucoquartzo dioritos) . . . . . . . . . 47

5.10 Micro-brecha . . . . . . . . . . . . . . . . . . . . . . 49

6 Alterações Hidrotermais $\quad 51$

6.1 Caracterização e tipologia . . . . . . . . . . . . . . . . . . . . 51

6.2 Alterações hidrotermais na jazida Cuajone . . . . . . . . . . . . . . . . 54

6.2 .1 Andesitos . . . . . . . . . . . . . . . . . 54

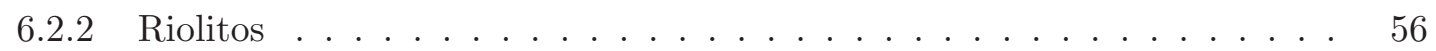

6.2 .3 Quartzo latito ........................ 57

6.2 .4 Andesito II . . . . . . . . . . . . . . . . . . . . . 57

6.2 .5 Latito . . . . . . . . . . . . . . . . . . . . 57

6.2 .6 Micro-granodioritos porfiríticos . . . . . . . . . . . . . 59

6.2 .7 Micro-tonalitos . . . . . . . . . . . . . . . . . . 59

6.2.8 Pórfiros I (micro quartzo monzonitos - micro monzogranitos) . . . . . . 61

6.2.9 Pórfiros II (micro tonalitos - micro leucoquartzo dioritos) . . . . . . . . 61

6.2 .10 Micro-brecha . . . . . . . . . . . . . . . . . . 62

6.2 .11 Pórfiros alterados . . . . . . . . . . . . . . . . . 62

6.2 .12 Hidrotermalitos . . . . . . . . . . . . . . . . . . . . . 64

7 Caracterização e distribuição das inclusões e intercrescimentos $\quad 67$

7.1 Inclusões e intercrescimentos: Ocorrência e importância . . . . . . . . . . . 67

7.1 .1 Introdução . . . . . . . . . . . . . . . . . . 67

7.1.2 Importância das Inclusões e intercrescimentos nos Pórfiros Peruanos . . 68

7.1.3 Inclusões Sólidas no Pórfiro de Cuajone . . . . . . . . . . . . . . . . . . 69

7.2 Caracterização química dos intercrescimentos e inclusões . . . . . . . . . . . . . 74 
7.2 .1 Mapas composicionais . . . . . . . . . . . . . . . . . . 74

7.2 .2 Análises pontuais quantitativas . . . . . . . . . . . . . 83

7.3 Freqüências e distribuição estatística das inclusões e intercrescimentos . . . . . 90

7.4 Correlação entre os tipos de Intercrescimentos e as Alterações Hidrotermais . . 93

7.5 Alteração potássica-propílica/fílica . . . . . . . . . . . . . . . . . . . 98

7.6 Minerais que Constituem os Intercrescimentos . . . . . . . . . . . . . . . . 103

8 Síntese, considerações finais e recomendações $\quad 107$

8.1 Litologias e tipologia das alterações hidrotermais . . . . . . . . . . . . . . 107

$8.1 .1 \quad$ Perfil $1 \ldots \ldots \ldots \ldots \ldots$. . . . . . . . . . . . . . . . . . . . . . . .

$8.1 .2 \quad$ Perfil $2 \ldots \ldots \ldots \ldots \ldots$

8.1 .3 Perfil $3 \ldots \ldots \ldots \ldots \ldots \ldots$

8.2 Inclusões e intercrescimentos em fases sulfetadas . . . . . . . . . . . . . . . 111

8.2.1 Quimismo e seqüência de cristalização das fases minerais sulfetadas . . . 112

8.2 .2 Relações de fase no sistema Cu-Fe-S . . . . . . . . . . . . . . . . 115

8.2.3 Intercrescimentos mais importantes entre calcopirita, pirrotita, cubanita e mackinawita . . . . . . . . . . . . . . . . . 118

8.3 Conclusões e recomendações . . . . . . . . . . . . . . . . . . 125

$\begin{array}{lr}\text { Referências Bibliográficas } & 129\end{array}$

$\begin{array}{ll}\text { Anexos } & 139\end{array}$ 



\section{Lista de Figuras}

1.1 Mapas de localização da Jazida de Cuajone, Perú (Concha \& Bernabé, 1999). . . . . .

2.1 Distribuição das zonas de alteração hidrotermal em uma jazida de $\mathrm{Cu}$ do tipo pórfiro, combinando os modelos de Lowell \& Guilbert (1970), Gustafson \& Hunt (1975), Giggenbach (1997), de acordo com Maksaev (2001) . . . . . . . . . . . . . . .

2.2 Distribuição de minerais da zona mineralizada em um típico depósito de pórfiro de Cobre. py $=$ pirita, $\mathrm{cp}=$ calcopirita, $\mathrm{mb}=$ molibdenita, $\mathrm{mt}=$ magnetita., de acordo com Maksaev (2001). . . . . . . . . . . . . . . . . . . . .

2.3 Zoneamento produzido por efeitos supérgenos em uma jazida de $\mathrm{Cu}$ do tipo pórfiro. De cima para baixo: Gossam ou chapéu de ferro, caracterizado por óxidos e hidróxidos de ferro; zona lixiviada, com conteúdo escasso de metais; zona oxidada, com concentração de minerais oxidados de cobre (crisocola, atacamita, malaquita); zona de enriquecimento supérgeno, caracterizada pela concentração de sulfetos secundários de $\mathrm{Cu}$ (calcosina, covelina, digenita, bornita); zona primária ou hipógena não afetada, com sulfetos primários (pirita, calcopirita, bornita). Segundo Maksaev (2001). . . . . . . .

2.4 Principais unidades geológicas e segmentação do Batólito Costeiro do Perú. Modificado de Pitcher \& Cobbing (1985) e Cobbing (1998). . . . . . . . . . . . . . . . .

2.5 Distribuição regional das jazidas de Cu do tipo pórfiro no Perú. Aguilar et al. (1974) reconhece um total de 40 depósitos (em vermelho), enquanto Singer (2005) os agrupa em 36 ocorrências (em azul). Os nomes utilizados pelo último autor são referidos no

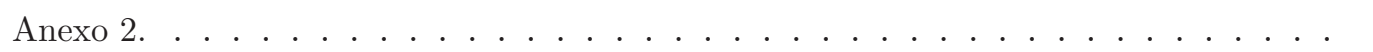

3.1 Principais unidades geomorfológicas regionais, segundo Clark et al. (1990b). . . . . . . 14

3.2 Coluna Estratigráfica da mina Cuajone, de acordo com Concha \& Bernabé (1999). 19

3.3 Geologia Local da mina Cuajone, de acordo com Concha \& Bernabé (1999). . .

4.1 Localização e distribuição dos furos de sondagem das três seções construídas na Jazida de Cuajone. . . . . . . . . . . . . . . . . . . . . . . . .

4.2 Principais tipos de intercrescimentos entre fases sulfetadas, de acordo com Canchaya \& Cardoso (1984). . . . . . . . . . . . . . . . . . . . . .

4.3 Fotografia tomada da Microssonda Eletrônica do Departamento de Mineralogia e Geotectônica do Instituto de Geociências da Universidade de São Paulo. . . . . . . . . . 
4.4 Defocagem WDS durante a confecção do mapa composicional, de acordo com Goldstein et al. (1992). . . . . . . . . . . . . . . . . . .

7.1 Perfil 1 com a seleção dos tipos de rocha (B-1, D-5 e F-1) mais representativas as quais deram melhores resultados nos analises da microssonda eletrônica. Cotas e profundidades são dadas na parte superior e inferior de cada furo respectivamente, as coordenadas são representadas em UTM. . . . . . . . . . . . . . . . . . . . . . .

7.2 Perfil 2 com a seleção da rocha J-4 mais representativa a qual mostro melhores resultados nos analises da microssonda eletrônica. Cotas e profundidades são dadas na parte superior e inferior de cada furo respectivamente, as coordenadas são representadas em UTM.

7.3 Perfil 3 com a seleção das rochas M-5 e Q-3 mais representativas as quais mostraram melhores resultados nos analises da microssonda eletrônica. Cotas e profundidades são dadas na parte superior e inferior de cada furo respectivamente, as coordenadas são representadas em UTM. . . . . . . . . . . . . . . . . . . . . . . . .

7.4 Porcentagem relativa dos diferentes tipos de intercrescimentos mais freqüentes na Jazida Cuajone. . . . . . . . . . . . . . . . . . . .

7.5 Freqüência relativa dos intercrescimentos mais abundantes nas jazidas Cuajone, Cerro Verde, Toromocho e Quellaveco. . . . . . . . . . . . . . . . .

7.6 Freqüência comparativa dos intercrescimentos mais abundantes nas zonas de alteração potássica. . . . . . . . . . . . . . . . . .

7.7 Freqüência dos minerais que tipificam todos os intercrescimentos observados nas zonas de alteração potássica. . . . . . . . . . . . . . . . . . . .

7.8 Frequência dos minerais que tipificam os intercrescimentos mais abundantes nas zonas de alteração potássica. . . . . . . . . . . . . . . . . . . . . .

7.9 Freqüência comparativa dos intercrescimentos mais abundantes nas zonas de alteração potássica-propílica. . . . . . . . . . . . . . . . . . .

7.10 Freqüência dos minerais que tipificam os intercrescimentos nas zonas de alteração potássicapropílica. . . . . . . . . . . . . . . . . . . . . .

7.11 Freqüência comparativa dos intercrescimentos mais abundantes nas zonas de alteração propílica-potássica. . . . . . . . . . . . . . . . . . . . .

7.12 Freqüência dos minerais que tipificam os intercrescimentos nas zonas de alteração propílica-

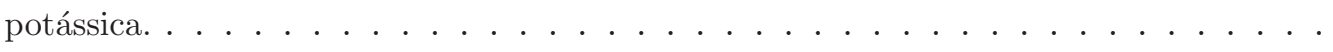

7.13 Freqüência comparativa dos intercrescimentos mais abundantes nas zonas de alteração propílica. . . . . . . . . . . . . . . . . . . . . . . 98

7.14 Freqüência dos minerais que tipificam os intercrescimentos nas zonas de alteração propílica. 98

7.15 Freqüência comparativa dos intercrescimentos mais abundantes nas zonas de alteração potássica-propílica, fílica. . . . . . . . . . . . . . . . . . .

7.16 Freqüência dos minerais que tipificam os intercrescimentos nas zonas de alteração potássicapropílica, filica. . . . . . . . . . . . . . . . . . . . . 
7.17 Freqüência comparativa dos intercrescimentos mais abundantes nas zonas de alteração propílica-fílica. . . . . . . . . . . . . . . . . . . . . . . .

7.18 Freqüência dos minerais que tipificam os intercrescimentos nas zonas de alteração propílicafílica. . . . . . . . . . . . . . . . . . . . . . . .

7.19 Freqüência dos minerais que tipificam os intercrescimentos nas zonas de alteração propílicafílica, considerando todos os intercrescimentos descritos. . . . . . . . . . . . . . .

7.20 Freqüência comparativa dos intercrescimentos mais abundantes nas zonas de alteração fílica-propílica. . . . . . . . . . . . . . . . . . . . . .

7.21 Freqüência dos minerais que tipificam os intercrescimentos nas zonas de alteração fílicapropílica. . . . . . . . . . . . . . . . . . . . . .

7.22 Freqüência comparativa dos intercrescimentos mais abundantes nas zonas de alteração fílica. . . . . . . . . . . . . . . . . . . . . .

7.23 Freqüência comparativa dos intercrescimentos mais abundantes nas zonas de alteração fílica. . . . . . . . . . . . . . . . . . . . .

8.1 Localização do perfil 1 com seus respectivos furos de sondagem A-G indicando as rochas e os tipos de alteração hidrotermal presentes, representados com auxílio do programa Datamine. As cotas e profundidades são dadas na parte superior e inferior de cada furo respectivamente, as coordenadas são representadas em UTM. Ver o significado de abreviaturas dos tipos de rocha e alterações hidrotermais no Anexo 1. . . . . . . . . .

8.2 Localização do perfil 2 com seus respectivos furos de sondagem H, I e J indicando as rochas e os tipos de alteração hidrotermal presentes, representados com auxílio do programa Datamine. As cotas e profundidades são dadas na parte superior e inferior de cada furo respectivamente, as coordenadas são representadas em UTM. Ver o significado de abreviaturas dos tipos de rocha e alterações hidrotermais no Anexo 1. . . . . . . .

8.3 Localização do perfil 3 com seus respectivos furos de sondagem $\mathrm{K}-\mathrm{V}$ indicando as rochas e os tipos de alteração hidrotermal presentes, representados com auxílio do programa Datamine. As cotas e profundidades são dadas na parte superior e inferior de cada furo respectivamente, as coordenadas são representadas em UTM. Ver o significado de abreviaturas dos tipos de rocha e alterações hidrotermais no Anexo 1. . . . . . . . . .

8.4 Campos de estabilidade dos principais sulfetos (Craig \& Scott, 1974), óxidos de ferro Meyer \& Hemley (1967) e Ti (Udubasa, 1982) no diagrama $f_{O 2}$ vs. $f_{S 2}$. A tabela anexada na parte inferior da Figura corresponde às zonas hachuradas do gráfico de acordo com Meyer \& Hemley (1967), onde se apresentam as assembléias de minerais opacos características associadas às alterações e exemplos de jazidas típicas. Ver significado de abreviaturas dos minerais no Anexo 1. . . . . . . . . . . . . . . . . . .

8.5 Diagrama da possível seqüência de cristalização dos minerais estudados em função da fugacidade de $\mathrm{S}_{2}$. Ver significado de abreviaturas dos minerais no Anexo 1. . . . . . . 
8.6 Relações de fase na porção central do sistema Fe-Cu-S a $600{ }^{\circ} \mathrm{C}$. Nesta temperatura são observados três campos extensos de solução solida: bornita (bn ou SSbor), solução sólida intermediaria (iss ou SSI) e pirrotita (po ou SSpo). Em temperaturas inferiores, gera-se uma solução sólida de calcopirita (SScp) a partir do desmembramento da SSI. Ver Anexo 1 para as abreviaturas. Fonte: Fleet (2006). . . . . . . . . . . . . . . . 116

8.7 Diagrama quaternário calcopirita-cubanita-pirrotita-mackinawita ilustrando os tipos de intercrescimentos mais freqüentes descritos para a jazida de Cuajone. Os pontos são posicionados qualitativamente no diagrama. Abreviaturas representadas no Anexo 1. . 119

8.8 Relação de fases para diferentes temperaturas entre os minerais que aparecem como inclusões sólidas em pirita na jazida Cuajone. SSI = solução sólida intermediária, SSpo = solução sólida de pirrotita, SScp = solução sólida de calcopirita. Abreviaturas dos minerais no Anexo 1. . . . . . . . . . . . . . . . . . . . . 121 


\section{Lista de Tabelas}

4.1 Características gerais da rotina utilizada para análise WDS de sulfetos. . . . . . . . .

7.1 Ocorrência da assembléia py-cp-po-cb-mck nos principais pórfiros de cobre peruanos, de acordo com Canchaya (1993). . . . . . . . . . . . . . . . . . . . .

7.2 (A) Análises químicas pontuais (WDS) para a pirita hospedeira de inclusões sólidas (bd = abaixo do limite de detecção). Análises de piritas da literatura: (a) pirita em granito de muscovita (análises WDS), (b) em piroxenitos-peridotitos serpentinizados (análises WDS) e (c) em rocha hospedeira não descrita na zona da mina Elba, Italia (análises químicas convencionais). (B) Fórmula estrutural. . . . . . . . . . . . . . . . .

7.3 Análises químicas pontuais (WDS) para inclusões de calcopirita (bd = abaixo do limite de detecção). Análises de calcopiritas da literatura: (a,b) em piroxenita-peridotita serpentinizada (análises WDS), (c) rocha hospedeira não descrita, mina Western, Vancouver Island, British Columbia, Canadá (análises WDS), (d) para $\mathrm{CuFeS}_{2}$ (análises químicas convencionais), (e) Mina Washi-aimori, Iwate Japan (análises químicas convencionais) e (f) em rochas de complexos máficos estratiformes, jazidas de sulfetos de Cu-Ni, Sudbury - Canada (análises químicas convencionais). (B) Fórmula estrutural. .

7.4 (A) Análises químicas pontuais (WDS) para inclusões de cubanita (bd = abaixo do limite de detecção). Análises de cubanitas da literatura: (a) rocha hospedeira não descrita, mina Barracanao, Cuba (análises químicas convencionais), (b) para $\mathrm{CuFe}_{2} \mathrm{~S}_{3}$ (análises químicas convencionais), (c) rocha hospedeira não descrita, mina Ohmine, Iwate Japan (análises químicas convencionais) e (d,e) em cubanitas de meteoritos (análises WDS). (B) Fórmula estrutural. . . . . . . . . . . . . . . . . . . . . . . . . .

7.5 (A). Análises químicas pontuais (WDS) para inclusões de pirrotita (bd = abaixo do limite de detecção). Análises de pirrotitas da literatura: (a) em rocha hospedeira de granito de muscovita associada à mineralização de Sn, mina Ervedosa - Portugal (análises WDS), (b,c) em piroxenita-peridotita serpentinizada (análises WDS), (d) rocha hospedeira não descrita, mina Homestake, de Pb, Lawrence Co. South Dakota, EE.UU. Fe:S=0.87 (análises químicas convencionais) e (e) em rochas de complexos máficos estratiformes, jazidas de sulfetos de Cu-Ni, Sudbury - Canada (análises químicas convencionais). (B) Fórmula estrutural. . . . . . . . . . . . . . . . . . . . . . . . 
7.6 (A). Análises químicas pontuais (WDS) para inclusões de mackinawita (bd = abaixo do limite de detecção). Análises de mackinawitas da literatura: (a,b) em andesitos alterados hidrotermalmente (kaolinitização), jazida de Hg, mina Moschellandsberg SW Alemanha (análises WDS), (c,d) em mina de cobre Chadmari, Rajasthan - India (análises WDS), (e) em calcopirita de serpentinita, mina de Ni, Outokumpo - Finlândia (análises WDS) e (f) em mina de $\mathrm{Cu}, \mathrm{Ni}, \mathrm{Au}$, Mackinaw, Washington - EEUU (análises WDS). (B) fórmula estrutural. . . . . . . . . . . . . . . . . . .

7.7 Divisão arbitrária de categorias para mostrar as freqüências dos minerais que constituem os intercrescimentos. . . . . . . . . . . . . . . . . . . . .

7.8 Freqüência dos minerais que formam as inclusões para as setenta e sete amostras estudadas. Ver abreviaturas dos minerais no Anexo $1 \ldots \ldots \ldots$. . . . . . . . . 


\section{1 \\ Introdução}

\subsection{Considerações Iniciais}

As jazidas de Cobre de tipo pórfiro (porphyry copper deposits) estão entre as mais importantes ocorrências de interesse econômico de metais básicos do mundo. São caracterizadas principalmente por apresentarem grandes tonelagens $\left(c a .10^{6}-10^{9} \mathrm{t}\right)$, mas baixos teores de $\mathrm{Cu}$ ( $c a$. 0,2 - 2,0 \% em peso). Além do $\mathrm{Cu}$, estas jazidas contêm abundâncias variáveis de outros elementos de interesse econômico (e.g., Mo, Au, Ag) em teores que os tornam subprodutos comuns do processo de beneficiamento. Estes depósitos apresentam tipicamente formas concêntricas a ovaladas, com contornos irregulares em planta e diâmetros que variam de centenas a milhares de metros; verticalmente apresentam formas tubulares ou em funil.

As atividades de exploração e o interesse neste tipo de jazidas se intensificaram na década de setenta e muitos trabalhos clássicos remontam a esta época. Nos anos noventa observou-se um incremento significativo na exploração de $\mathrm{Cu}$ e $\mathrm{Au}$ e nos interesses de pesquisa no tema. Entre os trabalhos que descrevem em detalhe as características da geologia, dos tipos de alteração hidrotermal e da mineralização em depósitos individuais de tipo pórfiro de $\mathrm{Cu}$, merecem ser citados, entre outros Titley \& Hicks (1966); Gustafson \& Titley (1978); Pierce \& Bolm (1995). As características mais típicas destas jazidas, descritas, entre outros, por Lowell \& Guilbert (1970); Rose (1970); Gustafson \& Hunt (1975); Giggenbach (1997), levaram à elaboração de modelos empíricos fundamentados no caráter concêntrico dos halos de alteração ( $c f$. Capítulo 2). De acordo com estes modelos, um zonamento seqüencial das alterações hidrotermais da zona central para as zonas periféricas ficaria bem caracterizado na forma: alteração potássica (conduzindo à formação de biotita + magnetita + K-feldspato), alteração fílica (quartzo + 
sericita), argílica (minerais de argila) e, finalmente, alteração propílica (clorita + epidoto + calcita).

Os sulfetos primários que caracterizam estas jazidas aparecem finamente disseminados, em veios e stockworks ou ainda em colunas de brechas (Sillitoe, 1985). Pirita e calcopirita são os principais minerais e constituem em geral ca. $90 \%$ do total de sulfetos. Em proporção relativamente reduzida ocorrem, entre outros, bornita, molibdenita, enargita, tetraedrita e traços de galena e esfalerita. Zonas de enriquecimento supérgeno são comuns, encontrando-se nelas principalmente calcosita, covelita, digenita e minerais oxidados de $\mathrm{Cu}$ tais como malaquita, crisocola e atacamita.

A mineralização de tipo disseminado predomina nas zonas centrais, enquanto a mineralização em veios é mais comum nas zonas periféricas da jazida. A distribuição dos sulfetos primários nas diferentes zonas mostra um incremento progressivo nas razões modais entre pirita e calcopirita nestes depósitos, que é da ordem de 3:1 na zona potássica, 12-13:1 na zona fílica e 23:1 na zona argílica, enquanto na zona propílica ocorre essencialmente pirita (e.g. Valera, 1987).

Assim, a pirita $\left(\mathrm{FeS}_{2}\right.$, cúbica) é o sulfeto mais abundante e o primeiro a ser depositado, encontrando-se distribuída por todo o depósito e estando associada particularmente às alterações propílica e argílica. A calcopirita $\left(\mathrm{CuFeS}_{2}\right.$, tetragonal) segundo sulfeto em abundância, é o único ou pelo menos o mais importante mineral de $\mathrm{Cu}$ de interesse econômico e está concentrada nas zonas centrais do depósito. Em algumas ocorrências a bornita aparece como segundo mineral de $\mathrm{Cu}$ importante (Valera, 1987).

Além dos minerais mencionados, outros encontram-se sempre associados, mas em quantidades muito subordinadas, com destaque para pirrotita $\left(\mathrm{Fe}_{1-x} \mathrm{~S}\right.$ polimorfos monoclínico, estável em temperaturas inferiores a $250{ }^{\circ} \mathrm{C}$, e hexagonal, estável em temperaturas mais elevadas) cubanita $\left(\mathrm{CuFe}_{2} \mathrm{~S}_{3}\right.$, ortorrômbica) e mackinawita $\left((\mathrm{Fe}, \mathrm{Ni}, \mathrm{Co})_{1+x} \mathrm{~S}\right.$, tetragonal). Estes aparecem tipicamente na forma de inclusões sólidas em pirita e formam intercrescimentos morfologicamente diversos com calcopirita.

A literatura sobre inclusões sólidas em sulfetos primários de depósitos de $\mathrm{Cu}$ de tipo pórfiro é relativamente escassa, particularmente no caso dos depósitos andinos do Perú. O único trabalho que examina este tema com algum detalhe é o de Canchaya (1993). Neste trabalho, o autor descreve as inclusões observadas em pórfiros peruanos e, entre eles, o de Cuajone e relata a ocorrência típica de pirrotita, cubanita e mackinawita associadas à calcopirita, esta encontrada principalmente como inclusões em pirita. O mesmo autor sugere também que as paragêneses formadas em temperaturas mais altas (pirrotita + calcopirita) são mais abundantes nas zonas centrais, enquanto as precipitadas sob temperaturas mais baixas (cubanita + mackinawita) são mais típicas das zonas externas do depósito. Assim, o estudo tipológico detalhado destas inclusões abre perspectivas interessantes para análises do zonamento mineralógico e suas correlações com as alterações hidrotermais. 


\subsection{Objetivos}

Neste panorama, a presente dissertação tem como objetivos principais a identificação, caracterização e análise da distribuição relativa das inclusões minerais presentes em pirita nas diferentes zonas de alteração hidrotermal da jazida de Cuajone, um dos depósitos mais importantes de $\mathrm{Cu}$ tipo pórfiro da região Sul do Perú, a correlação dos resultados com os diferentes tipos de rochas hospedeiras e com as alterações hidrotermais e a avaliação das possíveis implicações genéticas dos intercrescimentos observados entre estes minerais.

A escolha da Jazida de Cuajone deveu-se ao fato de que a sua mineralização é essencialmente hipógena e, por conseqüência, as inclusões não se encontram transformadas por eventos/enriquecimentos posteriores de natureza supérgena.

\subsection{Localização, extensão e acesso à Jazida de Cuajone}

A Jazida de Cuajone (Figura 1.1) localiza-se na denominada Província Cuprífera do Pacífico, nos flancos ocidentais da Cadeia Andina, no Estado de Moquegua, região Sul do Perú, mais precisamente nas coordenadas $17^{\circ} 02^{\prime}$ (S) e $70^{\circ} 42^{\prime}$ (W). Dista aproximadamente $40 \mathrm{~km}$ a noroeste da cidade de Moquegua e a $30 \mathrm{~km}$ da conhecida Jazida de Toquepala. O corpo mineralizado encontra-se em altitudes entre 3100 e 3830 m acima do nível do mar, na vertente Sul da quebrada (depressão profunda em uma cadeia de montanhas) Torata, que é cortado de Leste para Oeste pela quebrada Chuntacala.

A jazida apresenta forma ovalada em planta. O halo de alteração hidrotermal define um diâmetro aproximado de $4 \mathrm{~km}$, enquanto a zona mineralizada de interesse econômico apresenta diâmetros variáveis entre 950 e 1200 m (Satchwell, 1983).

O acesso à mina, a partir da capital Lima, é feito pela rodovia Panamericana Sul até a estrada que dá acesso para a cidade de Moquegua e continua até o depósito por uma distância de $8 \mathrm{~km}$. 


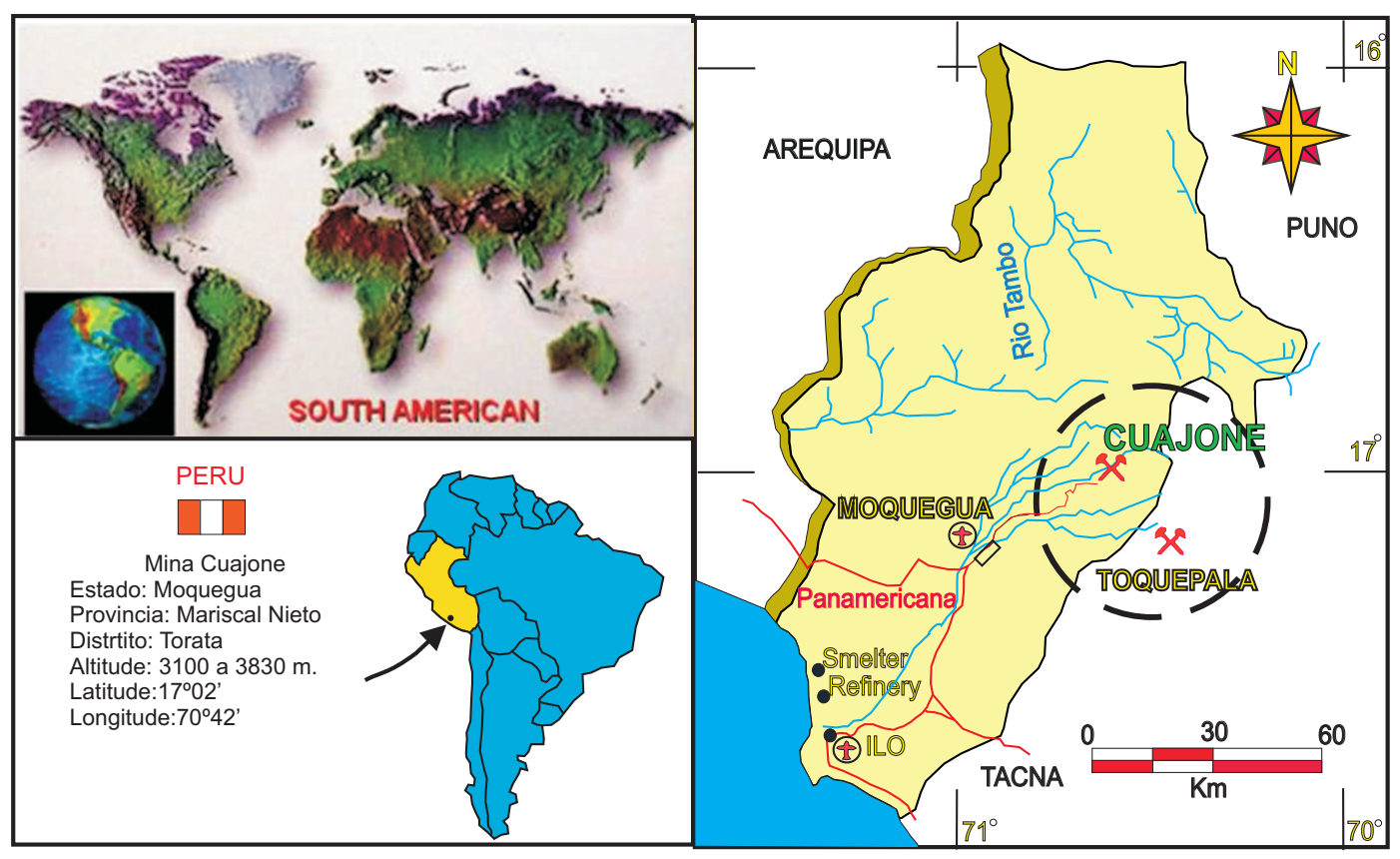

Figura 1.1: Mapas de localização da Jazida de Cuajone, Perú (Concha \& Bernabé, 1999). 


\section{2}

\section{Jazidas de cobre de tipo pórfiro}

\subsection{Caracterização Geral e Modelos}

As jazidas de $\mathrm{Cu}$ de tipo pórfiro estão intimamente relacionadas com ambientes orogênicos, de tectônica compressiva. De fato, é notável a ocorrência de jazimentos mesozóicos e cenozóicos ao longo da região circum-pacífica do planeta, e paleozóicos em cordilheiras orogênicas da antiga União Soviética, associados a ambientes de margens continentais ou arcos de ilha. Jazidas cenozóicas são amplamente predominantes em número, seguidas pelas mesozóicas e finalmente as paleozóicas. Depósitos précambrianos similares têm sido descritos, mas ainda em número relativamente reduzido (e.g. Kirkham, 1972; Gaál \& Isohanni, 1979).

As rochas hospedeiras de mineralização de cobre de tipo pórfiro são, portanto, de natureza predominantemente cálcio-alcalina, colocadas em ambientes rasos, epizonais, que apresentam grande variabilidade composicional, desde máficas até félsicas. Em geral, a mineralização é mais comum nos termos félsicos, que apresentam estruturas em geral maciças e texturas porfiríticas a equigranulares.

As características geométricas destas jazidas são também típicas: em planta distribuem-se de forma subcircular a elongada e, em profundidade, apresentam formas tubulares, em funil ou mais raramente tabulares. Em superfície, a área economicamente mineralizada pode alcançar ca. $4 \mathrm{~km}^{2}$ (e.g., Bingham, Utah), mas muitas vezes as dimensões verticais são bem superiores as horizontais, fazendo com que a exploração seja limitada.

Os primeiros estudos de jazidas de $\mathrm{Cu}$ de tipo pórfiro, até então denominadas de jazidas de "Cobre disseminado", foram feitos nos Estados Unidos e foram baseados essencialmente em 
observações geológicas, estruturais e petrográficas. Parsons (1933) utilizou o termo "porphyry copper" ("cobre de tipo pórfiro") para descrever este tipo de depósito, caracterizado pela mineralização muito dispersa. Smith (1966) definiu as jazidas de "pórfiro de cobre" como depósitos de cobre massivo de baixo teor, sem considerar sua gênese ou o tipo de rocha hospedeira. De acordo com este autor, uma jazida deste tipo deveria conter reservas superiores a cinco milhões de toneladas e teores inferiores a $2 \%$ (em peso) de $\mathrm{Cu}$.

De acordo com Lowell \& Guilbert (1970), os depósitos de tipo pórfiro seriam aquelas jazidas de sulfetos de $\mathrm{Cu} \pm$ Mo que apresentam mineralização disseminada ou em finos veios entrecruzados, "stockworks", distribuídos em uma variedade de rochas ígneas hospedeiras, as quais foram alteradas hidrotermalmente de acordo com um padrão de zonamento bem definido. Segundo Titley \& Beane (1981), estes depósitos resultariam da implantação e evolução de importantes sistemas hidrotermais estabelecidos imediatamente após a colocação das rochas intrusivas em ambientes relativamente rasos. Estes sistemas seriam responsáveis pela dispersão da mineralização a partir de plutons relativamente pequenos, originando grandes volumes de rochas alteradas e mineralizadas com baixos teores.

Atualmente, o termo combina considerações de engenharia de minas com características geológicas e descreve grandes intrusões epigenéticas com baixo teor que podem ser exploradas de forma economicamente viável. A quantidade de informações acumulada nas últimas décadas relativas às jazidas de $\mathrm{Cu}$ de tipo pórfiro foi muito significativa. Apresenta-se, a seguir, uma breve caracterização destes depósitos, baseada principalmente nos trabalhos de Lowell \& Guilbert (1970), Rose (1970), Titley (1975), Gustafson (1978), Beane \& Titley (1981), Titley \& Beane (1981) e Giggenbach (1997).

Embora o desenvolvimento deste tipo de mineralização seja geneticamente associado às intrusões epizonais de volumes relativamente reduzidos, os efeitos dos processos de alteração hidrotermal extendem-se por uma ampla área, afetando um considerável volume de rochas. Estas rochas são denominadas wall rocks (rochas encaixantes) e podem apresentar composições variadas, desde básico-intermediárias até ácidas, e ser co-magmáticas ou representar diferentes pulsos intrusivos. Brechas e enxames de diques fazem parte deste sistema.

As características comuns identificadas em diversos estudos das jazidas mais típicas conhecidas conduziram à elaboração de modelos empíricos baseados em halos característicos de alteração hidrotermal distribuídos em planta (projeção horizontal) de forma mais ou menos concêntrica.

O modelo mais simples de zonalidade hidrotermal, considera que a zona de núcleo do sistema mineralizado é caracterizada por um grau mais intenso de alteração, denominada alteração potássica, devido a desenvolver tipicamente minerais portadores de K (biotita + K-feldspato), além de quartzo. O predomínio de biotita ou de K-feldspato depende da disponibilidade de $\mathrm{Fe}$ e/ou Mg nas rochas originais ou no fluído hidrotermal, de modo que as rochas mais máficas com alteração deste tipo apresentam biotita predominante, ao contrário das rochas mais félsicas, 
onde feldspato potássico é a fase mais importante.

Esta zona hidrotermal passa para uma zona externa, em que predominam como minerais estáveis muscovita e quartzo, denominada zona de alteração fílica. Nesta zona, a muscovita ocorre em geral na variedade fina sericita, estruturalmente intermediária entre illita e muscovita. Externamente à zona fílica aparece uma zona caracterizada pela estabilidade de minerais de argila e quartzo, a zona de alteração argílica. Finalmente, a zona mais externa de alteração, caracterizada pela paragênese clorita + epidoto + carbonatos, é conhecida como zona de alteração propílica. Este halo desaparece mais ou menos progressivamente até se alcançar rochas encaixantes sãs ou muito pouco alteradas.

Um esquema geral da distribuição e da importância relativa das zonas típicas de alteração é apresentado na Figura 2.1. Modelos algo mais complexos consideram duas zonas distintas de alteração potássica, uma delas denominada potássica profunda, caracterizada pela presença de K-feldspato e sericita com mineralização fraca, onde a magnetita é mais abundante que calcopirita e pirita. De acordo com Carten (1986) e Dilles \& Einaudi (1992), existe também uma zona de alteração sódico-cálcica situada na parte mais profunda, próxima à zona propílica, caracterizada pela presença de actinolita e plagioclásio sódico (oligoclásio). Naturalmente, estas zonas não necessariamente se desenvolvem em todas as jazidas de $\mathrm{Cu}$ do tipo pórfiro.

Nos depósitos mais típicos, a mineralização apresenta um núcleo de baixo teor que grada para uma zona mineralizada (Figura 2.2). Nesta zona interna ocorre pirita disseminada e/ou em veios com calcopirita subordinada e molibdenita. Uma zona de pirita que grada para a rocha sã é freqüente nas porções periféricas dos depósitos. Freqüentemente a região mineralizada situa-se na zona marginal de alteração potássica, estendendo-se para a zona fílica. O setor mais interno apresenta maior proporção de sulfetos portadores de cobre como a bornita que grada para uma zona em que a calcopirita passa a ser mais importante, seguida por zonas externas em que a pirita é amplamente dominante (Figura 2.2). Não existe limite físico para o corpo mineralizado; o limite de uma jazida deste tipo é fixado em termos econômicos, baseados nos teores mínimos de corte.

Processos supérgenos, envolvendo principalmente oxidação e lixiviação, são importantes em muitas jazidas e resultam em significativo enriquecimento secundário de $\mathrm{Cu}$. Os sulfetos primários, pirita e calcopirita, em condições atmosféricas são oxidados e dissolvidos por águas superficiais originando ácido sulfúrico e sulfatos de cobre e ferro. O clima, a proporção relativa pirita:calcopirita e a presença de agentes neutralizantes podem concentrar e reter o cobre em superfície na forma de carbonatos, silicatos ou sulfatos, e mesmo limonitas, esta concentrando a maior parte do ferro lixiviado.

A migração lateral e subsuperficial do ácido sulfúrico e do sulfato de cobre em ambiente redutor, com presença de sulfetos primários, conduzem à formação de calcosita, digenita e bornita no nível freático ou abaixo dele. Estes minerais apresentam conteúdo bem superior de cobre quando comparados com calcopirita e, por isso, esta zona é denominada como zona de 


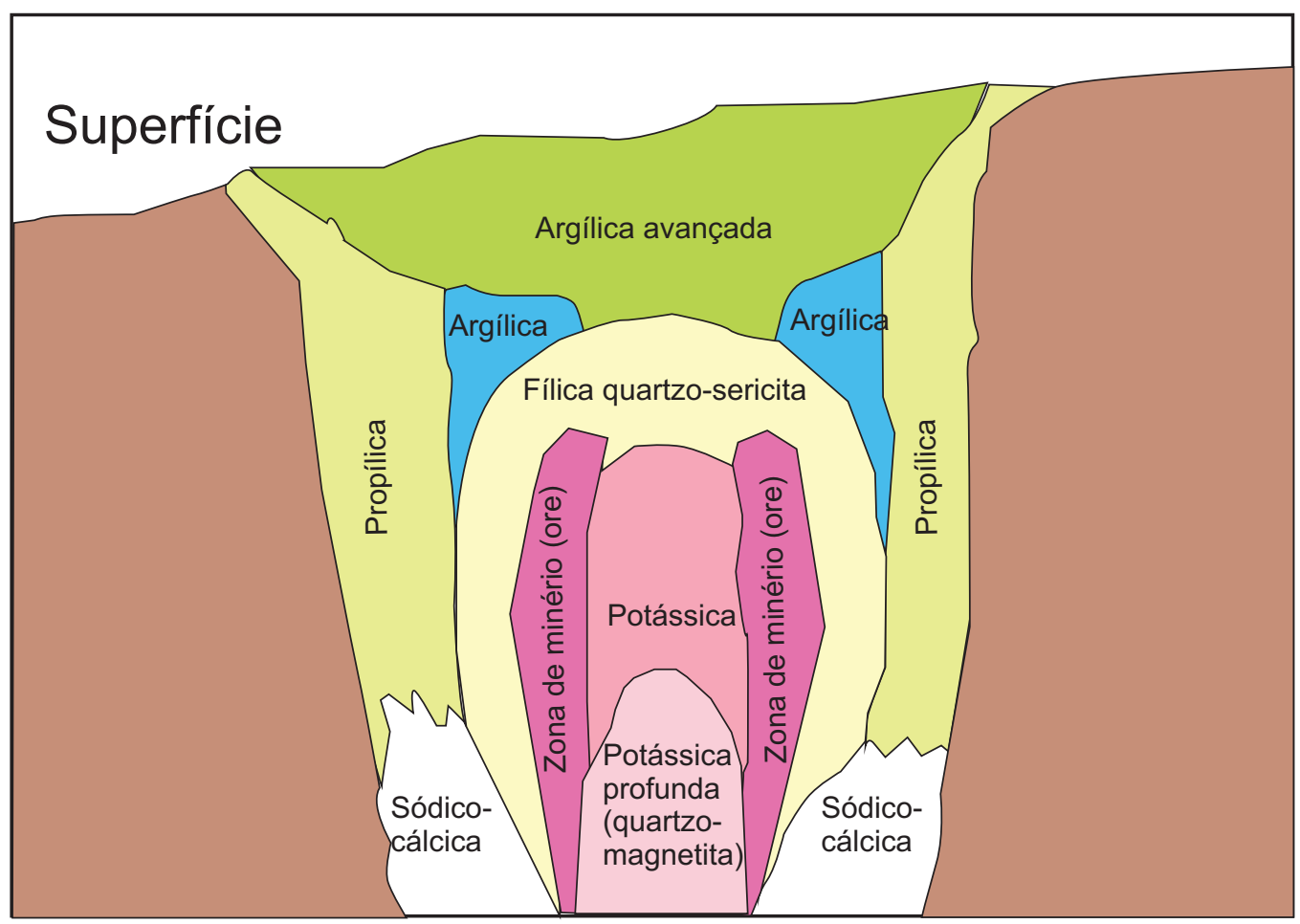

Figura 2.1: Distribuição das zonas de alteração hidrotermal em uma jazida de Cu do tipo pórfiro, combinando os modelos de Lowell \& Guilbert (1970), Gustafson \& Hunt (1975), Giggenbach (1997), de acordo com Maksaev (2001).

enriquecimento secundário.

A oxidação supérgena não conduz necessariamente ao enriquecimento secundário, mas com certeza é um pré-requisito para sua formação. Fatores fundamentais, que controlam os processos de oxidação e o enriquecimento secundário são a velocidade de erosão, deformação, tempo, tipo de rocha, clima e mudança do nível freático (Blanchart, 1968). Estes processos supérgenos resultam em um zoneamento típico, superposto aos halos de alteração hidrotermal, tal como ilustrado na Figura 2.3.

\subsection{As jazidas de $\mathrm{Cu}$ de tipo pórfiro no Perú}

O Perú possui um número significativo de jazidas de $\mathrm{Cu}$ de tipo pórfiro, as quais sempre tiveram enorme influência na economia do país. A maioria das jazidas encontra-se no flanco ocidental da Cadeia Andina, constituída por três unidades geológicas maiores: o Maciço de Arequipa, o "Geossinclinal" Mesozóico (seqüência vulcano-sedimentar) e o Batólito Costeiro do Perú, ou simplesmente Batólito Costeiro (Figura 2.4).

O Batólito Costeiro é a unidade de maior interesse econômico e se caracteriza por apresentar variações significativas no que se refere à diversidade e à abundância de depósitos metálicos. De acordo com Pitcher \& Cobbing (1985), a evolução metalogenética na zona batolítica pode ser descrita segundo três etapas bem contrastadas do magmatismo. 


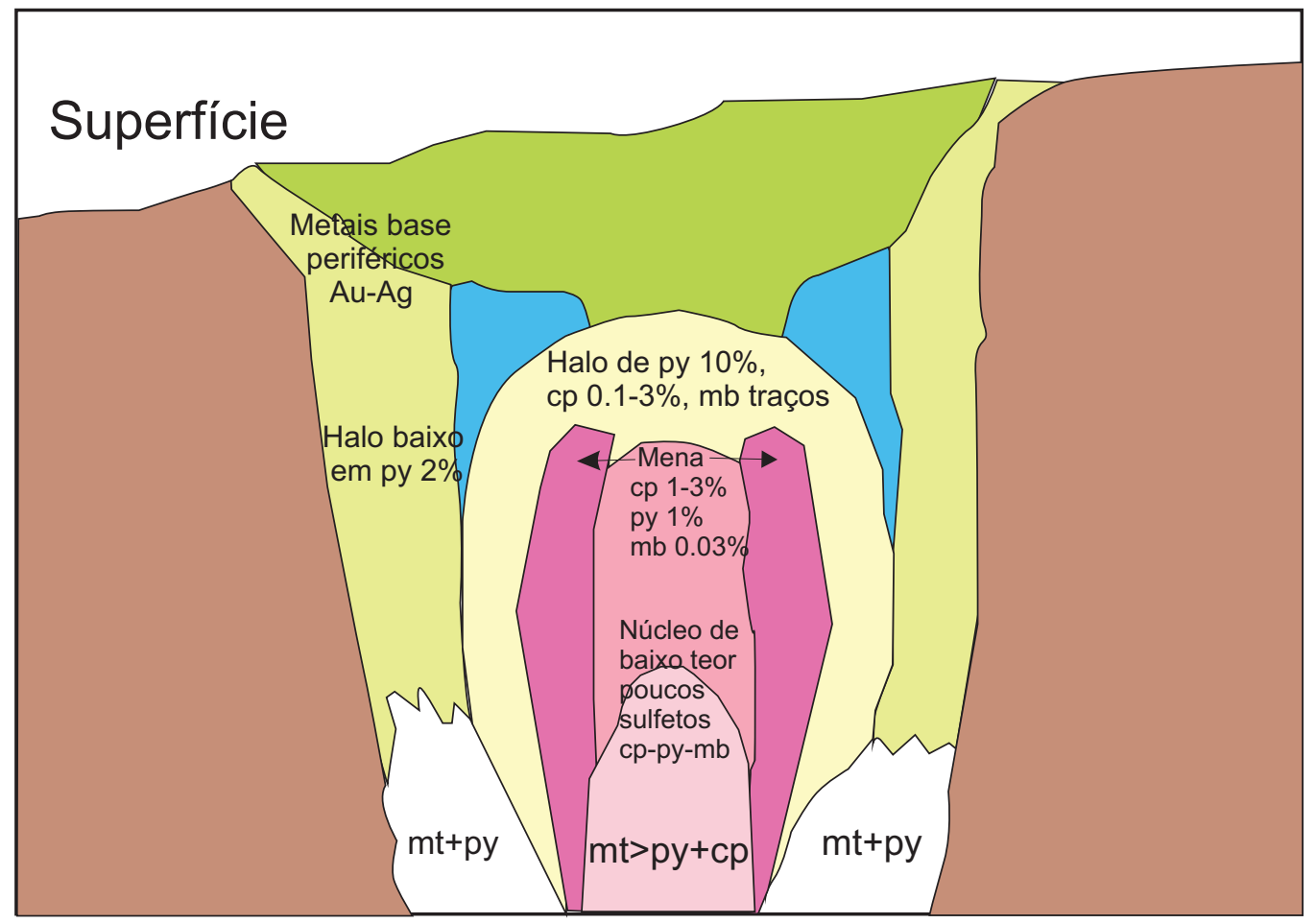

Figura 2.2: Distribuição de minerais da zona mineralizada em um típico depósito de pórfiro de Cobre. py $=$ pirita, $\mathrm{cp}=$ calcopirita, $\mathrm{mb}=$ molibdenita, $\mathrm{mt}=$ magnetita., de acordo com Maksaev (2001).

A primeira etapa, denominada pré-batolítica, está representada pelas rochas intrusivas gabróides e relacionada com depósitos de barita-Zn e de $\mathrm{Cu}-\mathrm{Fe}$, de natureza metassomática. Um segundo evento magmático, o mais importante do Batólito Costeiro, se relaciona ao desenvolvimento de veios de $\mathrm{Cu}-\mathrm{Mo}$, skarns de $\mathrm{Cu}-\mathrm{Mo}-\mathrm{W}$ e ocorrências de $\mathrm{Cu}-\mathrm{Mo}$ e Fe de tipo pórfiro. Este evento está melhor marcado nos segmentos Arequipa e Toquepala (Figura 2.4), particularmente no primeiro. O terceiro evento envolve a formação das clássicas jazidas de $\mathrm{Cu}-\mathrm{Mo}$ do tipo pórfiro associadas com stocks hipoabissais mais tardios e/ou pós-batolíticos.

Assim, as principais jazidas de $\mathrm{Cu}$ de tipo pórfiro estão relacionadas aos períodos batolítico e pós-batolítico. No Perú as intrusões mineralizadas ocorrem na forma de stocks e diques que apresentam idades no intervalo entre 60 (jazidas do Sul) e 8 Ma (Jazida Toromocho, $c f$. Figura 2.5). Petrograficamente, as rochas predominantes correspondem a quartzo monzonitos e dacitos relacionados às intrusões principais de tonalito-granodiorito (Muñoz, 1980).

A distribuição geográfica das jazidas de $\mathrm{Cu}$ de tipo pórfiro no Peru é ilustrada na Figura 2.5. De forma geral, estas ocorrências estão localizadas segundo lineamentos ou faixas subparalelos ao Batólito Costeiro, embora algumas ocorrências pós-batolíticas estejam associadas mais de perto ao Batólito Cordilheira Branca (e.g., Aguila, Compaccha, Califórnia e Jacabamba, estes dois últimos de Mo-W, cf. Figura 2.5) e outras, como Michiquillay, Granja e Cañariaco pareçam estar vinculadas ao Batólito Pomahuaca, que se estende até o Equador.

No clássico trabalho versando sobre os depósitos de $\mathrm{Cu}$ de tipo pórfiro peruanos, Muñoz 


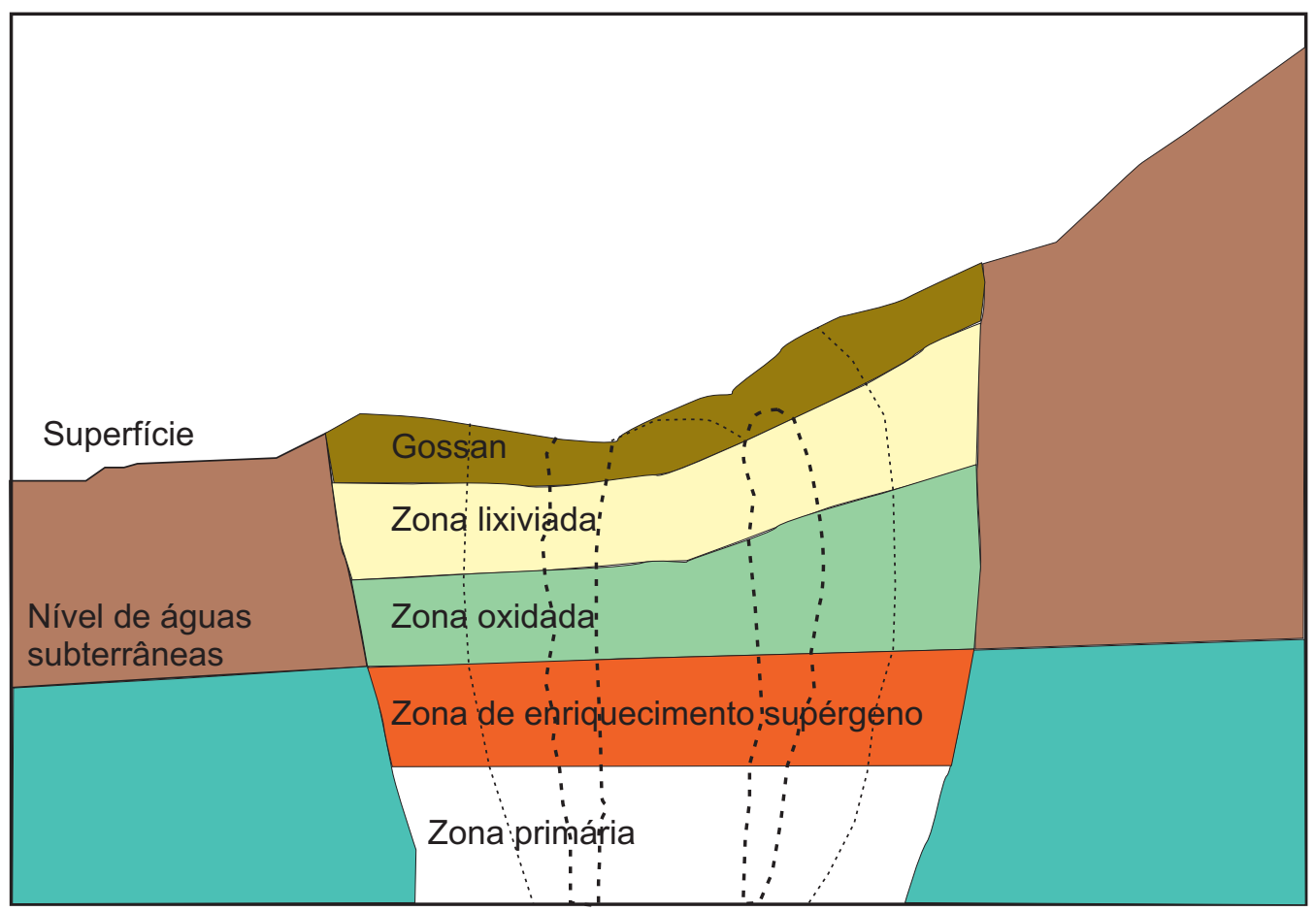

Figura 2.3: Zoneamento produzido por efeitos supérgenos em uma jazida de $\mathrm{Cu}$ do tipo pórfiro. De cima para baixo: Gossam ou chapéu de ferro, caracterizado por óxidos e hidróxidos de ferro; zona lixiviada, com conteúdo escasso de metais; zona oxidada, com concentração de minerais oxidados de cobre (crisocola, atacamita, malaquita); zona de enriquecimento supérgeno, caracterizada pela concentração de sulfetos secundários de $\mathrm{Cu}$ (calcosina, covelina, digenita, bornita); zona primária ou hipógena não afetada, com sulfetos primários (pirita, calcopirita, bornita). Segundo Maksaev (2001).

(1980) conclui que existem cinco variações principais nos padrões de alteração hidrotermal e observa que algumas zonas hidrotermais típicas não se desenvolveram em todos os depósitos ou provavelmente não afloram no nível atual de erosão. São elas:

1. Zonas de alteração potássica, fílica e propílica: Cerro Verde, Quellaveco, Sta Rosa, Almacen, El Aguila Cañariaco e Toro Mocho.

2. Zonas de alteração fílica e propílica, esta última de grande extensão: Toquepala, Cuajone, La Huaca, Soccos e Pashpap.

3. Zonas de alteração potássica, fílica, argilica e propílica: Michiquillay, Compaccha, El Aguila.

4. Zonas de alteração potássica e propílica: Almacen.

5. Zonas de alteração potássica, silificação argílica e propílica: El Molino.

Canchaya (1993) apresenta um resumo das características mais importantes (localização, alteração hidrotermal, mineralização hipógena, enriquecimento secundário e reservas) das principais jazidas peruanas. Segundo este autor, a mineralogía primária é composta por pirita, 


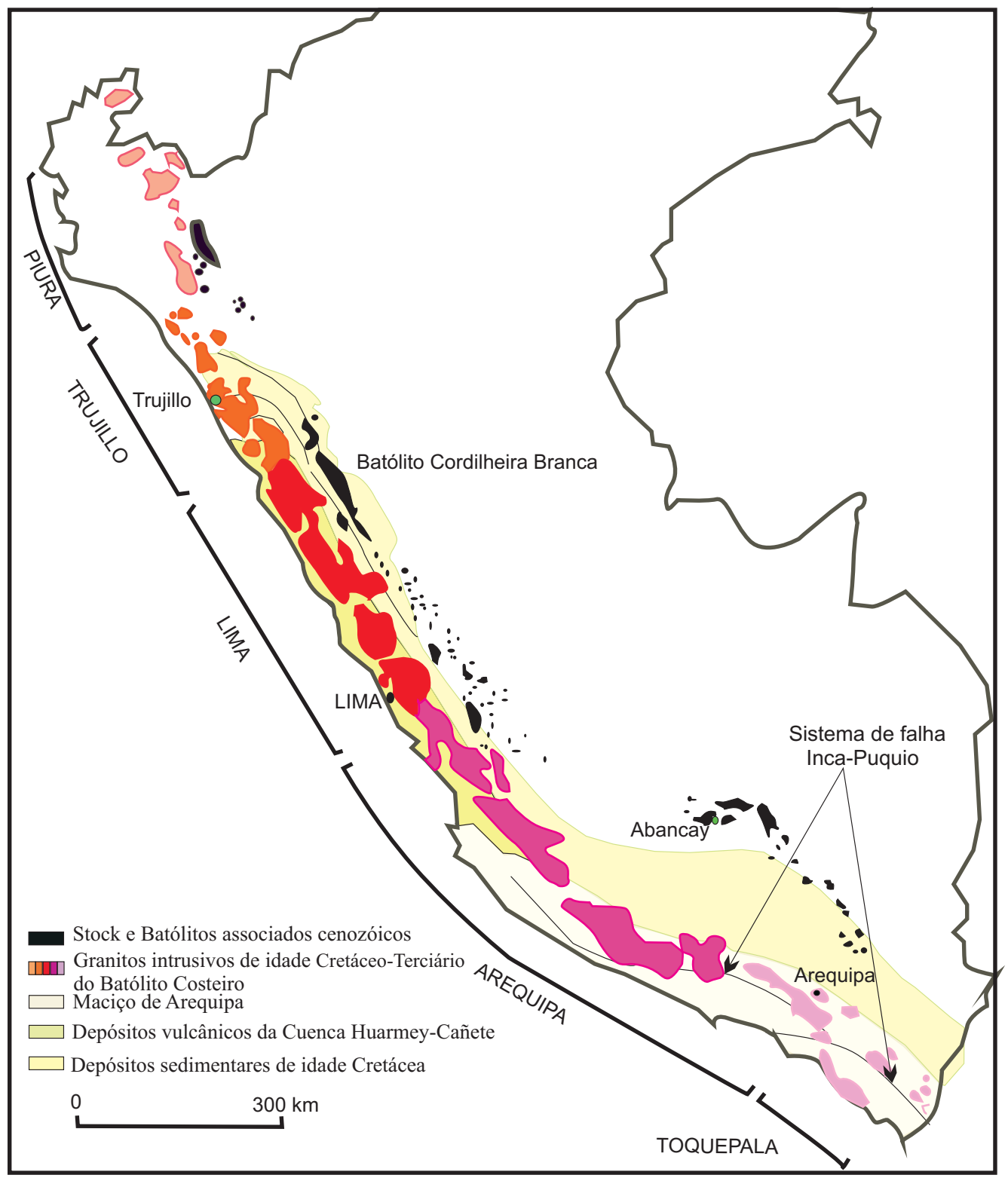

Figura 2.4: Principais unidades geológicas e segmentação do Batólito Costeiro do Perú. Modificado de Pitcher \& Cobbing (1985) e Cobbing (1998).

calcopirita, molibdenita, cobre cinza, enargita, covelita, bornita, magnetita, rutilo e escassa galena, esfalerita, pirrotita, cubanita e mackinawita, enquanto na secundária ocorrem calcosita, covelita e bornita, e na zona de oxidação aparece crisocola, brocantita, cuprita, tenorita, cobre nativo e óxidos de Fe e Mn.

Na Tabela do Anexo 2 apresenta-se uma compilação das principais características destas jazidas, de acordo com os trabalhos de Muñoz (1980) e Singer (2005). Informações adicionais são encontradas em Aguilar et al. (1974). 


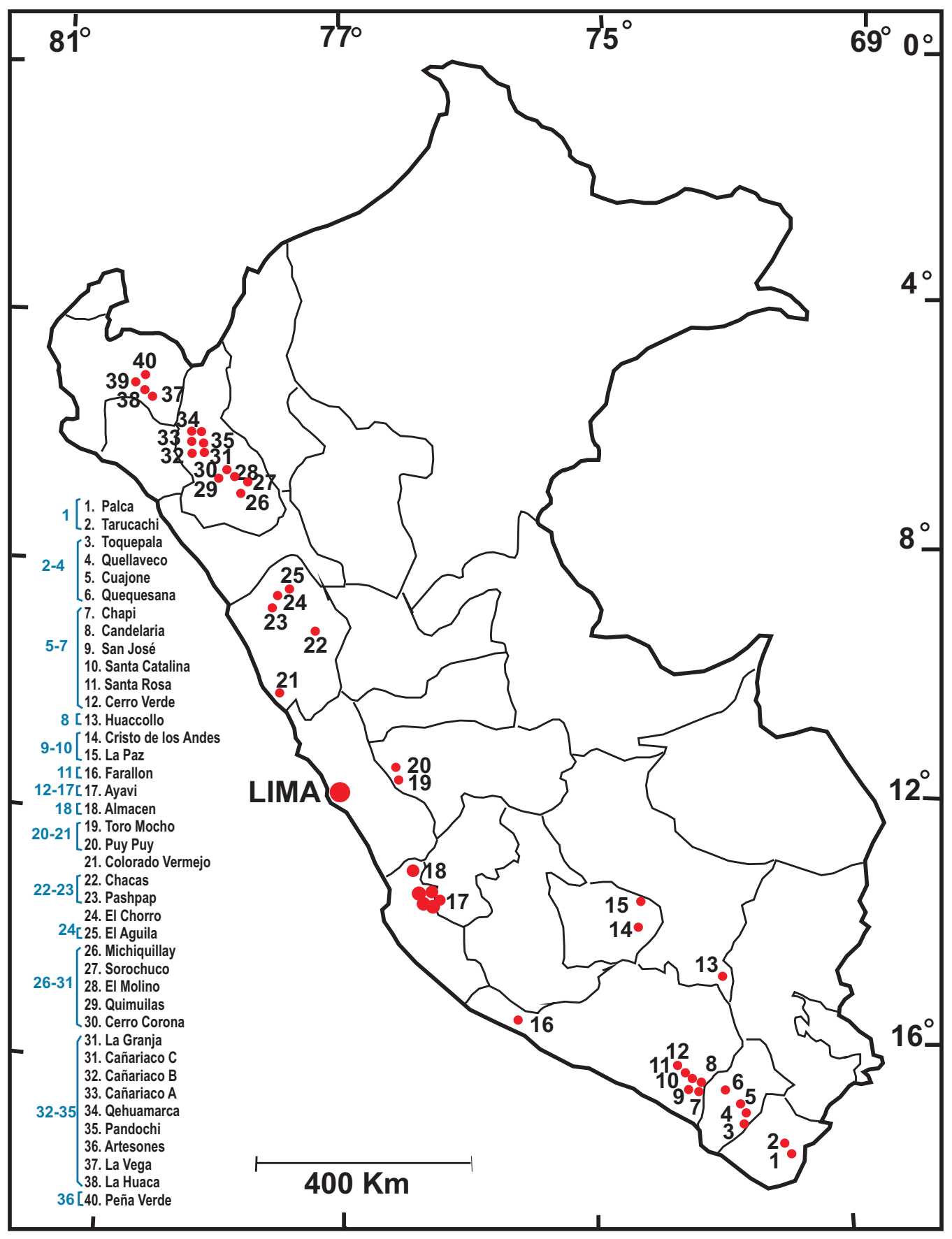

Figura 2.5: Distribuição regional das jazidas de $\mathrm{Cu}$ do tipo pórfiro no Perú. Aguilar et al. (1974) reconhece um total de 40 depósitos (em vermelho), enquanto Singer (2005) os agrupa em 36 ocorrências (em azul). Os nomes utilizados pelo último autor são referidos no Anexo 2. 


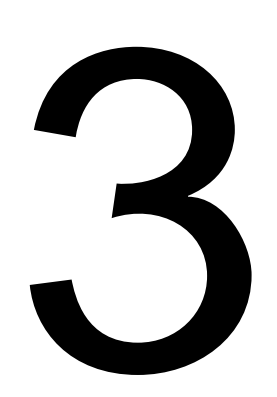

\section{A jazida de Cuajone}

\subsection{Aspectos fisiográficos e geomorfológicos}

\subsubsection{Relevo}

A região de Cuajone encontra-se em altitudes de 3100 a 3830 m e é caracterizada por uma topografia muito acidentada, em que aparecem numerosas depressões profundas e pouco largas, denominadas quebradas, e vales estreitos, em meio a cadeia de montanhas. Entre as depressões mais importantes se tem o vale do rio Torata ao norte da jazida de Cuajone de direção NW-SE e com $500 \mathrm{~m}$ de profundidade e a antiga quebrada Chuntacala de direção E-W que corta a parte central da jazida e se dirige ao rio Torata.

\subsubsection{Clima}

O clima predominante na região é seco. As temperaturas mais elevadas ocorrem nos meses de setembro, outubro e novembro, obervando-se valores máximos em torno de $17{ }^{\circ} \mathrm{C}$ e mínimos de $4{ }^{\circ} \mathrm{C}$. Nos meses de junho, julho e agosto, as temperaturas são mais baixas e variam no intervalo entre 14 e $2{ }^{\circ} \mathrm{C}$. O período chuvoso vai de dezembro a março durante os quais as precipitações são contínuas e persistentes e quase sempre acompanhadas de neblina densa.

\subsubsection{Unidades geomorfológicas regionais}

As unidades geomorfológicas regionais de relevância para a região de Cuajone (Figura 3.1) são definidas e descritas por Bellido (1979), Clark et al. (1990b), Chacón (1995), INGEMMET 


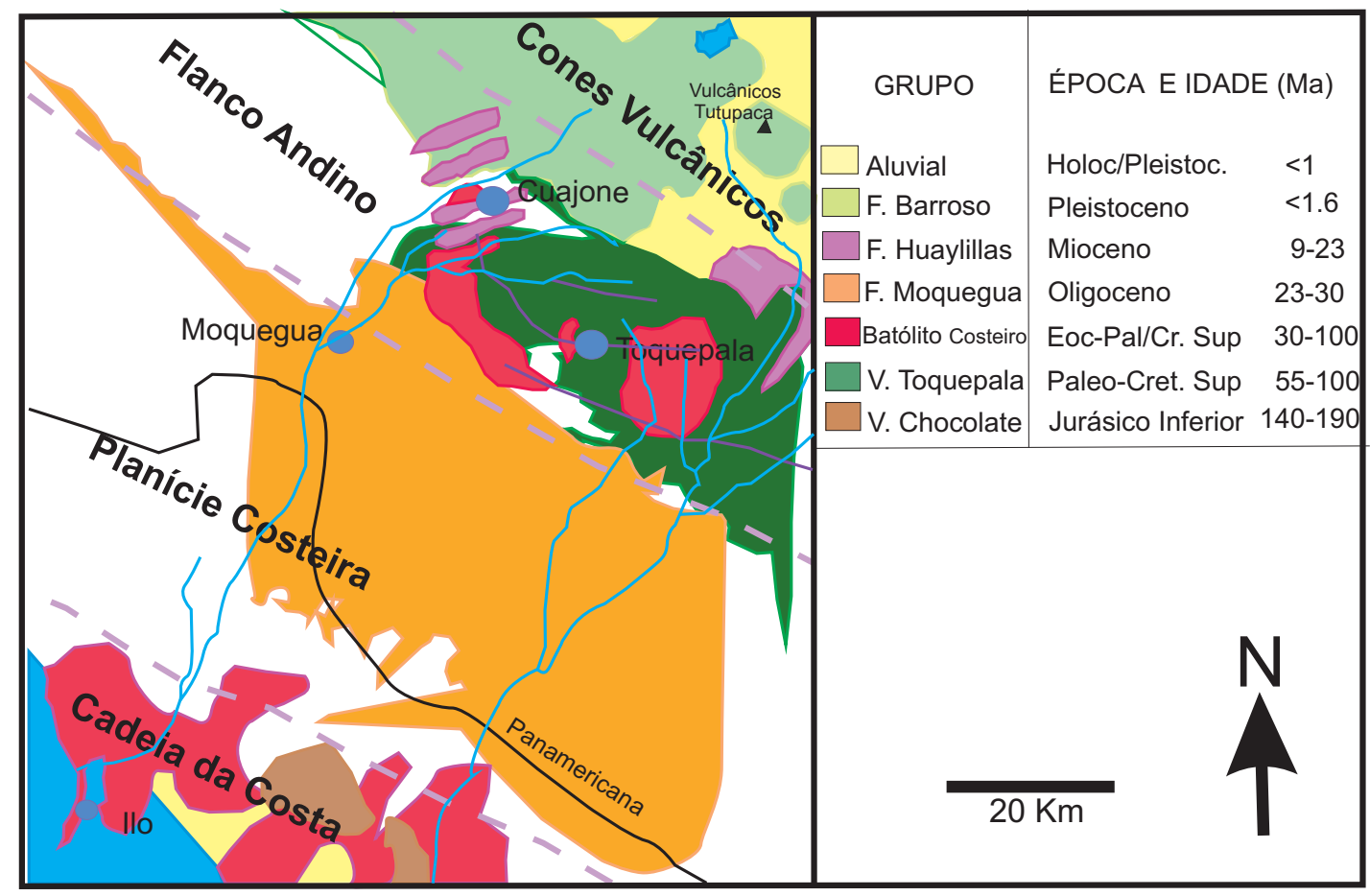

Figura 3.1: Principais unidades geomorfológicas regionais, segundo Clark et al. (1990b).

(2000). A seguir apresenta-se uma breve síntese de suas características, fundamentada nestes trabalhos.

\section{Cadeia da Costa}

Esta unidade geomorfológica aparece a SW e constitui uma feição geomorfológica reliquiar de uma antiga cadeia que evidencia processos magmáticos, tectônicos e de metamorfismo regional ocorridos durante o Proterozóico. Encontra-se segmentada e distribue-se de forma subparalela ao litoral pacífico, com orientação NW-SE. A Cadeia da Costa alcança altitudes aproximadas entre 900 e $1200 \mathrm{~m}$ acima do nível do mar.

\section{Planície Costeira}

Esta unidade ocorre entre a Cadeia da Costa e o Flanco Andino (Figura 3.1). Corresponde a uma faixa costeira de 20 a $100 \mathrm{~km}$ de largura, orientada na direção NW-SE, na qual o relevo é moderado, com altitudes entre 50 e 1500 m e o clima é tipicamente desértico. Caracterizase também por apresentar diversas depressões profundas com direção NE-SW. Na área da região Cuajone, afloram, nesta unidade, sedimentos clásticos continentais semi-consolidados pertencentes à Fomação Moquegua do Eoceno-Oligoceno (Terciário Superior).

\section{Flanco Andino}

O Flanco Andino, com direção NE, apresenta relevo escarpado e dissecado. O limite com a planície costeira é bem marcado, passando-se de uma topografia suave para um relevo muito 
abrupto com altitudes entre 3100 a $3400 \mathrm{~m}$. Nesta zona afloram essencialmente rochas intrusivas e vulcânicas as quais, na área de estudo, correspondem às rochas vulcânicas Toquepala e parte do do Batólito Costeiro, onde se situam as jazidas de Cuajone, Toquepala e Quellaveco.

\section{Cadeia de Cones Vulcânicos}

Esta unidade aparece no extremo NE da região e é formada por uma sucessão de cones vulcânicos. Apresenta uma largura de aproximadamente 20 a $30 \mathrm{~km}$ e orienta-se na direção NW-SE, com altitudes elevadas, que atingem máximos de $5.815 \mathrm{~m}$., como no caso do vulcão Tutupaca ( $c f$. Figura 3.1). Na área de estudo, a Formação Barroso faz parte desta unidade.

\subsection{Geologia da Região de Cuajone}

\subsubsection{Unidades Geológicas}

As principais unidades geológicas e sua estratigrafia são ilustradas na Figura 3.1 e brevemente descritas a seguir, em ordem estratigráfica.

\section{Formação Chocolate}

A formação Chocolate foi definida por Jenks (1946) e data do Jurássico Inferior. Corresponde uma seqüência vulcanossedimentar, caracterizada pela alternância de derrames de brechas de composição andesítica com camadas de calcários de colorações tipicamanente amarronzadas.

\section{Grupo Toquepala}

O Grupo Toquepala (Bellido \& Guevara, 1963) é composto por rochas vulcânicas e vulcanoclásticas intercaladas com conglomerados e arenitos. Apresenta idades entre o Cretáceo Superior ao Terciário Inferior e aflora ao largo do Flanco Andino. As rochas deste grupo foram datadas por Bellón \& Lefevre (1976) em $59 \pm 3$ Ma com o método Rb-Sr em rocha total. As unidades superiores (Paralaque e Quellaveco) deste grupo encontram-se presentes nas áreas das minas Cuajone, Toquepala e Quellaveco.

Este grupo foi dividido na região em quatro formações por Bellido \& Landa (1965) e Bellido (1979). Assim, da base para o topo deste grupo teríamos: a Formação Toquepala (Wilson \& García, 1962) composta por rochas vulcânicas andesíticas e riolíticas, a Formação Inogoya, formada por conglomerados e arenitos tufáceos e calcáreos, a Formação Paralaque, constituída por rochas vulcânicas riolíticas, dacíticas e andesíticas e finalmente a Formação Quellaveco, em que aparecem rochas vulcânicas e piroclásticas de composições riolíticas, dacíticas e andesíticas.

\section{Formação Moquegua}

A Formação Moquegua (Bellido \& Guevara, 1963; Tosdal et al., 1981; Marocco \& Noblet, 1990) é composta essencialmente por rochas sedimentares (argilitos, arenitos, conglomerados) 
acompanhadas de arenitos tufáceos e tufos. Esta formação aflora entre as unidades da Cadeia Costeira e do Flanco Andino e a sua origem é atribuída a um período de erosão e deposição no Terciário Médio (Tosdal et al., 1984).

\section{Formações Huaylillas e Chuntacala}

As Formações Huaylillas (Wilson \& García, 1962) do Mioceno Inferior (Tosdal et al., 1981) e Chuntacala (Manrique \& Plazolles, 1975) do Mioceno Médio (Tosdal et al., 1981; Sébrier et al., 1983) são constituídas por tufos e aglomerados de composições andesíticas, traquíticas e riolíticas. Aparecem cobrindo a Formação Moquegua e o Grupo Toquepala (Figura 3.1).

\section{Formação Capillune}

A Formação Capillune, do Plioceno Superior (Mendivil, 1965), é composta por uma seqüência de rochas sedimentares (arenitos, argilitos) e vulcânicas piroclásticas que cobrem extensas áreas na Cordillera Ocidental. Sobrepõem-se discordantemente à Formação Huaylillas e Chuntacala. Tosdal et al. (1981) apresentam idades K/Ar, obtidas em cristais de plagioclásio, entre 7,0 土 0,4 Ma. e 3,3 \pm 0,1 Ma, equivalentes ao Mioceno Superior.

\section{Formação Barroso}

A Formação Barroso (Wilson \& García, 1962) do Plioceno Inferior a Pleistoceno (Mendivil, 1965; Tosdal et al., 1981) corresponde principalmente à Cadeia de Cones Vulcânicos ou Cordilheira dos Andes e é composta por tufos e lavas de composição andesito-dacíticos e traquíticos.

\section{Depósitos Aluvionais}

Constituem-se de depósitos aluvionares, coluvionares e fluviais de piedemonte e apresentam composições diversas. Ocorrem principalmente nos leitos dos rios e nas vertentes inferiores das serras.

\subsubsection{Rochas Intrusivas}

\section{Batólito Costeiro}

O Batólito Costeiro corresponde a um complexo múltiplo de rochas intrusivas. É composto essencialmente por tonalitos e granodioritos que ocupam o núcleo da Cordilheira Ocidental, com uma extensão de cerca de 1,600 km na direção NW - SE e mais de 65 km de largura média. Considerando-se os plutons isolados que se estendem desde o Chile ao Equador, a sua extensão alcança 2,400 km (Sanchez \& León, 1995).

O Batólito Costeiro foi subdividido estruturalmente por Cobbing \& Pitcher (1972b) em quatro segmentos, denominados Piura, Trujillo, Lima e Arequipa. Pitcher et al. (1985) incluíram os plutons que são expostos nas regiões das minas Toquepala, Quellaveco e Cuajone dentro do Segmento Toquepala. 
Segundo Pitcher (1974), a ordem de colocação das rochas intruvisas nos diferentes segmentos do Batólito, permite reconhecer duas seqüências ("ritmos") de tipo básico-ácido. A seqüência principal, mais antiga, teria originado as ocorrências mais expressivas de gabros, dioritos e quartzo dioritos; a segunda seqüência, mais jovem seria marcada pela intrusão de tonalitos, granodioritos e granitos.

Na região central, as rochas do Batólito apresentam idades entre $76 \pm 3 \mathrm{Ma}$ e $33 \pm 1 \mathrm{Ma}$, embora o intervalo total do magmatimo registrado seja da ordem de $102 \pm 26$ Ma (Stewart \& Snelling, 1971).

As intrusões com idades entre 50 e 60 Ma são as principais responsáveis pela mineralização de $\mathrm{Cu}$ de tipo pórfiro, como se comprova nas jazidas de Toquepala, Quellaveco, Cuajone e Cerro Verde. Nas regiões das jazidas de Toquepala e Cuajone, estes plútons (stocks) invadem todos os membros dos Vulcânicos Paralaque e Quellaveco do Grupo Toquepala (Zweng \& Clark, 1995).

\subsubsection{Estruturas Regionais}

O relevo do território peruano é o resultado de sucessivos ciclos tectônicos, abrangendo etapas de sedimentação, deformação, soerguimentos e finalmente de erosão e desenvolvimento de peneplanícies.

O Ciclo Andino, bem marcado nas rochas mesozóicas e cenozóicas agrupa várias fases de sedimentação e deformação, sendo as principais denominadas Fase Peruana (Cretáceo superior), Fase Inca (Terciário inferior) e, finalmente, a Fase Quechua (Terciário médio a superior).

A fase Peruana foi essencialmente compressiva e gerou dobramentos regionais, falhamentos e fraturamentos. Nesta fase se teve a colocação da parte mais significativa dos diferentes pulsos magmáticos que construiram o Batólito Costeiro.

A fase Inca, segundo Steinmann (1929), foi a fase mais importante do Ciclo Andino devido a sua extensão e efeitos produzidos. De caráter fortemente compressivo, gerou dobras, falhas inversas e nappes. O vulcanismo generalizado na região da Cordilheira Ocidental, ocorreu após esta fase.

A fase Quechua é dividida em três sub-fases Palacios (1995): Quechua 1, compressiva, acompanhada por falhamentos, soerguimentos e erosão, responsável pela superfície Puna e, a seguir, vulcanismo explosivo para Sul (Vulcânicos da Formação Huaylillas). As fases Quechua 2 e 3 estão associadas a soerguimento, falhamentos e atividades vulcânicas mais tardias.

As grandes estruturas regionais na região Sul do Perú, se orientam predominantemente NW-SE e são caracterizadas pelo extenso sistema de falhas Incapuquio, do qual a zona de falha mais importante é a própia zona de falha Incapuquio.

Esta zona de falha pode ser acompanhada por cerca de $140 \mathrm{~km}$, desde a fronteira com o Chile, passando pelo estado de Tacna e parte do estado do Moquegua (Barúa, 1961; Wil- 
son \& García, 1962). As características cinemáticas desta falha e suas variações no tempo geológico não estão ainda bem definidas ao longo de toda a sua extenção, e movimentos de tipo trancorrente sinistral, normal (com abatimento do lado SW) e dextrais reversos têm sido identificados por Wilson \& García (1962), Stevenson \& Damiani (1968) e Marocco \& Noblet (1990), respectivamente.

Outra estrutura importante é a zona de falha Micalaco, relacionada por Stevenson \& Damiani (1968) ao sistema de falhas Incapuquio. Apresenta cerca de $21 \mathrm{~km}$ de extensão conhecida, aflora próxima à mina Toquepala e tem movimento principal de tipo normal.

De acordo com Wilson \& García (1962) e Tosdal et al. (1981) o principal movimento do sistema de falha Incapuquio foi posterior à Fase Peruana e anterior à Fase Quechua.

\subsection{Geologia Local da Jazida de Cuajone}

Até o presente são poucos os trabalhos publicados na literatura que tratam especificamente da jazida de Cuajone, entre os quais de destacam os de Lacy (1958), Barúa (1961), Nassau (1978), Manrique \& Plazolles (1975), Torpoco (1979), Satchwell (1983) e Clark et al. (1990b). Informações mais recentes encontram-se apenas em relatórios internos do Departamento de Geologia da unidade mineira de Cuajone. Apresenta-se a seguir uma breve descrição da geologia da jazida, baseada principalmente nestes trabalhos e no relatório interno de Concha \& Bernabé (1999), fornecido pela Southern Peru Corporation.

De forma simples, a região é caracterizada pela ocorrência, na base, dos derrames vulcânicos cretácicos do Grupo Toquepala, que são invadidos pelo complexo intrusivo associado à mineralização, todo o conjunto sendo coberto pelos fluxos vulcânicos mais recentes das Formações Huaylillas e Chuncatala (Figuras 3.2 e 3.3). As rochas destas unidades têm sido, por conveniência e simplicidades, classificadas em rochas pré-mineralização, mineralizadas e pós-mineralização, como se descreve a seguir.

\subsubsection{Rochas Pré-mineralização}

São as rochas mais antigas que afloram na área, pertencentes ao Grupo Toquepala com idades entre 70 e 59 Ma (Bellido \& Guevara, 1963; Bellón \& Lefevre, 1976) e incluem essencialmente andesitos basálticos, riolitos e "doleritos".

\section{Andesitos basálticos}

Andesitos basálticos constituem a unidade basal da seqüência vulcânica. São rochas com estruturas maciças, colorações cinza-esverdeadas a pretas e texturas faneríticas inequigranulares de granulação fina ou porfiríticas com matriz inequigranular holocristalina fina. Sondagens realizadas na área indicam que estas rochas ocorrem por uma espessura superior a $800 \mathrm{~m}$, não se alcançando ainda os seus contatos inferiores (Concha \& Bernabé, 1999). 


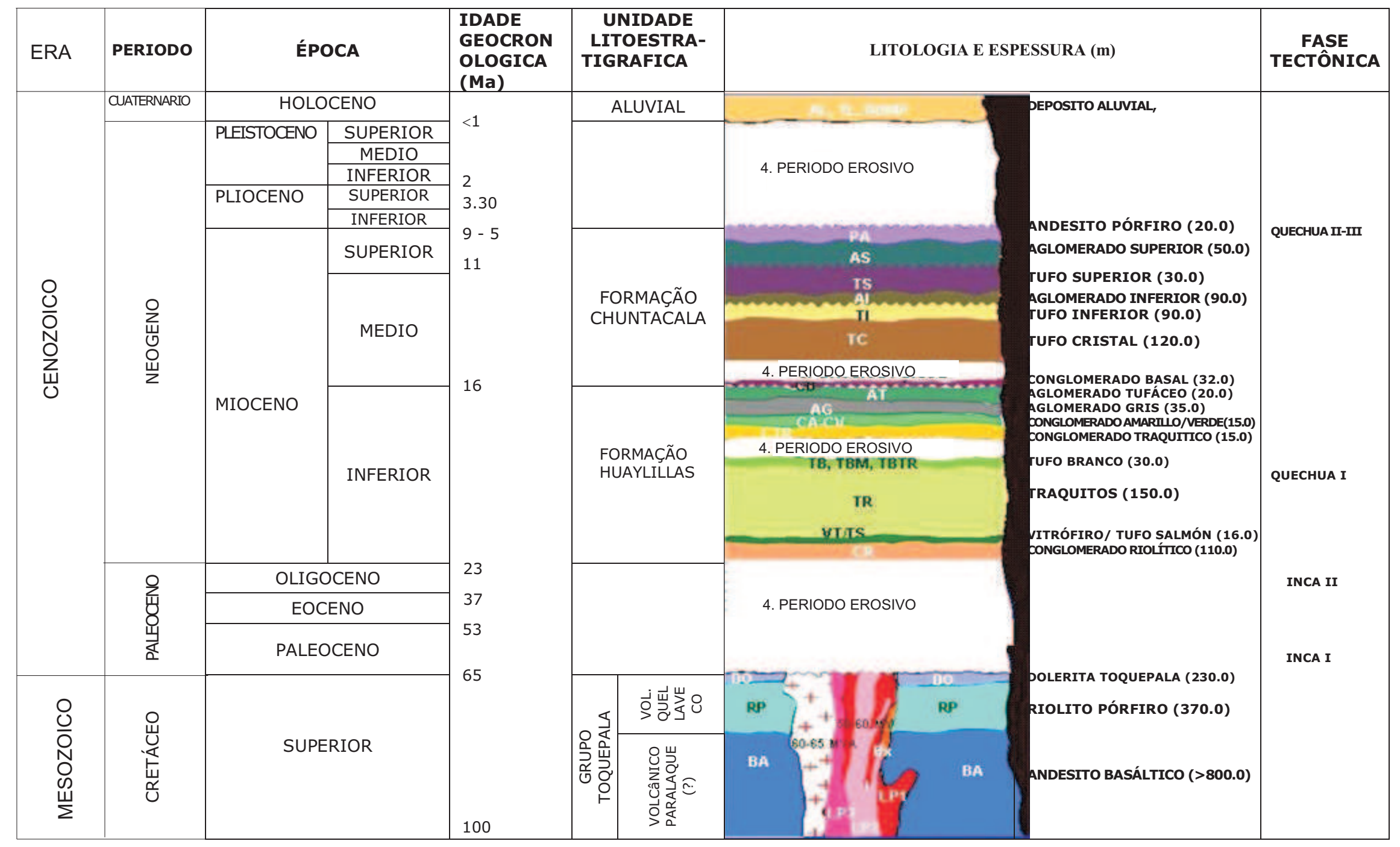

Figura 3.2: Coluna Estratigráfica da mina Cuajone, de acordo com Concha \& Bernabé (1999). 


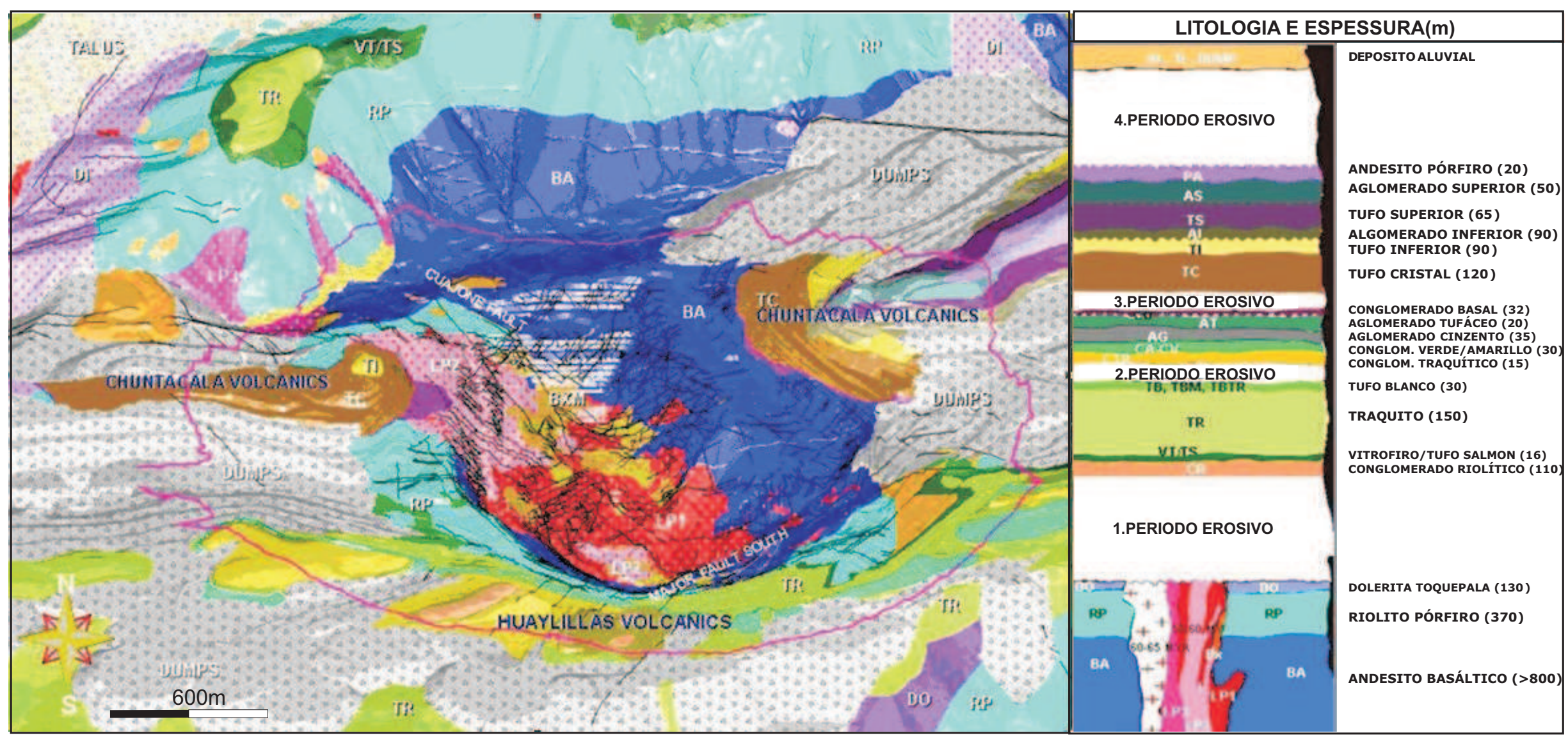

Figura 3.3: Geologia Local da mina Cuajone, de acordo com Concha \& Bernabé (1999). 
As variações de cor e da textura destas rochas geraram diversas confusões para a sua classificação, baseada inicialmente apenas em trabalhos de campo e observações macroscópicas. Assim, Manrique \& Plazolles (1975) descreveram basaltos na base do pacote, seguidos por andesitos no topo e Satchwell (1983) dividiu as rochas andesíticas em dois tipos: basálticas e "intrusivas". Mais recentemente, Park (1998) verificou que as mudanças de cor e textura estavam relacionadas principalmente aos diferentes grau de alteração destas rochas. De fato, a coloração mais clara aparece nas rochas mais próximas à zona mineralizada; o mesmo autor descartou a presença de "andesitos intrusivos". Atualmente, os andesitos basálticos são considerados como parte dos derrames de lavas do Vulcânico Paralaque do Grupo Toquepala (Bellido, 1979).

\section{Riolitos pórfiros}

Riolitos pórfiros, do Vulcãnico Quellaveco, ocorrem na vertente sul da quebrada Chuntacala e na vertente Norte da quebrada Torata (Concha \& Bernabé, 1999) formando derrames discordantemente sobrepostos aos andesitos basálticos, com leve caimento para W-SW (Manrique \& Plazolles, 1975); na região da jazida a espessura destas lavas alcança ca. $370 \mathrm{~m}$. São rochas com cores cinza rosada clara a esbranquiçada, contendo abundantes fenocristais euedrais de quartzo (até 4mm) em matriz afanítica. As estruturas são maciças, com fraturamento acentuado quando localizadas acima e/ou nas adjacências da zona alterada dos andesitos basálticos.

\section{"Doleritos" Toquepala}

O denominado "dolerito" Toquepala trata-se, em realidade de um derrame andesítico de coloração verde a marrom clara com textura porfirítica e granulação fina, estruturado em finas camadas. Na área da jazida estas rochas foram completamente erodidas, porém existem afloramentos ca. 2,5 km para W com espessuras que alcançam $130 \mathrm{~m}$ (Manrique \& Plazolles, $1975)$.

\subsubsection{Rochas Intrusivas}

As rochas intrusivas correspondem principalmente a dioritos e quartzo latitos, brevemente descritos a seguir.

\section{Dioritos}

Estas rochas afloram aproximadamente a $2 \mathrm{~km}$ a oeste do Cuajone, não aparecendo na zona mineralizada. Em planta constituem um pequeno corpo com forma irregular alongada, com eixo maior na direção Norte-Sul. Segundo Concha \& Bernabé (1999), são rochas com estruturas maciças e colorações variáveis em tonalidades de cinza, cinza esverdeado e cinza escuro, caracterizadas por dijunções colunares em superfície. As texturas são equigranulares de granulação média a grossa, ocasionalmente porfiríticas. São rochas intrusivas e cortam os 
andesitos basálticos e toda a seqüência do Grupo Toquepala. Determinações radiométricas pelo método K/Ar resultaram em uma idade de $67 \pm 2$ Ma Park (1998).

Um outro stock, formado por rochas similares, foi mapeado a $1,7 \mathrm{~km}$ a leste do corpo mineralizado, na quebrada Torata, com dimensões de $0,70 \times 0,35 \mathrm{~km}$ em superfície (Concha \& Bernabé, 1999).

\section{Quartzo Latitos}

Estas rochas constituem o principal corpo intrusivo de Cuajone, alongado segundo a direção NW-SE. Datações radiométricas pelo método K/Ar resultaram em idades entre 52 e 57 Ma (Estrada, 1985; McBride, 1977; Zweng, 1984; Beckinsale et al., 1985; Clark et al., 1990b; Park, 1998).

Segundo Satchwell (1983), a zona de cava é formada por dois corpos de quartzo latitos. O primeiro apresenta-se fortemente alterado e mineralizado, enquanto o segundo, localizado na zona central (denominada brecha central) é estéril e pouco alterado. Mais recentemente, Concha \& Bernabé (1999) distinguiram três episódios contrastados de formação de quartzo latitos, como segue:

O primeiro evento magmático, que forma os quartzo latitos da cava principal, constitui um corpo intrusivo que aflora no setor sudeste e é associado com a mineralização de $\mathrm{Cu}-\mathrm{Mo}$. As rochas intrusivas e suas encaixantes encontram-se fortemente alteradas e mineralizadas. $\mathrm{O}$ segundo evento é responsável pela colocação do denominado quartzo latito estéril (barren latite porphyry), que, conquanto mineralizado, não apresenta teores economicamente interessantes. Esta rocha constituem dois corpos distintos, que invadem as rochas mineralizadas do primeiro pulso. O corpo central apresenta forma alongada segundo direção NW, com dimensões de 300 vs $200 \mathrm{~m}$. O corpo que aflora a noroeste é maior, apresentando 850 vs $550 \mathrm{~m}$. O terceiro evento magmático, mais jovem, está representado por um corpo situado a noroeste dos corpos anteriores, no vale do rio Torata, com diâmetro de $c a .800 \mathrm{~m}$. A rocha está fracamente alterada e não se observa qualquer tipo de mineralização.

\section{Brechas e Diques}

Brechas magmáticas e diques se associam à colocação dos quartzo latitos do segundo evento magmático e situam-se, em geral nas zonas de contato entre rochas dos diferentes eventos, concentrando-se algumas vezes nas zonas de falhas e fraturas.

As brechas são compostas de fragmentos líticos de composições andesíticas e latíticas imersos em uma matriz de latito pórfiro. De acordo com as abundâncias em Cu são subdivididas em brechas mineralizadas (teores $>0,40 \%$ em peso), marginais (entre 0,10 e 0,40\%) e estéreis (com teores inferiores a 0,10\%), (cf. Concha \& Bernabé, 1999). Os diques estão constituídos de quartzo latitos. Alcançam extensões de até $800 \mathrm{~m}$ e espessuras de até $3 \mathrm{~m}$. São orientados segundo NW e E-W e apresentam mineralização disseminada com teores baixos. 


\subsubsection{Rochas Pós-Mineralização}

Correspondem às fases vulcânicas das Formações Huaylillas e Chuntacala.

\section{Formação Huaylillas}

Esta Formação aflora em partes da zona sul e sudeste da cava e na vertente norte do rio Torata. Apresentam idade determinada pelo método de $\mathrm{K} / \mathrm{Ar}$ de 22,8 \pm 0,7 Ma (Tosdal et al., 1981). Na área da mina, são descritas as seguintes unidades da base ao topo:

Conglomerado riolítico, se localiza na parte leste da cava, preenchendo um paleo-vale com direção W-E, com espessura máxima de $110 \mathrm{~m}$. Esta unidade é composta de clastos riolíticos em matriz argilosa tufácea (Concha \& Bernabé, 1999);

Tufo Salmón, localiza-se na vertente sul da quebrada Chuntacala, sobrepõem-se, em discordância erosiva, às rochas pré - mineralização, às rochas intrusivas e aos conglomerados riolíticos, com uma espessura de ca. 16 m (Concha \& Bernabé, 1999). São rochas friáveis, de granulação fina, com típico fraturamento conchoidal;

Vitrófiros, são rochas muito frágeis com fratura conchoidal, com colorações variáveis entre rósea a preta no topo e espessuras variáveis entre 10 a 20 m (Uyén, 1981);

Traquitos, se localizam na parte sul e norte da cava com típicas estruturas de bandamento de fluxo magmático e vesicular, com vesículas de diâmetros variados. Apresentam textura porfirítica, com fenocristais de feldspato alcalino e, em menor proporção, biotita, imersos em matriz silicificada. Segundo Uyén (1981) suas espessuras chegam até 150 m, no entanto Concha \& Bernabé (1999) consideram espessuras máximas de 30 m;

Tufo branco, uma rocha que ocorre nas regiões sul e sudeste da cava, com uma espessura aproximada de $30 \mathrm{~m}$, caracterizada por apresentar estrutura maciça e fragmentos líticos de diferentes composições (Uyén, 1981);

Logo após a deposição do Tufo branco tem-se uma etapa erosiva, que faz com que a Formação Huaylillas praticamente desapareça na região das quebradas Chuntacala e Torata, formando um paleovale. Este episódio erosivo provavelmente ocorreu entre 19 e 21 Ma Clark et al. (1990a). Posteriormente este paleovale foi preenchido pelas seguintes unidades, da base para o topo:

Conglomerado Traquítico, composto por clastos traquíticos e tufos sub- angulosos em matriz tufácea, com espessuras de $15 \mathrm{~m}$;

Conglomerado Verde e Amarelo, rocha composta por clastos angulosos a subarredondados de andesitos, riolitos, latitos, brechas, traquitos e tufos de dimensões variadas, em matriz de andesitos. Preenchem paleo-vales nas regiões leste e oeste da cava atual, com espessuras da ordem de $30 \mathrm{~m}$; 
Aglomerado Cinzento, rocha composta por clastos angulosos a arredondados de andesitos em matriz tufácea, com tonalidades pretas, cinzentas e vermelhas. Afloram no paleo-vale da quebrada Chuntacala;

Aglomerado Tufáceo, formado por clastos angulosos a sub-arredondados de traquitos e tufos em matriz tufácea. Corresponde à última rocha da seqüência da formação Huaylillas e aflora na vertente sul da quebrada Chuntacala com espessuras de $20 \mathrm{~m}$;

Conglomerado Basal, composto por clastos de andesitos, riolitos, traquitos, latitos e tufos imersos em matriz argilosa., com uma espessura de $32 \mathrm{~m}$. Aflora em discordância erosiva sobre as rochas intrusivas pré-mineralização, intrusivas e Aglomerado Cinza. Clark et al. (1990a) inclui estas rochas na seqüência da Formação Huaylillas, enquanto que Concha \& Bernabé (1999) consideram-as como a base da Formação Chuntacala.

\section{Formação Chuntacala}

Após uma seqüência erosional múltipla, que originou um amplo vale entre os atuais vales de Chuntacala e Torata, inicia-se há ca. 13,1 \pm 0,4 Ma a deposição de uma sucessão de tufos de cinzas, aglomerados e fluxos vulcânico-glacial pouco consolidados que constituem a Formação Chuntacala (Tosdal et al., 1981). Na região da mina, é reconhecida a seguinte seqüência de rochas, da base ao topo:

Tufo Cristal, uma seqüência composta, na base, por um tufo cinza branco com bandamento de fluxo e, no topo, por um tufo marrom claro. O Tufo Cristal apresenta cristais de feldspato alcalino e micas imersos em matriz muito fina que, ocasionalmente, contém vesículas preenchidas por material vítreo. Apresenta espessura de $120 \mathrm{~m}$;

Tufo Inferior, rocha caracterizada por megacristais/fenocristais de feldspato alcalino, biotita e mica branca em matriz afanítica, com cores brancas a branco-amareladas. Aflora no setor norte da cava, com espessura de até $90 \mathrm{~m}$;

Aglomerado Inferior, rocha formada por clastos subangulosos a sub-arredondados de andesitos imersos numa matriz tufácea consolidada, com cor marrom escura e espessura de até $90 \mathrm{~m}$.

Tufo Superior, rocha de composição geral traquítica, com espessuras de até 30m (Uyén, 1981).

Aglomerado Superior, composto por clastos de rochas vulcânicas de diferentes tamanhos e composições (andesitos, riolitos, tufos, etc.), todos eles englobados em matriz moderadamente compacta, com espessuras de até 50 m (Uyén, 1981).

Andesito Pórfiro, esta rocha, constitue o topo da formação Chuncatala, apresenta cor verde, fortemente fraturada e com espessura de $20 \mathrm{~m}$. 
Segundo Clark et al. (1990b) depois da depositação da Formação Chuntacala inicia-se, há ca. 6,5 Ma, um período de erosão que afeta as formações vulcânicas Huaylillas e Chuntacala a qual renova uma incisão no corpo mineralizado ao longo do eixo do vale Chuncatala.

Depósitos Aluviais, cobrem toda a seqüência. São compostos de clastos arredondados, subarredondados e angulosos de rochas, em sua maioria vulcânicas, englobados por matriz areno-argilosa.

\subsection{Geologia Estrutural Local}

\subsubsection{Fraturas e falha}

As intrusões dos diferentes corpos intrusivos, especialmente o mineralizado, geraram um intenso fracturamento tipo stockwork, devido a pressão exercida pelo magma invasor e, em parte, pelos próprios fluídos hidrotermais. Este tipo de fraturamento facilitou a entrada dos fluídos responsáveis pela alteração hidrotermal e conseqüente mineralização. Nas fraturas desenvolvem-se zonas silicificadas ou zonas com rochas muito frágeis (Satchwell, 1983).

As rochas vulcânicas pós - mineralização apresentam padrões de fraturamento distintos. Nos Traquitos e Tufo Cristal ocorre fracturamento sub-horizontal e sub-vertical a conchoidal, produzindo blocos retangulares a arredondados de diversos tamanhos (Concha \& Bernabé, 1999). Nos conglomerados e aglomerados o fracturamento é menos intenso e de tipo irregular a conchoidal (Satchwell, 1983).

Um alinhamento localizado na parte sudoeste da cava corresponde à zona de falha mais importante, denominada Falha Maior Sul. Apresenta direção preferencial de $212^{\circ} \mathrm{e}$ mergulho de $57^{\circ}$, com extensão verificada de $950 \mathrm{~m}$ e uma espessura variável de até $50 \mathrm{~m}$. A zona de falha é preenchida por material intensamente fraturado, brechado e triturado (Concha \& Bernabé, 1999). 



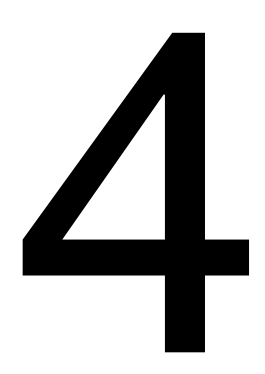

\section{Materiais e métodos}

\subsection{Amostragem}

Este trabalho é baseado no estudo de amostras de testemunhos de furos de sonda recuperados em diferentes campanhas de perfuração na mina Cuajone. A seleção das amostras foi realizada com assistência de dois engenheiros geólogos, funcionários do departamento de explorações do Southern Peru Corporation: Berthing Herrera e Jesus Chara, profundos conhecedores da jazida. A escolha da zona de trabalho e dos testemunhos representativos foi feita considerando os diferentes tipos de alteração hidrotermal e a distribuição da mineralização associada.

Inicialmente foram selecionados alguns perfis contendo furos representativos com as características acima mencionadas. Após a verificação de que amostras dos furos selecionados ainda se encontravam disponíveis, foram escolhidas amostras representativas das zonas de alteração e mineralização primária (zona de sulfetos primários). Este trabalho foi feito com a ajuda de mapas de localização dos furos de sonda, geológico e de alguns perfis geológicos e de alterações hidrotermais fornecidos pelo departamento de Geologia da mina Cuajone, os quais permitiram o controle adequado para a escolha de amostras.

Durante os trabalhos de campo, foram coletadas e descritas cerca de 222 amostras, representativas de 72 furos selecionados, com a ajuda de dois obreiros para mover as caixas dos furos de sondagem, além da assistência dos engenheiros geólogos acima mencionados. 


\subsection{Coloração Seletiva de Feldspato}

A coloração seletiva de feldspatos é um método importante quando, por quaisquer razões, os feldspatos (plagioclásios vs. feldspatos potássicos) não podem ser adequadamente reconhecidos em amostras de mão ou em seções petrográficas. Uma vez que as rochas estudadas são em geral porfiríticas, com matriz fina ou muito fina, variavelmente transformadas por alteração hidrotermal, este procedimento foi seguido para a maioria das amostras. O método baseiase na reação entre cobalto nitrito de sódio e feldspato potássico, acelerada pelo tratamento prévio deste último com HF, que origina uma fina película de cobalto nitrito de potássio sobre o feldspato potássico, a qual apresenta uma coloração amarela muito viva e típica, tornando muito fácil a separação deste com plagioclásio e quartzo, que não são afetados. O procedimento analítico adotado corresponde ao descrito em MaKenzie \& Adams (1997), tal como brevemente resumido a seguir.

Fatias de rocha com espessuras entre $3 \mathrm{~mm}$ a $1 \mathrm{~cm}$ de espessura, em cortes transversais às estruturas direcionais quando presentes, foram obtidas a partir das amostras de mão, utilizandose de serras diamantadas no Laboratório de Preparação de Amostras do Departamento de Mineralogia e Geotectônica (GMG). Na etapa seguinte, efetuada cuidadosamente em capelas específicas, devido aos perigos de contato físico ou aspiração de HF, no Laboratório de Química e ICP do Departamento de Mineralogia e Geotectônica (GMG), as fatias foram parcialmente imersas em bandeja plástica com HF concentrado por cerca 1 min, lavadas em água destilada circulante e, em seguida, mergulhadas em outra bandeja plástica com solução saturada de cobalto nitrito de sódio por ca. 2 min. As fatias, agora coloridas, foram lavadas com água destilada e deixadas para secar por evaporação natural.

\subsection{Petrografia microscópica}

Para os estudos petrográficos foram selecionados 22 entre os 72 furos de sondagem estudados no campo, com um total de 76 amostras. Dois destes furos atravessam os corpos estéreis, o primeiro (R) localizado na zona central do corpo mineralizado e o outro (I) a noroeste do primeiro. Estes furos e respectivas amostras permitiram construir três perfis (P-1, P-2 e P-3) no corpo mineralizado (Figura 4.1).

O primeiro orientado E-W com sete furos (A-G), o segundo, NW-SE, com três furos (H, I e J) e o terceiro, também de direção E-W, com um total de 12 furos de sondagem (K-V). Na seleção destas seções procurou-se abranger todos os tipos de rocha presentes na cava.

Foram confeccionadas 70 lâminas delgado-polidas na Seção de Laminação do Laboratório de Microssonda Eletrônica e 6 lâminas delgadas no Laboratório de Preparação de Amostras do Instituto Geológico Minero Metalúrgico - IGEMMENT - Perú. As lâminas foram confeccionadas em cortes transversais às estruturas (veios) em amostras previamente impregnadas com resina, uma vez que estas apresentam graus variáveis de alteração. 


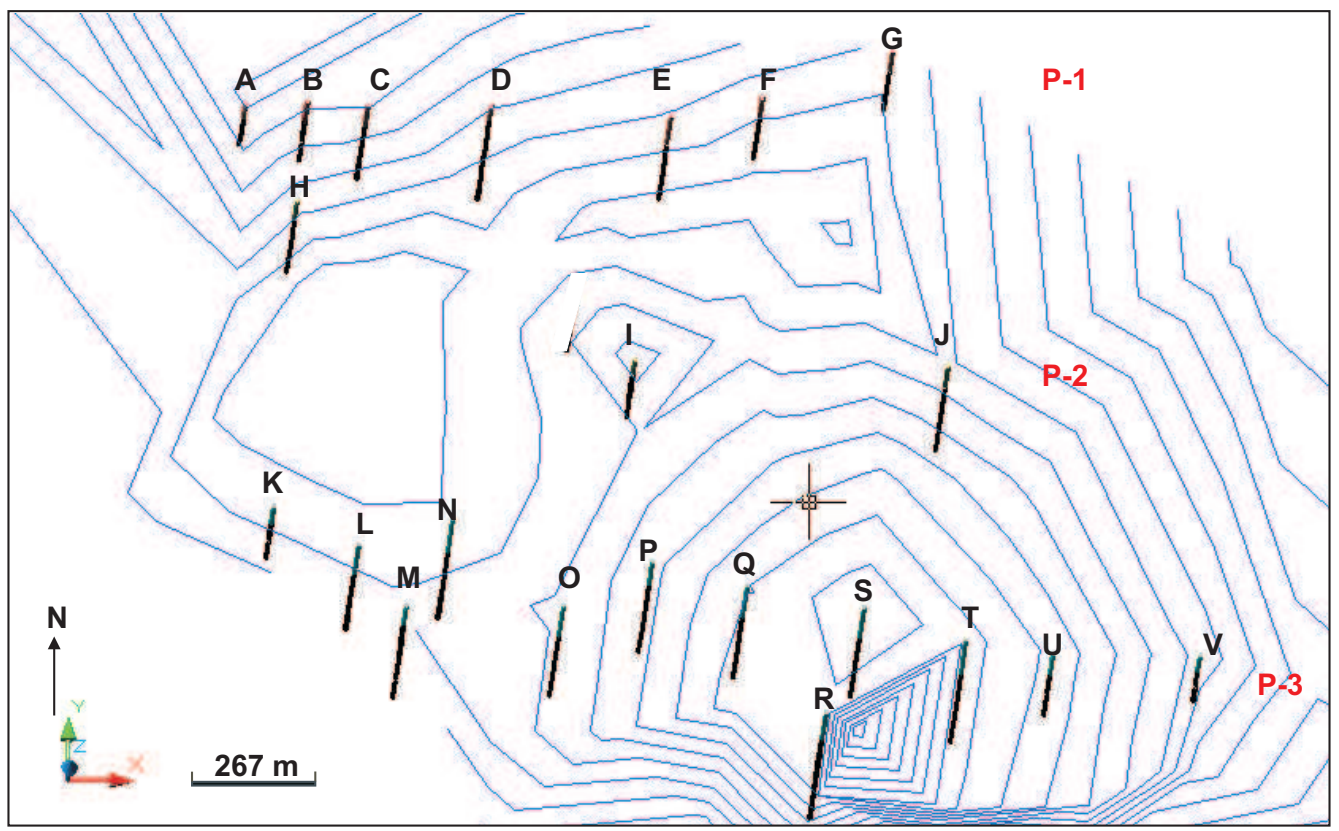

Figura 4.1: Localização e distribuição dos furos de sondagem das três seções construídas na Jazida de Cuajone.

As análises ao microscópio foram efetuadas no Laboratório de Microscopia Petrográfica do GMG com os microscópios Zeiss, modelo Axioplan, com campo visual entre 10 e 0,49 mm e aumento máximo de 400x; Olympus, modelo BX50, com campo visual entre 4,4 e 0,44 mm e aumento máximo de 400x e o estereomicroscópio Zeiss, modelo SV-8 e aumento de 8x a 64x. Os trabalhos iniciais foram efetuados sob luz transmitida polarizada objetivando a identificação das associações minerais primárias e de alteração, texturas e determinações modais (algumas efetuadas por estimativa visual) para a determinação da abundância relativa dos minerais formadores de rocha e dos minerais formados durante o processo de alteração. É importante mencionar que em diversas situações, a análise textural, por si só, não permite assegurar com certeza quando um mineral é primário ou de alteração, particularmente quando este pode aparecer em ambas paragêneses, como o quartzo e o feldspato potássico.

As descrições efetuadas foram baseadas nos trabalhos de Kerr (1972), Pichler \& SchmittRiegraf (1997), Klein (2002), MacKenzie \& Guilford (1980), MacKenzie et al. (1982), Williams et al. (1982), Castro (1989), MacKenzie (1994) e Melgarejo (2003).

Para a determinação do teor de anortita dos plagioclásios foi utilizado o método de MichelLevy, no qual é usado o máximo ângulo de extinção dos geminados da Lei da Albita em cortes da zona [010], na qual os traços dos planos de geminação podem ser observados com nitidez e os indivíduos geminados apresentam uma cor de interferência uniforme sob polarizadores cruzados. Nestes cortes, os ângulos são similares quando a platina é girada para a esquerda ou para a direita.

Uma vez localizada uma seção que cumpra estes requisitos se orienta os planos da geminação paralelos à direção do polarizador (N-S), logo são medidos os ângulos de extinção à direita e 
esquerda das dos series de geminação. Se a diferença entre os dois ângulos é menor o igual que $6^{\circ}$, a media pode ser realizada. O valor obtido é levado ao digrama de Michel-Levy que dá o teor em molécula de anortita correspondente. Quando o ângulo médio de extinção é menor ou igual a $19^{\circ}$ existe uma indeterminação, a qual pode ser resolvida determinando o índice de refração do plagioclásio em relação ao balsamo ou ao quartzo. Se o índice de refração do plagioclásio é menor que do bálsamo, sabe-se que $A n<20$ e se é maior $A n>20$. Informações mais detalhadas podem ser encontradas em Nesse (1991) e Kerr (1972).

Na classificação das rochas seguiu-se a recomendação da IUGS (LeMaitre, 1989), procurandose classificar apenas as variedades menos alteradas do conjunto amostral. No caso do latito e andesito-II a classificação adotada foi de caráter indicativo já que existe um grau de incerteza no estabelecimento do limite entre feldspato potássico de origem primária, ígnea ou secundária, por alteração hidrotermal. Igualmente, os pórfiros-I e II foram classificados entre micro monzogranitos - quartzo monzonitos e micro tonalitos - micro leucoquartzo dioritos porfirítico respectivamente, devido à incerteza na natureza primária ou secundária de parcela do quartzo presente nestas rochas.

As rochas fortemente alteradas foram classificadas em pórfiros alterados e hidrotermalitos. O termo pórfiro alterado foi aplicado às rochas que, embora a textura estivesse preservada, a intensidade da alteração não permitiu sua classificação, enquanto que o termo hidrotermalito foi utilizado para as amostras com grau de alteração muito avançado, que obliterou quase que totalmente a mineralogia e as texturas primárias (e.g., amostras H-1 e F-1). No primeiro caso, a alteração dominante é a fílica-propílica gerando uma coloração esverdeada à rocha, enquanto que no segundo são observadas alterações propílica, fílica e potássica resultando em colorações variáveis de verde acinzentadas, cinzas claras e cinzas rosadas, respectivamente.

Tanto para o pórfiro quanto para o hidrotermalito, a nomenclatura foi baseada na quantidade majoritária dos minerais de alteração presentes. Exemplos destes tipos de rochas são mostrados na prancha 9 , fotos C, D e E.

Um resumo das diferentes rochas presentes nos três perfis mencionados e das suas respectivas alterações é apresentado no Anexo 3.

A análise das associações minerais, particularmente aquelas determinantes do tipo de alteração hidrotermal foi feita com base nos trabalhos de Rose (1970), Lowell \& Guilbert (1970), Gustafson \& Hunt (1975), Muñoz (1980), Titley \& Beane (1981), Maksaev (2001) e Townley (2001). Na maioria dos casos estudados, os minerais de alteração presentes são comparáveis com os padrões já estabelecidos em literatura, mas algumas vezes a caracterização do tipo de alteração foi feita com base na presença de apenas dois minerais típicos, por exemplo: cloritaepidoto caracterizando a alteração propílica.

O estudo dos minerais opacos e, particularmente das inclusões sólidas encontradas em pirita, foi feito de forma minuciosa sob luz refletida. Foi realizada uma análise estatística 


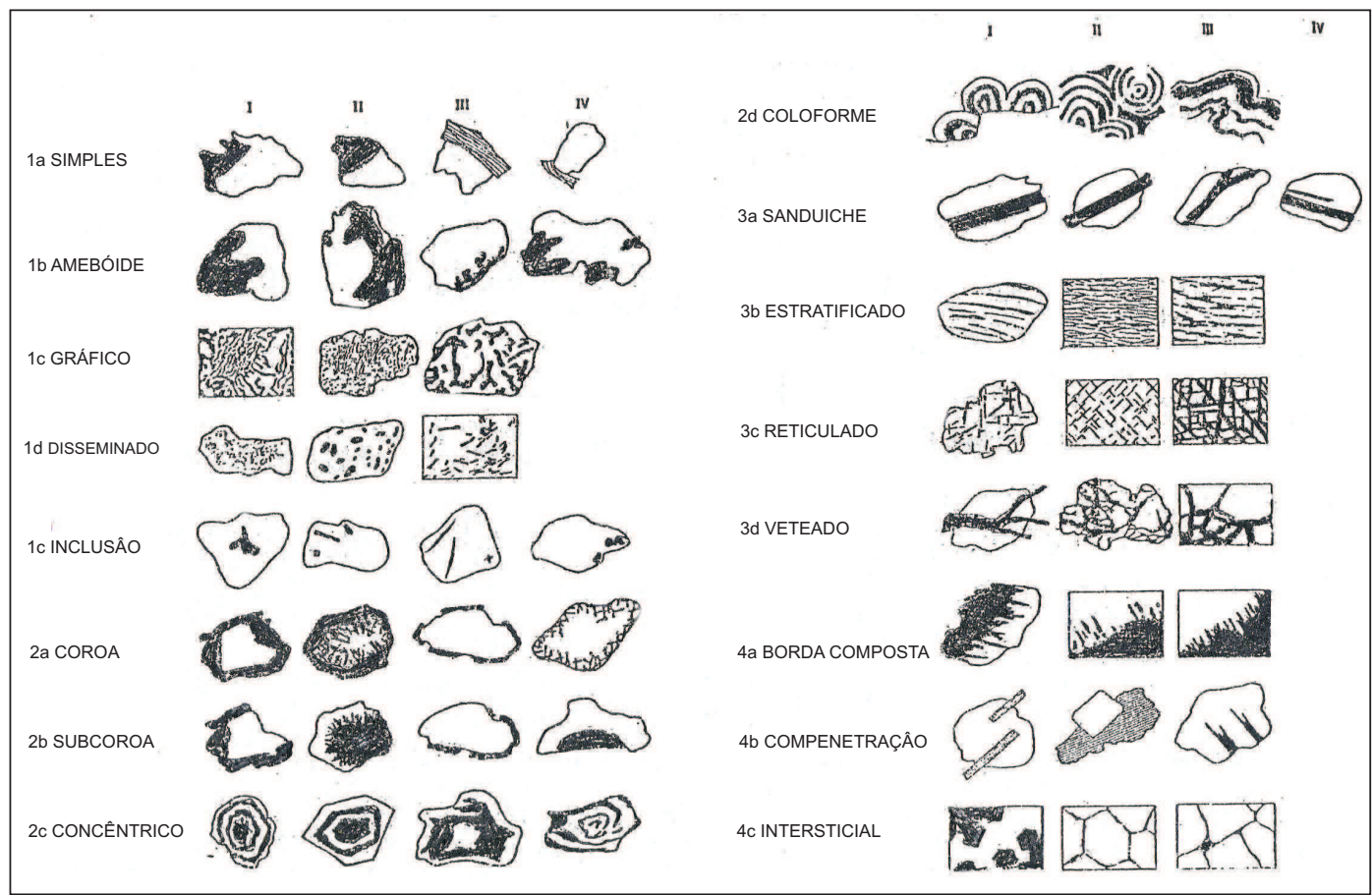

Figura 4.2: Principais tipos de intercrescimentos entre fases sulfetadas, de acordo com Canchaya \& Cardoso (1984).

das inclusões presentes em cada grão de pirita encontrado nas seções examinadas, tabelandose diversos aspectos relevantes, como forma, tamanho e tipos e número de intercrescimentos encontrados. Paralelamente, as texturas e o tipo de ocorrência dos cristais de pirita e outros opacos foram analisadas em detalhe. Nestes estudos foram utilizados, como referência, os trabalhos de referência Edwards (1954), Cameron (1961), Schouten (1962), Oelsner (1966), Uytenbogaardt (1971), DeMichele (1972), Ramdohr (1980), Troger (1979), Park \& MacDiarmid (1981), Ixer (1990), Hagel (1994), Demidov \& Muñoz (1993) e Augustithis (1995). Os tipos de intercrescimento foram classificados de acordo com o trabalho de Canchaya \& Cardoso (1984) (Figura 4.2).

A documentação digital dos aspectos petrográficos e mineralógicos foi feita com a câmera digital Olympus PM-20, acoplada ao microscópio Olympus BX50. Foram tomadas mais de 400 fotomicrografias, entre as quais as mais significativas foram selecionadas para ilustrar este trabalho. Merece ser mencionada a dificuldade de documentar algumas das inclusões, devido a problemas de foco e resolução ocasionados pelas suas dimensões, muitas vezes diminutas.

\subsection{Imageamento composicional e Química Mineral}

Análises de imagens eletrônicas, de eletrons retro-espalhados e raios X (composicionais) e análises químicas pontuais foram realizadas em 15 seções delgadas polidas selecionadas, objetivando estudar as texturas e as variações composicionais das inclusões sólidas presentes em cristais de pirita. Estas seções representam diferentes tipos de alteração presentes nos perfis 


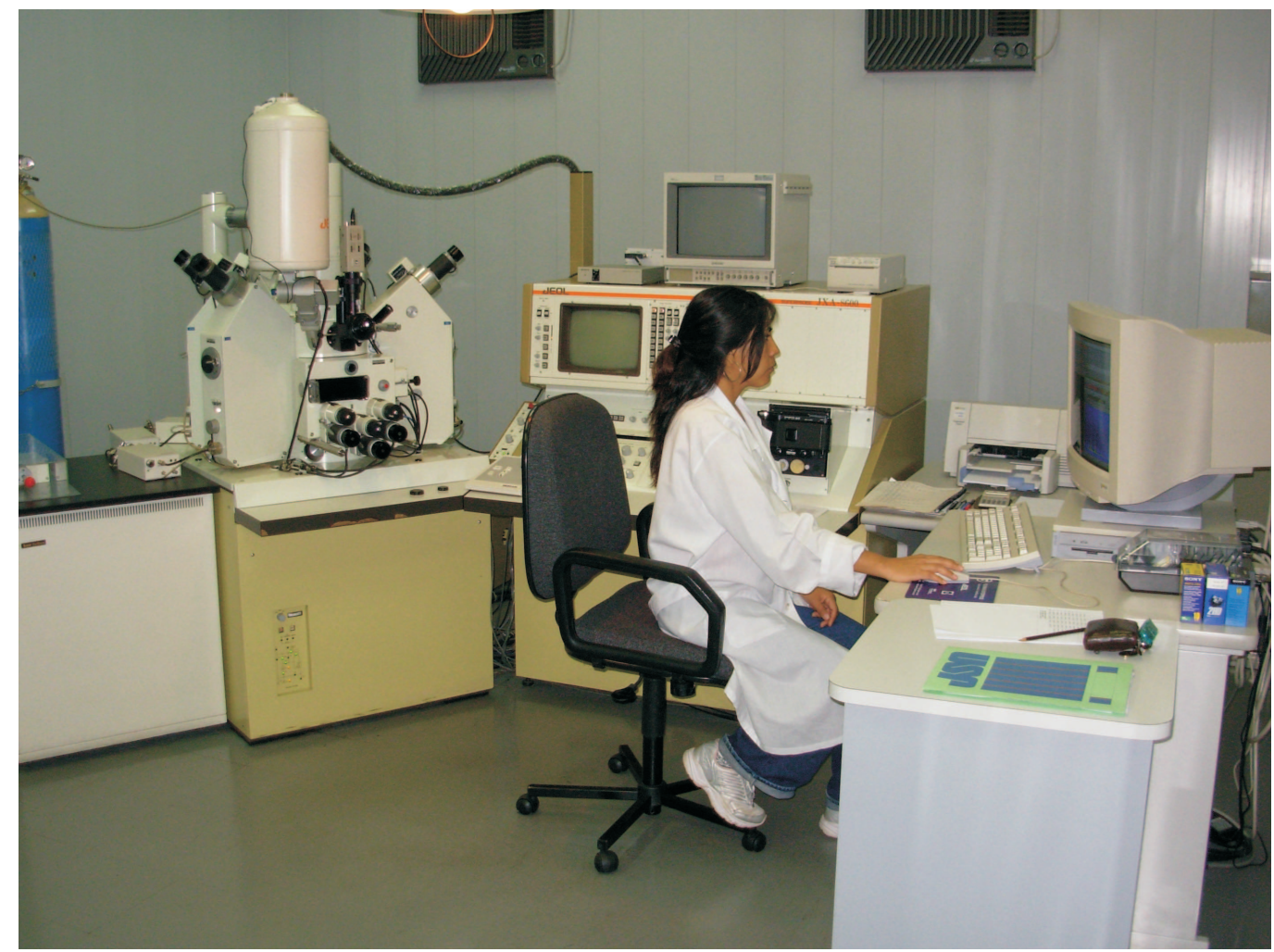

Figura 4.3: Fotografia tomada da Microssonda Eletrônica do Departamento de Mineralogia e Geotectônica do Instituto de Geociências da Universidade de São Paulo.

amostrais selecionados na jazida. Os grãos de pirita com inclusões sólidas foram escolhidos após os estudos detalhados de microscopia sob luz refletida. Depois de documentados em imagens digitais, a sua localização foi efetuada com um marcador digital de pontos do Laboratório de Microssonda Eletrônica, composto uma platina automática Zeiss acoplada a um microscópio Zeiss, controlador de platina Microbean e software Digimax para registro de coordenadas em computador PC.

As análises foram realizadas no Laboratório de Microssonda Eletrônica do GMG do Instituto de Geociências da USP. O equipamento utilizado foi um JEOL JXA-8600 Superprobe, provido com cinco espectrômetros (cristais TAP/STE, TAP/PET, LIF/PET, PET/LIF e LIF/PET) de dispersão de comprimento de onda (WDS) e um de dispersão de energia (EDS). O equipamento é automatizado através do sistema Voyager 3.6.1 da NORAN Instruments de hardwares e softwares (Figura 4.3). As determinações foram efetuadas nas seções delgado-polidas metalizadas com uma película de carbono $(25 \mathrm{~nm})$ em evaporador AUTO 206 EDWARDS.

Estas análises foram feitas em três etapas consecutivas. Na primeira foram obtidas imagens de elétrons retro-espalhados em modo composicional (BEI-COMPO), com utilização eventual de EDS para a caracterização qualitativa de algumas fases, na segunda foram obtidas análises quantitativas pontuais para pirrotita, cubanita, mackinawita, calcopirita e pirita que constituem os intercrescimentos mais típicos nas inclusões. Por último foram obtidos mapas composicionais para ilustrar a distribuição dos elementos S, Fe, Cu, Ni e Si analisados em WDS 
e Co, Zn e Au em EDS. A seguir é descrita detalhadamente cada fase realizada neste trabalho.

\subsubsection{Imagens de Elétrons Retro-espalhados (BSE)}

As imagens de elétrons retro-espalhados (BSE) em modo composicional (BSE-Compo) refletem o aumento do coeficiente de restroespalhamento com o aumento do número atômico (Z). Assim, as imagens BSE revelam contrastes que traduzem as variações pixel a pixel do número atômico médio na área analisada. Estes contrastes se expressam em 256 tons de cinza, variando deste o branco (número atômico médio mais alto na área considerada), até o negro (número atômico médio mais baixo).

O cálculo do coeficiente de retroespalhamento segue uma regra simples de mistura baseada na concentração em peso de cada constituinte individual, como segue:

$$
\eta=\sum_{i=1}^{n} X_{i} \eta_{i}
$$

Onde: $\eta=$ coeficiente de retroespalhamento de um composto constituído por $i$ elementos, $\eta_{i}=$ coeficiente do elemento $i, X_{i}=$ fração em peso do elemento $i$.

Os sulfetos estudados são compostos essencialmente pelos elementos $\mathrm{S}$, Fe e $\mathrm{Cu}$ com números atômicos 16, 26 e 29, respectivamente. Entre eles, as imagens BSE não são as mais adequadas para contrastar pirrotita e mackinawita, uma vez que estes minerais possuem composição química muito parecida. Por outro lado estas imagens permitem contrastar prontamente entre calcopirita, cubanita e pirrotita ou mackinawita, em ordem decrescente de coeficientes de retro-espalhamento.

\subsubsection{Análises pontuais quantitativas}

Na microssonda eletrônica, o bombardeio de elétrons sobre a amostra faz com que esta emita raios X característicos e de fundo. A análise do comprimento de onda dos raios X característicos através dos espectrômetros de dispersão de comprimentos de onda (WDS) permite reconhecer quais são os elementos emissores e, portanto, quais elementos estão presentes na amostra. A comparação das intensidades de emissão de amostras e de padrões, com composições químicas bem determinadas, permite quantificar os elementos detectados na amostra. Uma característica marcante do método é que a microssonda permite focar um feixe eletrônico muito fino e, portanto, a área analisada na amostra pode ser muito pequena, com diâmetro da ordem de poucos micrômetros.

Para a analise quantitativa dos sulfetos estudados foi elaborada uma rotina analítica própria, cujas características gerais são reproduzidas na Tabela 4.1. As posições de leitura das radiações característica e de fundo foram cuidadosamente selecionadas para evitar interferências espectrais. As analises foram efetuadas em condições analíticas de $20 \mathrm{kV}$ para a voltagem de aceleração da coluna eletrônica, e $30 \mathrm{nA}$ para corrente do feixe eletrônico. O diâmetro do feixe 
Tabela 4.1: Características gerais da rotina utilizada para análise WDS de sulfetos.

\begin{tabular}{|c|c|c|c|c|c|}
\hline Elementos & Linhas & Cristal & Espectrômetros & $\begin{array}{c}\text { Tempo de } \\
\text { contagem (s) }\end{array}$ & Padrão \\
\hline $\mathrm{Mg}$ & $\mathrm{Ka}$ & TAP & Spec1 & 30 & Enstatita \\
\hline $\mathrm{Si}$ & $\mathrm{Ka}$ & TAP & Spec1 & 30 & Wollastonita \\
\hline As & $\mathrm{La}$ & TAP & Spec1 & 50 & $\mathrm{PtAs}_{2}$ \\
\hline $\mathrm{S}$ & $\mathrm{Ka}$ & PET & Spec2 & 5 & $\mathrm{FeS}_{2}$ (Pirita) \\
\hline $\mathrm{Ca}$ & $\mathrm{Ka}$ & PET & Spec2 & 30 & Wollastonita \\
\hline $\mathrm{Ag}$ & $\mathrm{La}$ & PET & Spec2 & 40 & $\mathrm{AgBi} \mathrm{Se} 2$ \\
\hline $\mathrm{Mn}$ & $\mathrm{Ka}$ & $\mathrm{LIF}$ & Spec3 & 50 & Mn (metálico) \\
\hline $\mathrm{Fe}$ & $\mathrm{Ka}$ & LIF & Spec3 & 5 & $\mathrm{FeS}_{2}$ (Pirita) \\
\hline $\mathrm{Ni}$ & $\mathrm{Ka}$ & LIF & Spec4 & 50 & $\mathrm{Ni} \mathrm{Sb}$ \\
\hline $\mathrm{Zn}$ & $\mathrm{Ka}$ & LIF & Spec4 & 40 & $(\mathrm{Zn}, \mathrm{Fe}) \mathrm{S}$ \\
\hline Co & $\mathrm{Ka}$ & LIF & Spec5 & 30 & $\mathrm{CoO}$ \\
\hline $\mathrm{Cu}$ & $\mathrm{Ka}$ & LIF & Spec5 & 10 & CuS (covelita) \\
\hline $\mathrm{Au}$ & $\mathrm{La}$ & LIF & Spec5 & 40 & Au (metálico) \\
\hline
\end{tabular}

incidente variou entre 1 e $5 \mu \mathrm{m}$ em função das dimensões dos cristais analisados em intercrescimentos. Em algumas ocasiões, devido as dimensões muito diminutas de algumas das inclusões, particularmente cubanita e mackinawita, houve certa dificuldade no posicionamento preciso do feixe eletrônico sobre apenas uma fase mineral, mesmo utilizando o diâmetro minimo possível.

As correções para os efeitos de matriz (número atômico, absorção de massa e fluorescência secundária) e as conversões para porcentagens em peso de elementos foram efetuadas com o programa PROZA (e.g. Bastin, 1984). Para o cálculo das formulas estruturais dos minerais analisados foram utilizadas planilhas do Microsoft Excel TM. Os erros relativos totais máximos estimados para as análises situam-se entre 1 e $2 \%$ em peso para os elementos maiores e acima de $10 \%$ para elementos traço ( $<1 \%$ em peso do elemento).

\subsubsection{Mapas Composicionais}

Para analisar detalhes texturais e a distribuição dos elementos, particularmente $\mathrm{Cu}, \mathrm{Fe}$, Ni e S, nos sulfetos estudados foram selecionados alguns intercrescimentos mais típicos, que continham dois ou três destes minerais, para a obtenção de mapas de raios X, com utilização simultânea dos espectrômetros de WDS e EDS. Imagens adicionais BSE-Compo foram obtidas simultaneamente. Os mapas obtidos correspondem aos denominados X-ray dot maps (e.g., Goldstein et al., 1992) e são de natureza qualitativa ou semi-quantitativa. Os elementos considerados foram $\mathrm{S}, \mathrm{Cu}, \mathrm{Fe}, \mathrm{Ni}, \mathrm{Si}, \mathrm{Co}, \mathrm{Zn}, \mathrm{Au}$.

A aquisição destes mapas é baseada na mesma técnica para a obtenção de imagens eletrônicas, 
em que o feixe eletrônico varre uma área selecionada da amostra e as radiações emitidas ponto a ponto são analisadas nos espectrômetros de dispersão de comprimentos de onda e/ou de dispersão de energia e armazenadas em uma matriz do tipo (x, y, I), em que x e y são coordenadas e I a intensidade detectada dos raios X.

Como neste tipo de análise o feixe eletrônico varre uma certa área, a condição quantitativa básica de que ponto de incidência do feixe eletrônico, cristal analisador e detector devem estar sobre um mesmo círculo, o Círculo de Rowland, não é obedecida. De fato, conforme o feixe se movimenta varrendo a amostra, o eixo óptico da microssonda passa a não coincidir com o eixo de foco do espectrômetro WDS ou o eixo de colimação do EDS (Goldstein et al., 1992). No caso do WDS, a conseqüência desta movimentação do feixe é que a fonte de raios-X na amostra se move para fora do Círculo de Rowland (Figura 4.4 Goldstein et al., 1992); assim a condição de Bragg não é mantida durante uma varredura, ocasionando distorções na imagem, com queda marcada da intensidade detectada, a qual é proporcional a distância do ponto focal ideal. A defocalização é tão mais pronunciada quando menor a ampliação da imagem, ou seja, quanto maior é á área varrida, sendo facilmente visível em magnificações inferiores a 500 X. (Goldstein et al., 1992). No caso das inclusões analisadas, dadas as suas dimensões muito pequenas ou mesmo diminutas, este efeito não é crítico. Devido ao tamanho da media das inclusões (X0.0 - 0.X microns) estudadas foi feito a seleção de inclusões maiores e tipo de intercrescimento adequado (minerais que abrangiam maiores áreas).

As condições analíticas para a obtenção destas imagens foram $20 \mathrm{kV}$ e $60 \mathrm{nA}$, considerandose um dwell time (tempo de integração de contagens) de 0,1 ms. As imagens foram obtidas com resolução de 512 x 512 pixéis e o tempo médio gasto para obtenção de cada uma foi da ordem de $12 \mathrm{~h}$. As contagens dos elementos Co, Zn e Au foram integradas com EDS, enquanto as de $\mathrm{S}, \mathrm{Fe}, \mathrm{Cu}, \mathrm{Ni}$ e Si foram integradas em WDS. O formato de saída selecionado para as imagens foi TIFF, colorido, em modo RGB 8 bits, convertido posteriormente para tons de cinza (16 bits). Um filtro equalizador do sistema Voyager foi utilizado para realçar os contrastes nas imagens apresentadas neste trabalho.

\subsection{Tratamento de Dados Gerais}

O tratamento dos dados obtidos foi efetuado com auxílio principalmente dos pacotes Microsoft Office 97 for Windows, Corel Draw 11.0, e Autocad 2006. Os dados dos tipos e número de intercrescimentos assim como dos minerais que os tipificam foram analisados em gráficos de barras para indicar a freqüência em cada alteração hidrotermal da Jazida Cuajone e comparar os resultados obtidos para outras jazidas. As imagens obtidas na microssonda eletrônica foram tratadas no programa Corel Photo Paint 12 e Corel Draw 11.0.

Os dados quantitativos obtidos a partir dos estudos petrográficos (alteração, mineralogia e tipos dos intercrescimentos e rocha) foram analisados com o programa Datamine do Laboratório de Planejamento e Otimização de Lavra LAPOL do Departamento de Engenharia de Minas 


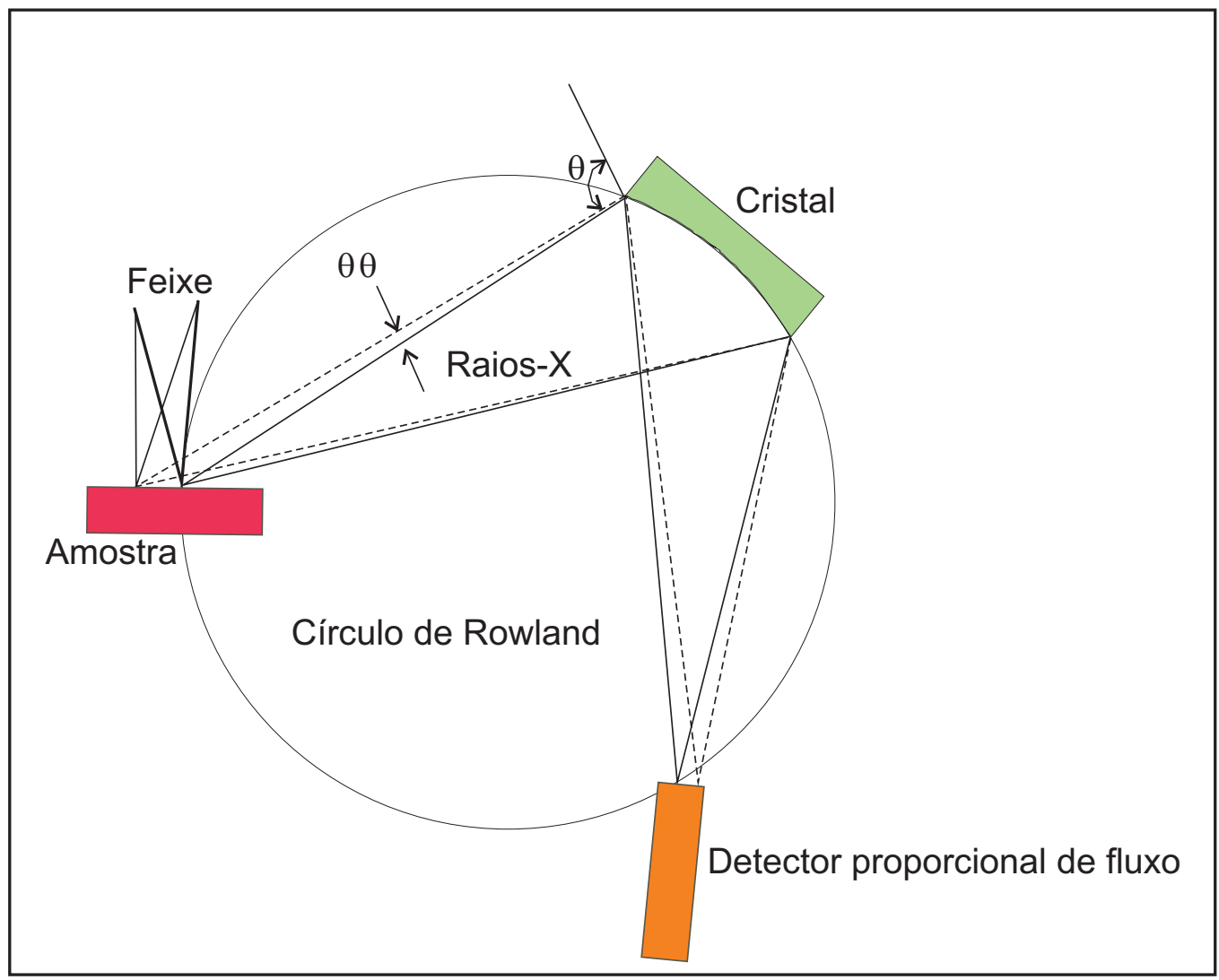

Figura 4.4: Defocagem WDS durante a confecção do mapa composicional, de acordo com Goldstein et al. (1992).

e Petróleo POLI-USP. Este é um programa muito útil para captura e análise de informação geológica, exploração, geoquímica, mecânica de rochas, topografia, modelamento geológico, desenho da cava a céu aberto e subterrâneo, planejamento minero e áreas relacionadas a estudos ambientais. Este programa permitiu a representação gráfica dos três perfis elaborados, com as diferentes variáveis definidas nos estudos petrográficos. 


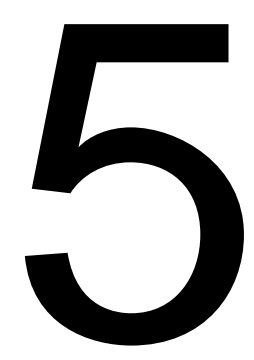

\section{Petrografia geral}

O estudo das amostras representativas dos furos selecionados na Jazida Cuajone para análise petrográfica permitiu reconhecer e classificar duas variedades de andesitos (andesitos propriamento ditos e os ora denominados andesitos-II), riolitos, quartzo latitos, latitos, microgranodioritos porfiríticos, micro-tonalitos, duas variedades denominadas Pórfiro I e Pórfiro II com classificação petrográfica ainda incerta, bem como microbrechas.

No caso dos Pórfiros I e II as proporções modais estimadas são precárias e posicionam estas rochas nos intervalos entre micro quartzo monzonitos - micro monzogranitos e micro tonalitos - micro leucoquartzo dioritos, respectivamente. A maior dificuldade existente se refere às incertezas na origem primária, magmática, ou secundária, por alteração hidrotermal, de uma parcela do quartzo observado nas seções.

A seguir são descritas as principais características destes diferentes tipos de rocha, enfatizando suas características primárias. No Anexo 3 encontra-se uma tabela resumida dos tipos de rocha presentes na jazida. Processos e produtos de alteração serão descritos em item específico, posterior.

\section{$5.1 \quad$ Andesitos}

Estas rochas ocorrem nos perfis 1, 2 e 3 e predominam no perfil 1 (Anexo 4). Macroscopicamente, os andesitos apresentam estrutura maciça, cores variando de verde escuro a preto, em dependência do tipo de grau de alteração presente. Na maioria das amostras observa-se textura porfirítica em matriz fanerítica fina ou afanítica (Prancha 1, foto A), com uma relação modal fenocristais:matriz $=1: 2$, mas amostras mais equigranulares de granulações finas ou mesmo afaníticas também estão presentes. Nas rochas porfiríticas os fenocristais estão constituídos 
essencialmente por plagioclásio e apresentam dimensões inferiores a $3 \mathrm{~mm}$. Venulações com espessuras inferiores a $1 \mathrm{~mm}$, preenchidas por cloritas e carbonatos e com espessuras inferiores a $3 \mathrm{~mm}$, contendo feldspato potássico e quartzo são observadas em diversas amostras.

A pirita ocorre de três formas: disseminada, em finos veios e às vezes associada aos veios com cloritas e carbonatos ou com feldspato potássico e quartzo.

A descrição microscópica foi feita com base na amostra B-3, por ser esta a menos alterada do conjunto disponível. Ao microscópio, a textura é porfirítica, composta por fenocristais de plagioclásio e megacristais reliquiares de anfibólio (?) quase que totalmente substituídos, imersos em matriz com textura de tipo intergranular, composta por uma trama de cristais ripiformes de plagioclásio com biotita, magnetita e anfibólio preenchendo os espaços intersticiais (Prancha 1, foto B).

Os fenocristais de plagioclásio $\left(\mathrm{An}_{40-45}\right)$ são em geral idiomórficos e apresentam dimensões de ca. $3 \mathrm{~mm}$. A geminação polissintética da Albita, por vezes combinada com a geminação simples de Carlsbad é característica. Zonamento concêntricos, normal e oscilatório são relativamente comuns. Alguns dos fenocristais estão incipiente ou parcialmente substituídos por biotita fina e/ou sericita. Diminutos cristais de magnetita subidiomórfica a idiomórfica ocorrem como inclusões mais freqüentes. Os fenocristais de anfibólio estão quase que completamente substituídos por agregados de biotita subdiomórfica a idiomórfica, com pleocroísmo verdecastanho.

A matriz e composta por cristais subidiomorficos a idiomorficos de plagioclasio de dimensões variáveis, inferiores a 1,5 mm com hábitos ripiformes. Os espaços intersticiais são ocupados por pequenos agregados de cristais subidiomorficos de biotita $(<0,01 \mathrm{~mm})$ e, subordinadamente, por cristais de magnetita $(\cong 0,04 \mathrm{~mm})$ e tracos de anfibolio (?). Por vezes a biotita invade parcialmente os cristais de plagioclasio.

As amostras coletadas em níveis progressivamente superiores da jazida apresentam matriz micro- a cripto-cristalina, composta de diminutos grãos de quartzo e feldspatos, com menor proporção da biotita. As relações texturais sugerem que pelo menos parte da biotita que ocorre em níveis inferiores, bem como grande parte do quartzo e dos feldspatos presente na matriz do andesito a níveis superiores são de origem hidrotermal. 


\section{PRANCHA 1}

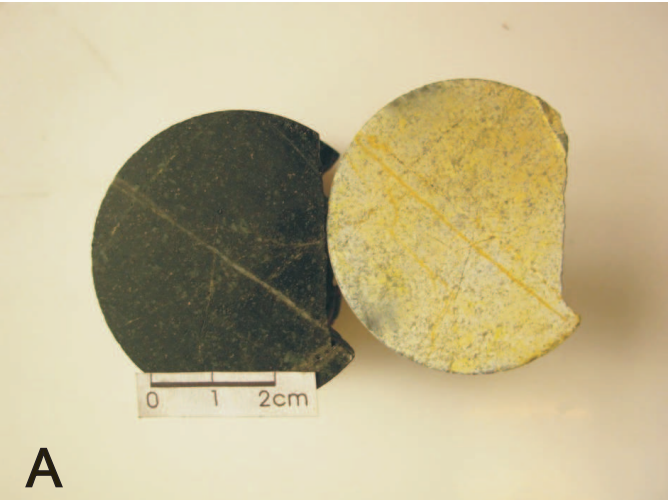

Andesito de cor preta a verde escura, com textura porfirítica, em matriz afanítica típica. À direita, fatia com tintura de cobaltonitritio de potássio (amarela) para ressaltar feldspato potássico. Notar finas venulações de feldspato potássico. Amostra D-5.

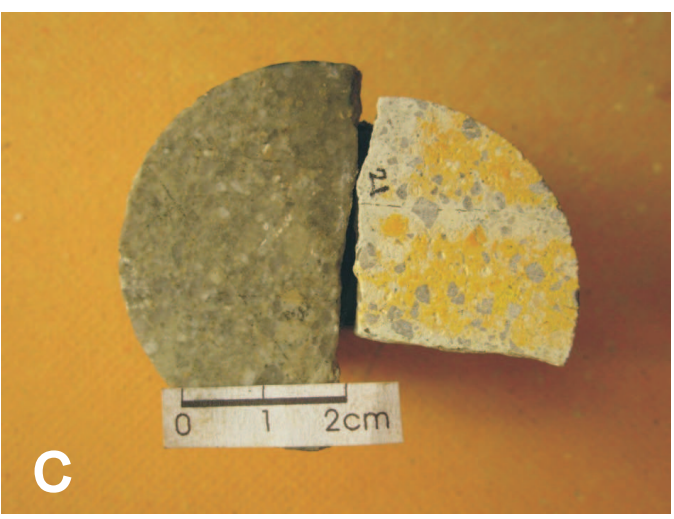

Riolito típico de cor cinza clara com textura porfirítica composta por fenocristais de quartzo e feldspatos imersos em matriz afanítica. À direita, fatia tingida ressaltando a composição potássica da matriz e o predomínio dos fenocristais de quartzo sobre os de feldspato potássico. Amostra K-2.

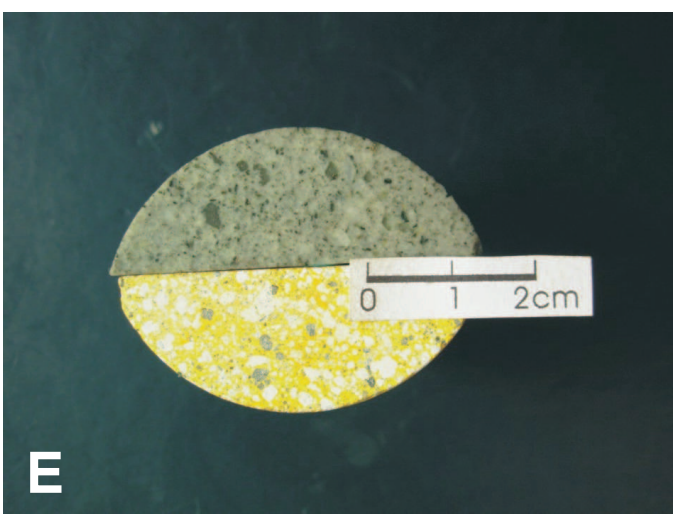

Quartzo latito típico de cor cinza esverdeada com textura porfirítica, composta por fenocristais de quartzo, feldspatos e minerais máficos verde escuros, envoltos em matriz afanítica. $\mathrm{Na}$ parte inferior fatia tingida, observa-se a predominância de feldspato potássico entre os feldspatos da matriz e dos fenocristais de plagioclásio (branco) sobre os de quartzo (cinza). Amostra R-2.

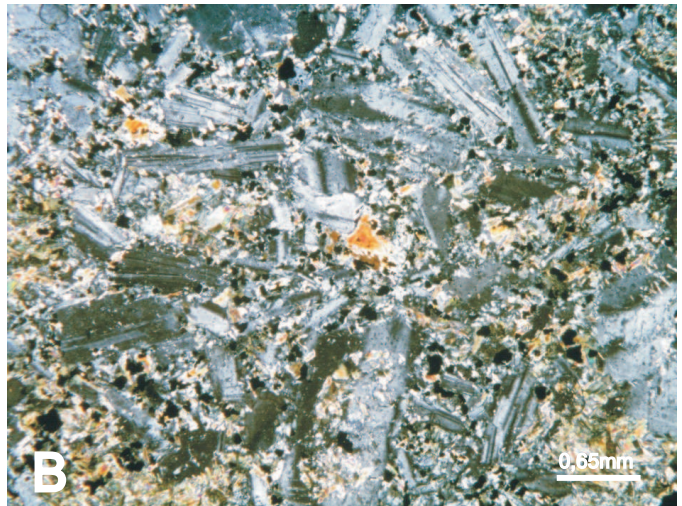

Fotomicrografia ilustrando a textura de tipo intergranular predominante na matriz da rocha, composta de cristais idiomórficos ripiformes de plagioclásio, com biotita, magnetita e anfibólio intersticiais. Polarizadores cruzados. Amostra B-3.

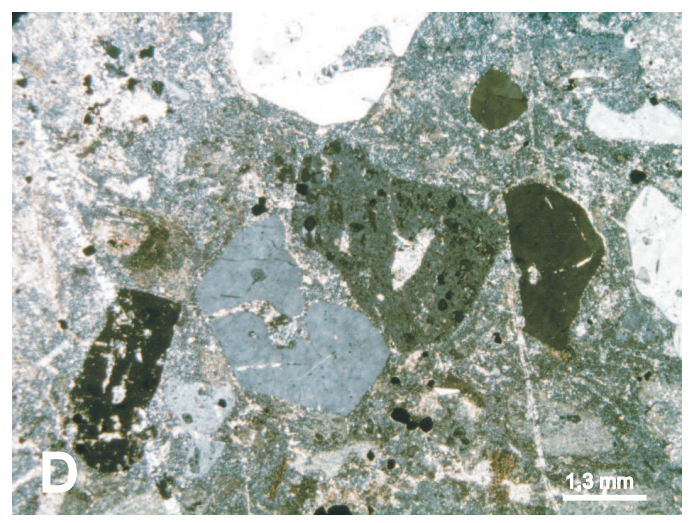

Fotomicrografia ilustrando a textura porfirítica da amostra apresentada em C. Na parte central fenocristais de quartzo (esquerda) e feldspato potássico (direita). Notar a presença de "golfos" de corrosão no quartzo. A matriz é criptocristalina, com feldspato potássico predominante entre os feldspatos. Polarizadores cruzados.

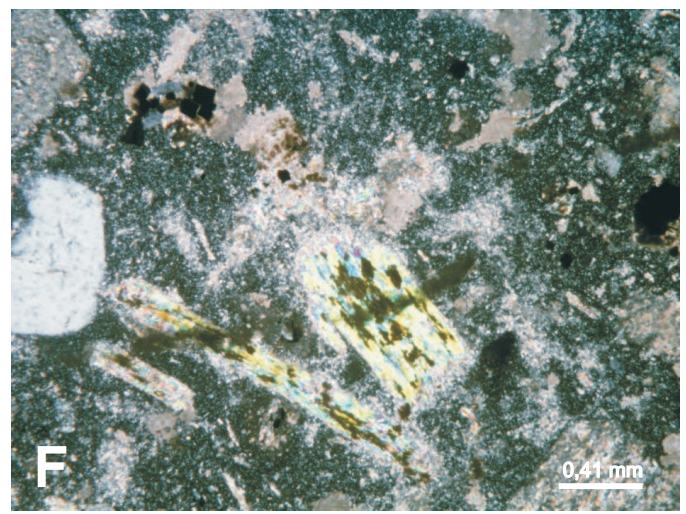

Fotomicrografia ilustrativa da textura porfirítica do quartzo latito, destacando fenocristais de quartzo (esquerda) e plagioclásio (esquina inferior direita), alguns totalmente substituídos por sericita e carbonatos, imersos em matriz criptocristalina. Moldes de fenocristais de biotita (centro) completamente substituídos por clorita, leucoxênio e epidoto. Polarizadores cruzados. 


\subsection{Riolitos}

Rochas de composição riolítica são predominantes no perfil 3 (Anexo 4). A amostra K-2 é uma das mais representativas entre as coletadas, que permite observar ainda características primárias da rocha. Macroscopicamente, esta amostra apresenta cor cinza clara e devido à alteração hidrotermal é menos compacta. A textura é porfirítica, observando-se fenocristais de quartzo, feldspatos e ocasionalmente biotita, imersos em matriz afanítica (Prancha 1, foto C).

Ao microscópio petrográfico, observa-se uma relação modal estimada de 2:5 entre fenocristais e matriz, de natureza, cripto-cristalina, bem como uma orientação de fluxo marcada pela orientação dos fenocristais e de cristais de sericita de origem hidrotermal na matriz (Prancha 1, foto D).

Os fenocristais de quartzo são predominantes e constituem entre 20 a $25 \%$ do volume da rocha. Apresentam dimensões inferiores a $3 \mathrm{~mm}$ e geralmente são idiomórficos, bipiramidados, indicando cristalização original do polimorfo de alta temperatura $(\beta)$. Alguns cristais arredondados e/ou com figuras de corrosão magmática ocorrem. Feições como leve extinção ondulante e zonas nebulosas ricas em inclusões fluidas monofásicas (solidas), bifásicas (gas-liquido) ou trifásicas, são relativamente comuns. Em algumas amostras são observados fragmentos de fenocristais de quartzo.

Os fenocristais de feldspato potássico são idiomórficos a hipidiomórfico e apresentam em geral formas tabulares. Constituem cerca de $15 \%$ em volume da rocha e apresentam dimensões médias próximas a $3 \mathrm{~mm}$. Na amostra K-2 o feldspato potássico está moderadamente substituído por minerais de argila; nas demais amostras, encontra-se forte ou totalmente substituído por agregados constituídos por minerais de argila e/ou sericita e quartzo.

Fenocristais preservados de plagioclásio não foram observados em nenhuma das amostras estudadas, mas é possível que pelo menos parte dos pseudomorfos tabulares constituídos por sericita representem cristais originais de plagioclásio. Fenocristais de biotita são escassos e em geral encontram-se totalmente substituídos, ora por cloritas e ora por muscovita; por vezes observam-se finos agregados de leucoxênio nas direções cristalográficas originais da biotita.

A matriz é criptocristalina e contém abundante feldspato potássico, a julgar pelos resultados obtidos com a coloração seletiva por cobalto nitrito de sódio (Prancha 1, foto C e D).

\subsection{Quartzo latitos}

Ocorrem nos perfis 2 e 3 (Anexo 4). A caracterização petrográfica apresentada foi feita com base principalmente na amostra R-2, do perfil 3 .

Macroscopicamente a amostra apresenta cor cinza esverdeada, estrutura maciça e textura porfirítica, com fenocristais de quartzo, feldspatos e minerais máficos embebidos em matriz afanítica de cor cinza clara (Prancha 1, foto E). 
Ao microscópio estima-se uma relação modal entre fenocristais e matriz próxima a 3:4. A matriz é também cripto-cristalina (Prancha 1, foto F) e o ensaio de coloração seletiva indica que o feldspato potássico é predominante em relação ao plagioclásio (Prancha 1, foto E).

Os fenocristais de quartzo $(0,4$ a 4,2 mm) são idiomórficos, mas também ocorrem cristais xenomórficos. Os primeiros apresentam formas bipiramidais. Figuras de corrosão são comuns; alguns mostram extinção levemente ondulante. Os fenocristais de plagioclásio (0,4-3,8 mm) correspondem a andesina $\left(\mathrm{An}_{35-40}\right)$ e são idiomórficos a subidiomórficos, apresentando formas tabulares e geminação polissintética combinada com a geminação simples de Carlsbad. Zonamento concêntrico normal também é observado.

Os fenocristais de biotita apresentam dimensões entre 0,3 e 1,5 mm, são subidiomórficos, com hábitos em "livro". Estão quase que totalmente substituídos por agregados contendo clorita, epidoto e leucoxênio, estes últimos em proporções relativamente reduzidas. Macro pseudomorfos com seções losangulares, próprias de anfibólios, constituídos por cloritas são também observados. Minerais opacos secundários aparecem associados às cloritas e desenham os planos originais de clivagem.

\subsection{Andesito II}

Andesito-II ocorre apenas no perfil 3. A amostra K-3 representa bem este tipo de rocha. Esta rocha macroscopicamente se assemelha muito aos andesitos típicos descritos, mas os resultados da coloração seletiva para feldspato potássico revelam serem rochas distintas, com proporções mais elevadas deste mineral. Entretanto, deve ser ressaltado que a análise petrográfica não permite assegurar, apesar dos esforços, que o feldspato potássico no todo ou em parte seja de origem primária e, portanto, a classificação petrográfica adotada é apenas indicativa.

Macroscopicamente apresenta cor cinza esverdeada e textura porfirítica em matriz afanítica. A quantidade de fenocristais é notadamente inferior à observada para os andesitos típicos e estes estão constituídos por plagioclásio tabular branco e máficos, com colorações pretas esverdeadas. Manchas mais claras e venulações brancas esverdeadas com espessuras aproximadas de $2 \mathrm{~mm}$ caracterizam as amostras (Prancha 2, foto A). 


\section{PRANCHA 2}

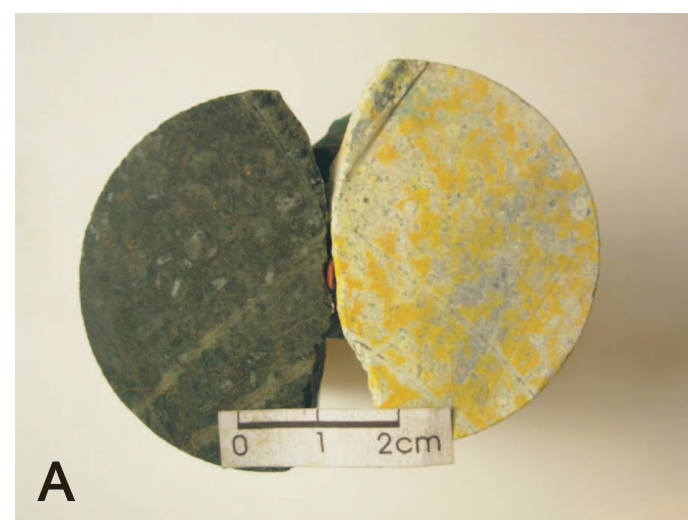

Andesito-II de cor cinza esverdeada e textura porfirítica. Notar venulações esbranquiçadas, com espessuras de até $2 \mathrm{~mm}$ que cortam a rocha de sericita-clorita. À direita, fatia tingida ilustrando teores mais significativos de feldspato potássico quando comparados aos dos andesitos mais típicos. Amostra K-3.

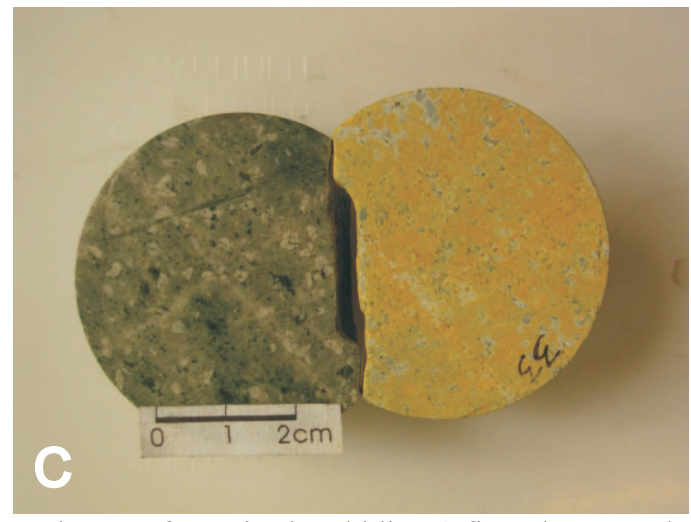

Latito com fenocristais subidiomórficos, brancos, de feldspatos imersos em matriz afanítica de cor cinza esverdeada. A fatia tingida, à direita, ilustra o predomínio de feldspato potássico tanto nos fenocristais, quanto na matriz. Amostra D-6.

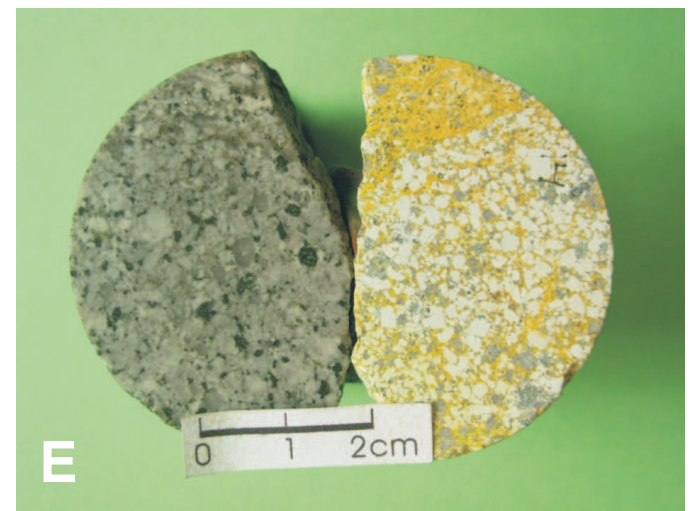

Micro-granodiorito típico, leucocrático com textura porfirítica, observando-se fenocristais de feldspatos e de minerais máficos. À direita, fatia tingida onde se verifica o predomínio de plagioclásio sobre o feldspato potássico, este último confinado na matriz da rocha. Notar, na porção superior da fatia, venulação relativamente espessa com concentração de feldspato potássico. Amostra S-3.

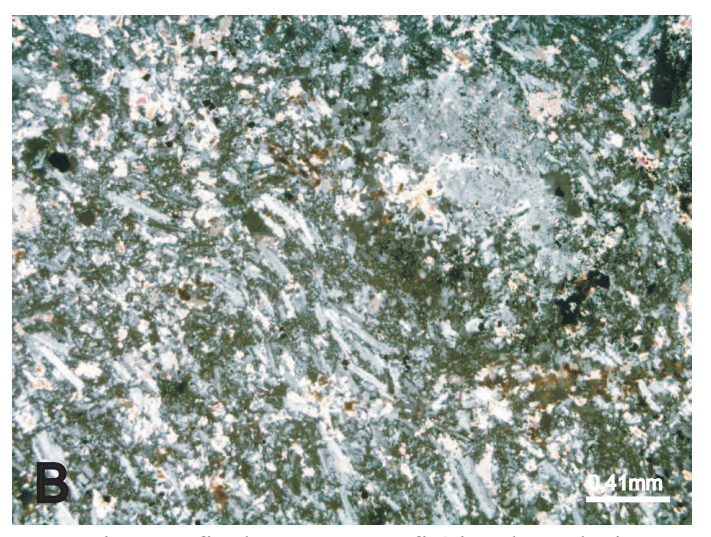

Fotomicrografia da textura porfirítica do andesito-II, ilustrando fenocristal subidiomórfico de plagioclásio em matriz com textura traquítica, composta por cristais ripiformes de feldspatos (plagioclásio e potássico) orientados. Polarizadores cruzados.
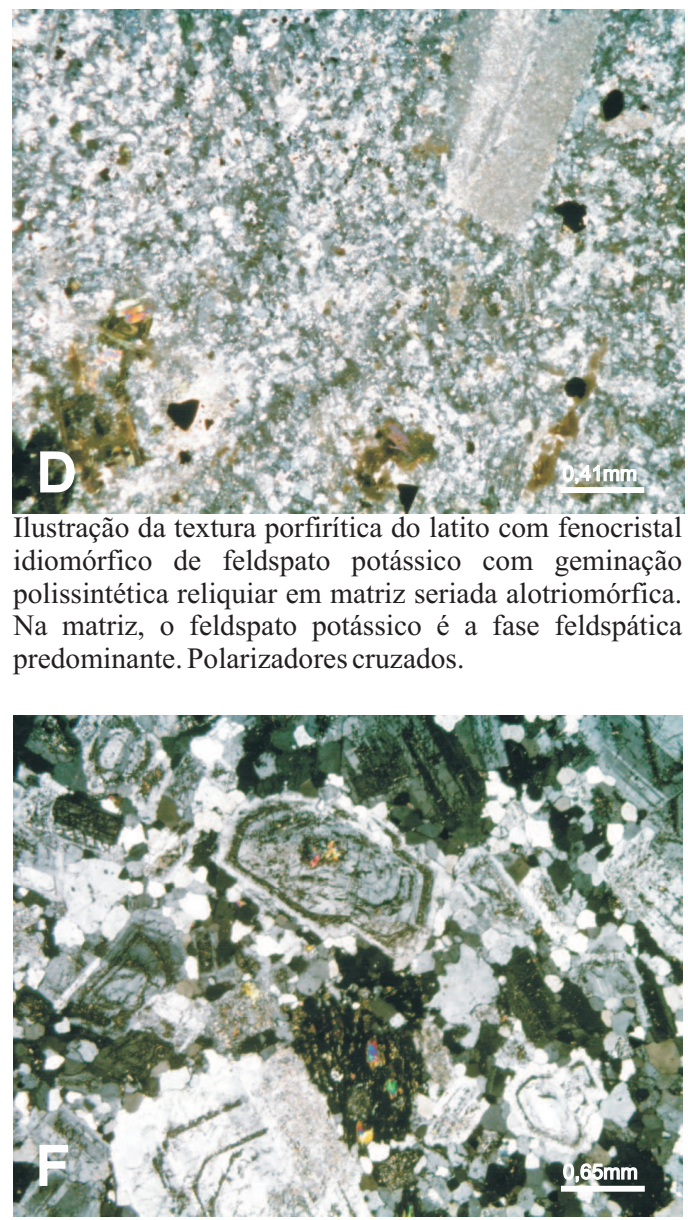

Ilustração da textura porfirítica do micro-granodiorito. Fenocristais tabulares, idiomórficos a subidiomórficos, de plagioclásio com forte zonamento composicional oscilatório, e biotita imersos em matriz microgranular alotriomórfica a hipidiomórfica, composta por plagioclásio, quartzo, feldspato potássico e minerais máficos. Polarizadores cruzados. 
Ao microscópio a relação fenocristais:matriz é da ordem de 1:3 e a matriz é tipicamente traquítica composta essencialmente de feldspatos (Prancha 2, foto B). O aspecto traquítico da matriz sugere que, de fato, parte significativa dos feldspatos seja de origem primária. O plagioclásio fenocristalino corresponde ao oligoclásio $\left(\mathrm{An}_{28-30}\right)$ e aparece idiomórfico a subidiomórfico com dimensões entre 0,3 e 0,5 mm. Apresenta geminações polissintética e de Carlsbad.

Na matriz, além de feldspatos orientados ripiformes, muito finos, com dimensões em torno de 0,12 $\mathrm{mm}$, ocorrem pseudomorfos de minerais máficos $(0,05 \mathrm{~mm})$ completamente substituídos por cloritas e óxidos de Fe. Observam-se também carbonatos e sericita, de origem hidrotermal, intersticiais aos feldspatos. Finos veios $(<2 \mathrm{~mm})$ constituídos ora por sericita predominante, ora por cloritas predominantes, cortam a amostra.

\subsection{Latito}

Estas rochas ocorrem no perfil 1 e estão representadas pela amostra D-6. A classificação destas rochas também não é tarefa simples, uma vez que pode haver dúvidas quanto à origem primária ou secundária de pelo menos parte do feldspato potássico presente.

A amostra D-6 possui estrutura maciça e textura porfirítica marcada por megacristais xenomórficos a subidiomórficos brancos, com dimensões inferiores a $2 \mathrm{~mm}$, em matriz afanítica cinza esverdeada. Estes fenocristais respondem positivamente ao ensaio de coloração seletiva para feldspato potássico (Prancha 2, foto C). Localmente a matriz apresenta manchas de tonalidades escuras, que poderiam tratar-se de feições reliquiares da rocha original.

Ao microscópio observa-se que a relação entre fenocristais de feldspato potássico e matriz é da ordem de 1:3 e estes aparecem isolados ou em grupos de diversos indivíduos, caracterizando uma textura glomero-porfirítica. A matriz é equigranular alotriomórfica, os constituintes apresentando dimensões inferiores a 0,05 mm. (Prancha 2, foto D).

Os fenocristais de feldspato potássico são subidiomórficos a idiomórficos e apresentam a geminação simples de Carlsbad, zonas difusas com possível geminação polissintética reliquiar (Prancha 2, foto D), aliada a zonas com agregados de alteração constituídos por carbonatos, cloritas, sericita e epidoto sugerem que, em parte, o feldspato potássico substitui prévios cristais de plagioclásio. Pseudomorfos de fenocristais de minerais máficos (biotita e/ou anfibólio ?), constituídos essencialmente por cloritas são ocasionais.

A matriz é composta essencialmente por feldspato potássico e, menos comumente, por quartzo, cloritas e carbonatos, os dois últimos produtos de alteração hidrotermal. Como acessório tem-se apatita que ocorre em grãos isolados euhedrais.

\subsection{Micro-granodioritos porfiríticos}

Estas rochas ocorrem no perfil 3 nas amostras T-2, T-3 e S-3. A amostra T-3 foi escolhida como representativa por estar pouco alterada. Macroscopicamente esta rocha apresenta cor 
cinza esverdeada e estrutura maciça. A textura é porfirítica, observando-se fenocristais de feldspatos que alcançam $6 \mathrm{~mm}$ e de minerais máficos, inferiores a $2 \mathrm{~mm}$ (Prancha 2, foto E).

Ao microscópio petrográfico estima-se uma relação fenocristais:matriz $=3: 2$ nas amostras S-3 e T-2. Os fenocristais são constituídos predominantemente por plagioclásio que aparecem em matriz com textura alotriomórfica a hipidiomórfica granular composta principalmente por quartzo, feldspato potássico e plagioclásio e agregados de alteração de minerais máficos (Prancha 2, foto F).

Os fenocristais de plagioclásio correspondem a andesina $\left(\mathrm{An}_{38-44}\right)$, são idiomórficos a subidiomórficos e apresentam hábitos tabulares e localmente aspecto turvo, com geminações polissintética e de Carlsbad. Apresentam zonamento composicional oscilatório. Na matriz, o plagioclásio tem dimensões médias da ordem de 0,2 $\mathrm{mm}$. O quartzo aparece como fenocristais xenomórficos esporádicos, alcançando 1,2 mm, por vezes com extinção ondulante, ou mais abundante, xenomórfico, na matriz, onde apresenta dimensões entre 0,07 mm e 0,6 mm.

Os fenocristais de feldspato potássico são relativamente raros, xenomórficos e levemente pertíticos. Na matriz, o feldspato potássico aparece intercrescido com quartzo e plagioclásio, com dimensões entre de $0,07 \mathrm{~mm}$ e $0,5 \mathrm{~mm}$.

Pseudomorfos de fenocristais biotita constituídos por clorita, epidoto e leucoxênio também são ocasionais.

\subsection{Micro-tonalitos}

Estas rochas aparecem no perfil 3 e foram caracterizadas através da amostra R-3. Macroscopicamente apresenta cor cinza esverdeada e estrutura maciça, com textura de tendência porfirítica. Observam-se cristais maiores de plagioclásio imersos em matriz fina. Veios finos (< $1 \mathrm{~mm}$ ) contendo feldspato potássico e cloritas atravessam a amostra (Prancha 3, foto A).

Ao microscópio a textura é inequigranular alotriomórfica de granulação fina com tendência a porfirítica. Os grãos maiores (até $2,6 \mathrm{~mm}$ ) são constituídos de plagioclásio, a "matriz" é formada por plagioclásio, quartzo e algum feldspato potássico, com dimensões médias da ordem de $0,8 \mathrm{~mm}$. Cloritas, carbonatos e epidoto de origem hidrotermal associam-se a estes minerais (Prancha 3, foto B). 


\section{PRANCHA 3}

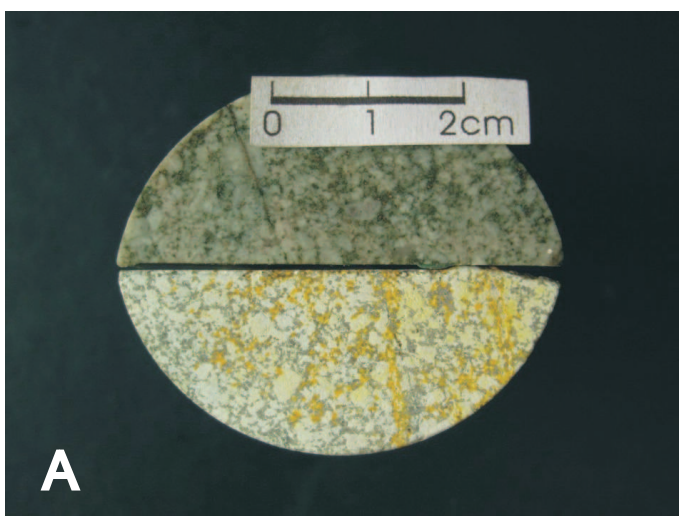

Micro-tonalito de cor cinza esverdeada com textura de tendência porfirítica, com fenocristais de plagioclásio imersos numa matriz afanítica. Notar finas venulações $(<$ $1 \mathrm{~mm}$ ) constituídas por feldspato potássico e cloritas cortando a rocha. Na fatia tingida, a coloração amarela ressalta veios e agregados de feldspato potássico, produtos de alteração hidrotermal. Amostra R-3.

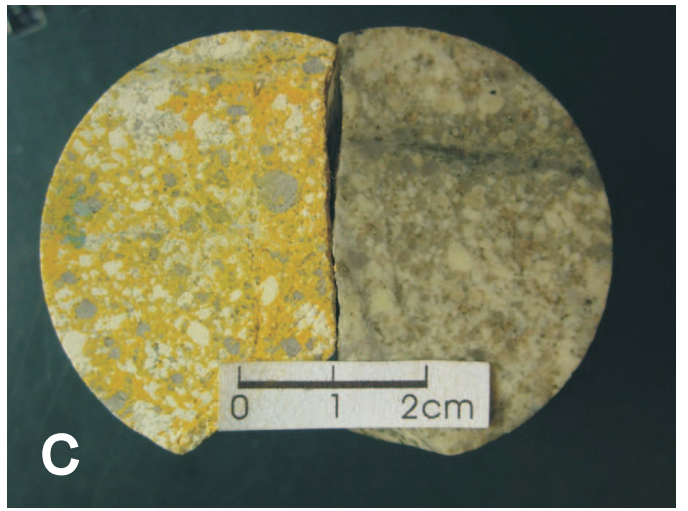

Pórfiro-I típico. Rocha com coloração cinza clara e textura porfirítica, composta por fenocristais de quartzo, feldspato potássico, plagioclásio e minerais máficos imersos em matriz afanítica. À esquerda, fatia tingida, ressaltando o predomínio do feldspato potássico na matriz. Amostra S-1.

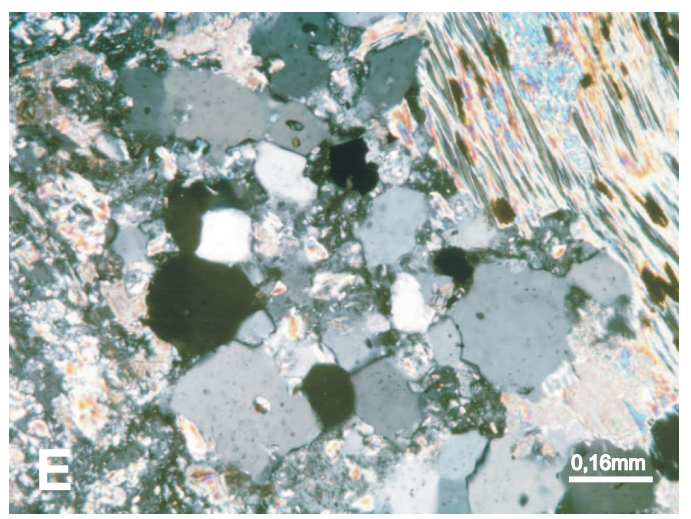

Fotomicrografia ressaltando a matriz inequigranular do pórfiro-I, composta essencialmente de feldspato potássico, quartzo e escasso plagioclásio. $\mathrm{Na}$ parte superior direita fenocristal de biotita, quase que totalmente substituído por clorita e leucoxênio. Polarizadores cruzados.

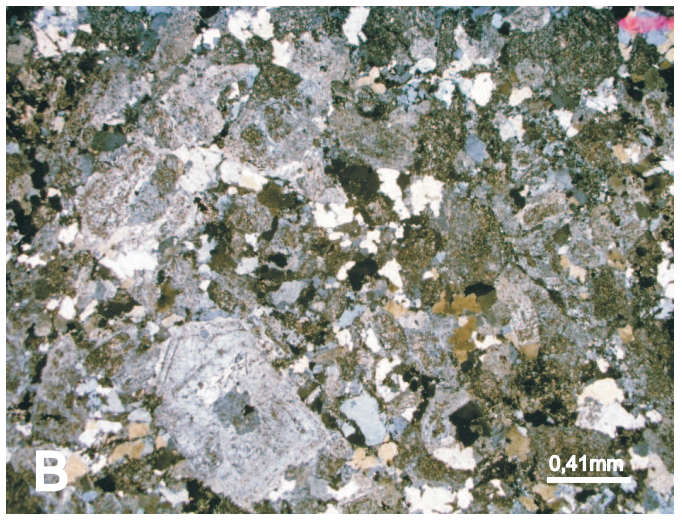

Ilustração da textura inequigranular alotriomórfica a hipidiomórfica do micro-tonalito, com tendência porfirítica (cristais maiores de plagioclásio, idiomórficos a subidiomórficos, tabulares, com zonamento oscilatório bem marcado). Polarizadores cruzados.

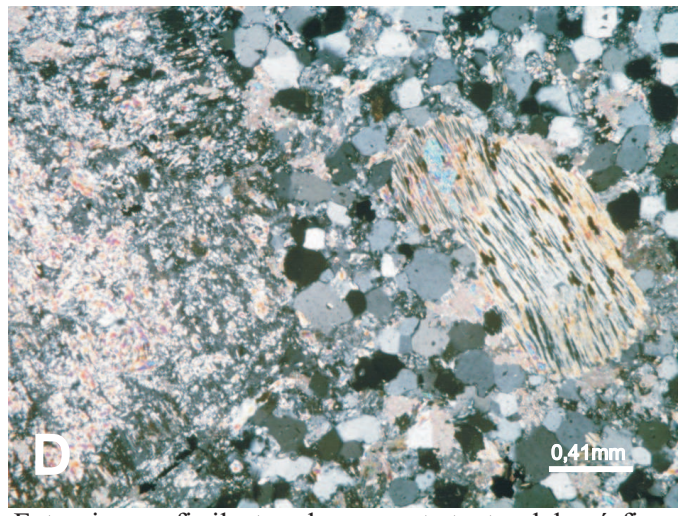

Fotomicrografia ilustrando o aspecto textural do pórfiroI, em que se observam fenocristais maiores, tabulares, de plagioclásio parcialmente alterados para sericita (esquerda) e biotita, parcialmente alterados para clorita e leucoxênio (direita) em matriz microgranular hipidiomórfica, composta por feldspato potássico, quartzo, plagioclásio e minerais máficos alterados. Polarizadores cruzados.

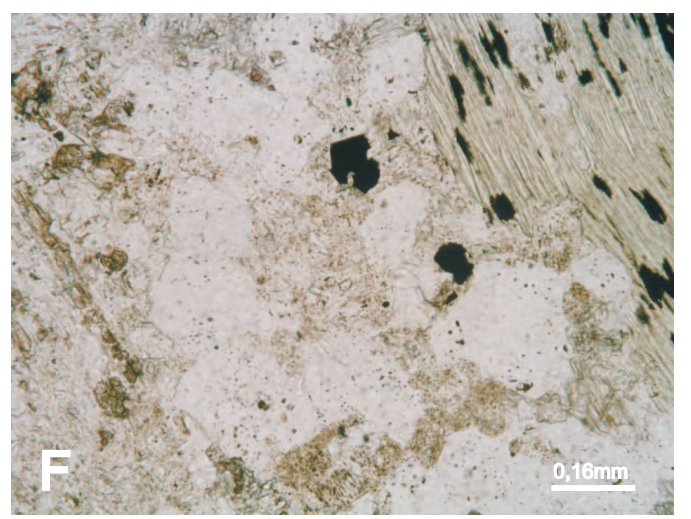

Vista da foto E com luz plano polarizada. Notar o aspecto límpido do quartzo em relação ao feldspato potássico de aparência "suja". 
O plagioclásio, tabular, subidiomórfico, corresponde a uma andesina $\left(\mathrm{An}_{30}\right)$ e mostra alteração incipiente para sericita e carbonatos; apresenta típico zonamento oscilatório. Quartzo, por vezes com extinção ondulante, e feldspato potássico são xenomórficos, este último sendo tipicamente intersticial.

Nestas rochas os minerais máficos primários não puderam ser definidos. No entanto, agregados, veios e alinhamentos curtos de cloritas junto a carbonatos, epidoto, rutilo-leucoxênio e minerais opacos de origem hidrotermal, produtos da substituição de minerais máficos, ocorrem intersticiais ao quartzo e aos feldspatos.

\subsection{Pórfiros I (micro quartzo monzonitos - micro monzograni- tos)}

São rochas maciças, porfiríticas, com matriz microgranular. A dificuldade em se contrastar quartzo de origem primária e secundária dificulta a classificação mais precisa destas rochas. As amostras P-3 e P-4, pertencentes ao perfil 3, foram consideradas as mais representativas deste grupo.

Macroscopicamente apresentam cor cinza, estrutura maciça e textura porfirítica (relação fenocristais:matriz é de 1:2). Os fenocristais de plagioclásio, quartzo e minerais máficos apresentam dimensões inferiores a 4, 3 e $1 \mathrm{~mm}$ respectivamente. A matriz é afanítica e se caracteriza pela presença de boa quantidade de feldspato potássico e pirita disseminada (Prancha 3, foto C).

Ao microscópio, a matriz é microgranular $(0,03 \mathrm{~mm}$ a $0,14 \mathrm{~mm})$, com textura alotriomórfica a hipidiomorfica e composta essencialmente de feldspato potássico, quartzo e escasso plagioclásio (Prancha 3, foto D).

Os fenocristais de plagioclásio $(0,4 \mathrm{~mm}$ a $0,34 \mathrm{~mm})$ correspondem a andesina $\left(\mathrm{An}_{33-35}\right)$, são sub-idiomórficos e ocasionalmente apresentam zonamento concêntrico oscilatório. Apresentam geminação polissintética combinada com Carlsbad e às vezes ocorrem aglutinados em dois ou três fenocristais gerando localmente a textura glomero-porfirítica. Na matriz, o plagioclásio aparece quase que totalmente substituído por sericita e carbonatos.

Os fenocristais de quartzo são escassos, corroídos, por vezes arredondados e ocasionalmente aparecem aglutinados em dois indivíduos. Na matriz, porém, as formas são anhedrais e aparecem intercrescidos com feldspato potássico (Prancha 3, foto E). Os fenocristais de biotita ocorrem substituídos parcialmente por cloritas e leucoxênio.

O feldspato potássico ocorre apenas na matriz e se apresenta límpido, xenomórfico e intercrescido com quartzo (Prancha 3, foto F). 


\subsection{Pórfiros II (micro tonalitos - micro leucoquartzo dioritos)}

Em amostras de mão os Pórfiros II, possuem textura similar ao Pórfiro I o que levou a pensar em princípio que se tratavam do mesmo tipo de rocha. No entanto, a realização da análise por pigmentação de feldspato potássico revelou apenas a presença de K-feldspato formando veios. Preliminarmente esta rocha foi classificada entre micro tonalito porfirítico e micro leucoquartzo diorito porfirítico já que o feldspato potássico não aparece na matriz da rocha. Apesar das dúvidas também sobre a origem de parte do quartzo presente na matriz, neste trabalho ele foi considerado essencialmente primário.

Esta rocha esta presente nos perfis 2 e 3 ; foram escolhidas e caracterizadas duas amostras representativas (U-3 e O-3) pertencentes ao perfil 3.

Macroscopicamente apresentam estrutura maciça, cor cinza esverdeada e textura porfirítica, com fenocristais de feldspatos e quartzo embebidos numa matriz afanítica de cor cinza. Em setores da amostra observam-se cloritas intersticiais de cor verde e lentes de quartzo hialino com formas irregulares. A pirita é escassa e ocorre disseminada. Finos veios brancos, verdes e/ou cinzentos cortam a amostra (Prancha 4, foto A).

Ao microscópio a proporção fenocristais : matriz é da ordem de 2:1. os fenocristais incluem feldspatos, quartzo e minerais máficos. A matriz é micro a criptocristalina e está composta por quartzo, predominante, e feldspato potássico subordinado (Prancha 4, foto B).

Os fenocristais de plagioclásio $(0,3-5,3 \mathrm{~mm})$ situam-se no intervalo composicional da andesina $\left(\mathrm{An}_{29-33}\right)$ e são subidiomórficos a idiomórficos, com hábitos tabulares. Aparecem isolados ou em agregados de alguns cristais, caracterizando a textura glomero-porfirítica. A geminação é do tipo polissintética combinada com Carlsbad e, por vezes, combinada com geminação do periclíneo. Zonamento concêntrico oscilatório é comum. Na matriz aparecem xenomórficos, intercrescidos com quartzo e subordinadamente feldspato potássico. Substituição para sericita, carbonatos e epidoto é incipiente.

Os fenocristais de quartzo $(0,6$ - 4,6 mm) são subidiomórficos a arredondados, por vezes com formas bipiramidadas, com extinção ondulante leve e, ocasionalmente figuras de corrosão. Na matriz é xenomórfico, apresentando dimensões inferiores a 0,4 mm.

Os minerais máficos aparecem totalmente substituídos, observando-se pseudomorfos tabulares $(1,01,5 \mathrm{~mm})$ constituídos por cloritas às vezes associadas a epidoto e leucoxênio. A amostra U-3 não apresenta estes pseudomorfos. Na matriz, os máficos primários também se encontram substituídos por pequenos agregados de cloritas junto a carbonatos e epidoto. 


\section{PRANCHA 4}

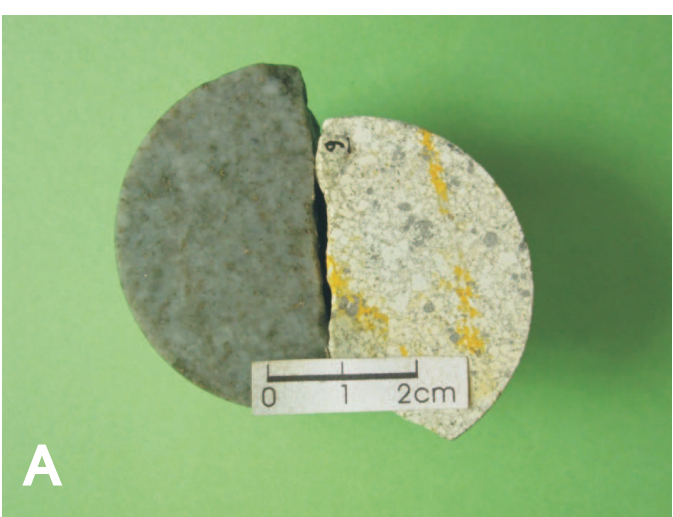

Pórfiro-II típico. Rocha de cor cinza esverdeada e textura porfirítica, composta por fenocristais de feldspato imersos em matriz micro a criptocristalina composta por quartzo e feldspatos. À direita, fatia tingida ressalta venulações de feldspato potássico cortando a amostra. Amostra U-3.

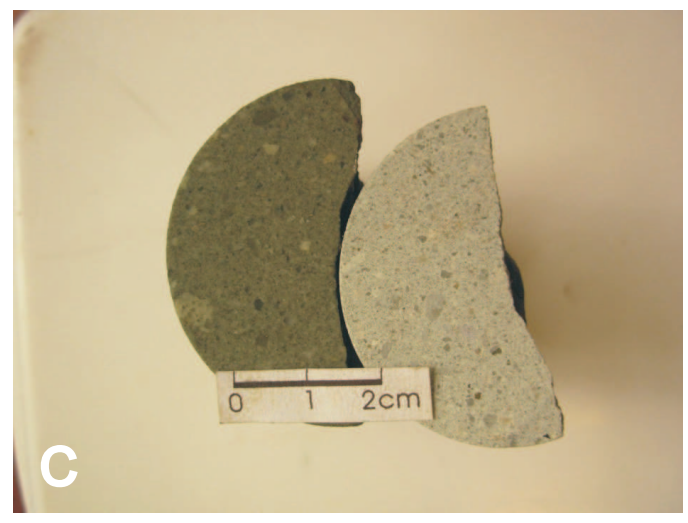

Microbrecha com clastos angulosos a subarredondados de quartzo $(<2 \mathrm{~mm})$, feldspatos $(<2 \mathrm{~mm})$ e fragmentos líticos $(<5 \mathrm{~mm})$ imersos em matriz afanítica. À esquerda, fatia tingida, destacando a escassez de feldspato potássico. Amostra H-3.

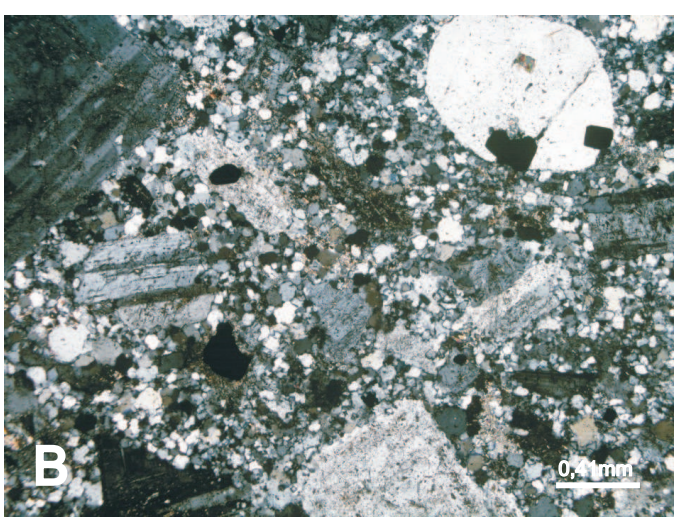

Fotomicrografia ilustrando a textura porfirítica do pórfiro II e destacando os fenocristais de plagioclásio tabulares, idiomórficos a subidiomórficos, com zonamento composicional oscilatório, quartzo arredondado e moldes de minerais máficos completamente substituídos por cloritas, epidoto e leucoxênio em matriz micro/criptocristalina composta por quartzo, feldspatos e minerais máficos alterados. Polarizadores cruzados.

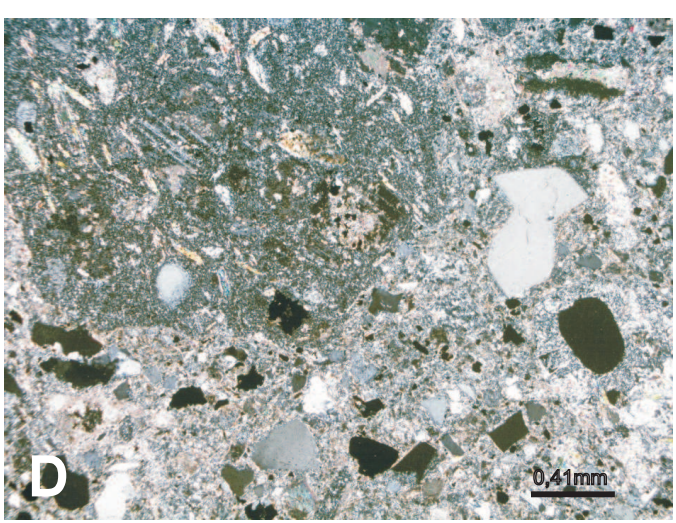

Fotomicrografia ilustrando clastos líticos (lado superior esquerdo) de quartzo e fenocristais de quartzo subidiomórficos. Relictos de fenocristais tabulares, completamente substituídos por quartzo e sericita (lado inferior direita), provavelmente representam produto de substituição de plagioclásio. Polarizadores cruzados. 
O zircão ocorre como mineral traço, em grãos isolados idiomórficos, com dimensões de aproximadamente $0,10 \mathrm{~mm}$.

\subsection{Micro-brecha}

Esta rocha ocorre no perfil 2 sendo representada pela amostra H-3. Macroscopicamente apresenta cor cinza e estrutura maciça onde se observa clastos angulosos de quartzo $(<2 \mathrm{~mm})$ e, subordinadamente, de feldspatos $(<2 \mathrm{~mm})$ e fragmentos líticos $(<5 \mathrm{~mm})$ imersos numa matriz afanítica (Prancha 4, foto C).

Ao microscópio, além dos clastos, são observados pseudomorfos com formas tabulares e tendência ao idiomorfismo constituídos por sericita e quartzo, provavelmente produtos de substituição de fenocristais de plagioclásio (Prancha 4, foto D).

Os clastos líticos são relativamente escassos e apresentam dimensões que alcançam 0,3 mm. As formas são angulosas a sub-angulosas e a sua constituição sugere tratar-se de fragmentos de andesitos e, aparentemente, riodacitos e tufos. Moldes de clastos completamente substituídos por carbonatos, sericita-quartzo, cloritas e quartzo são ocasionais. Os clastos encontram-se bem fraturados.

A matriz cripto- a microcristalina é constituída por sericita fina e carbonatos. Localmente a sericita aparece intensamente orientada, evidenciando o fluxo primário da rocha. 



\section{6}

\section{Alterações Hidrotermais}

\subsection{Caracterização e tipologia}

A alteração hidrotermal compreende processos complexos que envolvem transformações texturais, mineralógicas e químicas da rocha original, resultantes da sua interação com fluidos aquosos quentes, sob determinadas condições físico-químicas (Pirajno, 1992).

As assembléias mineralógicas encontradas em depósitos do tipo greisen, skarn e porphyry copper permitem identificar tipos contrastados de alteração hidrotermal. De acordo com Pirajno (1992), as alterações hidrotermais podem ser reunidas em 5 grupos principais: metassomatismo alcalino, alteração propílica, alteração fílica, alteração argílica e outros tipos. A seguir apresentam-se uma breve caracterização de cada um destes grupos, baseada nos trabalhos de Meyer \& Hemley (1967), Pirajno (1992) e Townley (2001).

\section{Metassomatismo alcalino}

O denominado metassomatismo alcalino inclui os tipos sódico (albitização) e potássico e ambos resultam da interação de fluídos residuais da cristalização recente do magma com a rocha recém cristalizada e com as rochas encaixantes. O primeiro caso poderia ser caracterizado como um auto-metassomatismo, uma vez que haveria pouca ou nenhuma participação de fluídos meteóricos (Pirajno, 1992); já no caso do metassomatismo potássico, os fluídos meteóricos teriam uma contribuição significativa (Hemley et al., 1980) e este ocorreria em ambientes mais frios que a albitização, sendo portanto posterior.

A mineralogia associada à albitização é caracterizada pela presença de albita, em geral 
pura. A alteração potássica, por sua vez, é caracterizada pelo desenvolvimento de feldspato potássico (em geral microclínio) e/ou biotita, acompanhados por quartzo, magnetita, sericita

e clorita. É interessante notar que, no início do processo de alteração, a hornblenda primária é substituída por agregados e/ou glomérulos de cristais de biotita com composições similares a da biotita primária, com freqüência denominada de textura hornfélsica (e.g. Townley, 2001).

Segundo Townley (2001) a alteração potássica de mais alta temperatura (400 a $800{ }^{\circ} \mathrm{C}$ ) é caracterizada por ser seletiva e penetrativa. Biotita em veios ocorre entre $350-400{ }^{\circ} \mathrm{C}$ e feldspato potássico em veios entre $300-350{ }^{\circ} \mathrm{C}$. Em geral, tanto a biotita quanto o o feldspato potássico são formados em condições de $\mathrm{PH}$ neutro a alcalino.

\section{Alteração Propílica}

Este tipo de alteração é caracterizado pela assembléia formada por clorita, epidoto, albita, calcita, pirita e minerais acessórios como quartzo, magnetita e illita. Este tipo de alteração ocorre geralmente formando halos gradativos e distais em relação à alteração potássica, observandose por vezes uma assembléia com actinolita-biotita no contacto da zona potássica que passa progresivamente para actinolita-epidoto na zona propílica.

Esta alteração se forma em condições de $\mathrm{pH}$ neutro a alcalina, sob temperaturas mais baixas, entre $200-250{ }^{\circ} \mathrm{C}$ (Townley, 2001). Nas zonas distais observam-se associações de epidoto, clorita, albita e carbonatos graduando a zonas progressivamente mais ricas em clorita e zeólitas formadas sob condições de temperatura inferior. Em algumas áreas tem-se o desenvolvimento acentuado de albita, clorita, zeólitas e carbonatos, que Meyer \& Hemley (1967) preferem tratar separadamente como variações da alteração propílica.

\section{Alteração Fílica}

Esta alteração é reconhecida pela assembléia sericita-quatzo dominada pela sericita enquanto que a alteração quartzo-sericítica é dominada pelo quartzo; clorita, illita e pirita aparecem associadas em quantidades acessórias. Em ambientes ricos em Na, paragonita aparece como a mica branca dominante. Variedades de micas ricas em V (roscoelita) e Cr (fuchsita) ocorrem localmente em zonas alteradas de rochas máficas. Pirajno (1992) e Meyer \& Hemley (1967) reúnem sob a designação sericita quaisquer micas brancas finas, incluindo muscovita, paragonita, phengita, fuchsita e roscoelita. De fato, sericita é um termo petrográfico utilizado para designar qualquer material micáceo incolor, de granulação fina e de birrefringência de segunda ordem (c.f. Inoue, 1995). Esta alteração ocorre a temperaturas acima de $250{ }^{\circ} \mathrm{C}$ e pH entre 5 a 6. Sob temperaturas mais baixas se forma illita $\left(200-250{ }^{\circ} \mathrm{C}\right)$ ou mesmo illita-smectita (100 $-200{ }^{\circ} \mathrm{C}$ ) (Townley, 2001). 


\section{Alteração Argílica}

A alteração argilica é identificada pelo desenvolvimento de argilo-minerais e caracteriza ambientes relativamente mais ácidos ( $\mathrm{pH}$ entre 4 e 5), quando comparada com a alteração fílica. São diferenciados dois tipos: argilização intermediária e avançada. Segundo Townley (2001) a primeira é caracterizada pela presença de minerais de argila, especialmente caolinita (em geral formada abaixo de $300{ }^{\circ} \mathrm{C}$ ), e quartzo em maior ou menor quantidade e ocorre sob condições de $\mathrm{pH}$ entre 3 e 4 . A segunda é identificada principalmente pela presença de quartzo residual (vuggy sílica) que freqüentemente está associado à alunita, jarosita, caolinita, pirofilita (formada acima de $300{ }^{\circ} \mathrm{C}$ ) e pirita. Ocorre sob condições de $\mathrm{pH}$ entre 1 e 3,5 ; alunita e quartzo são as fases dominantes sob condições de $\mathrm{pH}$ acima e abaixo de 2, respectivamente.

\section{Outras alterações}

A silicificação é a mais importante das outras alterações hidrotermais. E caracterizada pelo enriquecimento em sílica e formação de quartzo $\alpha$, calcedônia e opala sob temperaturas baixas e quartzo $\beta$, tridimita e cristobalita sob temperaturas mais altas (Pirajno, 1992)). Nos processos mais típicos de baixa temperatura, a sílica pode ser introduzida por fluidos relativamente ácidos ou concentrar-se pela lixiviação de bases que resultam em sílica residual.

O reconhecimento de processos de silicificação por vezes não é tarefa simples, dada a dificuldade comum de contrastar quartzo de origem primária ou secundária e a geração de quartzo também como produto dos outros tipos de alteração em seções petrográficas. Neste trabalho, quase todas as amostras apresentam algum quartzo de origem hidrotermal, porém, apenas nos casos onde este é mais abundante e típico, a alteração foi considerada silicificação.

\section{Intensidade das alterações hidrotermais}

A intensidade dos fenômenos de alteração hidrotermal é avaliada de acordo com o grau de preservação da rocha original. Pirajno (1992) subdivide as alterações hidrotermais em graus decrescentes de intensidade em alterações pervasivas, seletivamente pervasivas e fissurais.

Nas alterações pervasivas, a mineralogia e a textura da rocha original encontram-se total ou, pelo menos, significativamente transformadas. No segundo caso, a substituição é seletiva e ocorre em determinados minerais da rocha original, cuja textura encontra-se em geral preservada. No último caso, os minerais de alteração se concentram tipicamente em veios, em geral preenchendo fraturas, e nas zonas imediatamente vizinhas da rocha encaixante, por vezes afetando-a ao longo de diversos centímetros.

Os termos incipiente, fraca, moderada, forte e pervasiva ainda são utilizados com muita freqüência nos trabalhos expeditos. 


\subsection{Alterações hidrotermais na jazida Cuajone}

Nas rochas estudadas da jazida de Cuajone, as alterações hidrotermais ocorrem em diferentes intensidades. Por facilidade de descrição, estas alterações foram classificadas em incipientes, fracas, moderadas, fortes e pervasivas (muito fortes). A tipologia e as características mais relevantes das alterações presentes são descritas a seguir para os principais tipos de rocha identificados; uma síntese, destacando as assembléias minerais descritas, é apresentada no Anexo 5; diagramas dos três perfis elaborados com os diferentes tipos de alteração presentes são apresentados no Anexo 6.

\subsubsection{Andesitos}

Os andesitos apresentam três tipos principais de alteração: potássica, propílica e silicificação, com relações mútuas em geral gradativas.

A alteração potássica é caracterizada pela presença de biotita e, subordinadamente, feldspato potássico, aos quais se associam anidrita, gipsita, sericita e quartzo (Prancha 5, foto A).

A biotita (ca. 0,05 mm), ocorre como agregados de grãos idiomórficos associados e/ou intercrescidos com plagioclásio (a), substituindo parcialmente fenocristais de feldspatos (b), substituindo pervasivamente minerais da matriz da rocha (c) e em finas venulações (d). No caso (a) a separação ao microscópio petrográfico entre biotita primária e hidrotermal mostrouse muito difícil; na amostra B-3, parte significativa desta geração de biotita deve ser secundária devido à sua ocorrência e tonalidades de pleocroísmo entre verde a fracamente marrom. Agregados de cristais idiomórficos de biotita, lembrando a textura hornfélsica, comuns nas amostras C-4, D-3, E- 3, G-1, V-1 e em partes da amostra C-3, sugerem uma origem através de alteração potássica sobre anfibólios primários.

O feldspato potássico é mais raro, aparecendo mais tipicamente em veios, não se associando à biotita. Algumas vezes forma intercrescimentos irregulares com quartzo (Prancha 5, foto A).

A anidrita ocorre disseminada (Prancha 5, foto B) e em finos veios, por vezes intercrescida com quartzo e gipsita. A sericita é incipiente como produto da alteração de plagioclásio.

A alteração propílica está representada pelo desenvolvimento de cloritas, carbonatos e epidoto, associados eventualmente com minerais de argila, quartzo e traços de biotita, leucoxênio e magnetita (prancha 5, foto C e D). As cloritas ocorrem intersticiais aos plagioclásios da matriz, substituindo fenocristais de minerais máficos e mesmo parcialmente de feldspatos, em veios e agregados. Carbonatos, epidoto e leucoxênio quase sempre estão associados. 


\section{PRANCHA 5}

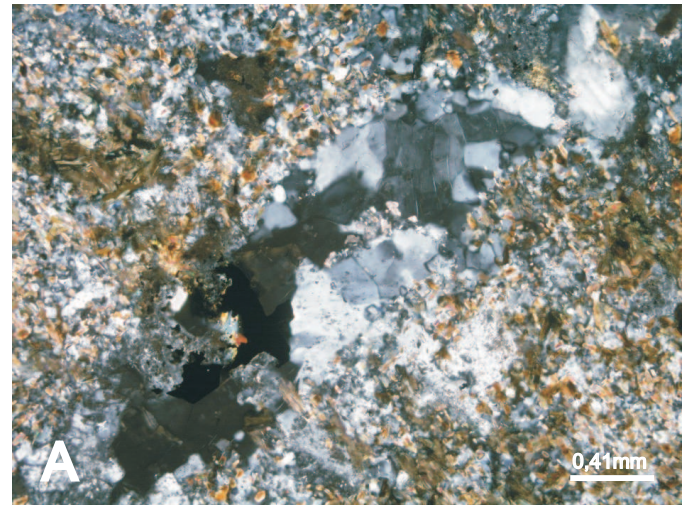

Fotomicrografia mostrando veio de feldspato potássico intercrescido com quartzo e minerais opacos (negro) cortando a amostra de andesito. Biotita de origem hidrotermal, localmente substituída por clorita, comum na matriz da rocha. Alteração potássica moderada a propílica débil. Polarizadores cruzados. Amostra D-5.

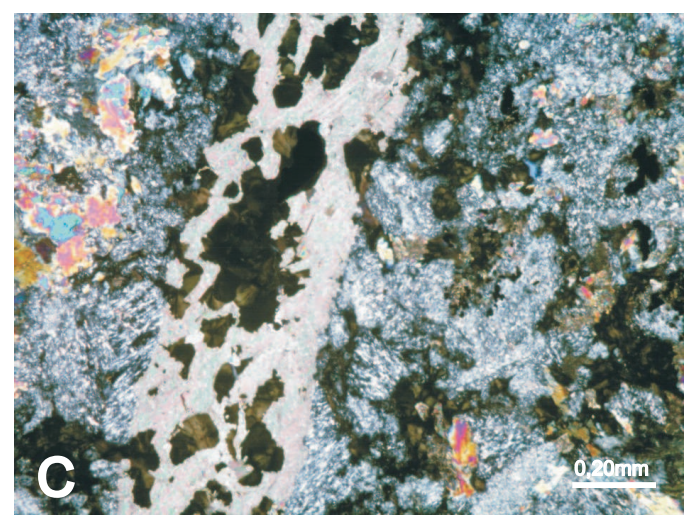

Fotomicrografia ressaltando a alteração propílica em andesito, representada por cloritas (agregados irregulares e venulação), carbonatos (venulação), epidoto (parte superior-esquerda da imagem) e, subordinadamente, minerais de argila e sericita, produtos da substituição quase completa dos feldspatos da rocha original. Polarizadores cruzados. Amostra G-3.

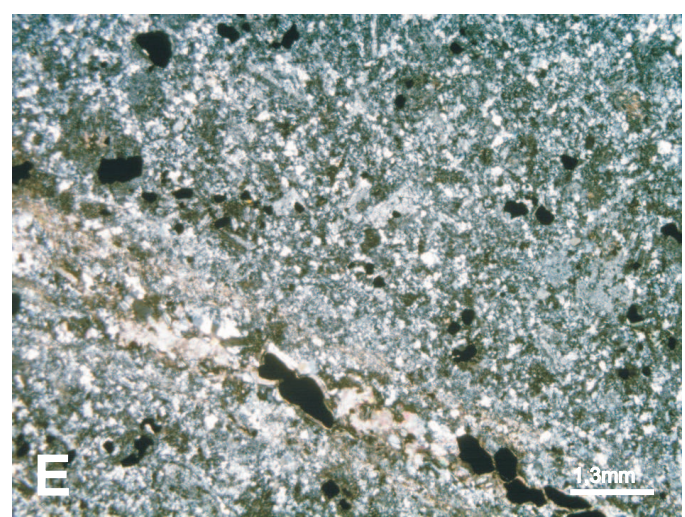

Andesito silicificado, apresentando quartzo de natureza hidrotermal instersticial a plagioclásio ripiforme. Notar venulação constituída por carbonatos, epidoto, minerais opacos e quartzo, cortando a amostra e indicando alguma alteração propílica. Polarizadores cruzados. Amostra M4.

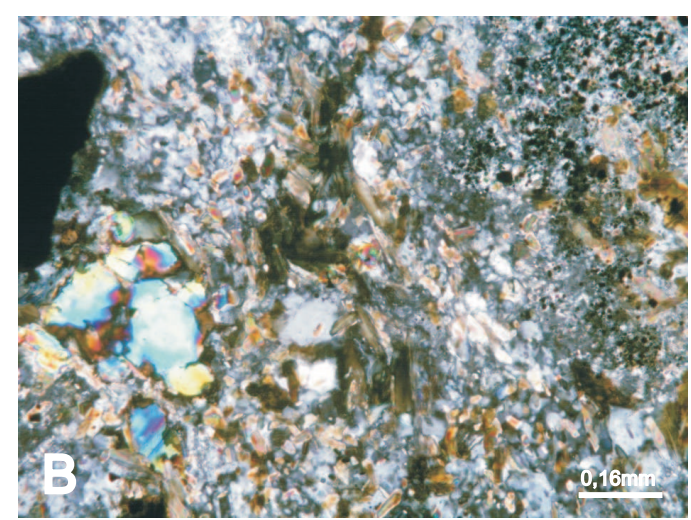

Fotomicrografia ilustrando a ocorrência de anidrita em agregado de três indivíduos, à esquerda da imagem. $\mathrm{Na}$ parte central, cristais de biotita completamente substituídos por cloritas. Na parte superior direita, disseminações de magnetita (negro). Alteração potássica a propílica débil. Amostra D-5.

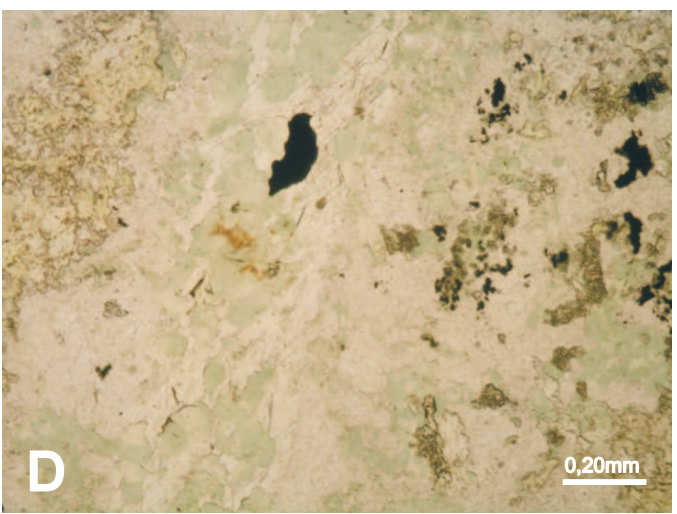

Idem C, sob luz plano polarizada, destacando veio formado por cloritas, carbonatos e epidoto. Opaco (negro) junto a veio.

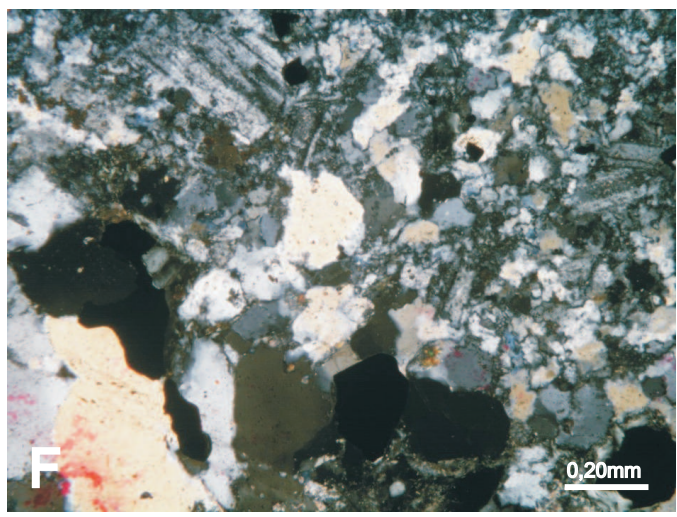

Detalhe da imagem E, destacando quartzo de origem hidrotermal dispostos em agregados entre os grãos de plagioclásio. Na parte inferior esquerda, venulação contendo quartzo e minerais opacos. Polarizadores cruzados. 
Os minerais de argila aparecem ora na matriz, associando-se com sericita, carbonatos e algum quartzo, ora nos pseudomorfos de fenocristais de feldspatos (amostras A-1, C-2 e D-2). A sericita também ocorre nestes pseudomorfos associada à grãos diminutos, idiomórficos, de magnetita $(<0,04 \mathrm{~mm})$, outras vezes associada a carbonatos e cloritas e ainda preenchendo veios junto com quartzo. O quartzo aparece em agregados de diversos cristais e em veios, junto com cloritas, carbonatos, epidoto e minerais opacos. Biotita é escassa.

A silicificação é mais típica das amostras B-2, M-4 (Prancha 5, foto E, F) e R-4 e se desenvolve na forma de agregados na matriz da rocha e em veios. Entretanto, vale a pena mencionar que nas amostras C-1, D-5, E-1, E-2, F-2, F-3 e M-5, a medida que se avança a níveis topográficos superiores, a presença de quartzo, quase criptocristalino, na matriz da rocha aumenta.

Em todas estas alterações observam-se, ocasionalmente, veios preenchidos de um mineral não identificado, incolor, com baixa birrefringência e baixo índice de refração, caracterizado preliminarmente como um mineral do grupo das zeólitas, as quais são mais típicas da alteração potássica.

Os minerais opacos mais freqüentes encontrados nas diversas alterações desta rocha são magnetita, pirita e calcopirita. Molibdenita e rutilo-leucoxênio também estão presentes, mas só em algumas amostras (Anexo 5).

\subsubsection{Riolitos}

Os riolitos descritos na jazida foram afetados essencialmente pela alteração fílica, observandose o desenvolvimento típico de sericita e quartzo, acompanhados por quantidades menores de argilo-minerais, rutilo e/ou leucoxênio e, por vezes, muscovita. A textura porfirítica original destas rochas foi quase que totalmente obliterada pela alteração, caracterizando um estilo pervasivo (grau muito forte), que confere à rocha uma coloração esbranquiçada característica (Prancha 6, foto A).

Os fenocristais de feldspato potássico e de plagioclásio foram completamente substituídos por sericita-quartzo ou sericita-quartzo-leucoxênio e outros só por argilas resultando em textura porfiritica pseudomórfica (Prancha 6, foto B). Macrocristais lamelares de muscovita são identificados como produto da substituição dos minerais máficos. Estes cristais por vezes podem ter leucoxênio paralelos aos planos cristalográficos.

A matriz está substituída por sericita-quartzo, minerais de argila e leucoxênio. A sericita por vezes é muito fina e confunde-se com minerais de argila (amostras K-1, L-1, L-2, L-3 e N-1). Em algumas amostras (K-1, L-2, M-2 e N-1), parte da sericita da matriz marca direções originais de fluxo magmático e em outras apresentam aspecto mais tipicamente massivo (amostras L-1, L-3 e M-1).

Veios de quartzo-sericita aparecem tipicamente intercrescidos com minerais opacos (Prancha 6 , foto $\mathrm{C}$ ), dentre os quais foram identificados pirita, calcopirita e rutilo-leucoxênio em 
maiores quantidades e bornita, covelita, calcosita e aparentemente cobre cinza em quantidades subordinadas.

\subsubsection{Quartzo latito}

Estas rochas (amostras I-1, -2, -3, -4, A-2, A-3 e R-2) apresentam alteração propílica fraca caracterizada por cloritas, carbonatos, sericita e epidoto. Em algumas amostras foi observado predomínio de sericita (I-3 e I-4) e em outras carbonatos (I-1, I-2, A-2 e A-3).

Nestas rochas, os fenocristais de minerais máficos (biotita e, as vezes, anfibólio) estão substituídos por cloritas, epidoto e leucoxênio (Prancha 1, foto E). Em algumas amostras a biotita foi completamente substituída por muscovita. Os fenocristais de plagioclásio encontramse fracamente substituídos por carbonatos, argilas, sericita e epidoto (Prancha 6, foto D), assim como parte da matriz da rocha em algumas amostras. Pirita e calcopirita ocorrem disseminadas e associadas aos agregados de cloritas, carbonatos e epidoto. Magnetita, hematita e rutiloleucoxênio também estão presentes.

\subsubsection{Andesito II}

Esta rocha, representada pela amostra K-3, apresenta alteração principalmente propílica, mas parte menor do feldspato potássico observado pode ser também de origem hidrotermal (e.g., Prancha 2, foto A). A alteração propílica foi caracterizada pela identificação de diminutos cristais de carbonatos e sericita, que substituem fenocristais de feldspatos (geralmente plagioclásio). Na matriz também se observam carbonatos, pequenos agregados de cloritas e de quartzo, os quais ocorrem associados ou mesmo intercrescidos com os feldspatos da rocha. Veios de sericita, quartzo e minerais opacos também são observados (Prancha 6, foto E).

Os minerais opacos identificados são: pirita, calcopirita, magnetita-hematita e rutilo-leucoxênio. Geralmente a magnetita ocorre em diminutos cristais euhedrais disseminados nos fenocristais de feldespatos (plagioclásio).

\subsubsection{Latito}

Esta rocha, representada pela amostra D-6, apresenta alterações propílica moderada a potássica fraca. A alteração propílica é caracterizada pela substituição completa dos minerais máficos por cloritas, carbonatos, sericita e epidoto (Prancha 6, foto F) e parcial dos fenocristais de feldspatos (plagioclásio).

Na matriz também se observam cloritas e carbonatos intersticiais ao feldspato potássico e quartzo primários. 


\section{PRANCHA 6}

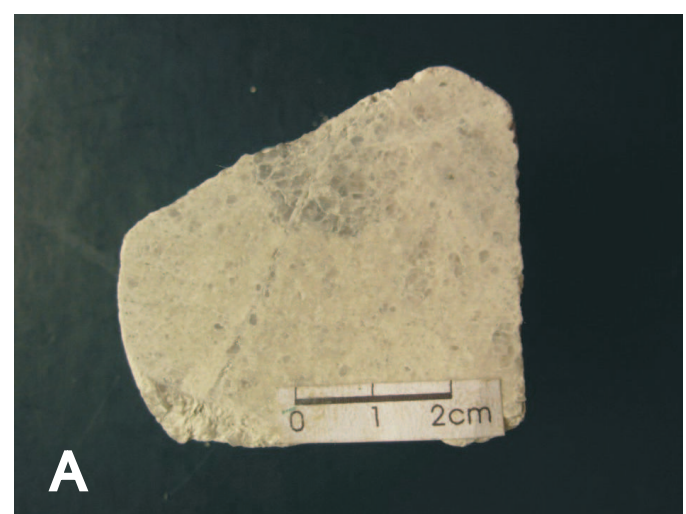

Riolito, quase que completamente transformado por alteração fílica (sericitização). Notar aspecto esbranquiçado da amostra e venulação de sericita e quartzo-sericita. Amostra L-1.

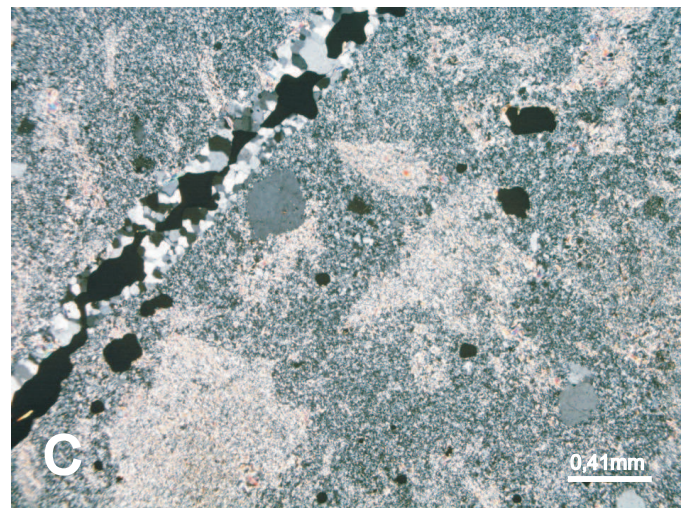

Fotomicrografia de riolito com alteração fílica pronunciada. Notar veio de quartzo e minerais opacos, alguns fenocristais subidiomórficos de quartzo e relictos de fenocristais de feldspatos totalmente substituídos por sericita. Polarizadores cruzados. Amostra N-1.

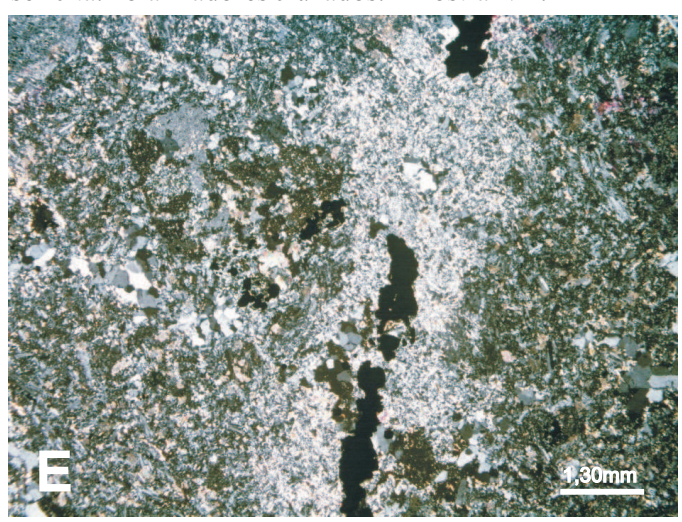

Fotomicrografia do andesito-II, ilustrando venulação composta por sericita, quartzo e minerais opacos. A matriz também esta sendo substituída por carbonatos, cloritas e quartzo destacando a alteração propílica. Parte do feldspato potássico na matriz pode ser também de origem hidrotermal destacando débil alteração potássica. Polarizadores cruzados. Amostra K-3.

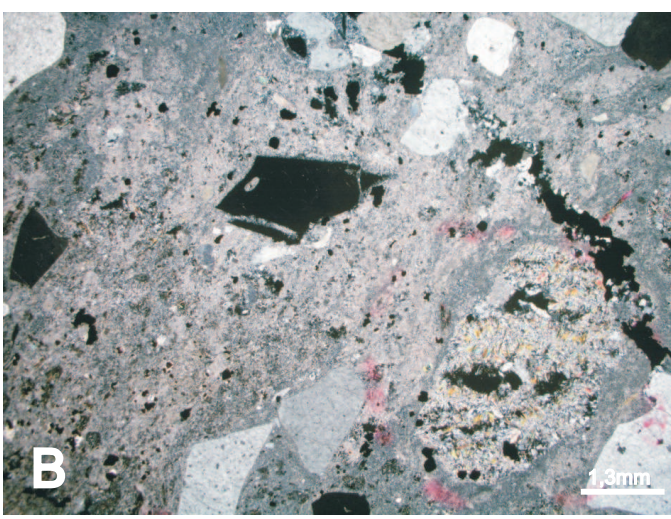

Fotomicrografia de riolito com alteração fílica. Fenocristais de quartzo e macro pseudomorfos compostos principalmente por sericita, quartzo, leucoxênio e minerais de argila, imersos em matriz criptocristalina parcialmente sericitizada. Notar venulação de pirita (negro). Polarizadores cruzados. Amostra M-3.

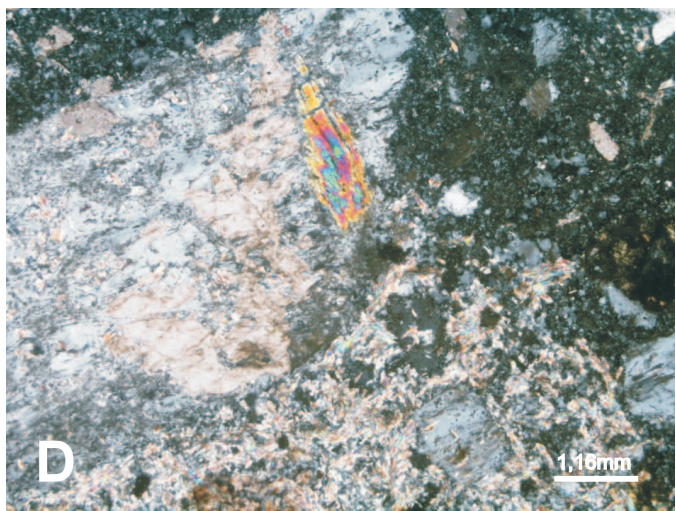

Fotomicrografia de quartzo-latito, destacando a substituição parcial de fenocristal de plagioclásio por carbonato, epidoto e sericita. Polarizadores cruzados. Amostra I-4.

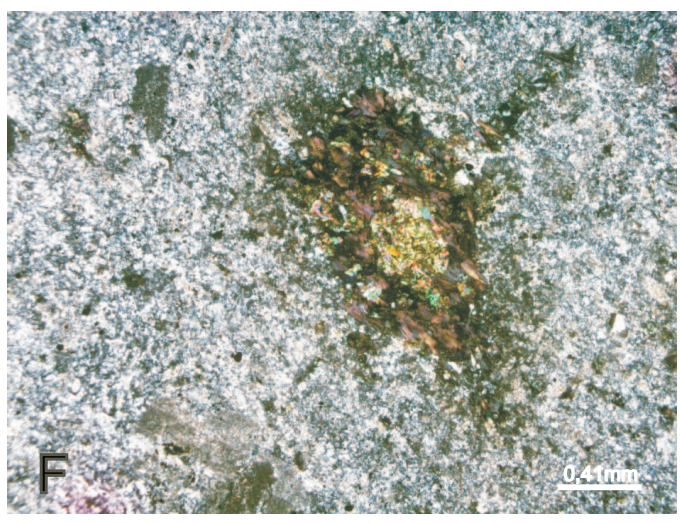

Fotomicrografia do latito, ilustrando a substituição completa de fenocristal de mineral máfico (anfibólio?, biotita ?) por cloritas, carbonatos, sericita e epidoto. Polarizadores cruzados. Amostra D-6. 
A alteração potássica é representada pela presença de venulações de feldspato potássico (Prancha 7, foto A, B), localmente associado com quartzo e epidoto. Parte do feldspato potássico presente na matriz pode ser também de origem hidrotermal. Os minerais opacos presentes são: pirita, calcopirita e magnetita. A pirita geralmente ocorre em grãos idiomórficos $(0,17 \mathrm{~mm})$.

\subsubsection{Micro-granodioritos porfiríticos}

Nas amostras mais típicas (S-3 e T-3) aparecem às alterações propílica e potássica combinadas, mas sempre muito fracamente desenvolvidas. Alteração fílica, associada à propílica, foi detectada nas amostras (J-1, -2, -3 e -4).

A alteração propílica é caracterizada pela substituição fraca de minerais máficos e fenocristais de plagioclásio por cloritas, epidoto e leucoxênio. Nos plagioclásios sericita também esta presente. Em alguns dos minerais máficos, particularmente (biotita), o epidoto desenvolve-se tipicamente nos planos de clivagem (Prancha 7, foto C e D).

A alteração potássica caracteriza-se pela presença de veios de feldspato potássico, que aparece por vezes intercrescido com quartzo (Prancha 7, foto E) e, em parte formando cristais na matriz da rocha. Neste último caso, a exemplo das situações similares descritas para outras rochas, a separação de feldspato potássico primário e de natureza hidrotermal é muito dificultada senão quase inviável. Considera-se que este tipo de alteração deva ter sido apenas incipiente nestas rochas.

A alteração fílica é representada por sericita, quartzo, minerais de argila e rutilo-leucoxênio Em algumas amostras esta alteração chega a ser muito pervasiva, obliterando quase que totalmente as características das rochas originais (e.g., amostras J-1 e J-2). Os minerais opacos típicos são: calcopirita, pirita magnetita e hematita. Nas amostras T-2 e T-3 foram identificadas molibdenita e bornita e bornita nas amostras T-3 e J-3.

\subsubsection{Micro-tonalitos}

Estas rochas, representadas pela amostra I-3, estão afetadas fracamente pelas alterações propílica e potássica combinadas. A alteração propílica é caracterizada pela substituição dos feldspatos por sericita e escassamente por carbonatos. Cloritas, com proporções menores de rutilo-leucoxênio, carbonatos, epidoto, sericita e calcopirita ocorrem em finos agregados, veios e pequenas fraturas.

A alteração potássica é caracterizada por veios e escassos agregados de feldspato potássico (Prancha 7, foto F). Os minerais opacos incluem pirita, calcopirita, molibdenita, rutilo-leucoxênio e galena. 


\section{PRANCHA 7}

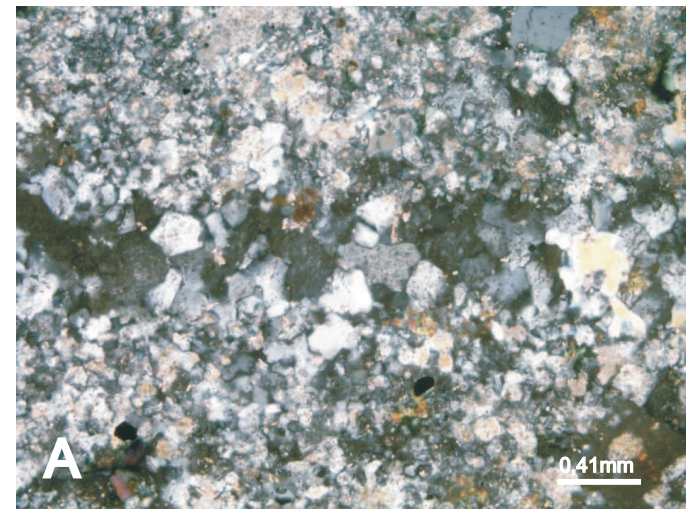

Fotomicrografia do latito, destacando venulação de feldspato potássico intercrescido com quartzo. Parte do feldspato potássico na matriz pode ser também de origem hidrotermal. Polarizadores cruzados. Amostra D-6.

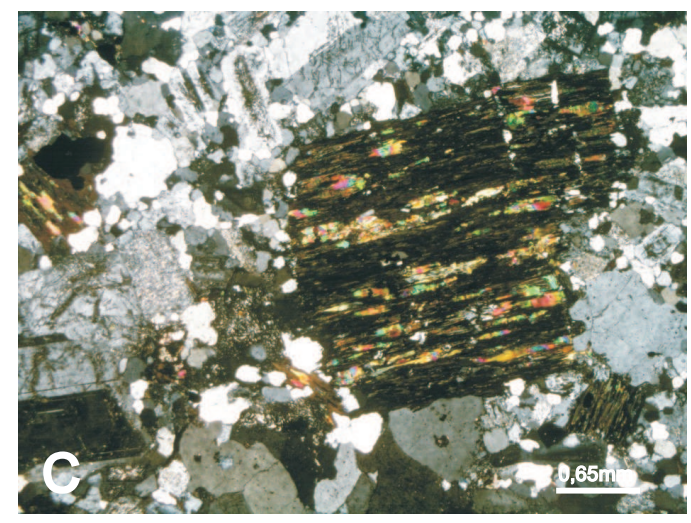

Fotomicrografia ilustrando a alteracão propílica em micro-granodiorito porfirítico. Fenocristal de biotita completamente substituído por clorita e epidoto, este último concentrado nos planos de clivagem da mica. Polarizadores cruzados. Amostra T-3.

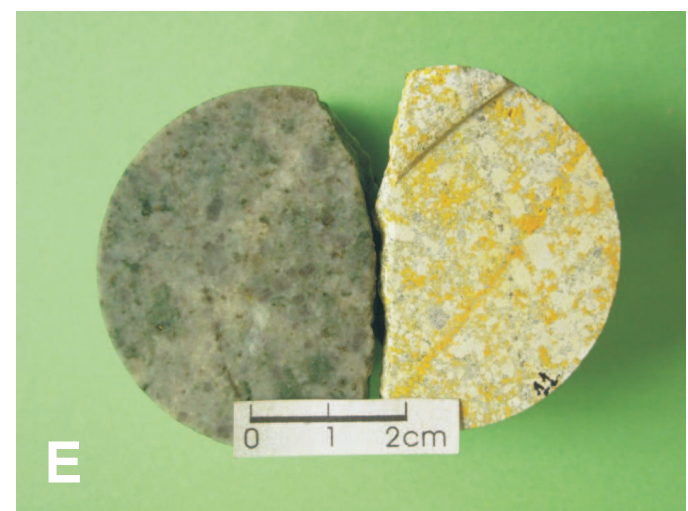

Micro-granodiorito porfirítico. À direita, fatia tingida, onde se observa veio constituído essencialmente de feldspato potássico, caracterizando a alteração potássica. Amostra T-2.

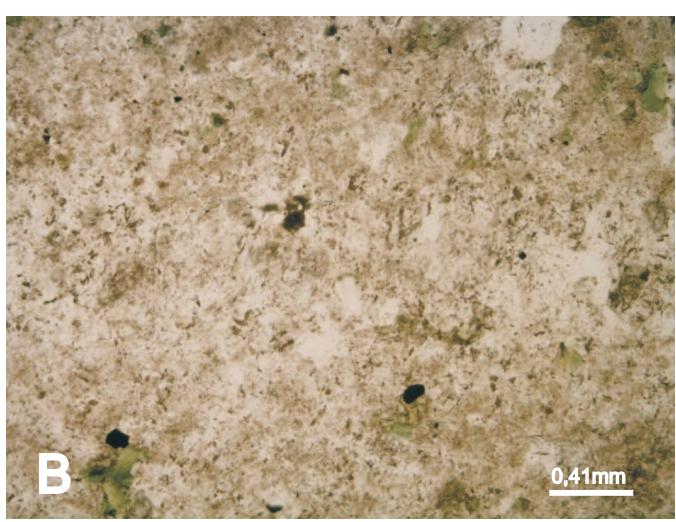

Idem A, sob luz plano polarizada, destacando o aspecto relativamente mais "sujo" do feldspato potássico no veio e na matriz, comparado com o quartzo.

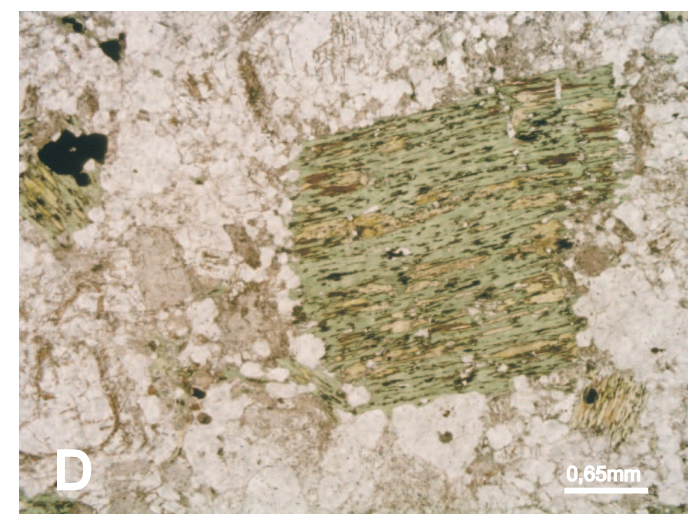

Idem C, sob luz plano polarizada.

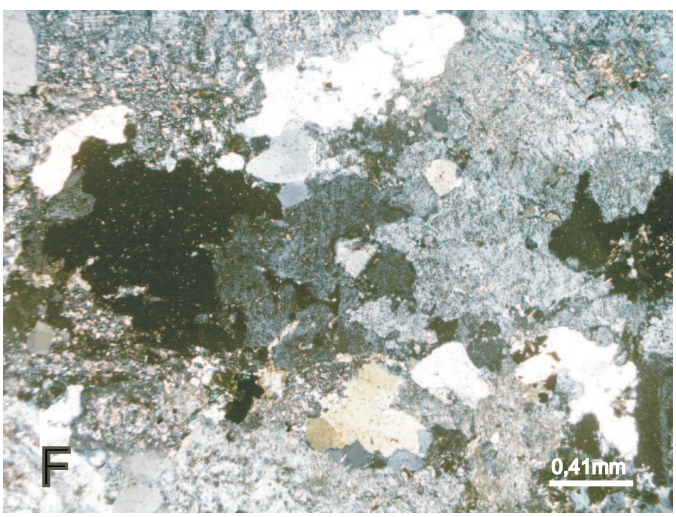

Fotomicrografia ilustrando venulações e agregados de feldspato potássico em micro-tonalito, caracterizando a alteração potássica. Polarizadores cruzados. Amostra R3. 


\subsubsection{Pórfiros I (micro quartzo monzonitos - micro monzogranitos)}

Estas rochas (amostras S-1, P-3, P-4, Q-2 e R-1) apresentam também alterações propílica e potássica fracas, combinadas.

A alteração potássica é caracterizada pelo feldspato potássico em veios associado ao quartzo, como nas amostras S-1, Q-2, e R-1 (Prancha 8, Foto A), mas, como no caso do microgranodiorito, porfirítico, latiandesito e latito, parte (escassa) do feldspato potássico presente na matriz poderia também representar produto de alteração hidrotermal.

A alteração propílica nesta rocha é caracterizada por cloritas, carbonatos e sericita. A sericita, os carbonatos e às vezes cloritas estão substituindo fracamente plagioclásio (Prancha 8, foto B). Tanto as cloritas como a sericita ocorrem em finos veios por vezes associadas a leucoxênio. Algumas vezes os carbonatos alteram parte da matriz da rocha (amostras P-3 e P-4).

Os minerais opacos mais freqüentes são: pirita, calcopirita e rutilo-leucoxênio. Molibdenita e magnetita são menos freqüentes.

\subsubsection{Pórfiros II (micro tonalitos - micro leucoquartzo dioritos)}

Estas rochas apresentam alterações do tipo potássica, propílica, fílica e silicificação, todas elas combinadas e com graus de intensidade variáveis, entre incipientes a fracas.

A alteração potássica é caracterizada pela presença de veios de feldspato potássico intercrescidos, com quantidades menores, de quartzo (Prancha 8, foto $\mathrm{C}$ ), como observado nas amostras D-4, O-3, Q-3, P-2 e U-3.

A alteração propílica ocorre incipientemente em todas as amostras estudadas. Está caracterizada pela presença essencial de cloritas, carbonatos, epidoto, argilas e subordinadamente quartzo e sericita. Geralmente os minerais máficos são os mais afetados por este tipo de alteração (Prancha 8, foto D, E), mas alguns feldspatos também estão sendo substituídos debilmente (Prancha 8, foto F). Veios finos de quartzo, carbonatos e cloritas também estão presentes. Nas amostras O-2 e D-1, a carbonatização é típica.

A alteração fílica é fraca e está caracterizada pela presença de sericita e quartzo (amostras O-2, U-2 e U-3). A sericita ocorre na matriz intercrescida com quartzo, mas também substitui o plagioclásio (Prancha 9, foto A).

A silicificação, como no caso dos andesitos, foi caracterizada pela abundância de quartzo, particularmente na forma de veios e agregados irregulares que em parte se confundem com o quartzo primário presente na matriz da rocha (amostras D-4, O-3, P-2, Q-3 e U-3). Esta alteração é mais típica das amostras H-4 e U-2. Como nos demais casos, não foi possível estabelecer com segurança critérios que permitissem separar convenientemente quartzo hidrotermal e primário. 
Entre os minerais opacos tem-se: pirita, calcopirita, molibdenita, rutilo-leucoxênio. Magnetita, hematita, bornita são mais escassos.

\subsubsection{Micro-brecha}

Estas rochas apresentam alteração propílica de tipo carbonatização, onde grande parte da matriz e dos fragmentos de fenocristais foi substituída por carbonatos e sericita (Prancha 9, foto B). Ocorrem também fragmentos de fenocristais completamente substituídos por cloritas, sericita-quartzo e sericita. Pirita e calcopirita ocorrem disseminadas.

\subsubsection{Pórfiros alterados}

Sob esta designação foram classificadas rochas cujas texturas ainda sejam preservadas a mineralogia primária foi completamente substituída pela alteração. Estas rochas possivelmente pertencem ao grupo dos riolitos ou pórfiros II (microtonalitos - micro leuco quartzo dioritos). Apresentam alterações fílica, propílica e silicificação combinadas.

A alteração fílica é moderada a forte (amostras O-1, K-1, P-1, U-1, e.g., Prancha 9, foto C) e está caracterizada pela presença de sericita e quartzo, os quais ocorrem intercrescidos na matriz. A sericita também ocorre formando finos agregados e preenchendo pseudomorfos de fenocristais de feldspatos, às vezes acompanhadas de rutilo-leucoxênio. O quartzo também ocorre em veios.

A alteração propílica é incipiente (amostras P-1), fraca (amostras U1 e S-2) e moderada (amostra T-1), estando representada por cloritas, carbonatos, epidoto, minerais de argila e sericita.

A silicificação está caracterizada presença, relativamente abundante, de quartzo na forma de pequenos veios e agregados, nas amostras S-2 e T1.

Os minerais opacos identificados são: pirita, calcopirita, rutilo-leucoxênio e molibdenita. Magnetita, hematita, bornita e covelita foram observadas esporadicamente. 


\section{PRANCHA 8}

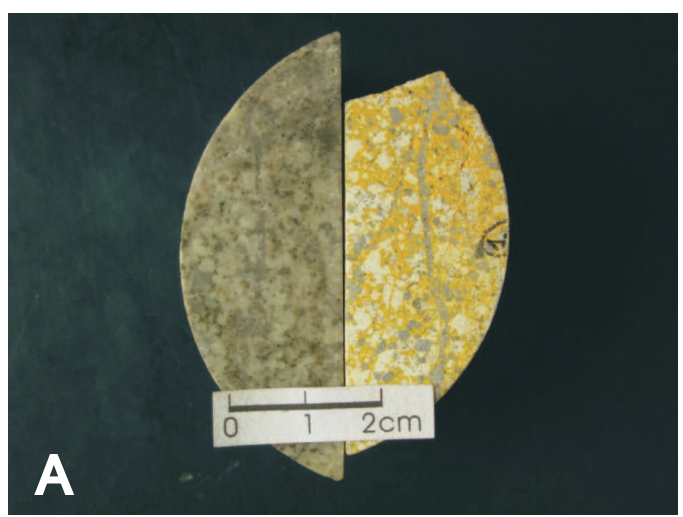

Pórfiro-I original e tingido, para destacar finas venulações de feldspato potássico que caracterizam a alteração potássica. Parte do feldspato potássico da matriz também deve ser de origem hidrotermal. Veio de quartzo atravessa a amostra. Amostra R-1.

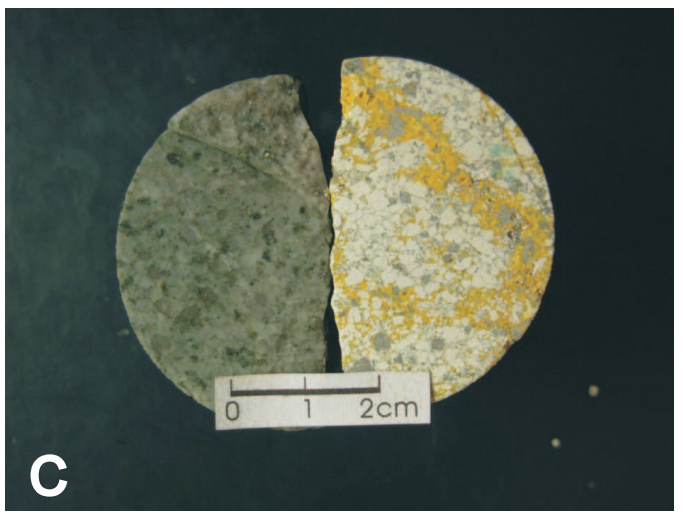

Imagens do pórfiro-II, ilustrando venulações de espessuras variáveis, ricas em feldspato potássico, caracterizando a alteração potássica. Amostra Q-3 .

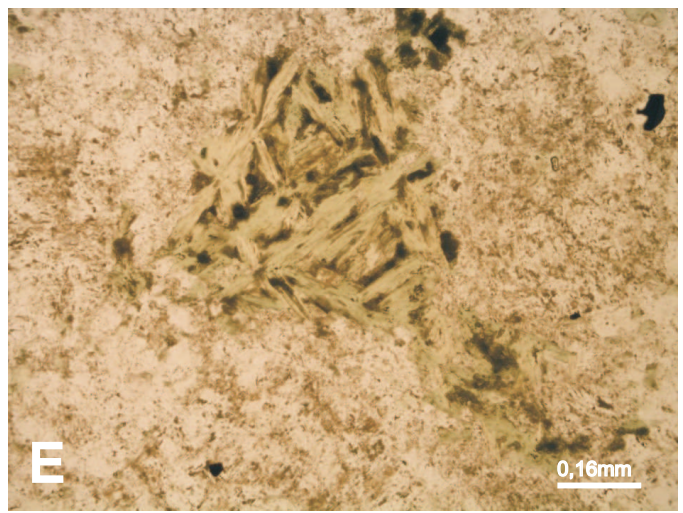

Idem $\mathrm{D}$, sob luz plano polarizada.

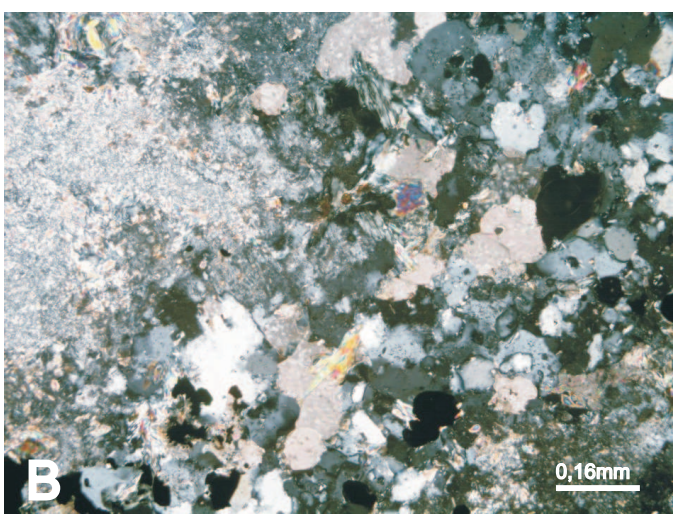

Fotomicrografia do pórfiro-I, destacando alteração propílica. À esquerda, fenocristal de plagioclásio alterado para sericita e carbonatos imerso em matriz parcialmente substituída por clorita, carbonatos e minerais opacos. Polarizadores cruzados. Amostra R-1.

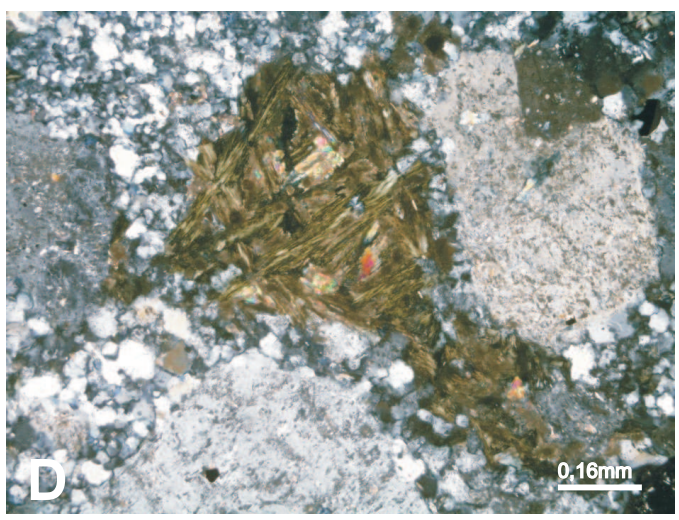

Fotomicrografia do pórfiro-II, destacando relicto de fenocristal de mineral máfico (anfibólio?) totalmente substituído por clorita, epidoto e minerais opacos. Ao lado, fenocristal de plagioclásio, quase que totalmente substituído por argilas. Parte da matriz também esta substituída debilmente por argilas. Polarizadores cruzados. Amostra U-3.

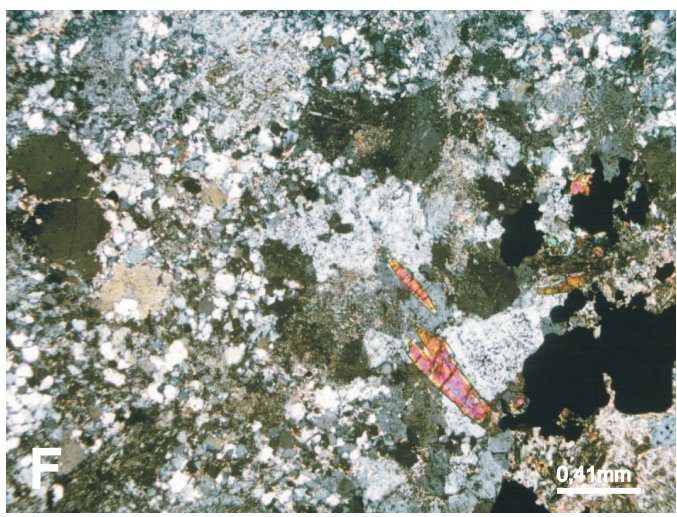

Fotomicrografia destacando grãos subhedrais de epidoto (colorido) substituíndo e cortando plagioclásio. Amostra U-3. 


\subsubsection{Hidrotermalitos}

Inclue-se sob esta designação as rochas cujas texturas e mineralogia primárias foram completamente obliteradas pela alteração (intensidade pervasiva a muito pervasiva). A rocha original pode apenas ser inferida com base na localização das amostras estudadas nos furos de sondagem.

As alterações presentes são: propílica, fílica e potássica. A alteração propílica afeta mais caracteristicamente os andesitos, enquanto a alteração fílica (Prancha 9, foto D) é predominante nos riolitos e microgranodioritos porfiríticos. No caso de alteração potássica pervasiva (Prancha 9, foto E) não foi possível inferir a rocha original.

Os minerais opacos presentes nos hidrotermalitos propilíticos são pirita, calcopirita, magnetita e, menos freqüentemente, molibdenita. No caso dos hidrotermalitos fílicos, além de pirita e calcopirita, tem-se rutilo-leucoxênio, covelita, calcocita, molibdenita e bornita mais escassos. Os hidrotermalitos potássicos apresentam mineralogia opaca similar a este último grupo. 


\section{PRANCHA 9}

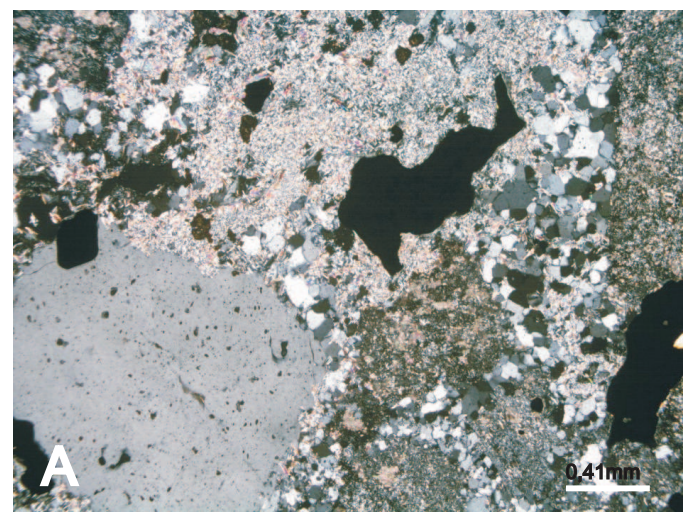

Fotomicrografia do pórfiro-II destacando alteração fílica caracterizada pela sericita e quartzo que substitui à matriz e parcialmente aos fenocristais de feldspatos (direita). Minerais opacos ocorrem disseminados, alguns deles hipidiomórficos. Polarizadores cruzados. Amostra U-2.

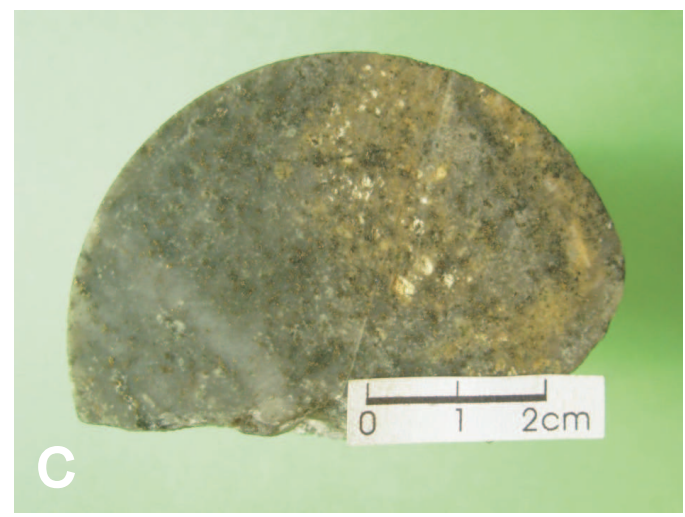

Imagem do pórfiro alterado com forte alteração fílica caracterizada pela sericita com predomínio no lado direito da amostra (amarelo) e quartzo no lado esquerdo. A alteração propílica é insipiente e está caracterizada por cloritas (zonas verdes) e carbonatos (zonas brancas). Amostra U-1.

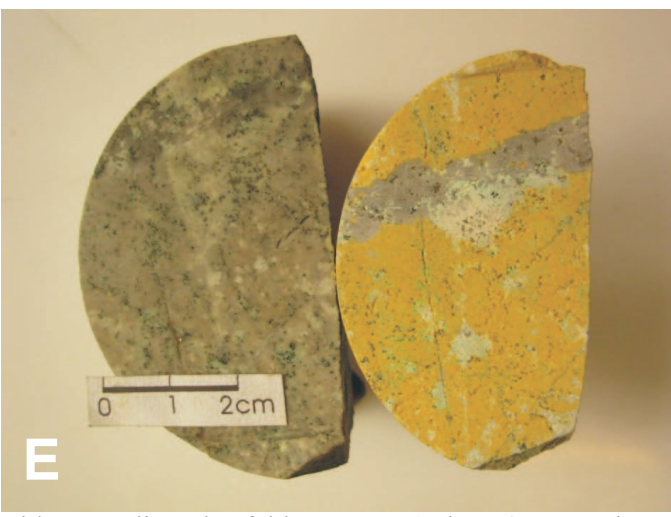

Hidrotermalito de feldspato potássico (zonas cinza rosáceas), sericita (zonas brancas), quartzo (cinza) e escasso rutilo caracterizando a alteração potássica. À direita, fatia tingida ressalta o predomínio de feldspato potássico e o veio de quartzo que atravessa a amostra. As zonas brancas correspondem a sericita. Amostra U-1 .

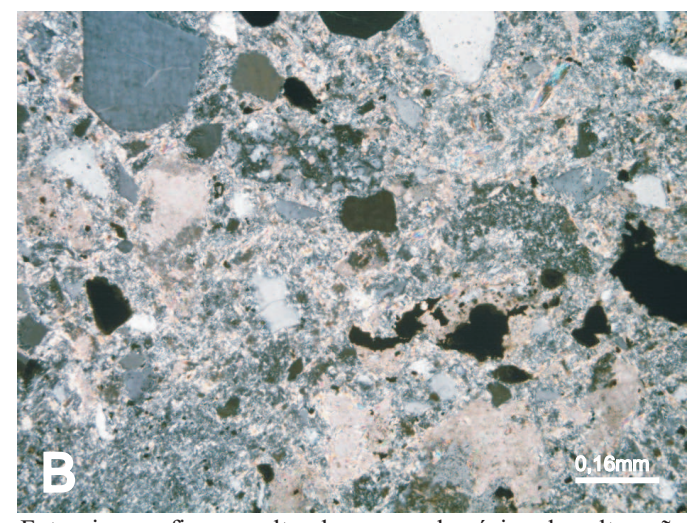

Fotomicrografia ressaltando o predomínio da alteração propílica do tipo carbonatização na microbrecha. Grande parte da matriz e de alguns fenocristais estão completamente substituídos por carbonatos. Observam-se também, alguns fenocristais substituídos por quartzo (centro superior). Minerais opacos ocorrem disseminados. Polarizadores cruzados. Amostra H-4.

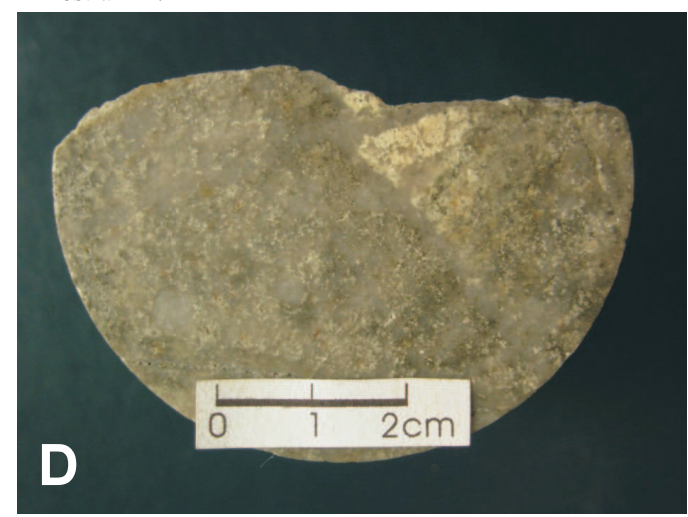

Hidrotermalito de quartzo-sericita caracterizando a alteração fílica. Notar que a textura da amostra original foi completamente substituída pela sericita (branco amarelento) e quartzo (branco cinzento). Venulações de quartzo atravessam a amostra. No lado superior direito da amostra se observa uma zona com forma tabular de cor branca composta por carbonatos. Amostra Q-1. 



\section{7 \\ Caracterização e distribuição das inclusões e intercrescimentos}

Neste capítulo apresentam-se os resultados dos estudos das inclusões e dos intercrescimentos entre as fases sulfetadas na jazida de Cuajone que envolvem caracterização microscópica, química e análise estatística da sua distribuição nas diferentes zonas de alteração hidrotermal.

\subsection{Inclusões e intercrescimentos: Ocorrência e importância}

\subsubsection{Introdução}

De acordo com Hagel (1994), inclusões correspondem a ocorrências de fases minerais dentro de outras fases, usualmente identificadas ao microscópio óptico. Os intercrescimentos, por sua vez, são definidos pelas texturas e/ou micro-estruturas resultantes da associação das fases incluídas com a fase hospedeira.

Segundo este autor, os principais mecanismos que originam inclusões são: captura acidental de cristais de fases minerais formadas simultaneamente com a fase hospedeira por esta última; relictos de uma fase mineral pré-existente que foi substituída pela fase hospedeira; desdobramento de mecanismos de exsolução a partir de uma solução sólida inicial e cocristalização de fases minerais independentes. O termo intercrescimento é utilizado de forma descritiva, independentemente dos mecanismos que o geraram ou ainda da identificação das fases hospedeiras ou hospedadas.

Minerais de minério sulfetados formam soluções sólidas freqüentemente que, sob certas condições de resfriamento, desmisturam-se originando texturas e/ou micro-estruturas de ex- 
solução. Estas texturas podem ser reconhecidas ao microscópio e permitem obter informações sobre as temperaturas de formação e sobre a gênese dos minerais. Em geral, o número de combinações minerais possíveis em um determinado intercrescimento é limitado, auxiliando a sua identificação. Isto é especialmente importante nos intercrescimentos originados por exsolução, já que o número possível de combinações está restrito as possibilidades de existência de soluções sólidas. As maiores dificuldades aparecem quando se faz necessário distinguir intercrescimentos deste tipo, daqueles produzidos por substituição ou deposição simultânea. Diversos critérios têm sido definidos e utilizados para diferenciá-los ( $c f$. Bastin et al., 1931; Edwards, 1954; Ramdohr, 1980; Demidov \& Muñoz, 1993; Hagel, 1994; Craig \& Vaughan, 1994), que auxiliam significativamente esta tarefa.

Com base nestes conceitos, será utilizado o termo "inclusão sólida" de forma descritiva para identificar inclusões de uma ou mais fases minerais, formando diferentes tipos de intercrescimentos com a fase hospedeira.

\subsubsection{Importância das Inclusões e intercrescimentos nos Pórfiros Peruanos}

A importância do estudo de inclusões sólidas nas jazidas de $\mathrm{Cu}$ de tipo pórfiro no Perú emergiu a partir do trabalho inédito de Canchaya (1993) em que o autor apresenta os resultados do estudo sobre a assembléia sulfetada pirita + calcopirita \pm pirrotita \pm cubanita \pm mackinawita baseado na análise microscópica de cerca de 400 amostras de diferentes jazidas. Este autor percebeu que a calcopirita ocorre de forma freqüente como diminutas inclusões em pirita, muitas vezes associadas com pirrotita e/ou cubanita e/ou mackinawita, com as quais forma intercrescimentos típicos.

Na Tabela 7.1 estão reproduzidos os resultados obtidos pelo autor, enfatizando o número total de amostras estudadas para cada jazida examinada e o número de amostras em que a referida assembléia aparece, considerando-se que a assembléia está caracterizada quando, além de pirita e calcopirita, pelo menos um dos demais minerais (pirrotita, cubanita e mackinawita) está presente. O autor ressalta que os mencionados sulfetos estão presentes em 50\% das amostras analisadas e que a assembléia pirita + calcopirita \pm pirrotita \pm cubanita \pm mackinawita é típica nas jazidas do tipo pórfiro no Perú. Sugere também que a ocorrência e distribuição destes minerais poderiam estar relacionadas ao tipo de alteração, uma vez que observou maior freqüência de intercrescimentos entre pirita e pirrotita na zona potássica, entre calcopirita e cubanita na zona fílica e intercrescimentos com mackinawita presente na zona propílica.

Estes resultados preliminares indicam que o estudo das assembléias de sulfetos podem-se converter em critérios úteis para definir prospectos, sobretudo para a alocação de sondagens durante a etapa de exploração das jazidas. Por outro lado, o estudo destes intercrescimentos também é fundamental para a compreensão dos mecanismos genéticos de formação dos sulfetos e geotermometria. 
Tabela 7.1: Ocorrência da assembléia py-cp-po-cb-mck nos principais pórfiros de cobre peruanos, de acordo com Canchaya (1993).

\begin{tabular}{|c|c|c|c|c|}
\hline \multirow{2}{*}{ Jazida } & \multirow{2}{*}{$\begin{array}{c}\text { Amostras } \\
\text { Estudadas }\end{array}$} & \multicolumn{2}{|c|}{$\begin{array}{c}\text { Amostras que apresentaram } \\
\text { a assembléia (o) }\end{array}$} & \multirow{2}{*}{ Observações } \\
\hline & & Quantidade & $\%$ & \\
\hline Quellaveco & 192 & 132 & 68.7 & $\begin{array}{l}\text { A fase mais frequente é a } \\
\text { mackinawita; a mais } \\
\text { abundante a cubanita. }\end{array}$ \\
\hline Cerro Verde & 86 & 31 & 36.0 & $\begin{array}{c}\text { A assembléia raras vezes } \\
\text { ocorre a profundidades } \\
\text { menores de } 150 \mathrm{~m} .\end{array}$ \\
\hline Toromocho & 12 & 10 & 83.3 & $\begin{array}{l}\text { Nas amostras estudadas não } \\
\text { se encontrou magnetita. }\end{array}$ \\
\hline Toquepala & 15 & 9 & 60.0 & $\begin{array}{l}\text { As três ultimas amostras } \\
\text { são de concentrados. }\end{array}$ \\
\hline Michiquillay & 31 & 8 & 25.8 & $\begin{array}{l}\text { Não foi reportado } \\
\text { mackinawita nem cubanita; } \\
\text { só pirrotita. }\end{array}$ \\
\hline Cuajone & 14 & 2 & 14.3 & $\begin{array}{l}\text { O mesmo que na jazida de } \\
\text { Quellaveco e Toquepala, } \\
\text { nas amostras onde ocorre a } \\
\text { assembléia, a magnetita não } \\
\text { esta presente. }\end{array}$ \\
\hline La Huaca & 18 & - & - & \multirow{2}{*}{$\begin{array}{c}\text { Só foi reportado pirita e } \\
\text { calcopirita, não se observou } \\
\text { mackinawita, cubanita nem } \\
\text { pirrotita. }\end{array}$} \\
\hline Coroccohuayco & 21 & _ & - & \\
\hline Total & 389 & 192 & 49.0 & \\
\hline
\end{tabular}

(o) A assembléia só considera-se presente sim além da pirita e calcopirita ocorre pelos menos um dos outros três minerais.

\subsubsection{Inclusões Sólidas no Pórfiro de Cuajone}

No presente trabalho foram estudadas 77 amostras de testemunhos de sondagem para examinar as assembléias sulfetadas presentes como inclusões sólidas na jazida de Cuajone, para confirmar e detalhar os resultados preliminares de Canchaya (1993), baseados em apenas 14 amostras, das quais em apenas duas foram encontradas inclusões envolvendo estes sulfetos.

Os trabalhos preliminares ao microscópio confirmaram a presença de minúsculas inclusões sólidas, particularmente de calcopirita e, subordinadamente, de pirrotita em parte significativa dos cristais de pirita na maioria das amostras. Observou-se que a calcopirita na maioria das vezes ocorre formando intercrescimentos típicos com pirrotita e/ou cubanita e/ou mackinawita, aparecendo associada com um, dois ou mesmo três destes minerais. Inclusões homogêneas de calcopirita também foram observadas, mas não foram detalhadas, já que o foco principal da pesquisa está nas associações entre estes sulfetos. 
O reconhecimento óptico das diferentes fases sulfetadas mostrou-se viável após uma primeira fase de familiarização. Assim a pirita apresenta cor branca amarela, é isotrópica e não apresenta birreflectância; adicionalmente apresenta maior relevo quando comparada com os minerais mencionados. A calcopirita tem cor amarela brilhante a levemente esverdeada, birreflectância muito fraca e anisotropia moderada com tons entre cinzento azulado a amarelo esverdeado. A pirrotita possui cor creme com tinta fortemente rosa a marrom, birreflectância moderada a forte, é fortemente anisotrópica com tons entre amarelo esverdeado, azulado e/ou marrom avermelhado. A cubanita apresenta cor amarela fraca a marrom, birreflectância fraca e anisotropia moderada com tons entre marrom rosa a cinzento azulado. A mackinawita tem cor entre cinza e creme ou marrom claro, birreflectância e anisotropia muito fortes, esta última entre branco cinza a cinza escuro ou negro.

\section{Morfologia dos Minerais Associados às Inclusões}

A escala de observação no microscópio óptico (aumento 20x) as inclusões solidas observadas em pirita geralmente apresentam formas arredondadas a ovaladas (Prancha 10, foto A e F), com diâmetros variáveis em media entre X0.0 a 0.X $\mu \mathrm{m}$. Utilizando maiores aumentos (50x e 100x) algumas vezes é possível reconhecer ora formas bem irregulares (Prancha 10, foto B), ora formas bem definidas (Prancha 10, foto C, D e E).

A pirrotita apresenta formas em geral arredondadas quando ocorre como inclusões isoladas na pirita. Quase com a mesma frequência apresenta formas irregulares com contornos arredondados (Prancha 10, foto B e E) quando intercrescida com a calcopirita. Neste caso as formas arredondadas são menos comuns, mas também são observadas (prancha 11, foto A).

A cubanita sempre apresenta formas lamelares, (Prancha 10, foto F e Prancha 11, foto A). A mackinawita freqüentemente apresenta forma irregular a vermiforme (Prancha 11, foto B e C) seguida de forma amebóide (Prancha 11, foto D).

\section{Caracterização e Classificação dos Intercrescimentos Típicos}

Canchaya \& Cardoso (1984) apresentaram uma compilação da classificação morfológica dos intercrescimentos mais típicos encontrados, abordados de uma forma puramente descritiva, com base nos trabalhos pioneiros de Ramdohr (1980), Smirnov (1982), Amstutz (1971). Estes autores reconhecem 16 tipos principais de intercrescimentos, ilustrados na Figura 4.2: simples (1a), amebóide (1b), gráfico (1c), disseminado (1d), inclusão (1e), coroa (2a), sub-coroa (2b), concêntrico (2c), coloforme (2d), sanduiche (3a), estratificado (3b), reticular (3c), em veios (3d), borda composta (4a), compenetração (4b) e intersticial (4c).

Mais recentemente, Hagel (1994) apresenta uma classificação simplificada, considerando 9 tipos de intercrescimentos, denominados respectivamente: simples (1a), amebóide (1b), gráfico (1c), disseminado (1d), coroa (2a), concêntrico (2c), sanduiche (3a), estratificado (3b) e reticular (3c). 
Nesta dissertação, utilizar-se-á a classificação dos primeiros autores, por ser algo mais completa. Adicionalmente, foi incorporado mais um tipo de intercrescimento, denominado 4f, que é uma variação dos tipos 1d e 1c. Os intercrescimentos mais típicos e representativos observados no estudo microscópico foram classificados em dois grupos: simples (constituídos por até dois minerais) e complexos (formados por mais de dois minerais), como detalhado a seguir:

Simples: (e.g., Prancha 10, fotos A e B).

cp/mck: 1b, 1e, 3b, 3c, 4f

$\mathrm{cp} / \mathrm{cb}: 1 \mathrm{a}, 3 \mathrm{a}$

$\mathrm{cp} / \mathrm{po}: 1 \mathrm{a}, 1 \mathrm{~b}, 1 \mathrm{e}, 3 \mathrm{a}, 4 \mathrm{f}$

po/cp: $1 \mathrm{a}, 1 \mathrm{~b}$

Complexos: (e.g.,. Prancha 10, foto F).

(cp/po: 1b)/mck:1b

(cp/cb: 3a)/po:1e

(cp/po: 1b)/mck:1e

(cp/po: 1b)/cb:3a

Todos estes intercrescimentos ocorrem sob a forma de inclusões em pirita. Deve ser destacado que o intercrescimento de tipo simples py/po:1e é o único formado diretamente em pirita (Prancha 10, foto D). Outros intercrescimentos, embora eventualmente presentes, não serão considerados na discussão por serem bem menos abundantes, mas são apresentados nas Tabelas (1-8) no Anexo 7. 


\section{PRANCHA 10}

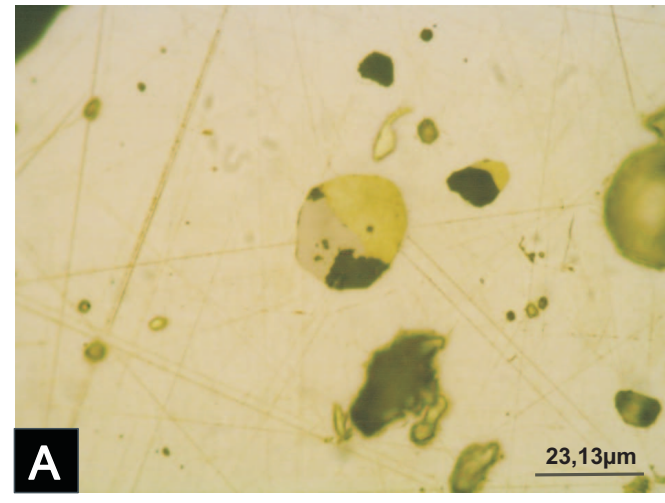

Fotomicrografia ressaltando inclusão subarredondada de calcopirita (amarelo forte) intercrescida com pirrotita (rosa) em grão de pirita (amarelo fraco). O tipo de intercrescimento formado entre a pirrotita e calcopirita é: la (simples). Luz refletida, plano polarizada. Amostra M-4.

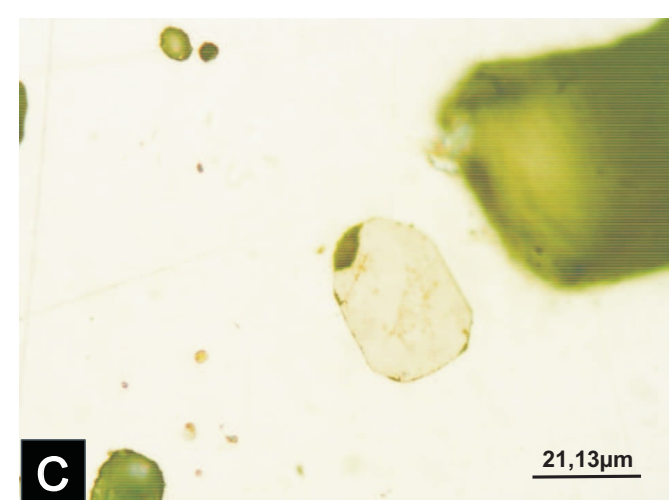

Fotomicrografia destacando inclusão de pirrotita (rosa) de forma bem definida (euhedral) em grão de pirita (amarelo fraco). Neste caso a pirrotita ocorre diretamente intercrescida com a pirita formando intercrescimento tipo: 1e. Luz refletida, plano polarizada. Amostra F-2.

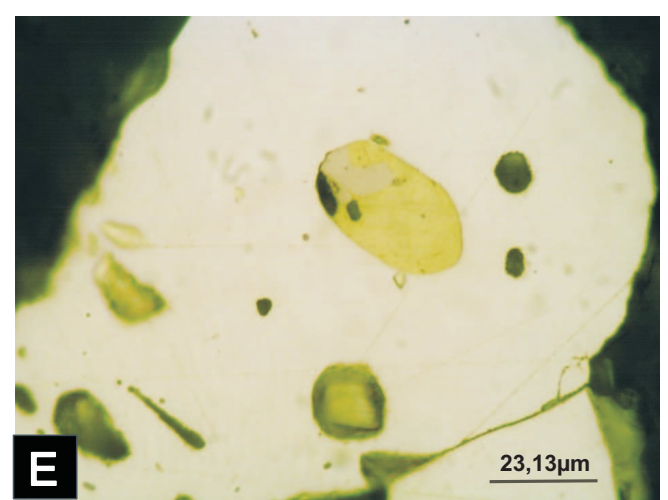

Fotomicrografia ilustrando inclusão subhedral de calcopirita (amarelo forte) intercrescida com pirrotita (rosa) em grão de pirita (amarelo fraco). Notar que a pirrotita apresenta borda amebóide com contornos arredondados, formando com a calcopirita intercrescimento do tipo: 1b. Luz refletida, plano polarizada. Amostra M-3.

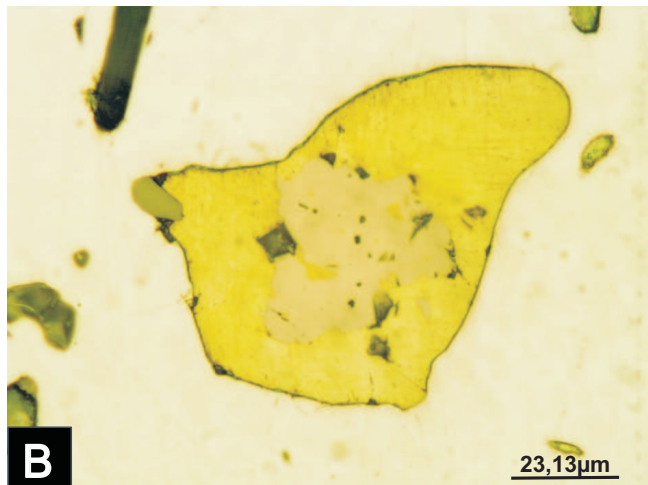

Fotomicrografia destacando inclusão de calcopirita (amarelo forte) com forma irregular e contornos arredondados em pirita (amarelo fraco). Por sua vez a pirrotita (rosa) aparece incluída em calcopirita formando intercrescimento tipo: 1e (inclusão). Notar que a pirrotita também tem contorno irregular. Luz refletida, plano polarizada. Amostra F-2.

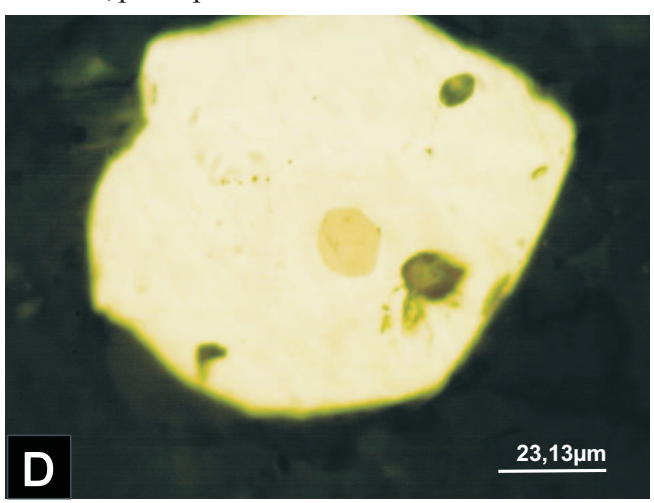

Fotomicrografia ressaltando inclusão de pirrotita (rosa) com forma bem definida (euhedral) em grão de pirita subhedral (amarelo fraco). Estes dois minerais estão formando intercrescimento do tipo inclusão: 1e como em C. Luz refletida, plano polarizada. Amostra D-5.

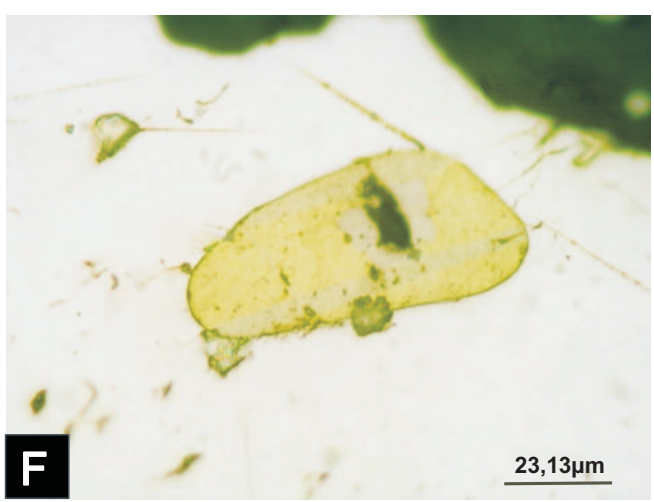

Ilustração destacando inclusão oval de calcopirita (amarelo forte) em pirita (branco amarelento). A calcopirita ocorre intercrescida com pirrotita (rosa) de forma irregular e cubanita (rosa amarelo) em lamelas. Estes minerais formam intercrescimento complexo do tipo: (cp/cb:3a)/po:1e. Luz refletida, plano polarizada. Amostra J-4. 


\section{PRANCHA 11}

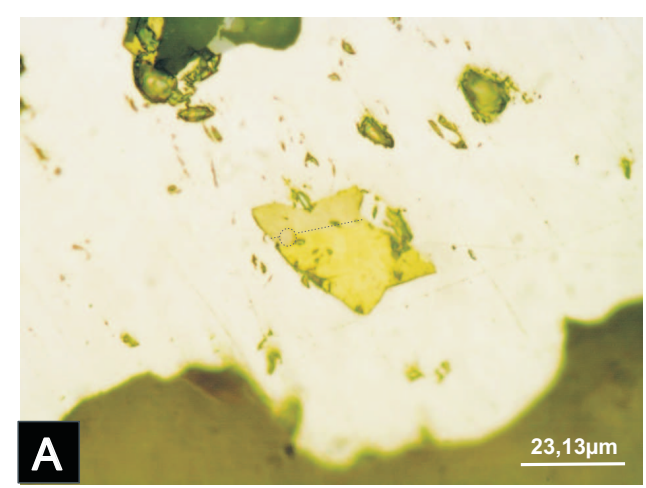

Fotomicrografia ilustrando inclusão amorfa de calcopirita (amarelo forte) com bordas definidas em pirita (amarelo fraco). A calcopirita forma intercrescimento complexo com a pirrotita (rosa) e cubanita (rosa amarelo) do tipo: (cp/cb:1a)/po:1e. Notar que a pirrotita apresenta forma arredondada e a cubanita tem forma lamelar. Luz refletida, plano polarizada. Amostra F-2.

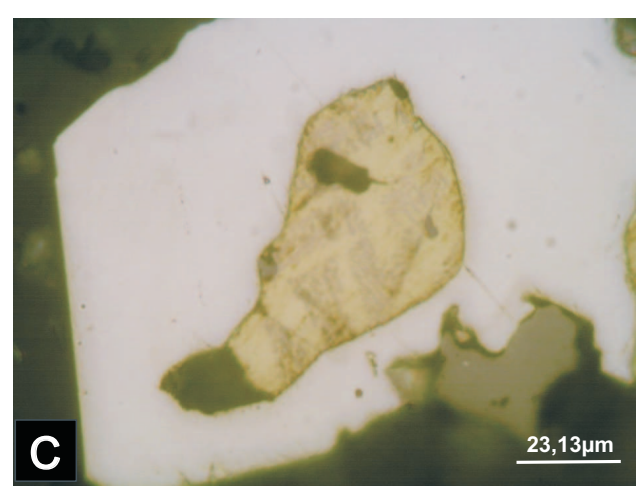

Fotomicrografia ilustrando inclusão sub-oval de calcopirita (amarelo forte) intercrescida com mackinawita (rosa violáceo) em grão de pirita (branco amarelento). O tipo de intercrescimento simples entre a calcopirita e mackinawita é $\mathrm{cp} / \mathrm{mck}: 3 \mathrm{c}$. Notar a forma irregular a vermiforme da mackinawita apesar de formar outro tipo de intercrescimento comparado com C. Luz refletida, plano polarizada. Amostra M-2.

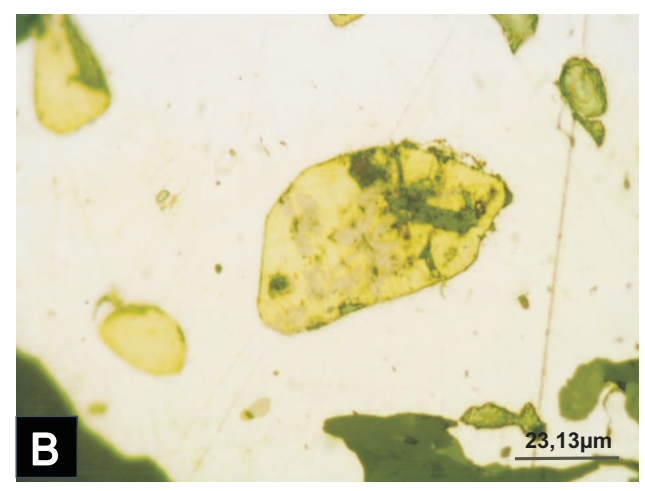

Fotomicrografia ressaltando inclusão sub-oval de calcopirita (amarelo forte) intercrescida com mackinawita (rosa violácea) num grão de pirita (amarelo fraco). Notar a forma irregular a vermiforme da mackinawita. A calcopirita e mackinawita formam intercrescimento simples do tipo: cp/mck:4f. Luz refletida, plano polarizada. Amostra M-5.

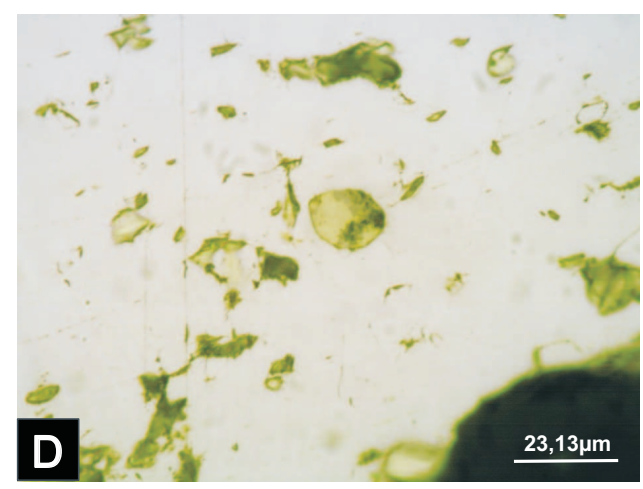

Fotomicrografia destacando, na parte central, inclusão sub-arredondada de calcopirita (amarelo forte) com mackinawita (rosa violácea) num grão de pirita (amarelo fraco). Neste caso a mackinawita esta formando com a calcopirita intercrescimento simples do tipo: $\mathrm{cp} / \mathrm{mck}: 1 \mathrm{~b}$. com contornos arredondados (amebóide). Luz refletida, plano polarizada. Amostra F-1. 


\subsection{Caracterização química dos intercrescimentos e inclusões}

\subsubsection{Mapas composicionais}

Mapas composicionais foram obtidos para caracterizar a distribuição dos elementos químicos mais importantes nas diferentes fases sulfetadas (pirita, calcopirita, pirrotita, cubanita e mackinawita) que formam os diferentes tipos de intercrescimentos, auxiliar no estudo morfológico dos intercrescimentos, substanciar os resultados obtidos no microscópio petrográfico e também para permitir a localização mais precisa para as análises quantitativas pontuais. Assim, foram obtidos mapas representativos para as amostras D-5, Q-3, F-2, F-1 e M-5, as três primeiras que correspondem às zonas de alteração potássica-propílica e as duas últimas a zonas potássicapropílica/fílica e propílica-potássica, respectivamente. Os elementos $\mathrm{S}, \mathrm{Fe}, \mathrm{Cu}, \mathrm{Ni}$ e $\mathrm{Si}$ foram analisados em WDS e Co, Zn e Au em EDS (cf. Capítulo 4, materiais e métodos), mas somente foram reproduzidas imagens para os elementos que ocorrem de forma significativa. As imagens obtidas (imagem ao microscópio sob luz refletida, imagem de elétrons retro-espalhados (BSE) e imagem de raios-X para os elementos mais típicos) são apresentadas nas pranchas 12 a 17 . Nas imagens BSE são adicionalmente representados os pontos em que foram obtidas análises quantitativas pontuais, apresentadas no item seguinte. Os mapas obtidos são descritos caso a caso a seguir.

\section{Amostra D-5}

Na prancha 12 apresentam-se as imagens obtidas para uma inclusão de tipo complexa (cp/mck:1b,4f)/po:1e, em que aparecem associadas em intercrescimento calcopirita, mackinawita e pirrotita, típica da zona de alteração potássica-propílica. Os mapas composicionais para S, Cu e Fe ilustram bem a distribuição destas fases minerais nos intercrescimentos e dão suporte para as descrições morfológicas dos intercrescimentos conforme detalhadas ao microscópio. O mapa de $\mathrm{S}$ separa muito bem pirita $\left(\mathrm{FeS}_{2}\right)$ de calcopirita $\left(\mathrm{CuFeS}_{2}\right)$, pirrotita $\left(\mathrm{Fe}_{1-x} \mathrm{~S}\right)$ e mackinawita $\left(\mathrm{Fe}_{1+x} \mathrm{~S}\right)$, mas não separam adequadamente estes dois últimos minerais. $\mathrm{O} \mathrm{Cu}$ ilustra claramente onde está calcopirita, mas não separa pirrotita de mackinawita, no entanto o Fe separa bem estes dois minerais de calcopirita e pirita. É interessante observar que a distribuição do Co mostra que este elemento aparece em concentrações mais elevadas na mackinawita e em quantidades não significativas na calcopirita. As tonalidades intermediárias obtidas para a fase hospedeira, pirita, sugerem que esta também contenha algum Co. No caso do Zn, a respectiva imagem sugere que este elemento está presente apenas na calcopirita, particularmente na zona inferior da inclusão, onde este mineral apresenta-se intercrescido de forma mais íntima com a mackinawita. Zonas com elevadas concentrações em Si indicam fases silicáticas associadas.

\section{Amostra F-1}

A Prancha 13 corresponde a um exemplo de uma inclusão com intercrescimento complexo: (cp/po:1b)/cb:3a, que envolve calcopirita com pirrotita, cubanita e possível macki- 
nawita, sendo assim, o intercrescimento sería:[(cp/po:1b)/cb:3a]/mck(?):1e, representativa da zona de alteração potássica-propílica/fílica. A calcopirita é destacada pelo mapa do $\mathrm{Cu}$, a pirrotita pelo mapa de $\mathrm{Fe}$ (alto $\mathrm{Fe}$, baixo $\mathrm{Cu}$ ) e a cubanita tanto pelos mapas do $\mathrm{Cu}$ e $\mathrm{Fe}$, já que tem proporções menores de cobre quando comparada com a calcopirita e menores de Fe quando comparada com a pirrotita, a mackinawita é mais difícil de ser separada porque tem proporções similares de Fe e $\mathrm{S}$ que a pirrotita. O mapa do Ni mostra diminutas áreas (não distinguidas opticamente) com a concentração deste elemento, as quais podem indicar a presença de mackinawita ou podem ser áreas de pirrotita com concentração de Ni.

\section{Amostra M-5}

As imagens obtidas (Prancha 14) para esta amostra correspondem também a uma associação complexa de calcopirita com pirrotita, cubanita e mackinawita (intercrescimento de tipo: [(cp/po:1b)/cb:3a]/mck:1e), mas representativa da zona de alteração de tipo propílicapotássica. A exemplo do caso anterior a distribuição de $\mathrm{S}, \mathrm{Fe}$ e $\mathrm{Cu}$ destaca a presença de calcopirita, cubanita e pirrotita-mackinawita. Neste caso, vale a pena destacar o mapa do $\mathrm{Ni}$ onde pode ser caracterizada a mackinawita sendo diferenciada da pirrotita. O mapa do $\mathrm{Zn}$ sugere que este elemento esta presente na cubanita e menos freqüente na calcopirita. A área relativamente rica em Si corresponde a uma inclusão de uma fase filosilicática.

\section{Amostra Q-3}

Esta amostra representa à zona de alteração potássica-propílica. Na prancha 15 apresentamse duas inclusões simples em pirita, compostas de calcopirita e cubanita (cb/cp:3b) à esquerda e de calcopirita e mackinawita (cp/mck:4f) à direita, respectivamente. O Zn sugere estar presente na cubanita e calcopirita. Neste caso a morfologia das inclusões é subarredondada a diferença dos casos anteriores onde são mais ovais.

\section{Amostra F-2}

Representa também zonas de alteração potássica-propílica. A inclusão apresenta intercrescimento do tipo: [(cp/po:1b)/cb:3a]/mck:1e, complexo, com participação de calcopirita, pirrotita, cubanita e mackinawita (Prancha 16). Os mapas composicionais para S, Cu, Fe, Zn e Si são similares aos casos anteriores. Neste caso vale a pena destacar o mapa do Ni, o qual permite separar claramente mackinawita dos outros minerais especialmente da pirrotita.

\section{Amostras B-1 e J-4}

Estas duas amostras apresentam inclusões com intercrescimento simples, de tipo cp/mck:1b (amostra B-1) entre calcopirita e mackinawita e complexos, de tipo (cp/cb:3a)/po:1e (amostra J-4) entre calcopirita, cubanita e pirrotita presentes nas zonas de alteração propílica-potássica e fílica-propílica respectivamente. Imagens ópticas e BSE são apresentadas na Prancha 17; nestas 
últimas imagens, os minerais de pirrotita, cubanita e makinawita, podem ser reconhecidos pelas tonalidades de cinza, ou seja, quem é mais clara é a calcopirita seguida pela cubanita e finalmente pela pirrotita e mackinawita, ambas com tonalidades de cinza similares. Para estas amostras não foram obtidas imagens de raios $\mathrm{X}$, apenas análises pontuais ( $c f$. item seguinte). 


\section{PRANCHA 12}
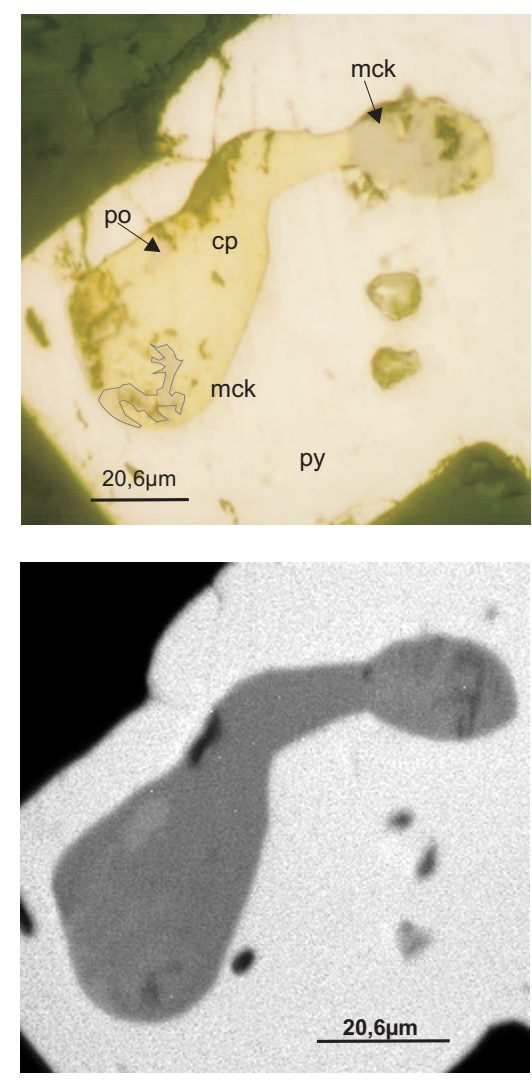

S

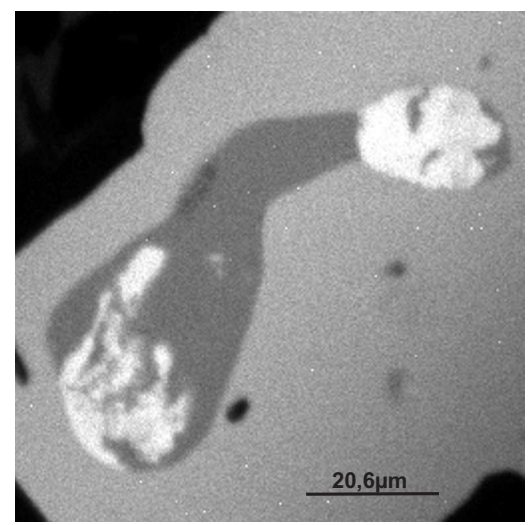

$\mathrm{Fe}$

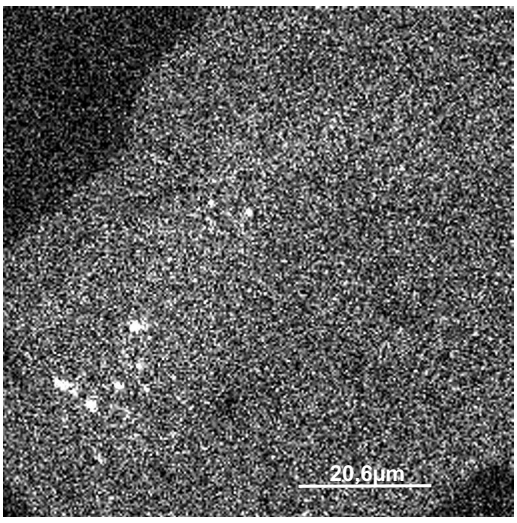

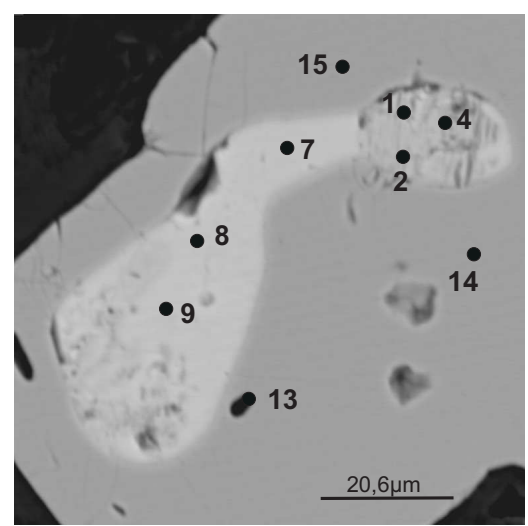
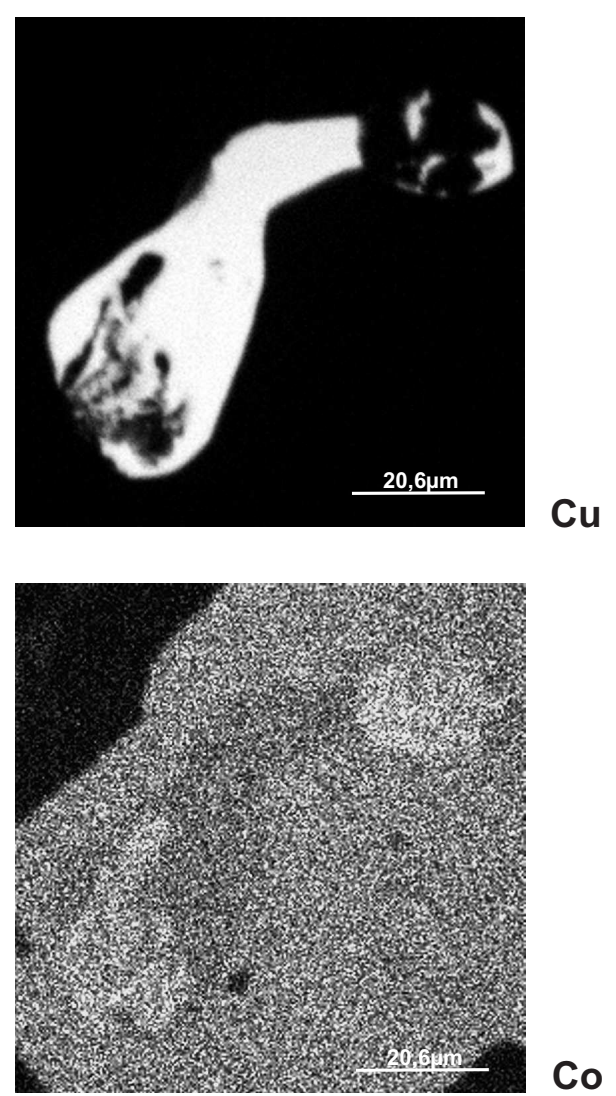

Co

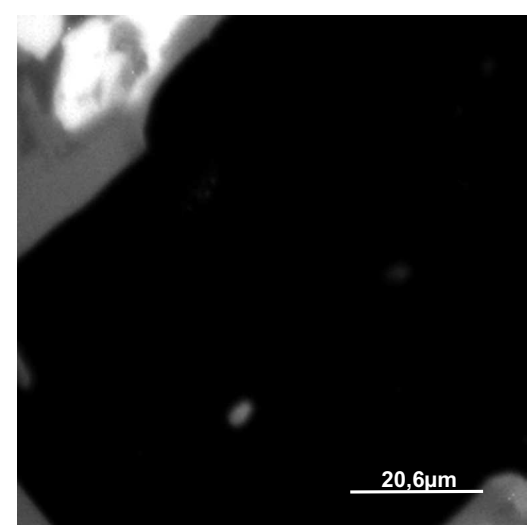

Si 


\section{PRANCHA 13}
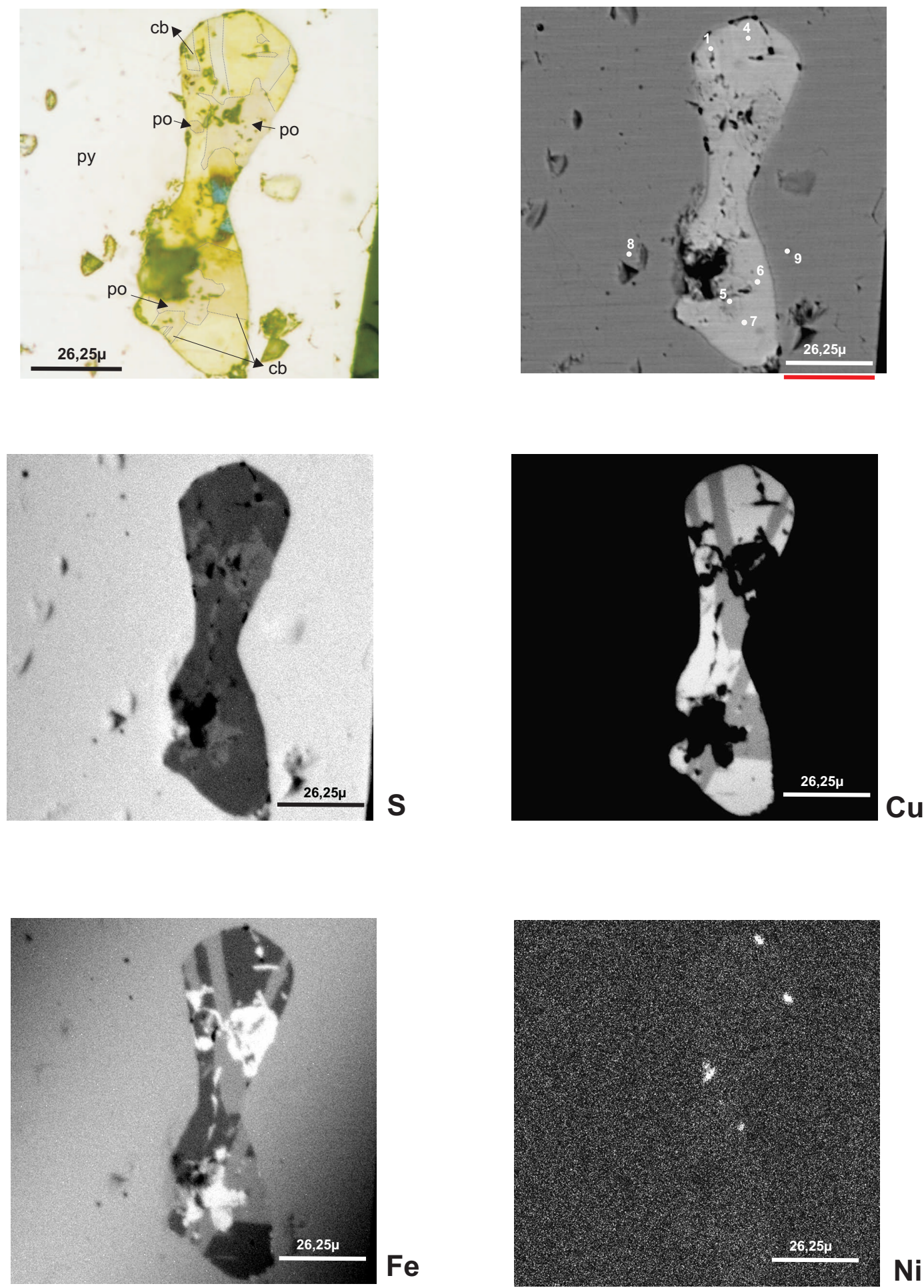

$\mathrm{Ni}$ 


\section{PRANCHA 14}
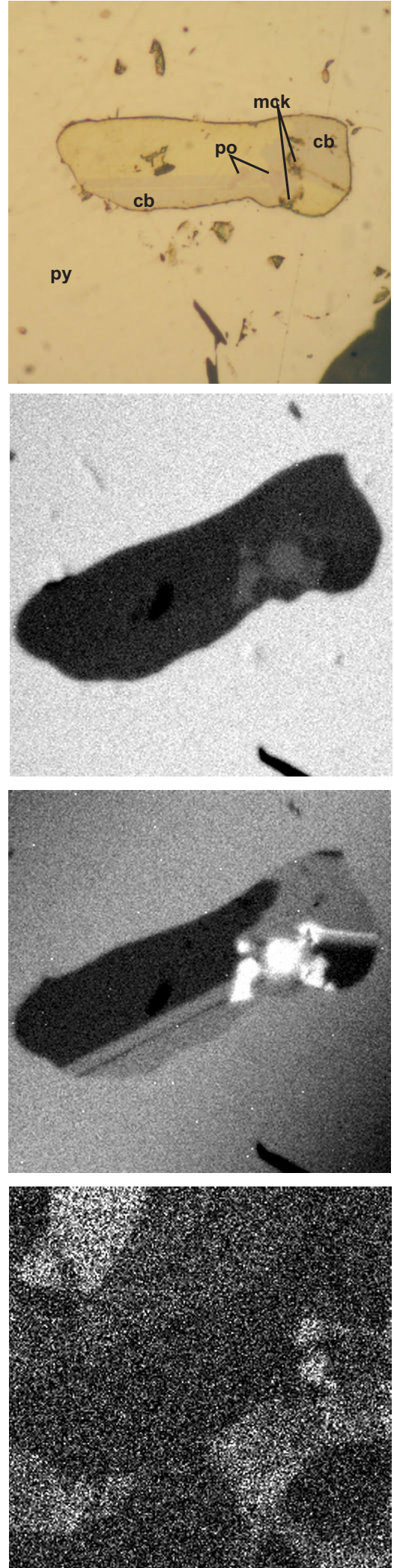
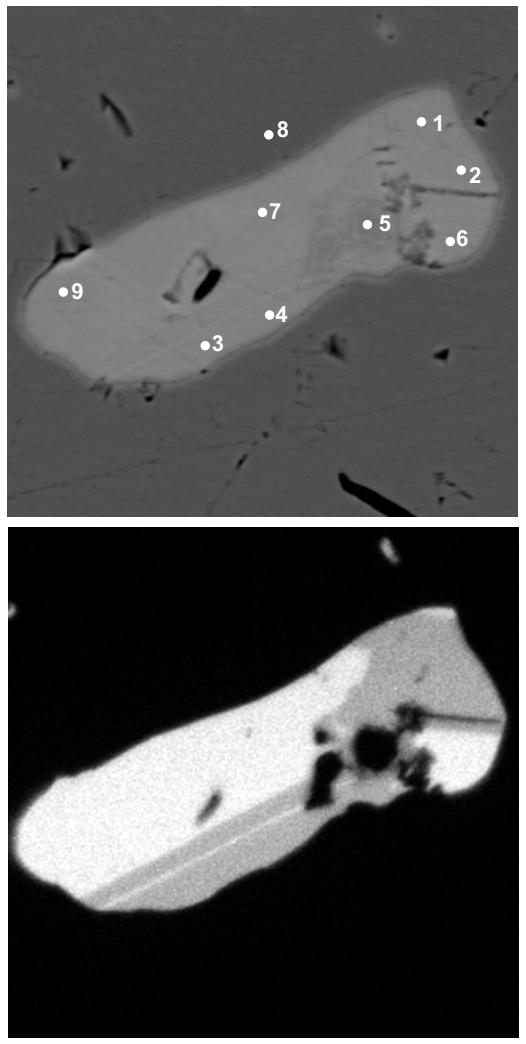

$\mathrm{Cu}$

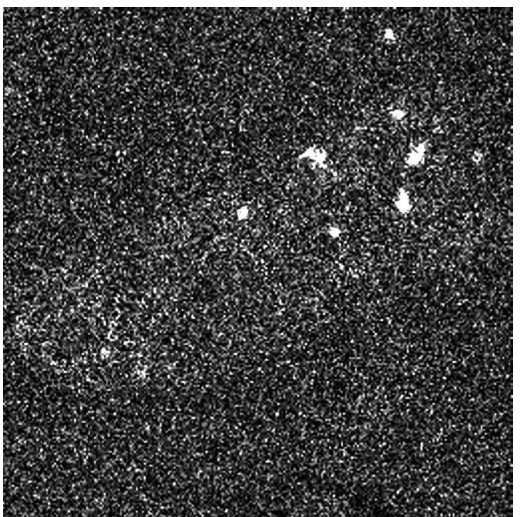

$\mathrm{Zn}$

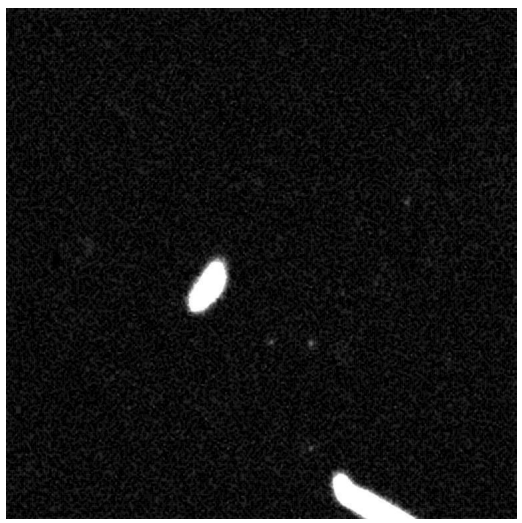

Si 


\section{PRANCHA 15}
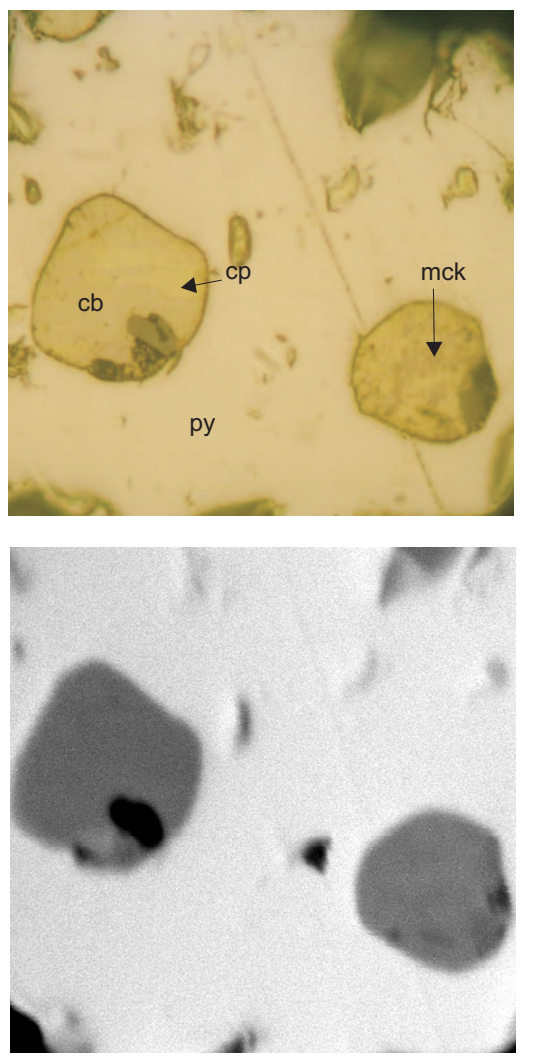

S

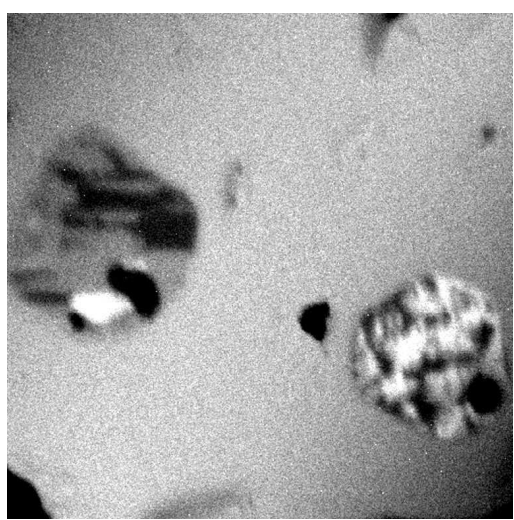

$\mathrm{Fe}$

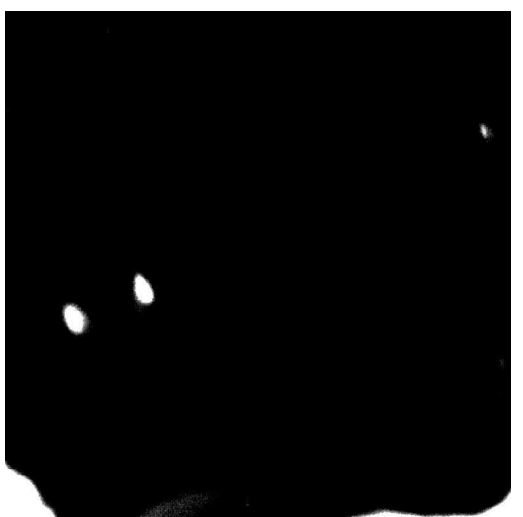

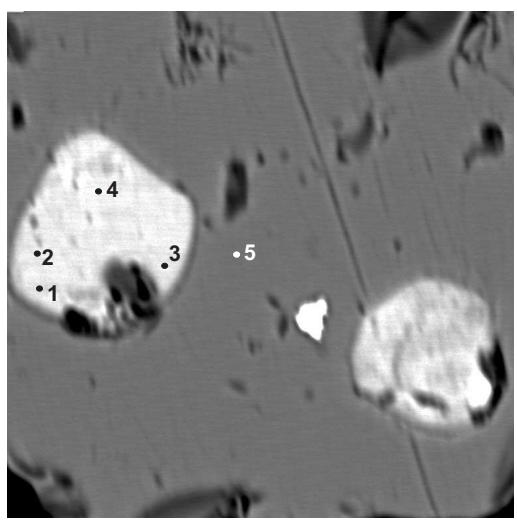
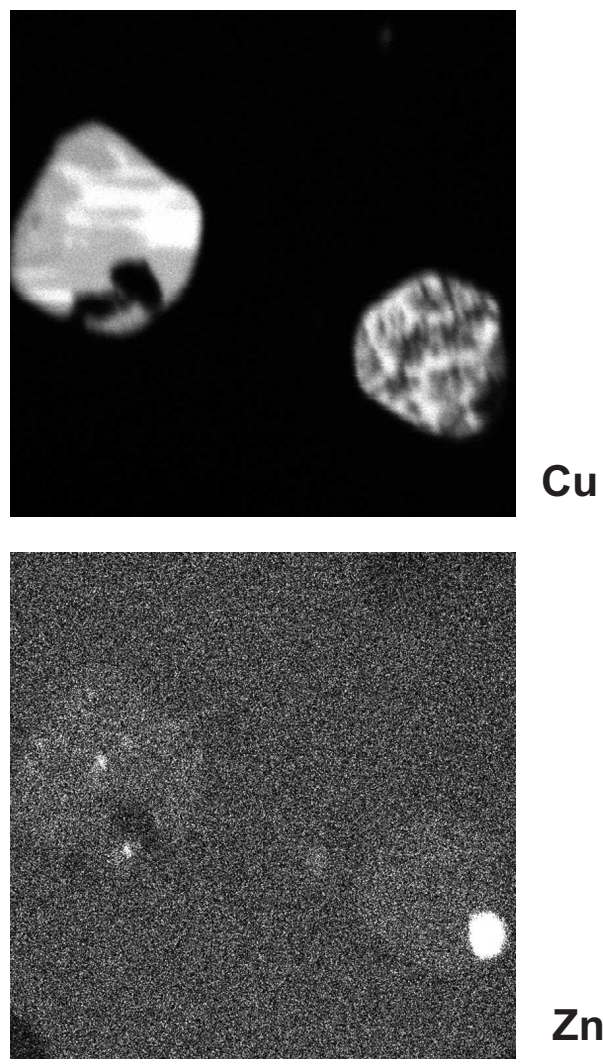

$\mathrm{Zn}$ 


\section{PRANCHA 16}
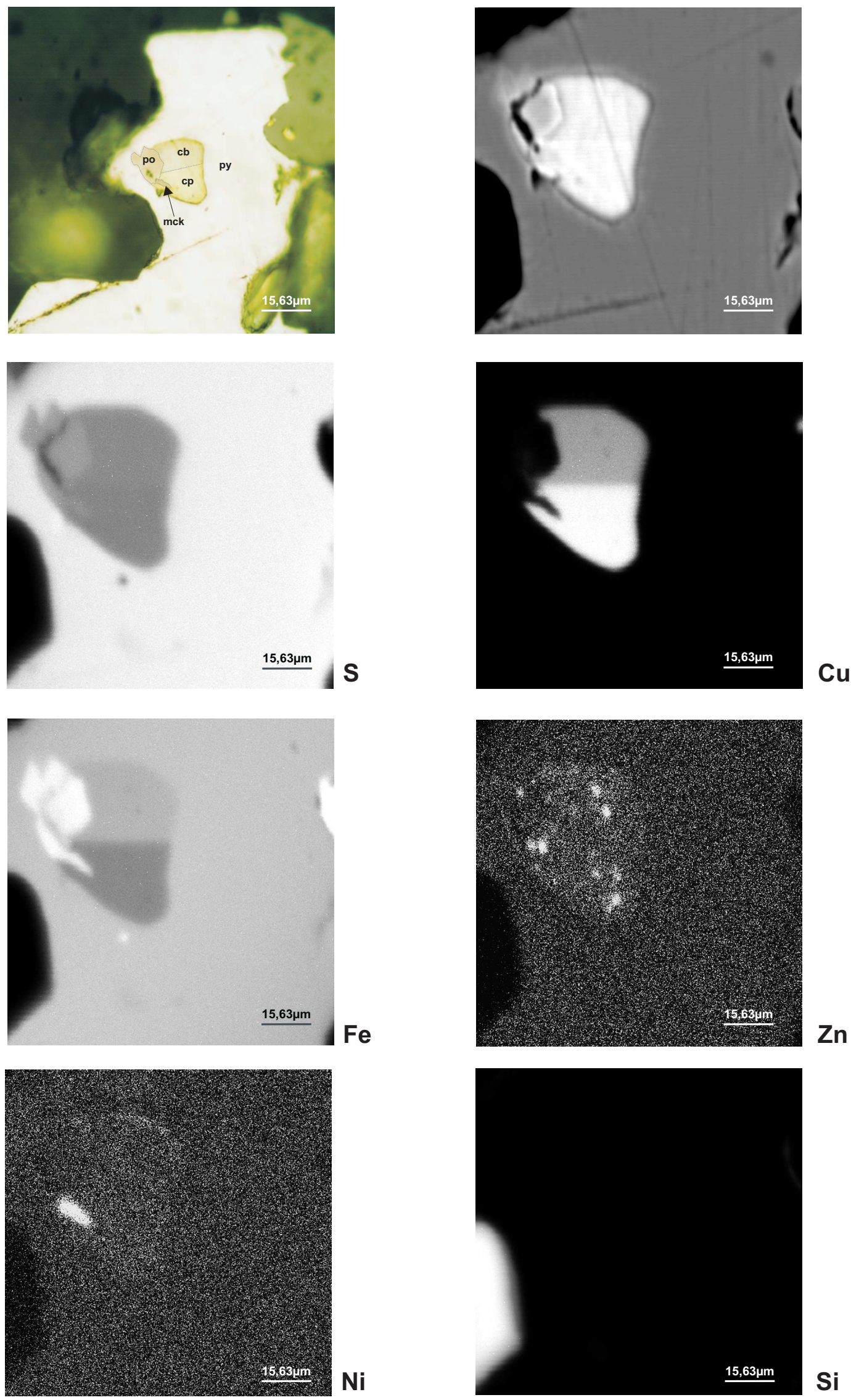


\section{PRANCHA 17}
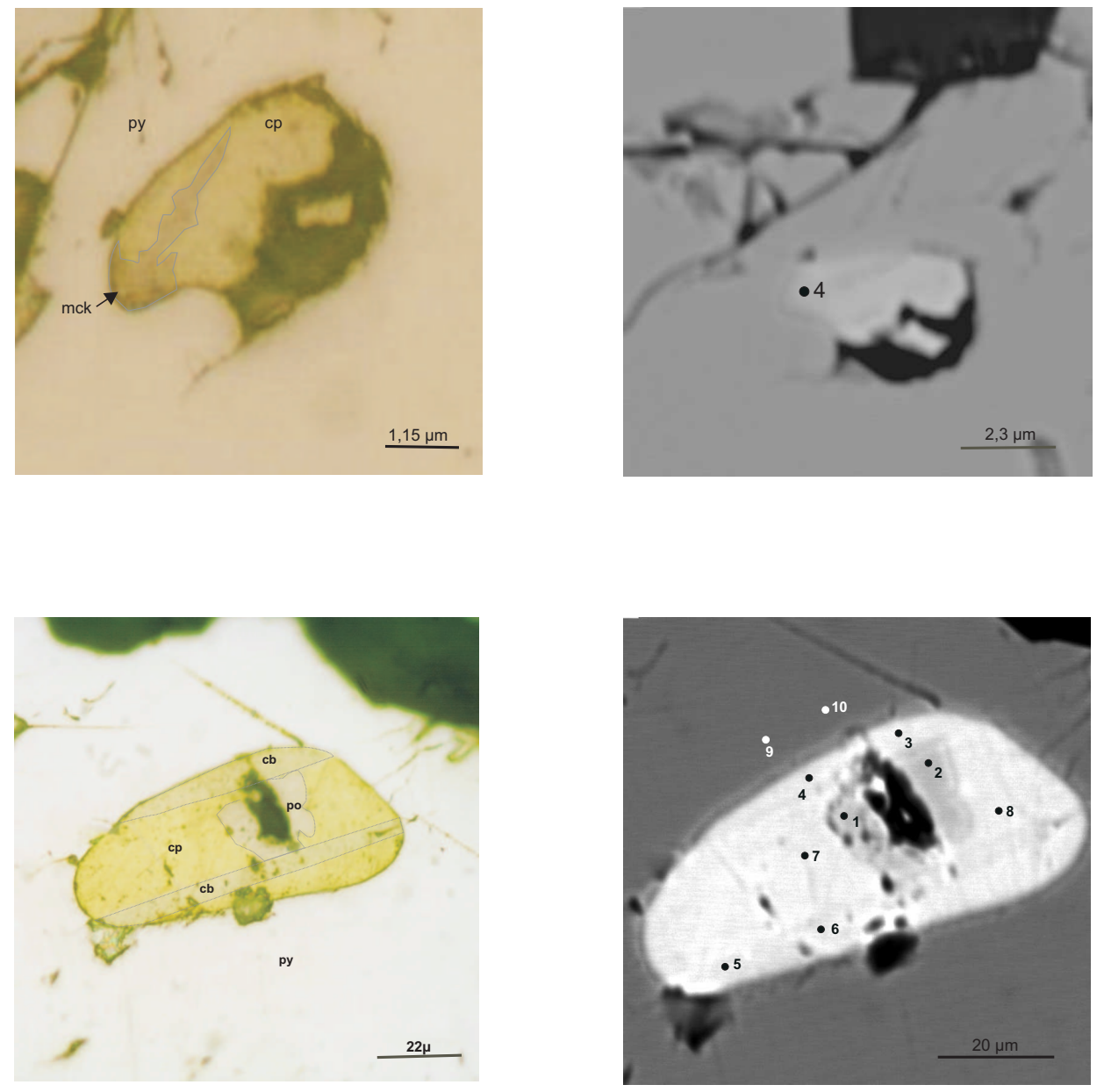


\subsubsection{Análises pontuais quantitativas}

Análises pontuais (WDS) foram obtidas para a caracterização química geral dos sulfetos que formam os intercrescimentos e também para examinar e identificar eventuais variações composicionais nas diferentes zonas de alteração hidrotermal. As amostras foram escolhidas considerando o tipo de alteração hidrotermal dominante e também amostras nas quais as inclusões menores apresentassem dimensões suficientes para análises adequadas, uma vez que algumas inclusões são tipicamente diminutas, fato que dificulta análises quantitativas de boa qualidade. Os resultados são comparados com minerais descritos e analisados em trabalhos com análises químicas e de microssonda eletrônica em sulfetos.

Ao total foram selecionadas e analisadas cerca de 25 inclusões de 12 amostras, utilizandose como referência para a localização de pontos os mapas composicionais obtidos, uma vez que a cobertura de $\mathrm{C}$, necessária para as análises quantitativas oblitera significativamente as tonalidades de cor das fases estudadas quando observadas opticamente na microssonda eletrônica e também diversas das inclusões estudadas apresentam dimensões diminutas de análise difícil. Os resultados melhores e mais representativos foram obtidos para as amostras B-1, D-5, F-1 do perfil 1, J-4 do perfil 2 e M-5 e Q-3 do perfil 3; diversos resultados não foram considerados porque provavelmente representam situações em que não se conseguiu focar o feixe eletrônico em uma mesma fase homogênea. A seguir nas figuras 7.1 a 7.3 , são mostrados os perfis com a localização das amostras:

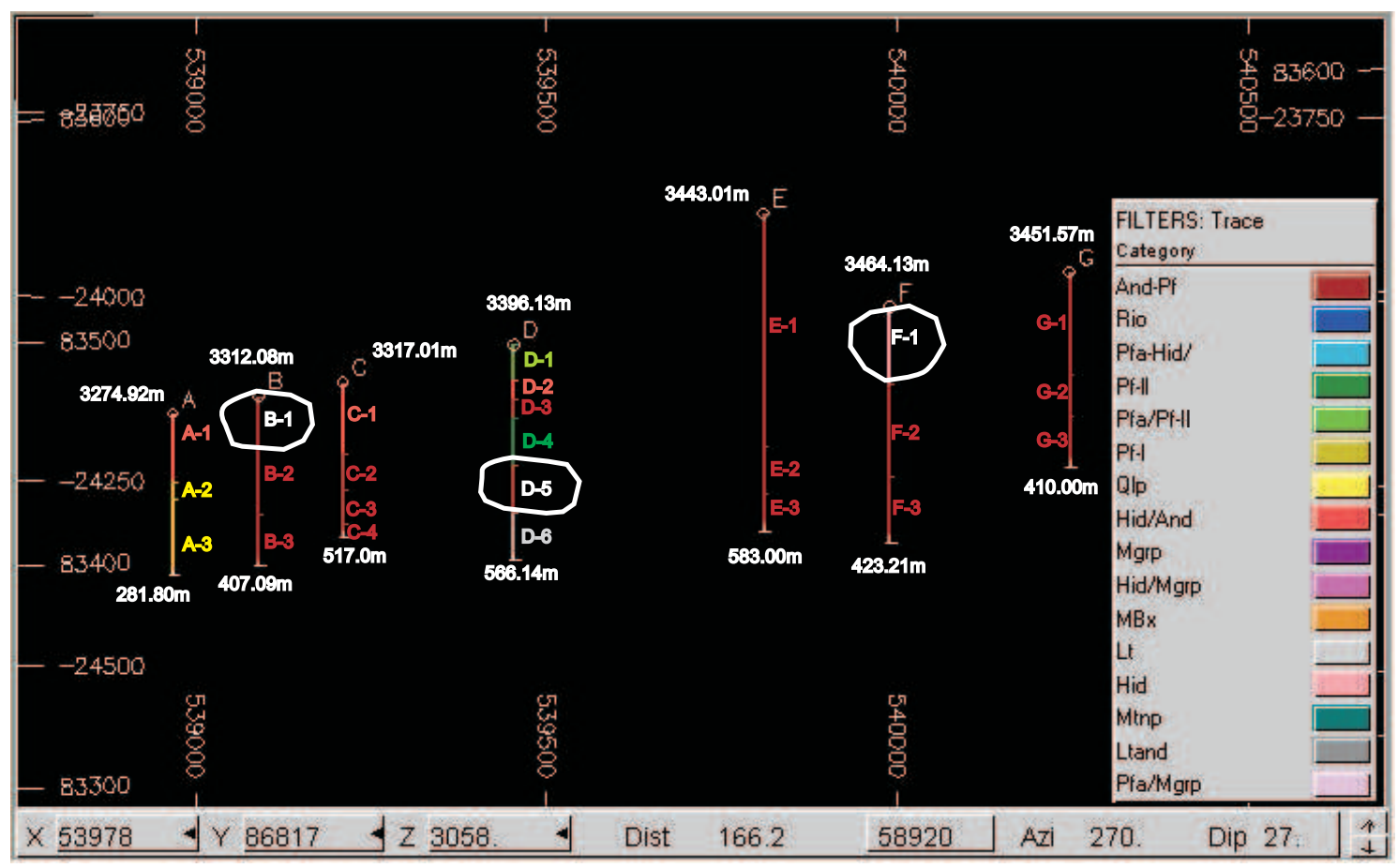

Figura 7.1: Perfil 1 com a seleção dos tipos de rocha (B-1, D-5 e F-1) mais representativas as quais deram melhores resultados nos analises da microssonda eletrônica. Cotas e profundidades são dadas na parte superior e inferior de cada furo respectivamente, as coordenadas são representadas em UTM. 


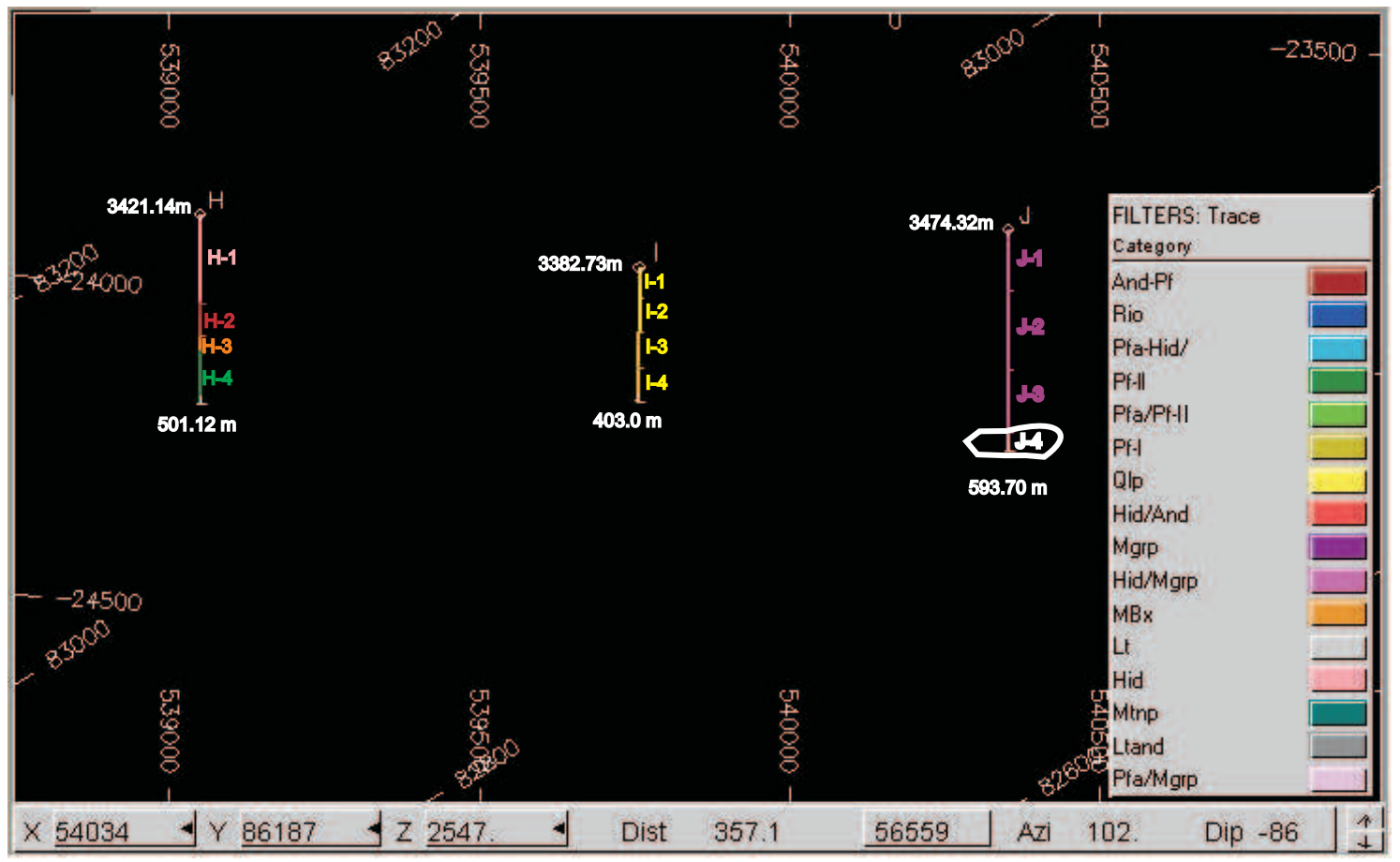

Figura 7.2: Perfil 2 com a seleção da rocha J-4 mais representativa a qual mostro melhores resultados nos analises da microssonda eletrônica. Cotas e profundidades são dadas na parte superior e inferior de cada furo respectivamente, as coordenadas são representadas em UTM.

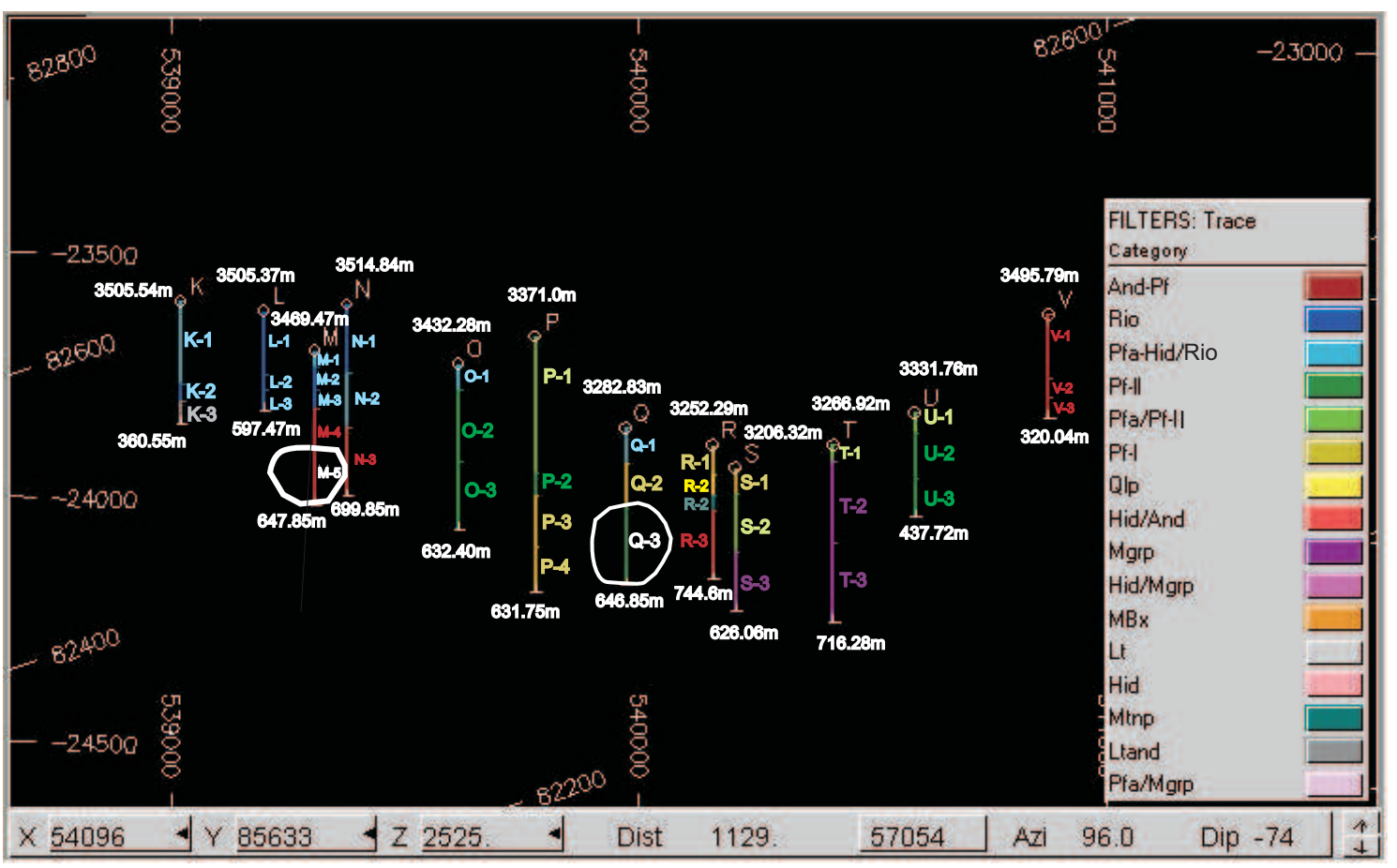

Figura 7.3: Perfil 3 com a seleção das rochas M-5 e Q-3 mais representativas as quais mostraram melhores resultados nos analises da microssonda eletrônica. Cotas e profundidades são dadas na parte superior e inferior de cada furo respectivamente, as coordenadas são representadas em UTM. 
Além do $\mathrm{Fe}, \mathrm{Cu}, \mathrm{S}$ que constituem os elementos essenciais dos minerais estudados, foram analisados também Co, Ni, Mg, Ca, Mn, Zn, Au, Ag, As e Si. Mg, Ca e Mn também foram analisados por serem constituintes importantes da vallerita $\left(\left(\mathrm{CuFeS}_{2}\right) \mathrm{n}\left(\mathrm{Mg}, \mathrm{Ca}, \mathrm{Fe}, \mathrm{Ni}, \mathrm{Co}, \mathrm{Mn}(\mathrm{OH})_{2}\right)\right.$ $\left.\mathrm{m}\left(\mathrm{Al}(\mathrm{OH})_{3}\right)\right)$, mineral com propriedades ópticas muito semelhantes às da mackinawita (Evans, 1964). Au e Zn são elementos que estão freqüentemente associados ao sistema Fe-Cu-S (Simon et al., 2000; Lusk \& Calder, 2004), enquanto Ag e As são elementos relativamente comuns em pirita, ocorrendo em quantidades menores ou de traços. Os resultados analíticos obtidos para as fases minerais analisadas são apresentados e discutidos a seguir. A localização dos pontos analisados em cada caso é apresentada nas pranchas 12 a 17 ( $c f$. item anterior).

\section{Pirita $\left(\mathrm{FeS}_{2}\right)$ :}

Foram obtidas nove análises de cristais de pirita representativas das zonas de alteração potássica-propílica (amostras D-5 e Q-3), propílica-potássica (Amostra M-5), potássica-propílica/fílica (amostra F-1) e fílica-propílica (amostra J-4).

Os resultados obtidos são apresentados na Tabela 7.2. Observa-se em geral que os cristais de pirita analisados apresentam composições homogêneas que se aproximam muito da fórmula ideal $\mathrm{FeS}_{2}$. Estas composições são muito similares nas proporções de $\mathrm{Fe}$ e $\mathrm{S}$ quando comparadas com piritas de outros tipos de jazidas obtidas por Gomez \& Fabas (2006) para mina de Sn em granito de muscovita, Meldrum (1998) para mina de $\mathrm{Ni}$ e $\mathrm{Cu}$ em piroxenitos-peridotitos serpentinizados e Anthony et al. (1990) que reporta análises químicas convencionais de pirita na mina Elba, Italia. É importante observar que Gomez \& Fabas (2006) também reportam valores significativos para Zn, Ag As e Mn. As proporções entre Fe e S aproximam-se dos valores ideais observados e são ligeiramente maiores apenas nas amostras F-1 e J-4. Entre os elementos traços, a maioria está ausente ou abaixo do limite de detecção; merece destaque apenas os teores de $\mathrm{Cu}$ (0,04 - 0,13,\% em peso), Ni, que atinge 0,10 na amostra M-5 e os teores em Au (0,07 e 0,15 $\%$ nas amostras D-5 e J-4, respectivamente. Os valores simultaneamente mais altos de $\mathrm{Ni}$ e $\mathrm{Cu}$ são observados na amostra M-5 da zona propílica-potássica, enquanto os teores mais altos em $\mathrm{Au}$ aparecem nas zonas potássica-propílica e, particularmente, na fílica-propílica.

\section{Calcopirita $\left(\mathrm{CuFeS}_{2}\right)$ :}

Foram obtidas doze análises pontuais de cristais de calcopirita presentes sob a forma de cinco inclusões sólidas em pirita de cinco amostras, representativas das zonas de alteração potássicapropílica (amostras D-5, Q-3), propílica-potássica (amostra M-5), potássica-propílica/fílica (amostra F-1) e fílica-propílica (amostra J-4). Os resultados analíticos são apresentados na Tabela 7.3.

As análises obtidas se aproximam muito da composição ideal esperada para calcopirita. Entre os elementos traços apenas o $\mathrm{Zn}$ e o $\mathrm{Au}$ merecem destaque, por se apresentarem em quantidades superiores aos do limite de detecção do método; vale a pena destacar que estes 
Tabela 7.2: (A) Análises químicas pontuais (WDS) para a pirita hospedeira de inclusões sólidas (bd = abaixo do limite de detecção). Análises de piritas da literatura: (a) pirita em granito de muscovita (análises WDS), (b) em piroxenitos-peridotitos serpentinizados (análises WDS) e (c) em rocha hospedeira não descrita na zona da mina Elba, Italia (análises químicas convencionais). (B) Fórmula estrutural.

\begin{tabular}{|c|c|c|c|c|c|c|c|c|c|c|c|c|c|c|c|}
\hline \multirow{2}{*}{ Perfil } & \multirow{2}{*}{$\begin{array}{c}\text { Código da } \\
\text { amostra (análise } \\
\text { pontual) }\end{array}$} & \multirow{2}{*}{$\begin{array}{c}\text { Tipo de } \\
\text { alteração }\end{array}$} & \multicolumn{13}{|c|}{ Elementos analisados (\% peso) } \\
\hline & & & $\mathrm{Fe}$ & $\mathrm{Ni}$ & $\mathrm{Cu}$ & S & $\mathrm{Mg}$ & $\mathrm{Zn}$ & $\mathrm{Ca}$ & Co & $\mathrm{Ag}$ & As & $\mathrm{Au}$ & $\mathrm{Mn}$ & $\mathrm{Si}$ \\
\hline$S-1$ & D-5(13) & K-P & 46.41 & $\mathrm{bd}$ & 0.03 & 52.99 & $\mathrm{bd}$ & $\mathrm{bd}$ & $\mathrm{bd}$ & bd & $\mathrm{bd}$ & bd & 0.04 & $\mathrm{bd}$ & $\mathrm{bd}$ \\
\hline $\mathrm{S}-1$ & $D-5(14)$ & K-P & 46.41 & $\mathrm{bd}$ & 0.05 & 53.13 & $\mathrm{bd}$ & $\mathrm{bd}$ & $\mathrm{bd}$ & $\mathrm{bd}$ & $\mathrm{bd}$ & bd & 0.07 & $\mathrm{bd}$ & $\mathrm{bd}$ \\
\hline$S-1$ & $D-5(15)$ & K-P & 46.34 & $\mathrm{bd}$ & \begin{tabular}{|l|l|}
0.04 \\
\end{tabular} & 52.86 & $\mathrm{bd}$ & $\mathrm{bd}$ & $\mathrm{bd}$ & $\mathrm{bd}$ & $\mathrm{bd}$ & $\mathrm{bd}$ & $\mathrm{bd}$ & $\mathrm{bd}$ & $\mathrm{bd}$ \\
\hline $\mathrm{S}-3$ & $Q-3(5)$ & K-P & 46.05 & $\mathrm{bd}$ & 0.04 & 53.68 & $\mathrm{bd}$ & $\mathrm{bd}$ & $\mathrm{bd}$ & $\mathrm{bd}$ & $\mathrm{bd}$ & $\mathrm{bd}$ & $\mathrm{bd}$ & $\mathrm{bd}$ & $\mathrm{bd}$ \\
\hline S-3 & $M-5(8)$ & $\mathrm{P}-\mathrm{K}$ & 46.41 & 0.10 & 0.13 & 53.55 & $\mathrm{bd}$ & $\mathrm{bd}$ & $\mathrm{bd}$ & $\mathrm{bd}$ & $\mathrm{bd}$ & $\mathrm{bd}$ & $\mathrm{bd}$ & $\mathrm{bd}$ & $\mathrm{bd}$ \\
\hline$S-1$ & $F-1(8)$ & $K=P-F$ & 46.98 & $\mathrm{bd}$ & 0.04 & 53.02 & $\mathrm{bd}$ & $\mathrm{bd}$ & $\mathrm{bd}$ & $\mathrm{bd}$ & $\mathrm{bd}$ & $\mathrm{bd}$ & $\mathrm{bd}$ & $\mathrm{bd}$ & $\mathrm{bd}$ \\
\hline$S-1$ & $F-1(9)$ & $\mathrm{K}=\mathrm{P}-\mathrm{F}$ & 47.51 & $\mathrm{bd}$ & 0.09 & 53.18 & bd & $\mathrm{bd}$ & $\mathrm{bd}$ & $\mathrm{bd}$ & $\mathrm{bd}$ & $\mathrm{bd}$ & $b d$ & $\mathrm{bd}$ & $\mathrm{bd}$ \\
\hline$S-2$ & $J-4(9)$ & F-P & 47.19 & $\mathrm{bd}$ & 0.07 & 53.71 & $\mathrm{bd}$ & $\mathrm{bd}$ & $\mathrm{bd}$ & $\mathrm{bd}$ & $\mathrm{bd}$ & $\mathrm{bd}$ & 0.15 & $\mathrm{bd}$ & $\mathrm{bd}$ \\
\hline S-2 & $J-4(10)$ & F-P & 47.66 & $\mathrm{bd}$ & 0.04 & 53.16 & $\mathrm{bd}$ & bd & $\mathrm{bd}$ & bd & 0.03 & $\mathrm{bd}$ & $\mathrm{bd}$ & $\mathrm{bd}$ & $\mathrm{bd}$ \\
\hline \multicolumn{2}{|c|}{ Gomes \& Fabas. (2006) } & a & 46.30 & & & 52.85 & & 0.09 & & & 0.06 & 0.30 & & 0.05 & \\
\hline \multicolumn{2}{|c|}{ Meld rum (1998) } & $\mathrm{b}$ & 46.07 & & & 52.49 & & & & & & & & & \\
\hline Antho & ny et. al. (1990) & c & \begin{tabular}{|l|}
46.49 \\
\end{tabular} & & & 53.49 & & & & & & & & & \\
\hline \multicolumn{16}{|c|}{$\begin{array}{l}a=\text { Cámeca Camebax electron microprobe, mina Ervedosa - Portugal } \\
b=\text { electron microprobe mina Rankin Inlet Nunavut - Canada } \\
\mathrm{c}=\text { chemistry, Elva Italy remainder } 0,04 \% \mathrm{SiO}_{2} \text {. }\end{array}$} \\
\hline \multicolumn{16}{|l|}{ (B) } \\
\hline \multirow[b]{2}{*}{ Perfil } & \multirow{2}{*}{$\begin{array}{c}\text { Código da } \\
\text { amostra (análise } \\
\text { pontual) }\end{array}$} & \multirow[b]{2}{*}{$\begin{array}{c}\text { Tipo de } \\
\text { alteração }\end{array}$} & \multicolumn{13}{|c|}{ Cátions calculados para $2 \mathrm{~S}$} \\
\hline & & & $\mathrm{Fe}$ & $\mathrm{Ni}$ & $\mathrm{Cu}$ & S & $\mathrm{Mg}$ & $\mathrm{Zn}$ & $\mathrm{Ca}$ & Co & $\mathrm{Ag}$ & As & $\mathrm{Au}$ & $\mathrm{Mn}$ & $\mathrm{Si}$ \\
\hline $\mathrm{S}-1$ & $\mathrm{D}-5(13)$ & K-P & 1.006 & ---- & \begin{tabular}{|l|}
0.000 \\
\end{tabular} & 2.000 & ---- & ---- & ---- & ---- & ---- & ---- & 0.001 & ---- & ---- \\
\hline $\mathrm{S}-1$ & $D-5(14)$ & K-P & 1.003 & ---- & 0.001 & 2.000 & ---- & ---- & ---- & ---- & $\begin{array}{l}--- \\
\end{array}$ & ---- & 0.000 & ---- & ---- \\
\hline S-1 & D-5(15) & K-P & 1.007 & ---- & 0.001 & 2.000 & ---- & ---- & ---- & ---- & ---- & ---- & --- & ---- & ---- \\
\hline $\mathrm{S}-3$ & $Q-3(5)$ & K-P & 0.985 & ---- & 0.001 & 2.000 & ---- & ---- & ---- & ----- & ---- & ---- & ---- & ---- & ---- \\
\hline S-3 & $M-5(8)$ & $\mathrm{P}-\mathrm{K}$ & 0.995 & 0.002 & 0.002 & 2.000 & ---- & ---- & ---- & ---- & ---- & ---- & ---- & ---- & ---- \\
\hline $\mathrm{S}-1$ & $F-1(8)$ & $\mathrm{K}=\mathrm{P}-\mathrm{F}$ & 1.017 & ---- & 0.001 & 2.000 & ---- & ---- & ---- & ---- & ---- & ---- & ----- & ---- & ---- \\
\hline $\mathrm{S}-1$ & $F-1(9)$ & $\mathrm{K}=\mathrm{P}-\mathrm{F}$ & 1.026 & ---- & 0.002 & 2.000 & ---- & ---- & ---- & ---- & $\overline{----}$ & ---- & \begin{tabular}{|l|}
---- \\
\end{tabular} & ---- & ---- \\
\hline $\mathrm{S}-2$ & $\mathrm{~J}-4(9)$ & F-P & 1.009 & ---- & 0.001 & 2.000 & ---- & ---- & ---- & ---- & ---- & ---- & 0.001 & ---- & ---- \\
\hline $\mathrm{S}-2$ & $J-4(10)$ & F-P & 1.029 & ---- & 0.001 & 2.000 & ---- & ---- & ---- & ---- & 0.000 & ---- & ---- & ---- & ---- \\
\hline
\end{tabular}

elementos ocorrem em abundâncias significativas apenas em exemplares das zonas de alteração potássica-propílica e fílica-propílica. De acordo com Cabri et al. (1984), Ni e Co ocorrem em quantidades de traços em calcopirita de jazidas de sulfetos de $\mathrm{Cu}-\mathrm{Ni}$ em complexos máficos estratiformes em Sudbury - Canada, fato não observada nas análises de Cuajone, em que o Ni encontra-se abaixo do limite de detecção.

\section{Cubanita $\left(\mathrm{CuFe}_{2} \mathrm{~S}_{3}\right)$ :}

Foram obtidas doze análises pontuais de cubanita presentes como inclusões em calcopirita, correspondentes às zonas de alteração potássica-propílica (amostra Q-3), propílica-potássica (amostra M-5), potássica-propílica/fílica (amostra F-1) e fílica-propílica (amostra J-4). Os resultados são apresentados na Tabela 7.4.

Algumas análises resultaram em baixos fechamentos analíticos (97,298,2 \% em peso), fato atribuído a dificuldade de se focalizar o feixe neste mineral devido às suas dimensões e/ou à problemas de metalização. Os resultados mostram que as proporções de Fe, $\mathrm{Cu}$ e S são próximos as ideais esperadas. Teores em traço de Au (0,16 -0,30 \%) são característicos da amostra J-4, da zona fílica-propílica, enquanto Ag aparece de forma significativa apenas em duas análises da zona propílica-potássica e Zn em alguns cristais de todas as zonas consideradas com exceção 
Tabela 7.3: Análises químicas pontuais (WDS) para inclusões de calcopirita (bd = abaixo do limite de detecção). Análises de calcopiritas da literatura: (a,b) em piroxenita-peridotita serpentinizada (análises WDS), (c) rocha hospedeira não descrita, mina Western, Vancouver Island, British Columbia, Canadá (análises WDS), (d) para $\mathrm{CuFeS}_{2}$ (análises químicas convencionais), (e) Mina Washi-aimori, Iwate Japan (análises químicas convencionais) e (f) em rochas de complexos máficos estratiformes, jazidas de sulfetos de Cu-Ni, Sudbury - Canada (análises químicas convencionais). (B) Fórmula estrutural.

\begin{tabular}{|c|c|c|c|c|c|c|c|c|c|c|c|c|c|c|c|c|c|}
\hline \multirow[b]{2}{*}{ Perfil } & \multirow{2}{*}{$\begin{array}{c}\text { Código } \\
\text { da } \\
\text { amostra }\end{array}$} & \multirow{2}{*}{$\begin{array}{l}\text { Tipo de } \\
\text { alteração }\end{array}$} & \multicolumn{13}{|c|}{ Elementos analisados (\% peso) } & \multirow{2}{*}{$\begin{array}{l}\text { Res.(ácido } \\
\text { insolúvel } \\
\text { resíduo) }\end{array}$} & \multirow[b]{2}{*}{ Total } \\
\hline & & & $\mathrm{Fe}$ & $\mathrm{Ni}$ & $\mathrm{Cu}$ & s & $\mathrm{Mg}$ & $\mathrm{Zn}$ & $\mathrm{Ca}$ & Co & $\mathrm{Ag}$ & As & $\mathrm{Au}$ & $\mathrm{Mn}$ & $\mathrm{Si}$ & & \\
\hline $\mathrm{S}-1$ & $\mathrm{D}-5(7)$ & K-P & 30.24 & $\mathrm{bd}$ & 33.32 & 34.65 & bd & $\mathrm{bd}$ & bd & bd & $\mathrm{bd}$ & $\mathrm{bd}$ & 0.07 & $\mathrm{bd}$ & bd & & 98.30 \\
\hline $\mathrm{S}-1$ & $\mathrm{D}-5(8)$ & K-P & 30.46 & $\mathrm{bd}$ & 32.93 & 34.06 & bd & bd & bd & bd & 0.03 & $\mathrm{bd}$ & 0.06 & $\mathrm{bd}$ & $\mathrm{bd}$ & & 97.55 \\
\hline $\mathrm{S}-1$ & $\mathrm{D}-5(9)$ & K-P & 30.30 & $\mathrm{bd}$ & 32.35 & 34.49 & $\mathrm{bd}$ & 0.08 & bd & $\mathrm{bd}$ & 0.03 & $\mathrm{bd}$ & $\mathrm{bd}$ & bd & bd & & 97.26 \\
\hline $\mathrm{S}-3$ & Q-3 (4) & K-P & 30.34 & $\mathrm{bd}$ & 32.88 & 34.69 & bd & 0.06 & bd & bd & $\mathrm{bd}$ & $\mathrm{bd}$ & bd & $\mathrm{bd}$ & $\mathrm{bd}$ & & 98.01 \\
\hline $\mathrm{S}-3$ & $\mathrm{M}-5(9)$ & $\mathrm{P}-\mathrm{K}$ & 30.18 & $\mathrm{bd}$ & 32.92 & 34.61 & $\mathrm{bd}$ & $\mathrm{bd}$ & $\mathrm{bd}$ & $\mathrm{bd}$ & $\mathrm{bd}$ & $\mathrm{bd}$ & $\mathrm{bd}$ & $\mathrm{bd}$ & $\mathrm{bd}$ & & 97.75 \\
\hline $\mathrm{S}-3$ & $\mathrm{M}-5(6)$ & $\mathrm{P}-\mathrm{K}$ & 29.82 & $\mathrm{bd}$ & 32.77 & 34.42 & $\mathrm{bd}$ & $b d$ & bd & $\mathrm{bd}$ & $\mathrm{bd}$ & $\mathrm{bd}$ & $\mathrm{bd}$ & bd & $\mathrm{bd}$ & & 97.06 \\
\hline $\mathrm{S}-3$ & M-5(7) & P-K & 30.11 & $\mathrm{bd}$ & 32.96 & 34.91 & $\mathrm{bd}$ & $b d$ & bd & $\mathrm{bd}$ & $\mathrm{bd}$ & $\mathrm{bd}$ & $\mathrm{bd}$ & $\mathrm{bd}$ & $\mathrm{bd}$ & & 98.02 \\
\hline $\mathrm{S}-1$ & $\mathrm{~F}-1(1)$ & $K(i)=P-F$ & 29.90 & $\mathrm{bd}$ & \begin{tabular}{|l|}
33.71 \\
\end{tabular} & 35.13 & $\mathrm{bd}$ & $\mathrm{bd}$ & $\mathrm{bd}$ & $\mathrm{bd}$ & $\mathrm{bd}$ & $\mathrm{bd}$ & 0.12 & $\mathrm{bd}$ & $\mathrm{bd}$ & & 98.92 \\
\hline $\mathrm{S}-1$ & $\mathrm{~F}-1(4)$ & $K(i)=P-F$ & 30.30 & $\mathrm{bd}$ & 33.93 & 34.68 & bd & $b d$ & $\mathrm{bd}$ & $\mathrm{bd}$ & $\mathrm{bd}$ & $\mathrm{bd}$ & $\mathrm{bd}$ & $\mathrm{bd}$ & $\mathrm{bd}$ & & 98.95 \\
\hline$S-1$ & $F-1(7)$ & $K(i)=P-F$ & 30.18 & $\mathrm{bd}$ & 33.20 & 34.37 & $\mathrm{bd}$ & $\mathrm{bd}$ & $\mathrm{bd}$ & $\mathrm{bd}$ & $\mathrm{bd}$ & $\mathrm{bd}$ & $b d$ & $\mathrm{bd}$ & $\mathrm{bd}$ & & 97.77 \\
\hline $\mathrm{S}-2$ & $\mathrm{~J}-4(7)$ & F-P & $\begin{array}{l}30.74 \\
\end{array}$ & $\mathrm{bd}$ & \begin{tabular}{|l|}
32.69 \\
\end{tabular} & 34.98 & $\mathrm{bd}$ & 0.09 & $\mathrm{bd}$ & $\mathrm{bd}$ & $\mathrm{bd}$ & $\mathrm{bd}$ & 0.27 & $\mathrm{bd}$ & $\mathrm{bd}$ & & 98.82 \\
\hline$S-3$ & $J-4(8)$ & $F-P$ & $\begin{array}{l}30.55 \\
\end{array}$ & $\mathrm{bd}$ & \begin{tabular}{|l|}
32.39 \\
\end{tabular} & 34.50 & $\mathrm{bd}$ & $b d$ & $\mathrm{bd}$ & $\mathrm{bd}$ & $\mathrm{bd}$ & $\mathrm{bd}$ & 0.08 & $\mathrm{bd}$ & $\mathrm{bd}$ & & 97.54 \\
\hline \multirow{2}{*}{\multicolumn{2}{|c|}{ Meldrum (1998) }} & $a$ & 30.52 & & \begin{tabular}{|l|}
34.23 \\
\end{tabular} & 35.09 & & & & & & & & & & & 99.83 \\
\hline & & b & 29.27 & & 32.28 & 34.46 & & & & & & & & & & & 96.00 \\
\hline \multirow{2}{*}{\multicolumn{2}{|c|}{$\begin{array}{c}\text { Anthony et. al. } \\
(1990)\end{array}$}} & c & 31.00 & & 35.03 & 34.96 & & & & & & & & & & & 100.99 \\
\hline & & $d$ & 30.43 & & 34.63 & 34.94 & & & & & & & & & & & 100.00 \\
\hline \multicolumn{2}{|c|}{$\begin{array}{l}\text { Mizota et. al. } \\
(1985)\end{array}$} & e & 30.55 & & 34.00 & 34.52 & & & & & & & & & & 0.26 & 99.38 \\
\hline \multicolumn{2}{|c|}{$\begin{array}{c}\text { Cabri et. al. } \\
\text { (1984) }\end{array}$} & f & 29.70 & 0.12 & 36.60 & 34.00 & & & & 0,02 & & & & & & & 97.44 \\
\hline
\end{tabular}

$\mathrm{a}, \mathrm{b}=$ electron microprobe

$\mathrm{c}=$ electron microprobe, Mina Western Canada $\mathrm{Cu}_{1,01} \mathrm{Fe}_{1,01} \mathrm{~S}_{2,00}$

$\mathrm{d}=\mathrm{CuFeS}_{2}$

e = análise quimica (Res: resíduo de ácido insolúvel porignition principalmente homeblenda)

$\mathrm{f}=$ electron microprobe

\begin{tabular}{|c|c|c|c|c|c|c|c|c|c|c|c|c|c|c|c|}
\hline \multirow{2}{*}{ Perfil } & \multirow{2}{*}{$\begin{array}{l}\text { Código } \\
\text { da } \\
\text { amostra }\end{array}$} & \multirow{2}{*}{$\begin{array}{l}\text { Tipo de } \\
\text { alteração }\end{array}$} & \multicolumn{13}{|c|}{ Cátions calculados para $2 \mathrm{~S}$} \\
\hline & & & $\mathrm{Fe}$ & $\mathrm{Ni}$ & $\mathrm{Cu}$ & $\mathrm{s}$ & $\mathrm{Mg}$ & $\mathrm{Zn}$ & $\mathrm{Ca}$ & Co & $\mathrm{Ag}$ & As & $\mathrm{Au}$ & $\mathrm{Mn}$ & $\mathrm{Si}$ \\
\hline $\mathrm{S}-1$ & $D-5(7)$ & $\mathrm{K}-\mathrm{P}$ & 1.002 & ---- & 0.970 & 2.000 & ---- & ---- & ---- & ---- & ---- & ----- & 0.001 & ---- & ---- \\
\hline $\mathrm{S}-1$ & $\mathrm{D}-5(8)$ & K-P & 1.027 & ---- & 0.976 & 2.000 & ---- & ---- & ---- & ----- & 0.000 & ---- & 0.001 & ---- & ---- \\
\hline S-1 & $D-5(9)$ & K-P & 1.009 & ---- & 0.947 & 2.000 & ---- & 0.002 & ---- & ---- & 0.001 & ---- & ---- & ---- & ---- \\
\hline $\mathrm{S}-3$ & $Q-3(4)$ & $\mathrm{K}-\mathrm{P}$ & 1.004 & ---- & 0.956 & 2.000 & ---- & 0.002 & ---- & ---- & ---- & ---- & ---- & ---- & ---- \\
\hline $\mathrm{S}-3$ & $\mathrm{M}-5(9)$ & $\mathrm{P}-\mathrm{K}$ & 1.001 & ---- & 0.960 & 2.000 & ---- & ---- & 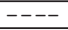 & ---- & $\overline{-----}$ & ---- & ---- & ---- & ---- \\
\hline $\mathrm{S}-3$ & $M-5(6)$ & $\mathrm{P}-\mathrm{K}$ & 0.995 & ---- & 0.961 & 2.000 & ---- & ---- & ---- & ---- & ---- & ---- & ---- & ---- & ---- \\
\hline $\mathrm{S}-3$ & $M-5(7)$ & $\mathrm{P}-\mathrm{K}$ & 0.990 & ---- & 0.953 & 2.000 & ---- & ---- & ---- & ----- & ---- & ---- & ---- & ---- & ---- \\
\hline S-1 & $\mathrm{F}-1(1)$ & $K(i)=P-F$ & \begin{tabular}{|l|}
0.977 \\
\end{tabular} & ----- & 0.968 & 2.000 & ----- & ---- & ---- & ----- & ---- & ----- & 0.001 & ---- & ---- \\
\hline S-1 & $F-1(4)$ & $K(i)=P-F$ & 1.003 & ---- & 0.987 & 2.000 & ---- & ---- & ---- & $\mid----$ & ---- & ---- & ---- & ---- & ---- \\
\hline S-1 & $\mathrm{F}-1(7)$ & $K(i)=P-F$ & 1.008 & ---- & 0.975 & 2.000 & ---- & ---- & ---- & ---- & ---- & ---- & ---- & ---- & ---- \\
\hline S-2 & $J-4(7)$ & F-P & \begin{tabular}{|l|}
1.009 \\
\end{tabular} & ---- & 0.943 & 2.000 & ---- & 0.003 & ---- & ---- & ---- & ---- & 0.003 & ---- & ---- \\
\hline S-3 & $J-4(8)$ & F-P & \begin{tabular}{|l|}
1.017 \\
\end{tabular} & ---- & 0.947 & 2.000 & ---- & ---- & ---- & ----- & ---- & ----- & ----- & ---- & ---- \\
\hline
\end{tabular}

da potassica-propílica/filica.

\section{Pirrotita $\left(\mathrm{Fe}_{1-x} \mathrm{~S}\right)$ :}

Foram obtidas três análises para pirrotita, correspondentes a três amostras que apresentavam inclusões com associação entre calcopirita e pirrotita. Os resultados, para amostras das zonas de alteração fílica-propílica (amostra J-4), potássica-propílica/fílica (amostras F-1) e propílicapotássica (amostra M-5) são apresentados na Tabela 7.5.

Os resultados mostram composições relativamente puras, com teores em Cu variáveis entre ca. 0,40 e 1,50\% em peso. Ente os elementos traços, apenas Zn, presente significativamente em todas as análises e Au, presente na amostra representativa da zona fílica-propílica merecem destaque. Ni aparece em uma análise com valor muito próximo ao limite de detecção ( $c a$. 
Tabela 7.4: (A) Análises químicas pontuais (WDS) para inclusões de cubanita (bd = abaixo do limite de deteç̧ão). Análises de cubanitas da literatura: (a) rocha hospedeira não descrita, mina Barracanao, Cuba (análises químicas convencionais), (b) para $\mathrm{CuFe}_{2} \mathrm{~S}_{3}$ (análises químicas convencionais), (c) rocha hospedeira não descrita, mina Ohmine, Iwate Japan (análises químicas convencionais) e (d,e) em cubanitas de meteoritos (análises WDS). (B) Fórmula estrutural.

\begin{tabular}{|c|c|c|c|c|c|c|c|c|c|c|c|c|c|c|c|c|c|c|}
\hline Perfil & $\begin{array}{l}\text { Código } \\
\text { da } \\
\text { amostra }\end{array}$ & $\begin{array}{c}\text { Tipo de } \\
\text { alteração }\end{array}$ & $\mathrm{Fe}$ & $\mathrm{Ni}$ & $\mathrm{Cu}$ & $\mathrm{s}$ & $\mathrm{Mg}$ & $\mathrm{Zn}$ & $\mathrm{Ca}$ & Co & $\mathrm{Ag}$ & As & $\mathrm{Au}$ & $\mathrm{Mn}$ & $\mathrm{Si}$ & $\begin{array}{c}\text { Res. (ácido } \\
\text { insolúvel } \\
\text { resíduo) }\end{array}$ & $\mathrm{H}_{2} \mathrm{O}$ & Total \\
\hline S-3 & $\mathrm{Q}-3(1)$ & K-P & 39.41 & $\mathrm{bd}$ & 22.76 & 35.03 & $\mathrm{bd}$ & $\mathrm{bd}$ & $\mathrm{bd}$ & $\mathrm{bd}$ & $\mathrm{bd}$ & $\mathrm{bd}$ & $b d$ & $b d$ & 0.05 & & & 97.28 \\
\hline S-3 & $Q-3(2)$ & K-P & 37.48 & $\mathrm{bd}$ & 24.74 & 35.11 & $\mathrm{bd}$ & 0.30 & $\mathrm{bd}$ & $\mathrm{bd}$ & $b d$ & $\mathrm{bd}$ & $b d$ & $\mathrm{bd}$ & $\mathrm{bd}$ & & & 97.66 \\
\hline $\mathrm{S}-3$ & Q-3 (3) & K-P & 39.43 & $\mathrm{bd}$ & 23.36 & 34.62 & $\mathrm{bd}$ & $\mathrm{bd}$ & $\mathrm{bd}$ & $\mathrm{bd}$ & 0.03 & $\mathrm{bd}$ & bd & $b d$ & $\mathrm{bd}$ & & & 97.45 \\
\hline S-3 & $M-5(3)$ & P-K & 40.02 & 0.03 & 22.71 & 34.73 & $\mathrm{bd}$ & $b d$ & $b d$ & $b d$ & $b d$ & $\mathrm{bd}$ & $b d$ & $b d$ & $b d$ & & & 97.50 \\
\hline S-3 & $M-5(4)$ & P-K & 39.76 & $\mathrm{bd}$ & 22.85 & 35.31 & $\mathrm{bd}$ & $\mathrm{bd}$ & $\mathrm{bd}$ & $\mathrm{bd}$ & 0.07 & $\mathrm{bd}$ & $b d$ & $\mathrm{bd}$ & $\mathrm{bd}$ & & & 98.04 \\
\hline S-1 & $F-1(6)$ & $K(i)=P-F$ & 40.21 & $\mathrm{bd}$ & 22.89 & 34.35 & $\mathrm{bd}$ & $\mathrm{bd}$ & $\mathrm{bd}$ & bd & bd & $\mathrm{bd}$ & $b d$ & $\mathrm{bd}$ & $\mathrm{bd}$ & & & 97.50 \\
\hline $\mathrm{S}-2$ & $J-4(3)$ & F-P & 40.89 & $\mathrm{bd}$ & 22.59 & 35.71 & $\mathrm{bd}$ & $\mathrm{bd}$ & $\mathrm{bd}$ & $\mathrm{bd}$ & $\mathrm{bd}$ & $\mathrm{bd}$ & 0.21 & $\mathrm{bd}$ & $\mathrm{bd}$ & & & 99.46 \\
\hline $\mathrm{S}-2$ & $J-4(4)$ & F-P & 40.11 & $\mathrm{bd}$ & 22.74 & 35.63 & $\mathrm{bd}$ & 0.10 & $b d$ & bd & bd & $\mathrm{bd}$ & 0.30 & $\mathrm{bd}$ & $\mathrm{bd}$ & & & 98.91 \\
\hline S-2 & $J-4(5)$ & F-P & 40.99 & $\mathrm{bd}$ & 22.88 & 35.58 & $b d$ & $\mathrm{bd}$ & $\mathrm{bd}$ & $\mathrm{bd}$ & $\mathrm{bd}$ & $\mathrm{bd}$ & 0.27 & bd & $\mathrm{bd}$ & & & 99.76 \\
\hline $\mathrm{S}-2$ & $J-4(6)$ & F-P & 40.43 & 0.03 & 22.85 & 35.46 & $\mathrm{bd}$ & $\mathrm{bd}$ & $\mathrm{bd}$ & $\mathrm{bd}$ & 0.03 & $\mathrm{bd}$ & 0.16 & $\mathrm{bd}$ & $\mathrm{bd}$ & & & 98.99 \\
\hline \multirow{2}{*}{\multicolumn{2}{|c|}{$\begin{array}{c}\text { Macdougall \& } \\
\text { Ferridge (1977) }\end{array}$}} & d & 40.70 & & 23.90 & 35.50 & & & & & & & & & & & & 100.10 \\
\hline & & $\mathrm{e}$ & 40.60 & & 23.30 & 36.90 & & & & & & & & & & & & 100.80 \\
\hline
\end{tabular}

$a=$ chemistry: Barracanao Cuba

$\mathrm{c}=$ análise quimica (Res: resíduo de ácido insolúvel por ignition principalmente horneblenda)

$\mathrm{d}=$ electron microprobe

$\mathrm{e}=$ electron microprobe

(B)
\begin{tabular}{|c|c|c|c|c|c|c|c|c|c|c|c|c|c|c|c|}
\hline Perfil & $\begin{array}{c}\text { Código } \\
\text { da } \\
\text { amostra }\end{array}$ & $\begin{array}{c}\text { Tipo de } \\
\text { alteração }\end{array}$ & $\mathrm{Fe}$ & $\mathrm{Ni}$ & $\mathrm{Cu}$ & $\mathrm{S}$ & $\mathrm{Mg}$ & $\mathrm{Zn}$ & $\mathrm{Ca}$ & $\mathrm{Co}$ & $\mathrm{Ag}$ & $\mathrm{As}$ & $\mathrm{Au}$ & $\mathrm{Mn}$ & $\mathrm{Si}$ \\
\hline S-3 & Q-3 (1) & K-P & 1.938 & ---- & 0.983 & 3.000 & ---- & ---- & ---- & ---- & ---- & ---- & ---- & ----- & 0.005 \\
\hline S-3 & Q-3 (2) & K-P & 1.838 & ---- & 1.066 & 3.000 & ---- & 0.012 & ---- & ---- & ---- & ---- & ---- & ----- & ----- \\
\hline S-3 & Q-3 (3) & K-P & 1.961 & ---- & 1.021 & 3.000 & ---- & ---- & ---- & ---- & 0.001 & ---- & ---- & ---- & ---- \\
\hline S-3 & M-5(1) & P-K & 1.958 & ---- & 0.992 & 3.000 & ---- & 0.004 & ---- & ---- & 0.002 & ---- & ---- & ---- & ---- \\
\hline S-3 & M-5(2) & P-K & 1.942 & ---- & 0.960 & 3.000 & ---- & 0.008 & ---- & ---- & ---- & ---- & ---- & ---- & ---- \\
\hline S-3 & M-5(3) & P-K & 1.985 & 0.001 & 0.990 & 3.000 & ---- & ---- & ---- & ---- & ---- & ---- & ---- & ---- & ---- \\
\hline S-3 & M-5(4) & P-K & 1.939 & ---- & 0.979 & 3.000 & ---- & ---- & ---- & ---- & 0.002 & ---- & ---- & ---- & ---- \\
\hline S-1 & F-1(6) & K(i)=P-F & 2.016 & ---- & 1.009 & 3.000 & ---- & ---- & ----- & ---- & ---- & ---- & ---- & ----- & ---- \\
\hline S-2 & J-4(3) & F-P & 1.972 & ---- & 0.958 & 3.000 & ---- & ----- & ---- & ---- & ---- & ---- & 0.003 & ----- & ---- \\
\hline S-2 & J-4(4) & F-P & 1.939 & ---- & 0.966 & 3.000 & ---- & 0.004 & ----- & ---- & ---- & ---- & 0.004 & ----- & ---- \\
\hline S-2 & J-4(5) & F-P & 1.984 & ---- & 0.974 & 3.000 & ---- & ----- & ----- & ---- & ---- & ---- & 0.004 & ----- & ---- \\
\hline S-2 & J-4(6) & F-P & 1.964 & 0.001 & 0.975 & 3.000 & ----- & ----- & ---- & ---- & 0.001 & ---- & 0.002 & ---- & ---- \\
\hline
\end{tabular}

0,03\%). Estes resultados são significativamente diferentes dos apresentados por Gomez \& Fabas (2006) para pirrotida presente em granito de muscovita associada a mineralização de $\mathrm{Sn}$, que reportam quantidades sistematicamente maiores de $\mathrm{Cu}, \mathrm{Zn}$, bem como quantidades significativas de As e Mn. Cabri et al. (1984) reporta alem de Fe e S quantidades significativas de $\mathrm{Ni}$ e $\mathrm{Co}$ em rochas de complexos máficos estratiformes de jazidas de sulfetos de $\mathrm{Cu}$ e $\mathrm{Ni}$.

\section{Mackinawita $\left(\mathrm{Fe}_{1+x} \mathrm{~S}\right)$ :}

A mackinawita é um mineral que se revelou de análise extremamente difícil, devido ocorrer nos intercrescimentos (tipo cp/mck:4f, 1b, 1e, 3c) de modo geral vermiforme, à oxidação superficial muito rápida (e.g. Schouten, 1962; Uytenbogaardt, 1971) e as dimensões diminutas com que aparece. Não obstante foram obtidas quatro análises pontuais representativas de boa qualidade (Tabela 7.6), três da quais correspondem à zona de alteração potássica-propílica (amostra D-5) e uma da zona propílica-potássica (amostra B-1). 
Tabela 7.5: (A). Análises químicas pontuais (WDS) para inclusões de pirrotita (bd = abaixo do limite de detecção). Análises de pirrotitas da literatura: (a) em rocha hospedeira de granito de muscovita associada à mineralização de Sn, mina Ervedosa - Portugal (análises WDS), (b,c) em piroxenitaperidotita serpentinizada (análises WDS), (d) rocha hospedeira não descrita, mina Homestake, de $\mathrm{Pb}$, Lawrence Co. South Dakota, EE.UU. Fe:S=0.87 (análises químicas convencionais) e (e) em rochas de complexos máficos estratiformes, jazidas de sulfetos de Cu-Ni, Sudbury - Canada (análises químicas convencionais). (B) Fórmula estrutural.

\begin{tabular}{|c|c|c|c|c|c|c|c|c|c|c|c|c|c|c|c|c|}
\hline \multirow{2}{*}{ Perfil } & \multirow{2}{*}{$\begin{array}{c}\text { Código } \\
\text { da } \\
\text { amostra }\end{array}$} & \multirow{2}{*}{$\begin{array}{c}\text { Tipo de } \\
\text { alteração }\end{array}$} & \multicolumn{13}{|c|}{ Elementos analisados (\% peso) } & \multirow[b]{2}{*}{ Total } \\
\hline & & & $\mathrm{Fe}$ & $\mathrm{Ni}$ & $\mathrm{Cu}$ & $\mathrm{s}$ & $\mathrm{Mg}$ & $\mathrm{Zn}$ & $\mathrm{Ca}$ & Co & $\mathrm{Ag}$ & As & $\mathrm{Au}$ & $\mathrm{Mn}$ & $\mathrm{Si}$ & \\
\hline $\mathrm{S}-3$ & $M-5(5)$ & $\mathrm{P}-\mathrm{K}$ & 58.80 & 0.03 & 0.78 & 37.29 & 0.00 & 0.08 & $\mathrm{bd}$ & $\mathrm{bd}$ & $\mathrm{bd}$ & $\mathrm{bd}$ & bd & $\mathrm{bd}$ & $\mathrm{bd}$ & 97.00 \\
\hline $\mathrm{S}-2$ & $\mathrm{~J}-4(1)$ & F-P & 60.62 & $\mathrm{bd}$ & 0.45 & 40.01 & 0.00 & 0.08 & $\mathrm{bd}$ & $\mathrm{bd}$ & $\mathrm{bd}$ & $\mathrm{bd}$ & 0.30 & $\mathrm{bd}$ & $\mathrm{bd}$ & 101.48 \\
\hline S-2 & $\mathrm{J}-4(2)$ & F-P & 60.42 & $\mathrm{bd}$ & 0.38 & 38.38 & 0.00 & 0.05 & $\mathrm{bd}$ & bd & $\mathrm{bd}$ & bd & $\mathrm{bd}$ & $\mathrm{bd}$ & $\mathrm{bd}$ & 99.25 \\
\hline \multirow{2}{*}{\multicolumn{2}{|c|}{ Meldrum (1998) }} & $b$ & 60.17 & & & 39.62 & & & & & & & & & & 99.78 \\
\hline & & c & 60.24 & & & 39.79 & & & & & & & & & & 100.30 \\
\hline \multicolumn{2}{|c|}{$\begin{array}{c}\text { Anthony et. al. } \\
(1990)\end{array}$} & $d$ & 60.18 & & & 39.82 & & & & & & & & & & 100.0 \\
\hline \multicolumn{2}{|c|}{$\begin{array}{c}\text { Cabri et. al } \\
(1984)\end{array}$} & e & 56.00 & 1.14 & 0.15 & 34.4 & & & & 0.02 & & & & & & 91.71 \\
\hline
\end{tabular}

a = Cámeca Camebax electron microprobe

$\mathrm{b}, \mathrm{c}=$ electron microprobe

$\mathrm{d}=$ chemistry Homestake mine lead USA. Fe:S $=0,87$

$\mathrm{e}=$ assay of concentrate

(B)
\begin{tabular}{|c|c|c|c|c|c|c|c|c|c|c|c|c|c|c|c|}
\hline Perfil & $\begin{array}{c}\text { Código } \\
\text { da } \\
\text { amostra }\end{array}$ & $\begin{array}{c}\text { Tipo de } \\
\text { alteração }\end{array}$ & $\mathrm{Fe}$ & $\mathrm{Ni}$ & $\mathrm{Cu}$ & $\mathrm{S}$ & $\mathrm{Mg}$ & $\mathrm{Zn}$ & $\mathrm{Ca}$ & $\mathrm{Co}$ & $\mathrm{Ag}$ & $\mathrm{As}$ & $\mathrm{Au}$ & $\mathrm{Mn}$ & $\mathrm{Si}$ \\
\hline $\mathrm{S}-1$ & $\mathrm{~F}-1(5)$ & $\mathrm{K}(\mathrm{i})=\mathrm{P}-\mathrm{F}$ & 0.916 & ---- & 0.021 & 1.000 & ---- & 0.001 & ---- & ---- & ---- & ---- & ---- & ---- & ---- \\
\hline S-3 & $\mathrm{M}-5(5)$ & $\mathrm{P}-\mathrm{K}$ & 0.905 & 0.000 & 0.011 & 1.000 & ---- & 0.001 & ---- & ---- & ---- & ---- & ---- & ---- & ---- \\
\hline S-2 & $\mathrm{J}-4(1)$ & $\mathrm{F}-\mathrm{P}$ & 0.870 & ---- & 0.006 & 1.000 & ---- & 0.001 & ---- & ---- & ---- & ---- & 0.001 & ---- & ---- \\
\hline S-2 & $\mathrm{J}-4(2)$ & $\mathrm{F}-\mathrm{P}$ & 0.904 & ---- & 0.005 & 1.000 & ---- & 0.001 & ---- & ---- & ---- & ---- & ---- & ---- & ---- \\
\hline
\end{tabular}

As análises revelam quantidades significativas de $\mathrm{Cu}(0,14-8,6 \%$ em peso), Zn $(0,13 ; 0,33$ $\%$ em peso) e Au (0,10-0,13 \% em peso). Abundâncias em níveis de traço são verificadas em geral para Ni e Ag. Estes dados confirmam o fato de que embora Ni e Co sejam elementos típicos neste mineral, existem casos em que ambos encontram-se próximos ou abaixo do limite de detecção (Krupp, 1994; Kouvo \& Vuorelainen, 1963). 
Tabela 7.6: (A). Análises químicas pontuais (WDS) para inclusões de mackinawita (bd = abaixo do limite de detecção). Análises de mackinawitas da literatura: (a,b) em andesitos alterados hidrotermalmente (kaolinitização), jazida de Hg, mina Moschellandsberg - SW Alemanha (análises WDS), $(c, d)$ em mina de cobre Chadmari, Rajasthan - India (análises WDS), (e) em calcopirita de serpentinita, mina de Ni, Outokumpo - Finlândia (análises WDS) e (f) em mina de Cu, Ni, Au, Mackinaw, Washington - EEUU (análises WDS). (B) fórmula estrutural.

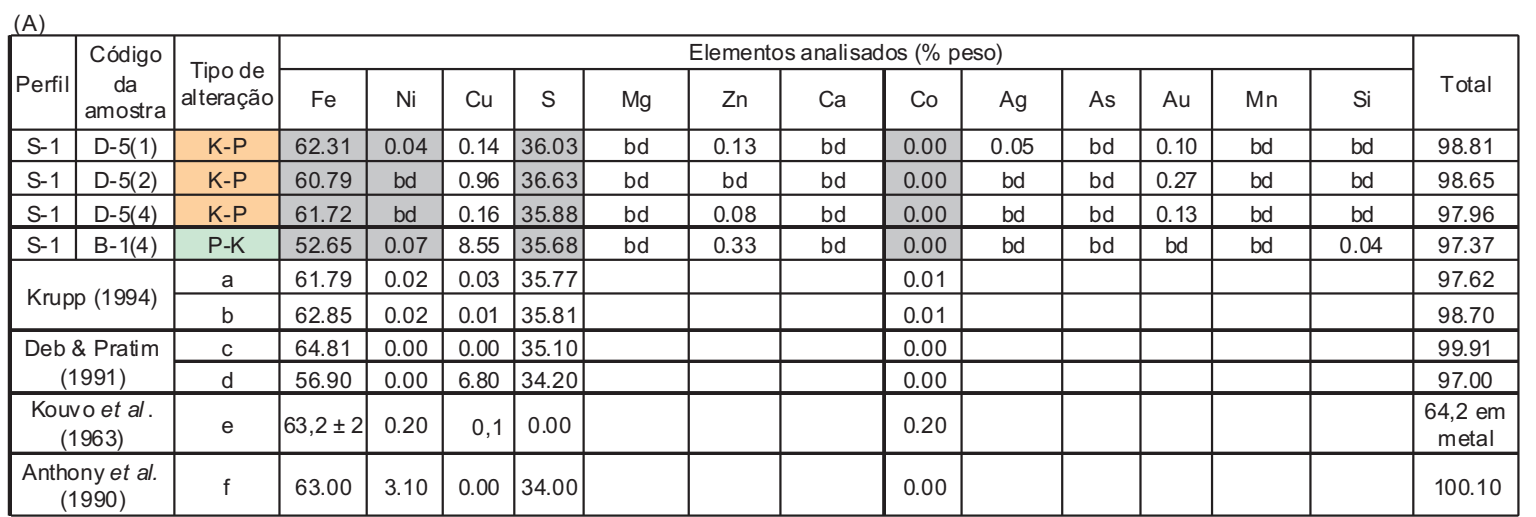

$\mathrm{a}, \mathrm{b}=$ Camebax microbeam probe

$\mathrm{c}, \mathrm{d}=$ electron microprobe, Ylojarvi, Finland

$\mathrm{e}=$ electron - probe

$f=$ electron microprobe, corresponding to $\mathrm{Fe}_{1,06} \mathrm{Ni}_{0,05} \mathrm{~S}$ or $(\mathrm{FeNi})_{9} \mathrm{~S}_{8}$, Mackinaw mine USA

(B)
\begin{tabular}{|c|c|c|c|c|c|c|c|c|c|c|c|c|c|c|c|}
\hline Perfil & $\begin{array}{c}\text { Código } \\
\text { da } \\
\text { amostra }\end{array}$ & $\begin{array}{c}\text { Tipo de } \\
\text { alteração }\end{array}$ & $\mathrm{Fe}$ & $\mathrm{Ni}$ & $\mathrm{Cu}$ & $\mathrm{S}$ & $\mathrm{Mg}$ & $\mathrm{Zn}$ & $\mathrm{Ca}$ & $\mathrm{Co}$ & $\mathrm{Ag}$ & $\mathrm{As}$ & $\mathrm{Au}$ & $\mathrm{Mn}$ & $\mathrm{Si}$ \\
\hline S-1 & $\mathrm{D}-5(1)$ & $\mathrm{K}-\mathrm{P}$ & 0.993 & 0.001 & 0.002 & 1.000 & ---- & 0.002 & ---- & ---- & 0.000 & ---- & 0.000 & ---- & ---- \\
\hline S-1 & $\mathrm{D}-5(2)$ & $\mathrm{K}-\mathrm{P}$ & 0.953 & ---- & 0.013 & 1.000 & ---- & ---- & ---- & ---- & ---- & ---- & 0.001 & ---- & ---- \\
\hline S-1 & $\mathrm{D}-5(4)$ & $\mathrm{K}-\mathrm{P}$ & 0.987 & ---- & 0.002 & 1.000 & ---- & 0.001 & ---- & ---- & ---- & ---- & 0.001 & ---- & ---- \\
\hline $\mathrm{S}-1$ & $\mathrm{~B}-1(4)$ & $\mathrm{P}-\mathrm{K}$ & 0.847 & 0.001 & 0.121 & 1.000 & ---- & 0.005 & ---- & ---- & ---- & ---- & ---- & ---- & 0.001 \\
\hline
\end{tabular}

\subsection{Freqüências e distribuição estatística das inclusões e inter- crescimentos}

Os trabalhos ao microscópio mostraram que, dentre as 77 amostras consideradas, 55 apresentam alguma destas inclusões, ou seja, cerca de $71 \%$. Na descrição da freqüência relativa destas fases minerais nos intercrescimentos foram utilizados os termos traço, escasso, pouco freqüente, freqüente e muito freqüente, que se referem a intervalos numéricos definidos por simplicidade com base no número máximo contado de inclusões de um mineral que foi de 61 . Os cinco intervalos definidos $(61 / 5)$ na escala empregada são apresentados na Tabela 7.7.

Assim, de um total de 824 inclusões computadas, nas quais se fizeram 1601 contagens da ocorrência dos minerais de pirrotita, cubanita, mackinawita e calcopirita tem-se que a fase mais freqüente corresponde à calcopirita $(43,4 \%)$, seguida de pirrotita $(32,5 \%)$, mackinawita $(18,9$ $\%)$ e cubanita, que é a fase menos freqüente $(5,2 \%)$. Os resultados obtidos são sumarizados na Tabela 7.8 .

De acordo com a sua freqüência, os intercrescimentos muito freqüentes-simples são de py/po:1e (15,7\%), cp/mck:4f (15,2\%) e cp/po:1b (14.8\%). Os freqüentes-simples são cp/mck: 1b (7.0\%), cp/mck:1e (4.6\%), cp/po:1a (5,3\%), po/cp: 1a(5.7\%), po/cp:1b (4.9\%) e os in- 
Tabela 7.7: Divisão arbitrária de categorias para mostrar as freqüências dos minerais que constituem os intercrescimentos.

\begin{tabular}{|l|l|l|}
\hline Categoria & \multicolumn{2}{|c|}{ Valor } \\
\hline Traço & T & $0-12$ \\
\hline Escasso & E & $12-24$ \\
\hline Pouco freqüente & M & $24-36$ \\
\hline Freqüente & F & $36-48$ \\
\hline Muito freqüente & A & $48-61$ \\
\hline
\end{tabular}

tercrescimentos pouco freqüentes-simples são cp/mck:3b $(2,1 \%), \mathrm{cp} / \mathrm{mck}: 3 \mathrm{c}(1,7 \%), \mathrm{cp} / \mathrm{cb}: 1 \mathrm{a}$ $(0,8 \%), \mathrm{cp} / \mathrm{cb}: 3 \mathrm{a}(1,5 \%)$. Os intercrescimentos complexos são todos pouco freqüentes: (cp/po:1b)/mck:1b (1,0\%), (cp/cb:3a)/po:1e (1,0\%), (cp/po:1b)/mck:1e (0.8\%) e (cp/po:1b)/cb:3a $(1,8 \%)$. Na Figura 7.4 ilustra-se para comparação a porcentagem relativa destes intercrescimentos.

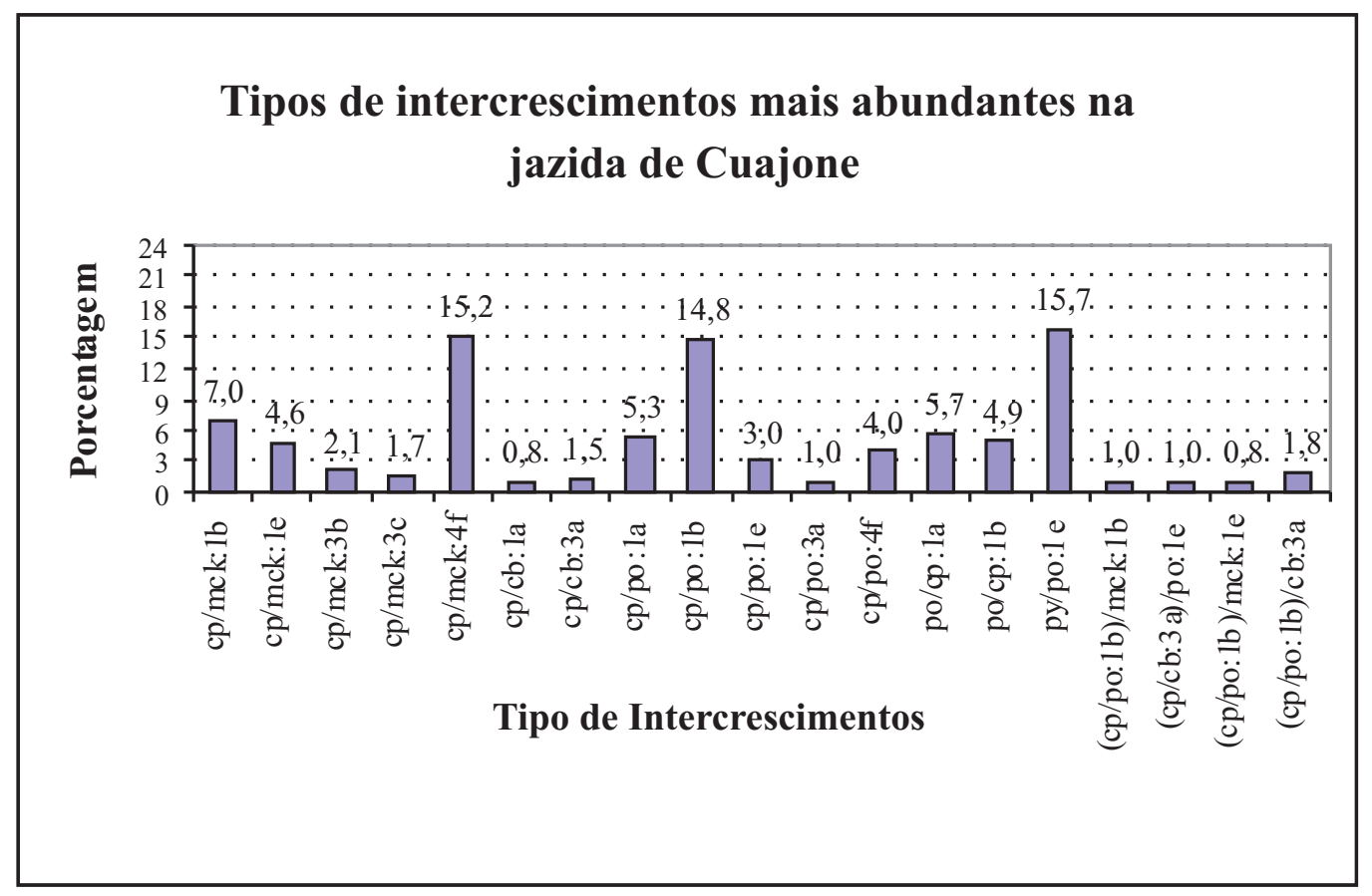

Figura 7.4: Porcentagem relativa dos diferentes tipos de intercrescimentos mais freqüentes na Jazida Cuajone. 
TABELA 7.8 Freqüência e distribuicão estatistica das inclusões e intercresciment

\begin{tabular}{|c|c|c|c|c|c|c|c|c|c|c|c|c|}
\hline \multirow[t]{2}{*}{ No } & \multirow[t]{2}{*}{$\begin{array}{l}\text { Código das } \\
\text { amostras }\end{array}$} & \begin{tabular}{|c|}
$\mathrm{N}^{\circ}$ total de \\
inclusões/interc \\
rescimentos
\end{tabular} & $\begin{array}{r}\text { Núm } \\
\text { i }\end{array}$ & $\begin{array}{r}\text { ro de } \\
\text { forn } \\
\text { tercre }\end{array}$ & $\begin{array}{l}\text { inera } \\
\text { m os } \\
\text { iment }\end{array}$ & $\begin{array}{l}\text { s que } \\
\text { s }\end{array}$ & $\begin{array}{c}\mathbf{N}^{\circ} \text { total de minerais que } \\
\text { formam os } \\
\text { intercrescimentos }\end{array}$ & $\begin{array}{l}\text { Freqü } \\
\text { forma }\end{array}$ & $\begin{array}{c}\text { ência } \\
\text { m os i } \\
\text { nas }\end{array}$ & $\begin{array}{l}\text { dos mi } \\
\text { tercre } \\
\text { nclusõ }\end{array}$ & $\begin{array}{l}\text { ais que } \\
\text { mentos }\end{array}$ & Outros Minerais \\
\hline & & & mck & cb & po & $\mathbf{c p}$ & & mck & $\mathbf{c b}$ & po & $\mathbf{c p}$ & \\
\hline 1 & E-3 & 2 & & & 2 & 1 & 3 & - & - & $\mathrm{T}$ & $\mathrm{T}$ & $\mathrm{mg}^{+}, \pm \mathrm{py} \cong \mathrm{cp} \pm \mathrm{hm}=$ \\
\hline 2 & H-1 & 7 & 2 & & 5 & 5 & 12 & $\mathrm{~T}$ & - & $\mathrm{T}$ & $\mathrm{T}$ & $\mathrm{mb}, \mathrm{py} \cong \mathrm{cp}$, bor- cv-,rt-, mg", hm” $=\mathrm{ef}^{=}$(?), arsenopirita (?) \\
\hline 3 & B-3 & & & & & & & - & - & - & - & $\mathrm{mg}^{+}, \pm \mathrm{py} \geq \mathrm{cp}$, bor $^{=}$ \\
\hline 4 & $C-4$ & & & & & & & - & - & - & - & $\mathrm{cp}, \mathrm{mb}, \mathrm{mg}, \mathrm{cp}, \pm$ bor, $\mathrm{cv}=, \mathrm{py}=$ \\
\hline 5 & Q-3 & 39 & 16 & 3 & 24 & 28 & 71 & E & $\mathrm{T}$ & $\mathrm{E} / \mathrm{M}$ & M & $\mathrm{mb}, \mathrm{py}>\mathrm{cp}$ \\
\hline 6 & D-5 & 41 & 11 & 6 & 29 & 26 & 72 & $\mathrm{~T} / \mathrm{E}$ & $\mathrm{T}$ & $\mathrm{M}$ & M & $\mathrm{py} \cong \mathrm{cp}, \mathrm{mg}$ \\
\hline 7 & $\mathrm{~F}-2$ & 35 & 3 & 8 & 32 & 30 & 73 & $\mathrm{~T}$ & $\mathrm{~T}$ & $\mathrm{M}$ & $\mathrm{M}$ & py > cp, \pm rt-LCX, mge $\mathrm{hm}^{-}$ \\
\hline 8 & $\mathrm{~F}-3$ & 29 & 7 & & 26 & 14 & 47 & $\mathrm{~T}$ & - & $\mathrm{M}$ & E & py, mg, rt-LCX \pm hm, \pm cp', bor', cv- \\
\hline 9 & $\mathrm{E}-2$ & 3 & 1 & & 2 & 2 & 5 & $\mathrm{~T}$ & - & $\mathrm{T}$ & $\mathrm{T}$ & $\mathrm{mg}^{+}, \pm \mathrm{cp} \geq \mathrm{py}, \mathrm{po}^{=}$ \\
\hline 10 & D-6 & 11 & 5 & & 6 & 8 & 19 & $\mathrm{~T}$ & - & $\mathrm{T}$ & $\mathrm{T}$ & $\mathrm{mg}, \mathrm{rt}-\mathrm{LCX}, \mathrm{py} \cong \mathrm{cp}$ \\
\hline 11 & $\mathrm{C}-3$ & 2 & 1 & 1 & & 2 & 4 & $\mathrm{~T}$ & $\mathrm{~T}$ & - & $\mathrm{T}$ & $m g, c p \cong p y, e^{=}$ \\
\hline 12 & $\mathrm{O}-3$ & 2 & 2 & & & 2 & 4 & $\mathrm{~T}$ & - & - & $\mathrm{T}$ & $\mathrm{cp}^{+}>\mathrm{py}, \mathrm{rt}, \mathrm{mb}$ \\
\hline 13 & D-4 & & & & & & & - & - & - & - & $\mathrm{py}^{-}>\mathrm{cp}^{-} \pm \mathrm{mg}, \mathrm{rt}, \mathrm{LCX}$ \\
\hline 14 & D-3 & & & & & & & - & - & - & - & $\mathrm{cp}^{+}>\mathrm{py}^{-}, \mathrm{LCX}$ \\
\hline 15 & $\mathrm{~V}-1$ & 53 & 15 & 1 & 37 & 41 & 94 & E & $\mathrm{T}$ & $\mathrm{F} / \mathrm{M}$ & $\mathrm{F}$ & $\mathrm{py}^{+}>\mathrm{cp}, \mathrm{mg} \pm \mathrm{rt}-\mathrm{LCX}, \mathrm{hm}$ \\
\hline 16 & $\mathrm{~N}-3$ & 24 & 17 & 1 & 8 & 19 & 45 & E & $\mathrm{T}$ & $\mathrm{T}$ & E & $\mathrm{py}>\mathrm{cp}= \pm \mathrm{mg}$ \\
\hline 17 & M-5 & 44 & 11 & 4 & 32 & 35 & 82 & $\mathrm{~T} / \mathrm{E}$ & $\mathrm{T}$ & M & $\mathrm{M} / \mathrm{F}$ & $\mathrm{py}^{+} \pm \mathrm{mg}$ \\
\hline 18 & B-1 & 14 & 2 & 2 & 11 & 14 & 29 & $\mathrm{~T}$ & $\mathrm{~T}$ & $\mathrm{~T} / \mathrm{E}$ & $\mathrm{E}$ & $\mathrm{mg}^{+}, \mathrm{py}, \mathrm{cp} \pm \mathrm{mg}-\mathrm{hm}, \mathrm{rt}$ \\
\hline 19 & $\mathrm{~V}-3$ & 27 & 2 & 1 & 24 & 18 & 45 & $\mathrm{~T}$ & $\mathrm{~T}$ & $\mathrm{E} / \mathrm{M}$ & $\mathrm{E}$ & py > cp, mg \\
\hline 20 & P-3 & 18 & 8 & & 10 & 14 & 32 & $\mathrm{~T}$ & - & $\mathrm{T} / \mathrm{E}$ & E & py $>$ cp $\pm \mathrm{rt} \pm \mathrm{mg}$ \\
\hline 21 & $\mathrm{H}-2$ & 5 & 2 & & 3 & 3 & 8 & $\mathrm{~T}$ & - & $\mathrm{T}$ & $\mathrm{T}$ & $\mathrm{mg}^{+}, \mathrm{hm} \pm \mathrm{py}, \mathrm{cp}, \mathrm{cv}$, bor, arsenopirita (? \\
\hline 22 & E-1 & 9 & 3 & & 6 & 8 & 17 & $\mathrm{~T}$ & - & $\mathrm{T}$ & $\mathrm{T}$ & $\mathrm{cp} \geq \mathrm{py}, \mathrm{mg}, \mathrm{mb}$ \\
\hline 23 & $\mathrm{~T}-2$ & 4 & 3 & & 2 & 4 & 9 & $\mathrm{~T}$ & - & $\mathrm{T}$ & $\mathrm{T}$ & $\mathrm{cp}>\mathrm{py}, \mathrm{mb} \pm \mathrm{rt}$ \\
\hline 24 & $\mathrm{~S}-1$ & 6 & 3 & & 3 & 6 & 12 & $\mathrm{~T}$ & - & $\mathrm{T}$ & $\mathrm{T}$ & $\mathrm{cp}>\mathrm{py} \pm \mathrm{rt}-\mathrm{LCX}, \mathrm{mb}$ \\
\hline 25 & K-3 & 6 & 4 & & 2 & 6 & 12 & $\mathrm{~T}$ & - & $\mathrm{T}$ & $\mathrm{T}$ & py $>$ cp, mg, rt-LCX \pm hm \\
\hline 26 & $\mathrm{~V}-2$ & 7 & 7 & & & 7 & 14 & $\mathrm{~T}$ & - & - & $\mathrm{T}$ & py $>\mathrm{cp}^{2}, \mathrm{mg}$ \\
\hline 27 & $\mathrm{R}-3$ & 1 & 1 & & & 1 & 2 & $\mathrm{~T}$ & - & - & $\mathrm{T}$ & $\mathrm{cp}^{+}>\mathrm{py}=$, mb, rt-LCX. \\
\hline 28 & $\mathrm{~T}-3$ & 2 & 2 & 1 & & 2 & 5 & $\mathrm{~T}$ & $\mathrm{~T}$ & - & $\mathrm{T}$ & $\mathrm{cp} \geq \mathrm{py}, \mathrm{mg} \pm \mathrm{rt}-\mathrm{LCX} \pm \mathrm{hm} \pm \mathrm{mb} \pm$ bor \\
\hline 29 & G-1 & 1 & & & 1 & 1 & 2 & - & - & $\mathrm{T}$ & $\mathrm{T}$ & $\mathrm{mg}, \mathrm{hm}$ \\
\hline 30 & G-2 & 4 & & & 4 & 2 & 6 & - & - & $\mathrm{T}$ & $\mathrm{T}$ & $m g, p y^{\prime} \pm c p^{=}$ \\
\hline 31 & $\mathrm{~S}-3$ & & & & & & & - & - & - & - & $\mathrm{cp}^{+}>\mathrm{py}^{-} \cong \mathrm{mg}^{-}$ \\
\hline 32 & $\mathrm{R}-4$ & & & & & & & - & - & - & - & rt-LCX, mg, cp > py, hm, bor, cv \\
\hline 33 & $\mathrm{P}-4$ & & & & & & & - & - & - & - & $\mathrm{cp}^{+}>\mathrm{py}, \mathrm{rt}-\mathrm{LCX}$ \\
\hline 34 & Q-2 & & & & & & & - & - & - & - & $\mathrm{cp}^{++}>\mathrm{py}^{-}, \mathrm{rt}, \mathrm{mb}$ \\
\hline 35 & $\mathrm{P}-2$ & & & & & & & - & - & - & - & $\mathrm{cp}^{+}>\mathrm{py}^{-} \pm \mathrm{rt} \pm$ bor \\
\hline 36 & $\mathrm{R}-1$ & & & & & & & - & - & - & - & cp, py, mb \pm rt-LCX \\
\hline 37 & $\mathrm{H}-4$ & 14 & 9 & & 6 & 10 & 25 & $\mathrm{~T}$ & - & $\mathrm{T}$ & $\mathrm{T} / \mathrm{E}$ & py $>$ cp \pm rt, hm-, bor $=$ \\
\hline 38 & $\mathrm{C}-2$ & 17 & 12 & & 6 & 16 & 34 & $\mathrm{~T} / \mathrm{E}$ & - & $\mathrm{T}$ & E & $\mathrm{py} \cong \mathrm{cp}, \mathrm{mb}, \mathrm{mg}, \mathrm{rt}-\mathrm{LCX}, \mathrm{mg}$ \\
\hline 39 & $\mathrm{C}-1$ & 3 & 1 & & 2 & 3 & 6 & $\mathrm{~T}$ & - & $\mathrm{T}$ & $\mathrm{T}$ & $\mathrm{cp}^{-} \cong \mathrm{py}^{-}, \mathrm{rt}, \mathrm{mb}^{+}$ \\
\hline 40 & $\mathrm{H}-3$ & 2 & 2 & & & 2 & 4 & $\mathrm{~T}$ & - & - & $\mathrm{T}$ & py > cp', ef (?), hm (?) \\
\hline 41 & G-3 & 2 & & & 2 & 1 & 3 & - & - & $\mathrm{T}$ & $\mathrm{T}$ & $\mathrm{mg}^{+}, \mathrm{py}>\mathrm{cp}^{-}, \mathrm{hm}^{=}$ \\
\hline 42 & A-1 & & & & & & & - & - & - & - & $\mathrm{py} \cong \mathrm{cp}, \mathrm{mg}$ \\
\hline 43 & $\mathrm{D}-2$ & & & & & & & - & - & - & - & $\mathrm{cp}>\mathrm{py}, \mathrm{mg}=$ \\
\hline 44 & $\mathrm{I}-2$ & & & & & & & - & - & - & - & py > cp, rt-LCX, bor $=(?)$ \\
\hline 45 & $\mathrm{I}-3$ & & & & & & & - & - & - & - & $\mathrm{py} \cong \mathrm{cp} \pm$ bor $\pm \mathrm{rt}-\mathrm{LCX} \pm \mathrm{hm} \pm \mathrm{mg} \pm \mathrm{cv} \pm \mathrm{dg}(?)$ \\
\hline 46 & A-2 & & & & & & & - & - & - & - & rt, py \\
\hline 47 & A-3 & & & & & & & - & - & - & - & py, rt-LCX \\
\hline 48 & $\mathrm{R}-2$ & & & & & & & - & - & - & - & LCX, mg-hm, cp, py, ef \\
\hline 49 & $\mathrm{U}-3$ & 20 & 11 & 2 & 8 & 18 & 39 & $\mathrm{~T} / \mathrm{E}$ & $\mathrm{T}$ & $\mathrm{T}$ & E & py > cp, mb, rt-LCX \\
\hline 50 & $\mathrm{~F}-1$ & 43 & 12 & 10 & 30 & 40 & 92 & $\mathrm{~T} / \mathrm{E}$ & $\mathrm{T}$ & M & $\mathrm{F}$ & py > cp-, rt-LCX \\
\hline 51 & $\mathrm{~T}-1$ & 6 & 6 & 1 & 3 & 6 & 16 & $\mathrm{~T}$ & $\mathrm{~T}$ & $\mathrm{~T}$ & $\mathrm{~T}$ & $\mathrm{cp} \cong \mathrm{py}, \mathrm{rt}-\mathrm{LCX}, \mathrm{mb}$ \\
\hline 52 & B-2 & 7 & 2 & 1 & 5 & 6 & 14 & $\mathrm{~T}$ & $\mathrm{~T}$ & $\mathrm{~T}$ & $\mathrm{~T}$ & py > cp-, mg, rt \\
\hline 53 & $\mathrm{~J}-2$ & 17 & 4 & 3 & 14 & 15 & 36 & $\mathrm{~T}$ & $\mathrm{~T}$ & E & E & $\mathrm{mg}^{+}, \mathrm{LCX}, \mathrm{py}>\mathrm{cp}, \mathrm{hm}=$ \\
\hline 54 & $\mathrm{I}-3$ & 3 & & 1 & 3 & 1 & 5 & - & $\mathrm{T}$ & $\mathrm{T}$ & $\mathrm{T}$ & $\mathrm{cp}>\mathrm{py}, \mathrm{rt}-\mathrm{LCX} \pm \mathrm{ef} \pm \mathrm{gl} \pm \mathrm{mg} \pm \mathrm{hm}$ \\
\hline 55 & $\mathrm{O}-2$ & 6 & 4 & & 2 & 6 & 12 & $\mathrm{~T}$ & - & $\mathrm{T}$ & $\mathrm{T}$ & cp > py, mb, hm \\
\hline 56 & $\mathrm{~S}-2$ & & & & & & & - & - & - & - & cp > py, rt-LCX, mg-hm \\
\hline 57 & $\mathrm{~J}-4$ & 47 & 4 & 12 & 42 & 44 & 102 & $\mathrm{~T}$ & $\mathrm{~T} / \mathrm{E}$ & $\mathrm{F}$ & $\mathrm{F}$ & py > cp, mg, rt-LCX \\
\hline 58 & $\mathrm{U}-1$ & 23 & 13 & 3 & 10 & 23 & 49 & $\mathrm{E} / \mathrm{T}$ & $\mathrm{T}$ & $\mathrm{T} / \mathrm{E}$ & $\mathrm{E} / \mathrm{M}$ & cp > py, rt-LCX \\
\hline 59 & $\mathrm{~N}-2$ & 30 & 13 & 2 & 18 & 30 & 63 & $\mathrm{E} / \mathrm{T}$ & $\mathrm{T}$ & $\mathrm{E}$ & M & py $^{+}>$cp, rt-LCX \pm mg (?) \\
\hline 60 & $\mathrm{~J}-3$ & 15 & 1 & 5 & 11 & 15 & 32 & $\mathrm{~T}$ & $\mathrm{~T}$ & $\mathrm{~T} / \mathrm{E}$ & E & py, cp, rt, mg, bor $=$ \\
\hline 61 & $\mathrm{I}-4$ & 2 & 1 & 1 & 1 & 2 & 5 & $\mathrm{~T}$ & $\mathrm{~T}$ & $\mathrm{~T}$ & $\mathrm{~T}$ & py, cp, rt-LCX, mg-hm, ef (?) \\
\hline 62 & M-4 & 23 & 4 & & 20 & 21 & 45 & $\mathrm{~T}$ & - & E & E & $\mathrm{py}^{+}, \mathrm{rt}-\mathrm{LCX}, \mathrm{cp}$ \\
\hline 63 & $\mathrm{U}-2$ & 15 & 9 & & 6 & 13 & 28 & $\mathrm{~T}$ & - & $\mathrm{T}$ & $\mathrm{E} / \mathrm{T}$ & $\mathrm{cp} \geq \mathrm{py}, \mathrm{rt}-\mathrm{LCX}, \mathrm{mb}$ \\
\hline 64 & $\mathrm{P}-1$ & & & & & & & - & - & - & - & cp > py, rt-LCX, mg, mb \\
\hline 65 & D-1 & & & & & & & - & - & - & - & py $>$ cp, mb, LCX \pm bor \pm cv \pm hm (?) \\
\hline 66 & $\mathrm{~J}-1$ & 23 & 11 & 5 & 12 & 21 & 49 & $\mathrm{~T} / \mathrm{E}$ & $\mathrm{T}$ & $\mathrm{T} / \mathrm{E}$ & E & $\mathrm{py}^{\prime} \geq \mathrm{cp}-, \mathrm{rt}-\mathrm{LCX} \pm \mathrm{cv}=$ \\
\hline 67 & O-1 & 63 & 34 & 4 & 27 & 61 & 126 & M & $\mathrm{T}$ & $\mathrm{M}$ & A & py $\geq \mathrm{cp}$ \\
\hline 68 & Q-1 & 29 & 10 & 5 & 17 & 27 & 59 & $\mathrm{~T} / \mathrm{E}$ & $\mathrm{T}$ & $\mathrm{E}$ & M & $\mathrm{py} \cong \mathrm{cp} \pm$ bor" $\mathrm{mb}^{-}$, ef \\
\hline 69 & $\mathrm{~L}-3$ & 6 & 5 & & 1 & 6 & 12 & $\mathrm{~T}$ & - & $\mathrm{T}$ & $\mathrm{T}$ & py $>$ cp, \pm cv $= \pm$ bor $=$ \\
\hline 70 & $\mathrm{~L}-2$ & 2 & 2 & & & 2 & 4 & $\mathrm{~T}$ & - & - & $\mathrm{T}$ & py $>$ cp, \pm bor $=c c^{=}$ \\
\hline 71 & $\mathrm{~K}-2$ & 3 & & & 3 & & 3 & - & - & $\mathrm{T}$ & - & $\mathrm{py}^{+}>\mathrm{cp}^{-}$, CGRs (?), bor, cv, gl, ef \\
\hline 72 & $\mathrm{~L}-1$ & 1 & 1 & & & 1 & 2 & $\mathrm{~T}$ & - & - & $\mathrm{T}$ & $\mathrm{py}>\mathrm{cp}=$ \\
\hline 73 & M-3 & 1 & & & 1 & 1 & 2 & - & - & $\mathrm{T}$ & $\mathrm{T}$ & $\mathrm{LCX}, \mathrm{py}>\mathrm{cp}=\mathrm{cv}^{=}$, bor $^{=}$ \\
\hline 74 & $\mathrm{~N}-1$ & 2 & 1 & & 1 & 2 & 4 & $\mathrm{~T}$ & - & $\mathrm{T}$ & $\mathrm{T}$ & $\mathrm{py}^{+}>\mathrm{cp}=$, rt-LCX, $\pm \mathrm{cv}, \mathrm{cc}$, bor, CGRs (?) \\
\hline 75 & $\mathrm{~K}-1$ & 3 & 2 & & 1 & 3 & 6 & $\mathrm{~T}$ & - & $\mathrm{T}$ & $\mathrm{T}$ & py $^{+}$, rt-LCX, bor, cv, CGRs (?), arsenopirita (?) \\
\hline 76 & $\mathrm{M}-2$ & & & & & & & - & - & - & - & py > cp, rt-LCX, bor $={ }^{\prime},{ }^{=}, c c^{=}$ \\
\hline 77 & M-1 & & & & & & & - & - & - & - & $\mathrm{rt}-\mathrm{LCX}, \mathrm{py}^{+}, \mathrm{cv}^{=}, \mathrm{cc}^{=}$ \\
\hline & & 824 & 302 & 83 & 521 & 695 & 1601 & & & & & \\
\hline & & & 18,863 & 5,1843 & 32,542 & 43,4 & & & & & & \\
\hline
\end{tabular}


A Figura 7.5, por sua vez, compara as freqüências entre os tipos de intercrescimentos observados nas jazidas de Cuajone, Cerro Verde, Toromocho e Quellaveco, estas três últimas estudadas por Canchaya (1993). Os resultados mostram que os tipos cp/mck:1e, cp/cb:1a, cp/cb:3a são comuns nas quatro jazidas, já os tipos cp/mck:1b e cp/po:1b só aparecem nas jazidas de Cuajone, Cerro Verde e Toromocho, enquanto o tipo py/po:1e, é muito freqüente para as jazidas de Cuajone e Toromocho e o tipo cp/mck:1e é muito freqüente nas jazidas Quellaveco, Cerro Verde e Toromocho e apenas freqüênte em Cuajone.

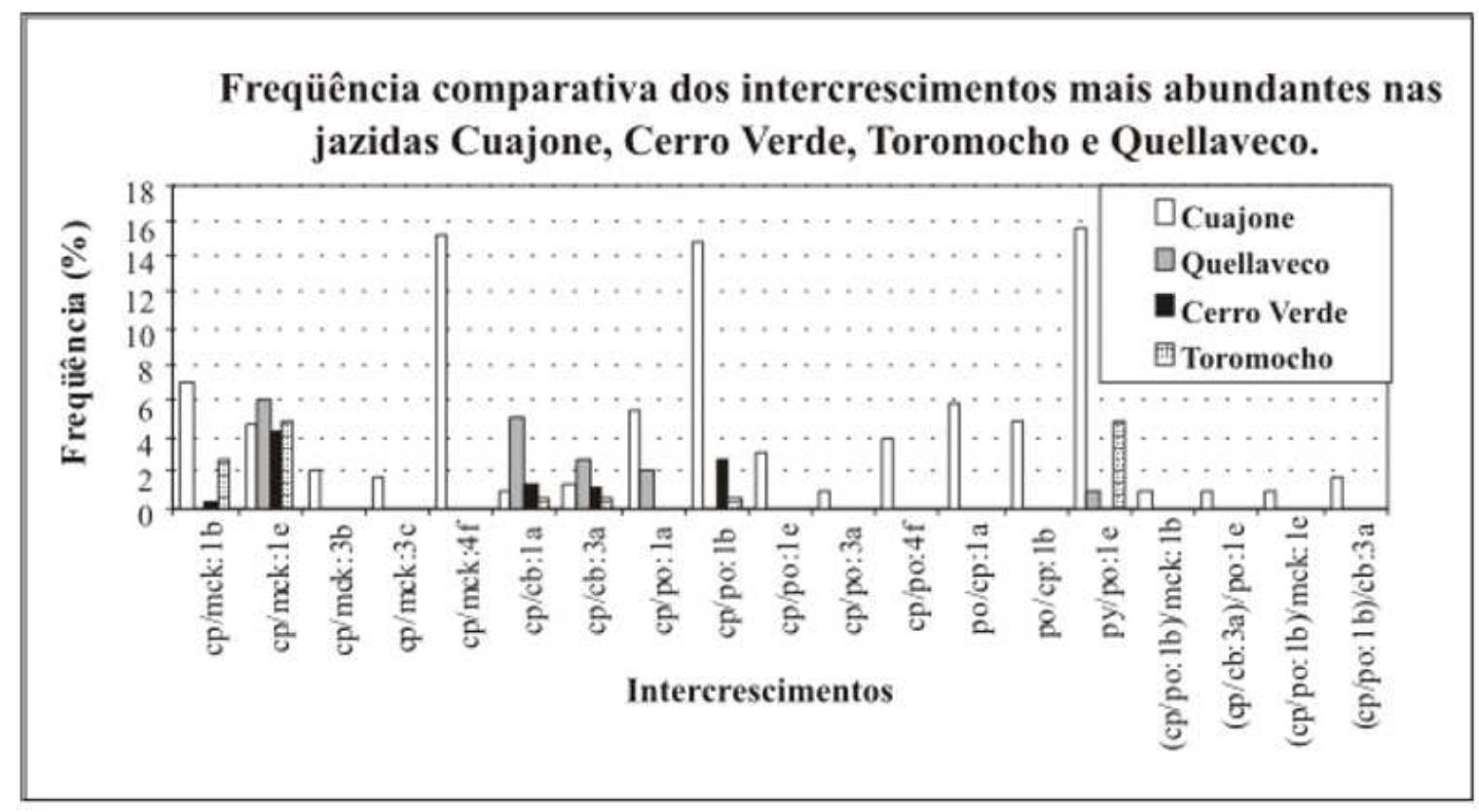

Figura 7.5: Freqüência relativa dos intercrescimentos mais abundantes nas jazidas Cuajone, Cerro Verde, Toromocho e Quellaveco.

\subsection{Correlação entre os tipos de Intercrescimentos e as Al- terações Hidrotermais}

Paralelamente ao estudo morfológico e da distribuição quantitativa das inclusões sólidas foi feito um estudo dos tipos de alterações presentes na jazida de Cuajone, conforme apresentado no Capítulo 6. A seguir são discutidas as correlações preliminares observadas entre os tipos de alteração hidrotermal e a distribuição das inclusões sólidas, baseadas no estudo das 77 amostras representativas selecionadas.

Nesta análise foram considerados os tipos mais freqüentes de intercrescimentos encontrados, o limite estabelecido para cada tipo de alteração é mostrado nas tabelas do Anexo 7; apenas no caso das alterações potássica e propílica-fílica, devido à pequena quantidade de amostras representativas, todos os intercrescimentos foram considerados. Observa-se que pirrotita, cubanita e mackinawita, além de caracterizarem as inclusões, mostram afinidades com 
os diferentes padrões de alteração hidrotermal; deve ser destacado que a calcopirita está quase sempre associada a estes minerais.

\section{Alteração potássica}

Neste tipo de alteração parecem seis tipos de intercrescimentos simples ( $c f$. Anexo 7.1). Os intercrescimentos mais abundantes correspondem aos tipos cp/po:1b e py/po:1e e, nestes a pirrotita está sempre presente. Os intercrescimentos de tipo cp/mck:1e, cp/mck:4f, cp/po:4f e po/cp:1a são os menos freqüentes e importantes (Figura 7.6).

A ordem de abundância relativa dos minerais que tipificam as inclusões, incluindo todos os tipos de intercrescimentos observados é: pirrotita, a mais abundante (46,7\%), seguida por mackinawita (13,3\%). A cubanita está tipicamente ausente (Figura 7.7). Se considerarmos somente os intercrescimentos mais abundantes, pirrotita é o mineral mais característico (Figura $7.8)$.

\section{Alteração potássica-propílica}

São descritos um total de 34 tipos de intercrescimentos (Anexo 7.2) sendo quinze, entre eles os mais abundantes e importantes e, destes, treze são de tipo simples e dois de tipo complexo. Os intercrescimentos simples cp/po:1a, cp/po:1b, cp/po:1e, cp/po:4f, po/cp:1a, po/cp:1b e py/po:1e são aqueles que apresentam pirrotita, entre os quais os intercrescimentos py/po:1e, cp/po:1b, cp/po:1a e cp/po:4f apresentam as porcentagens mais elevadas de freqüência. Os intercrescimentos cp/mck:1b, cp/mck:1e, cp/mck:3b, cp/mk:4f e cp/mck:1b;1e são caracterizados pela presença de mackinawita, sendo que o tipo mais freqüente corresponde ao intercrescimento $\mathrm{cp} /$ mck: 4f, seguido por $\mathrm{cp} / \mathrm{mck}: 1 \mathrm{~b}$. O intercrescimento $\mathrm{cp} / \mathrm{cb}: 1 \mathrm{a}$, com cubanita, é pouco freqüente.

Os dois tipos de intrecrescimentos complexos encontrados são pouco freqüentes, um é caracterizado pela associação de pirrotita com mackinawita $[(\mathrm{cp} / \mathrm{po}: 1 \mathrm{~b}) / \mathrm{mck}: 1 \mathrm{e}]$, o outro pela associação de pirrotita com cubanita [(cp/po:1b)/cb:3a] (Figura 7.9).

Quanto os minerais que tipificam as inclusões, deve ser destacado que a pirrotita (45\%) é a fase mais freqüente, seguida pela mackinawita $(14,6 \%)$ e pela cubanita, esta pouco freqüente $(1,7 \%)$, (Figura 7.10). A cubanita sempre participa dos intercrescimentos menos freqüentes.

\section{Alteração propílica - potássica}

Foram caracterizados 31 diferentes tipos de intercrescimentos (Anexo 7.3) nas zonas propílica-potássicas, dos quais 16 são os mais freqüentes e importantes, sendo quinze de tipo simples e um complexo. Entre os intercrescimentos com participação de mackinawita, cp/mck:1b, cp/mck:1c, cp/mck:1e, cp/mck:3b, cp/mck:3c, cp/mck:4f, os tipos cp/mck:4f e cp/mck:1b 


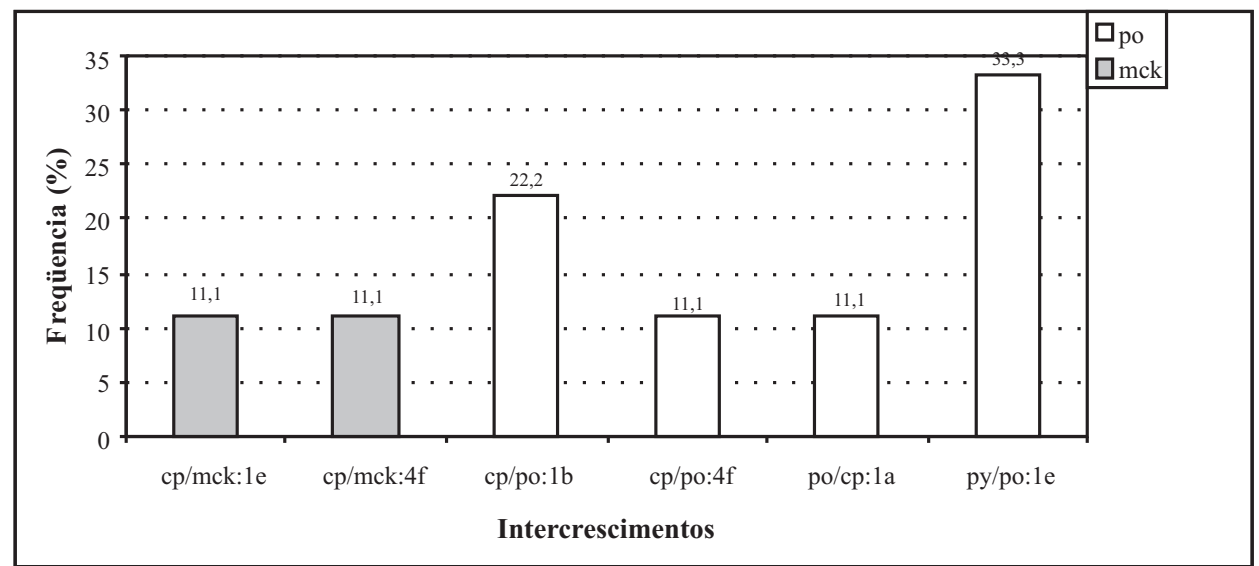

Figura 7.6: Freqüência comparativa dos intercrescimentos mais abundantes nas zonas de alteração potássica.

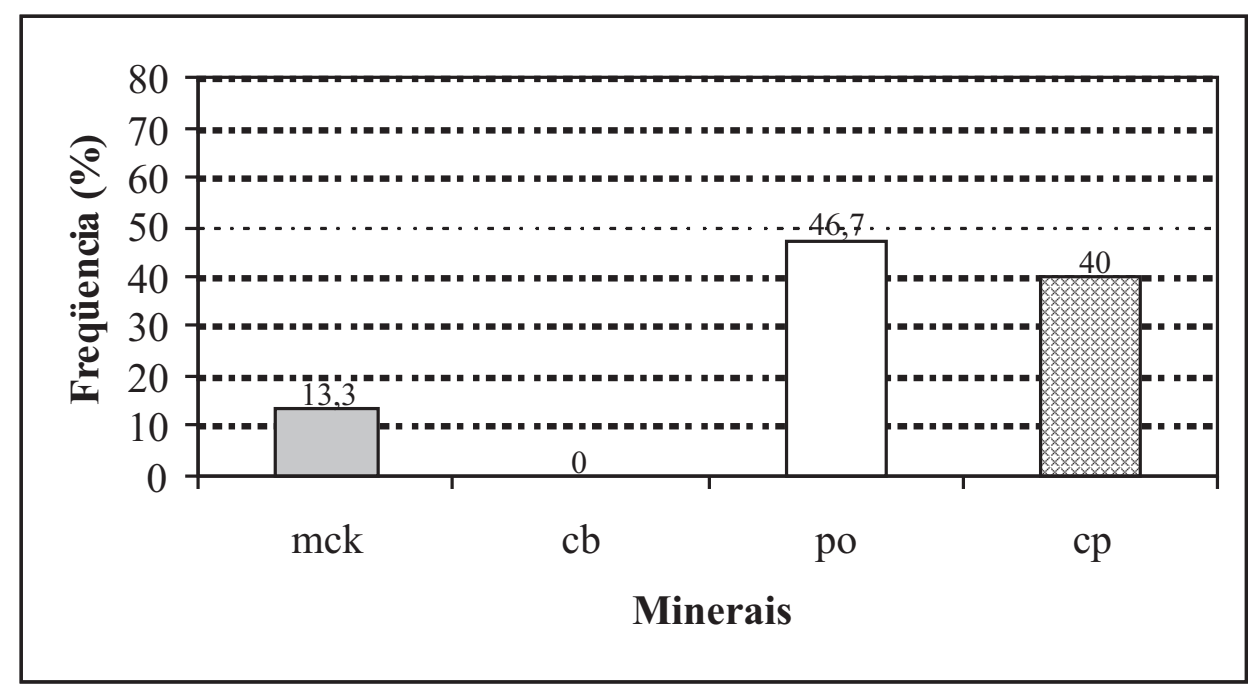

Figura 7.7: Frequiência dos minerais que tipificam todos os intercrescimentos observados nas zonas de alteração potássica.

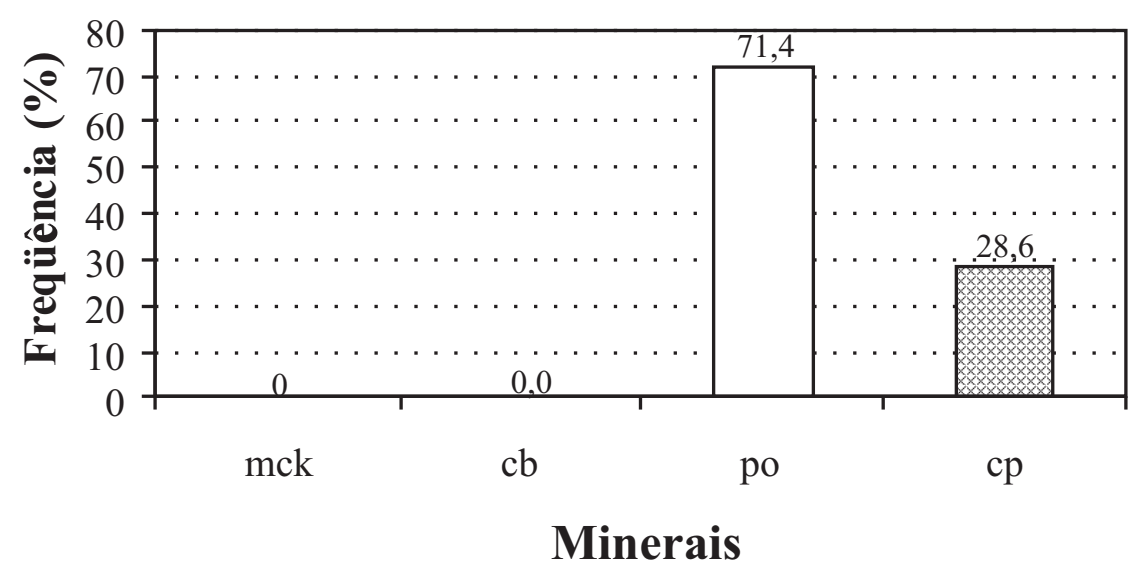

Figura 7.8: Frequência dos minerais que tipificam os intercrescimentos mais abundantes nas zonas de alteração potássica. 


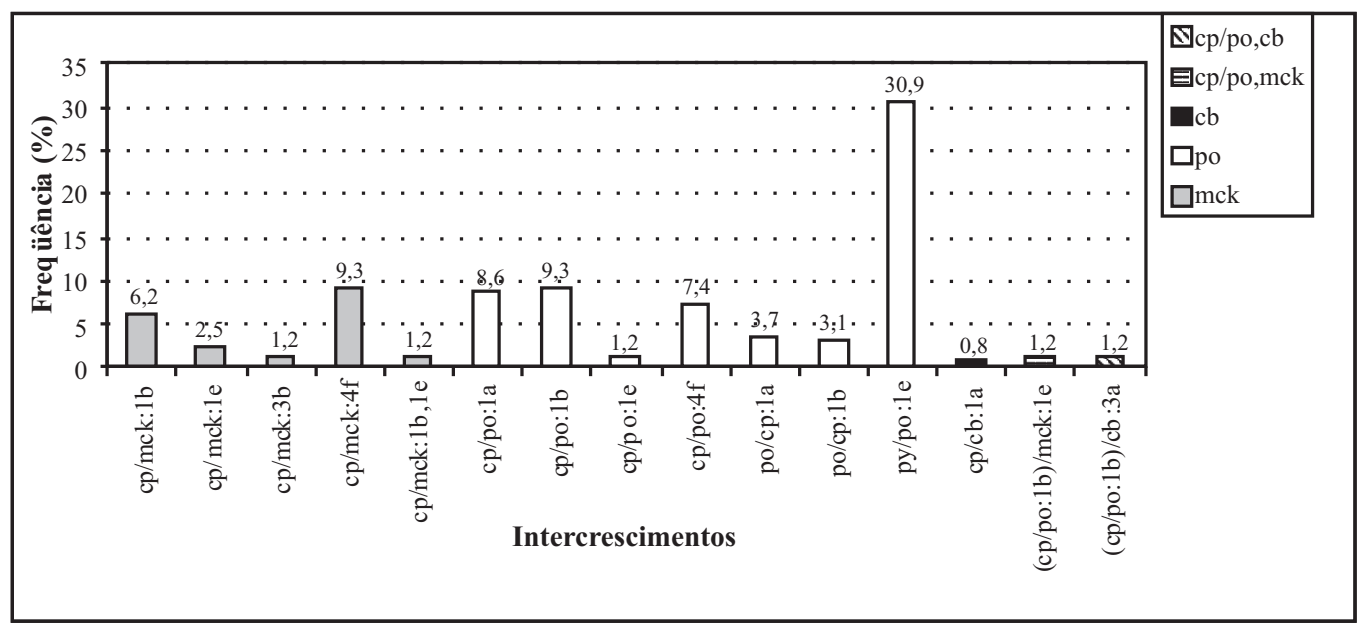

Figura 7.9: Freqüência comparativa dos intercrescimentos mais abundantes nas zonas de alteração potássica-propílica.

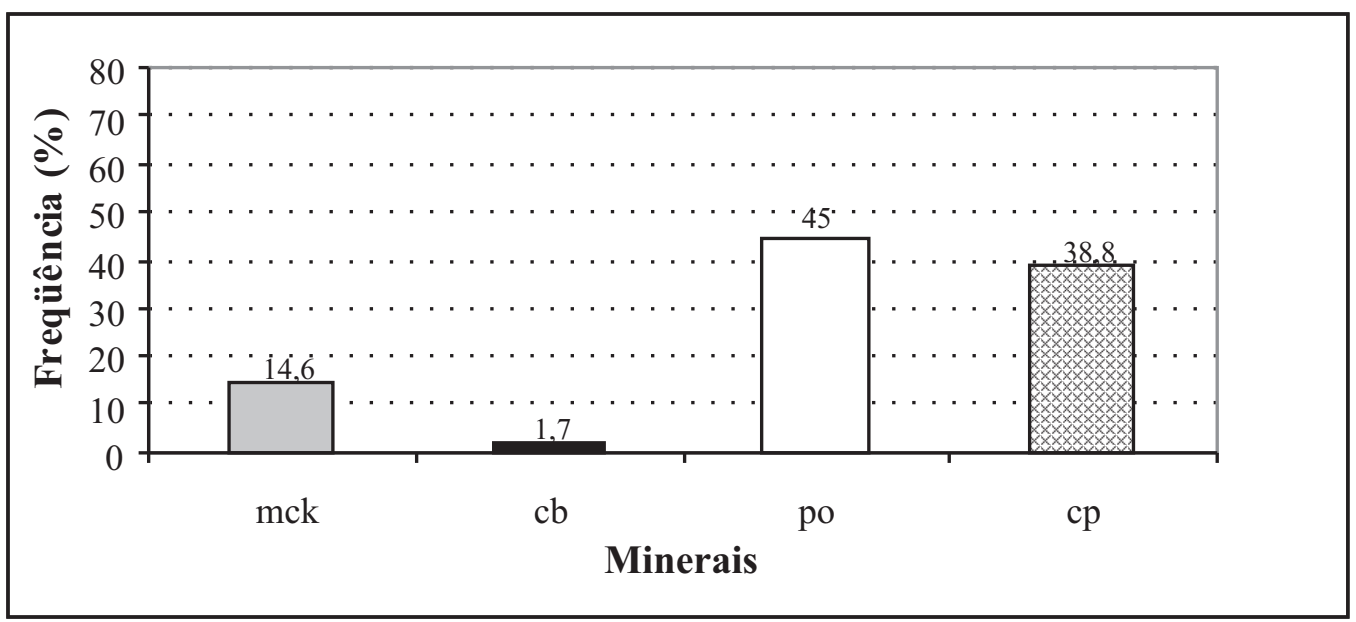

Figura 7.10: Freqüência dos minerais que tipificam os intercrescimentos nas zonas de alteração potássica-propílica.

são os mais freqüentes. Entre os intercrescimentos com participação de pirrotita, cp/po:1a, cp/po:1b, cp/po:1e, cp/po:3a cp/po:4f, po/cp:1a, po/cp:1b e py/po:1e, os tipos cp/po:1e, $\mathrm{cp} / \mathrm{po}: 1 \mathrm{~b}, \mathrm{po} / \mathrm{cp}: 1 \mathrm{a}, \mathrm{po} / \mathrm{cp}: 1 \mathrm{~b}$ apresentam as maiores porcentagens relativas.

O intercrescimento simples cp/cb:3a, com cubanita e o intercrescimento complexo (cp/po:1b)/mck:1b, com pirrotita associada à mackinawita são menos abundantes (Figura 7.11).

Entre os minerais presentes nestas zonas de alteração, a pirrotita é mais freqüente $(36,0 \%)$ seguida pela mackinawita $(19,6 \%)$ e pela cubanita, pouco importante $(0,5 \%)$. A principal diferença, quando se compara com a alteração potássica-propílica, é que neste tipo de alteração, as frequiências de cubanita e pirrotita diminuem, enquanto que a da mackinawita aumenta (Figura 7.12). 


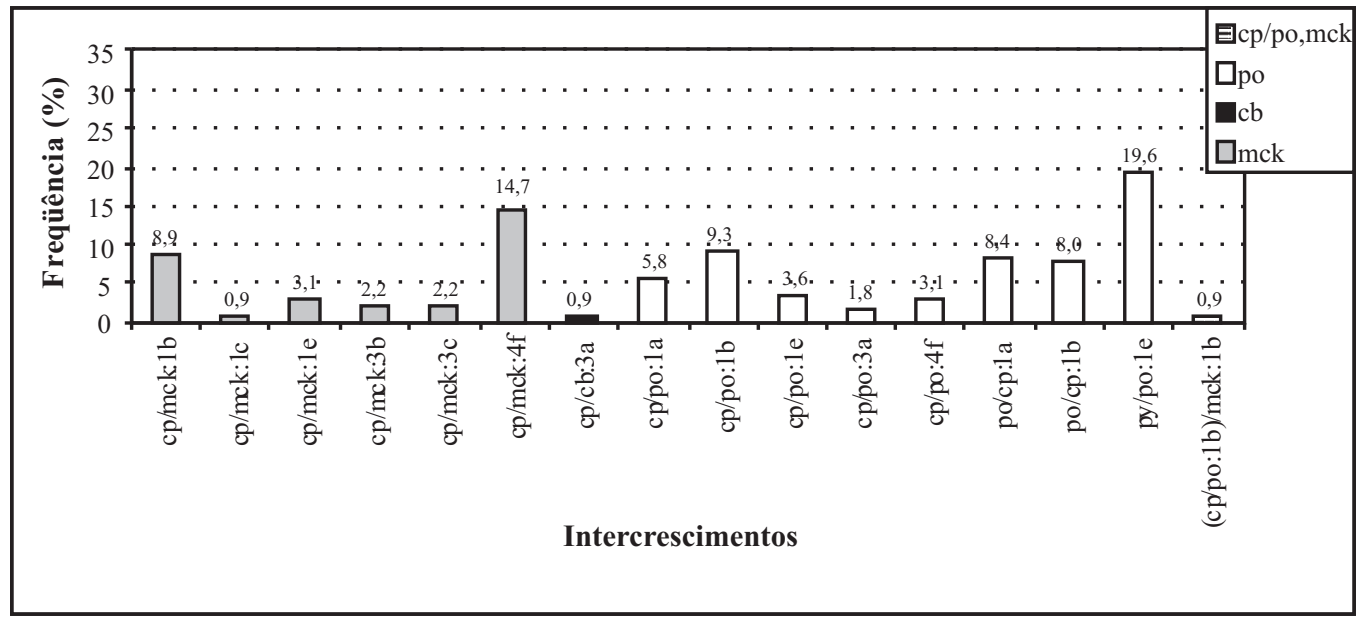

Figura 7.11: Freqüência comparativa dos intercrescimentos mais abundantes nas zonas de alteração propílica-potássica.

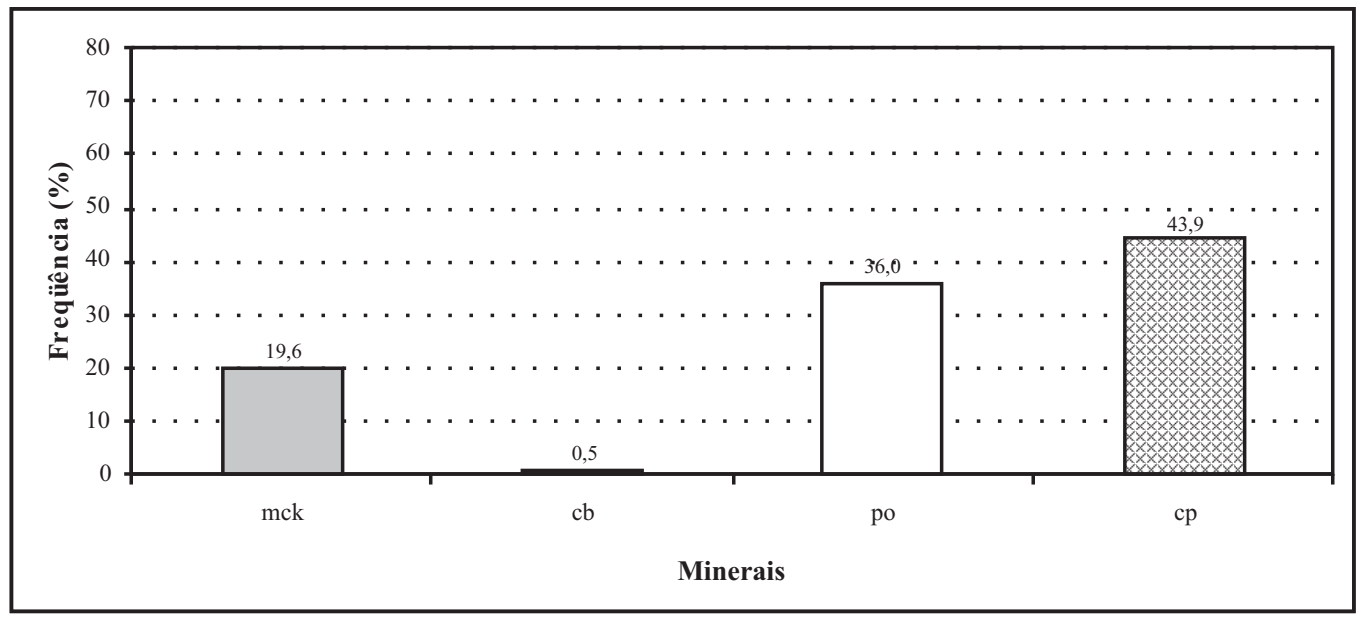

Figura 7.12: Freqüência dos minerais que tipificam os intercrescimentos nas zonas de alteração propílica-potássica.

\section{Alteração propílica}

São em número de dez os intercrescimentos observados neste tipo de alteração (Anexo 7.4), dos quais 6 são intercrescimentos comparativamente importantes. Cinco são de tipo simples e um de tipo complexo. Três intercrescimentos incluem participação de mackinawita, cp/mck:1b, cp/mck:1e, cp/mck:4f, entre os quais o tipo cp/mck:4f é o mais importante. Entre os intercrescimentos com participação de pirrotita, po/cp:1a e py/po:1e, o tipo py/po:1e é o mais freqüente. O intercrescimento complexo (cp/po:1b)/mck:1b é o menos importante (Figura $7.13)$.

Mackinawita é fase mineral mais freqüente (33,3\%), seguida pela pirrotita (16.7\%); cubanita é tipicamente ausente (Figura 7.14). A comparação com os dados apresentados anteriormente mostra que nas zonas de alteração propílica, a mackinawita torna-se mais importante, enquanto que a freqüência de pirrotita diminui. 


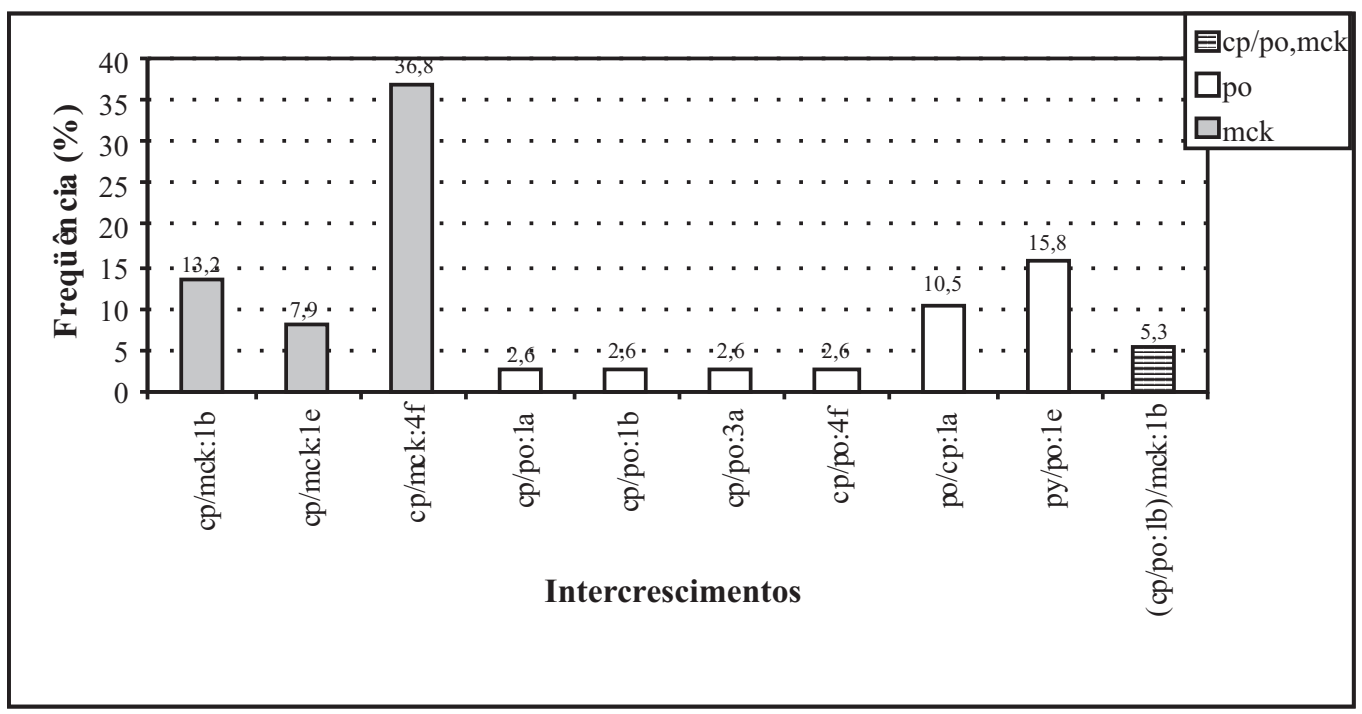

Figura 7.13: Freqüência comparativa dos intercrescimentos mais abundantes nas zonas de alteração propílica.

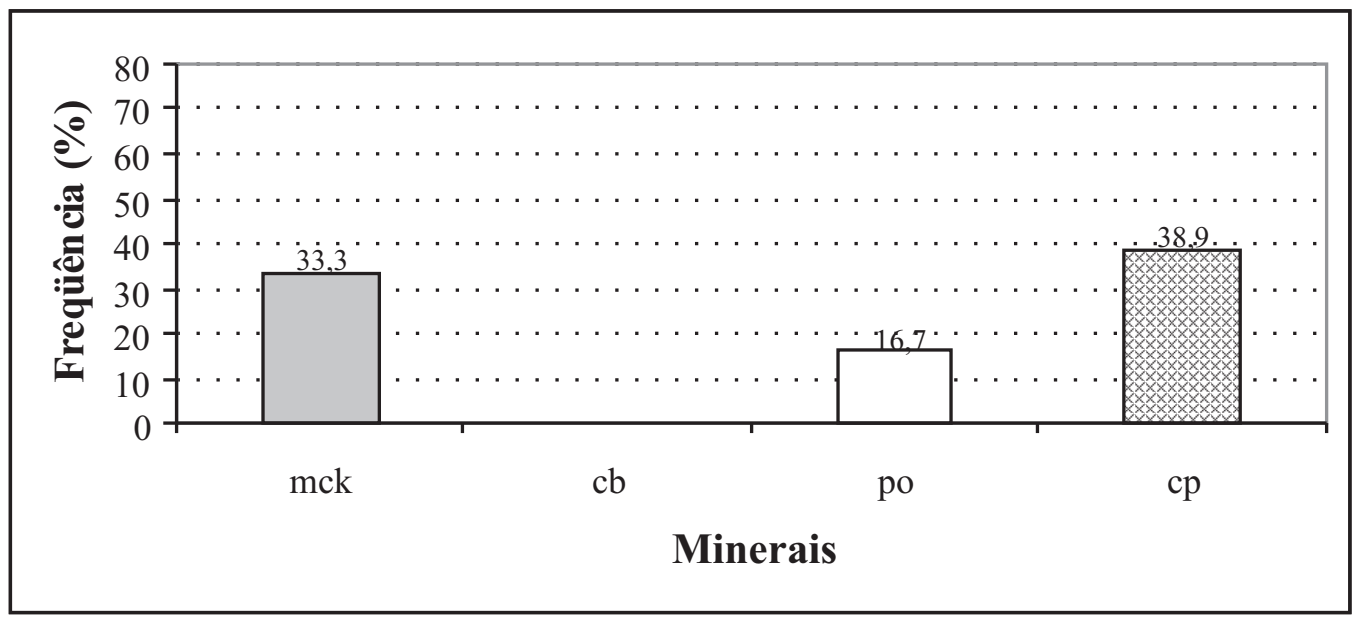

Figura 7.14: Freqüência dos minerais que tipificam os intercrescimentos nas zonas de alteração propílica.

\subsection{Alteração potássica-propílica/fílica}

Foram encontrados 24 tipos de intercrescimentos (Anexo 7.5), dos quais dez são comparativamente importantes e, entre eles, nove são simples e um é complexo. Entre os intercrescimentos com pirrotita, de tipo cp/po:1a, cp/po:1b, cp/po:4f, po/cp:1b e py/po:1e, os mais freqëntes são cp/po:1b, cp/po:4f, py/po:1e, ao passo que entre os intercrescimentos com mackinawita, de tipo cp/mck:1b, cp/mck:1e e cp/mck:4f, o mais importante é o de tipo cp/mck:4f. O intercrescimento simples cp/cb:1a e complexo (cp/po:1b)/cb:3a com cubanita e cubanita e pirrotita, respecitvamente apresentam freqüências menores. (Figura 7.15). Nestes intercrescimentos, pirrotita é o mineral mais freqüente $(29,2 \%)$, seguida pela mackinawita $(19,8 \%)$ e pela cubanita $(5,2 \%)$ (Figura 7.16). 


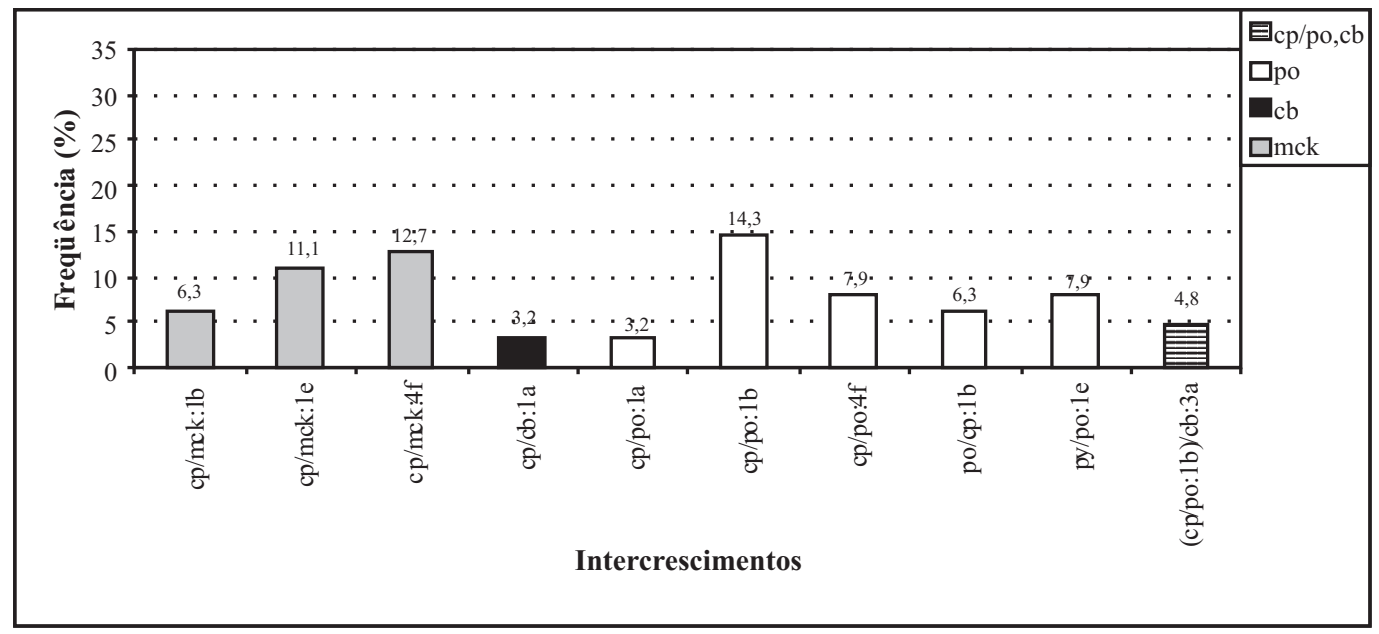

Figura 7.15: Freqüência comparativa dos intercrescimentos mais abundantes nas zonas de alteração potássica-propílica, fílica.

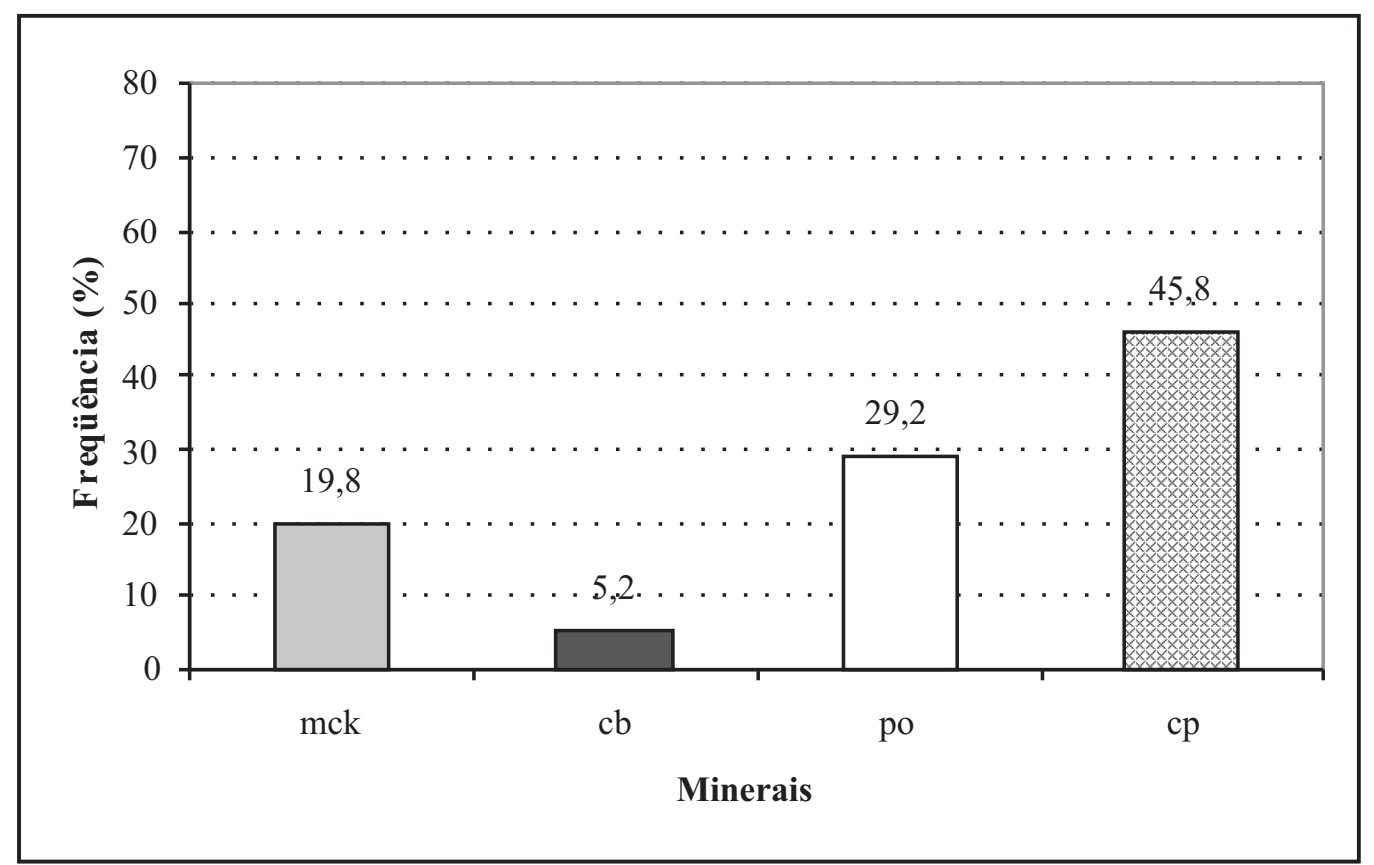

Figura 7.16: Freqüência dos minerais que tipificam os intercrescimentos nas zonas de alteração potássica-propílica, filica.

\section{Alteração propílica-fílica}

Nestas zonas de alteração foram descritos 18 tipos de intercrescimentos (Anexo 7.6); sete entre eles são os mais importantes, dos quais seis são de tipo simples e um complexo. Entre os intercrescimentos cp/mck:1e, e cp/mck:4f, o mais importante é o de tipo cp/mck:4f; já entre os de tipo cp/po:1b, cp/po:4f, po/cp:1a e py/po:1e, o intercrescimento cp/po:1b apresenta o valor, maior seguido por py/po:1e. O intercrescimento complexo (cp/po:1b)/mck:1b e os simples cp/mck:1e e cp/po:4f são relativamente pouco importantes (Figura 7.17).

Nestes intercrescimentos, a fase mais importante é a pirrotita $(37,7 \%)$, seguida pela mac- 


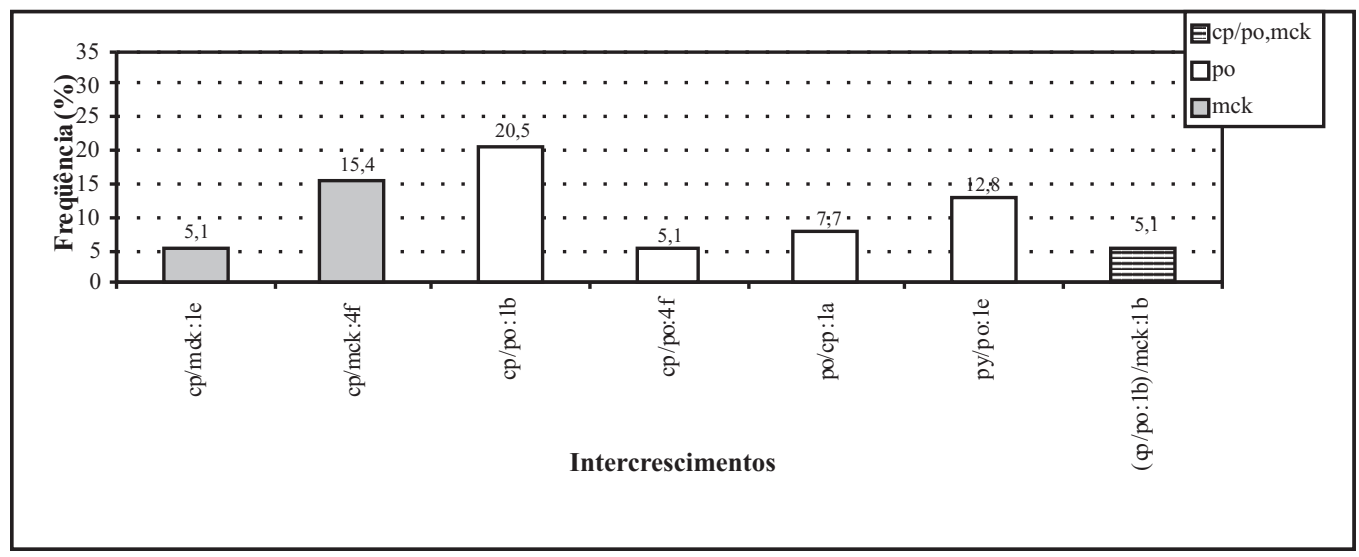

Figura 7.17: Freqüência comparativa dos intercrescimentos mais abundantes nas zonas de alteração propílica-fílica.

kinawita $(18,9 \%)$ (Figura 7.18). Se considerarmos todos os intercrescimentos encontrados, verifica-se que a cubanita também está presente, mas com freqüência muito baixa (Figura 7.19).

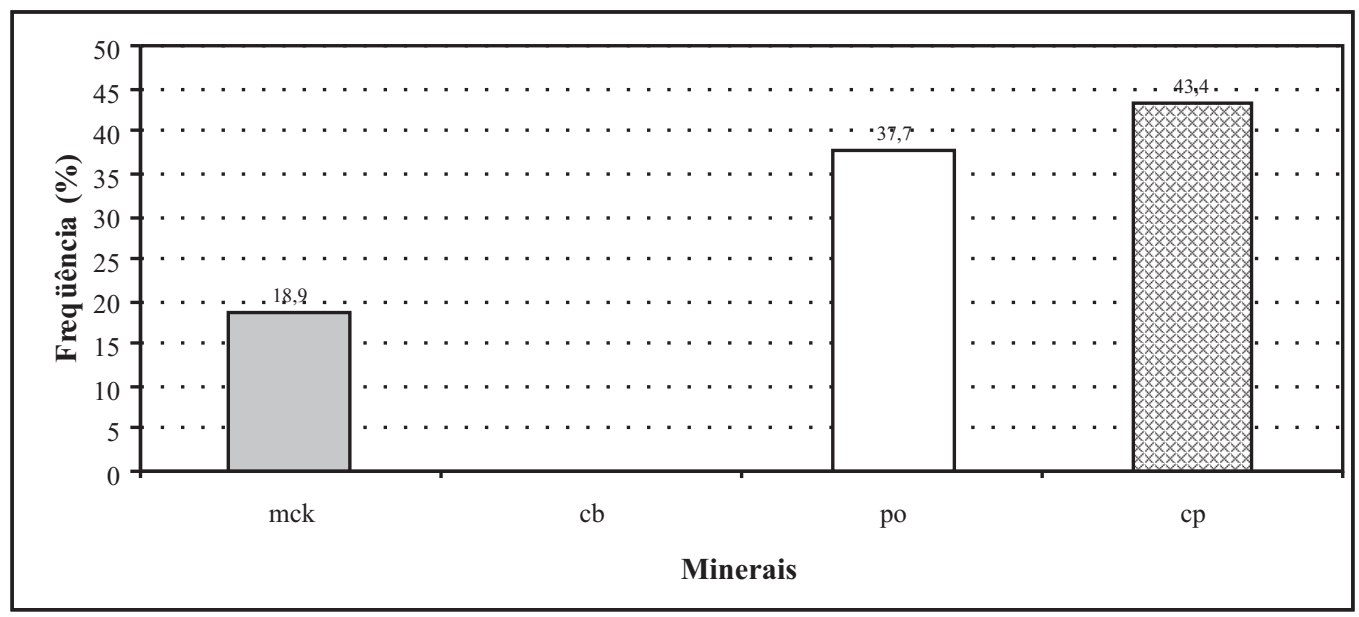

Figura 7.18: Freqüência dos minerais que tipificam os intercrescimentos nas zonas de alteração propílica-fílica.

\section{Alteração fílica-propílica}

Foram encontrados 29 tipos de intercrescimentos (Anexo 7.7), dos quais onze de tipo simples e cinco de tipo complexo são os mais importantes. O intercrescimento simples cp/cb:3a é o único simples com cubanita e o mais importante, os demais são complexos (cp/cb:1a)/po:1e, (cp/cb:3a)/po:1e, (cp/po:1b)/cb:3a. O mais importante com mackinawita (cp/mck:1b, cp/mck:1e, cp/mck:4f) é o de tipo cp/mck:4f. Entre os intercrescimentos simples com pirrotita (cp/po:1a, cp/po:1b, cp/po:1e e cp/po:4f, po/cp:1a po/cp:1b e py/po:1e), o mais importante é o cp/po:1b. Os intercrescimentos complexos (cp/po:1b)/mck:1b e (cp/po:1b)/mck:1e com participação de pirrotita e mackinawita apresentam valores baixos (Figura 7.20). 


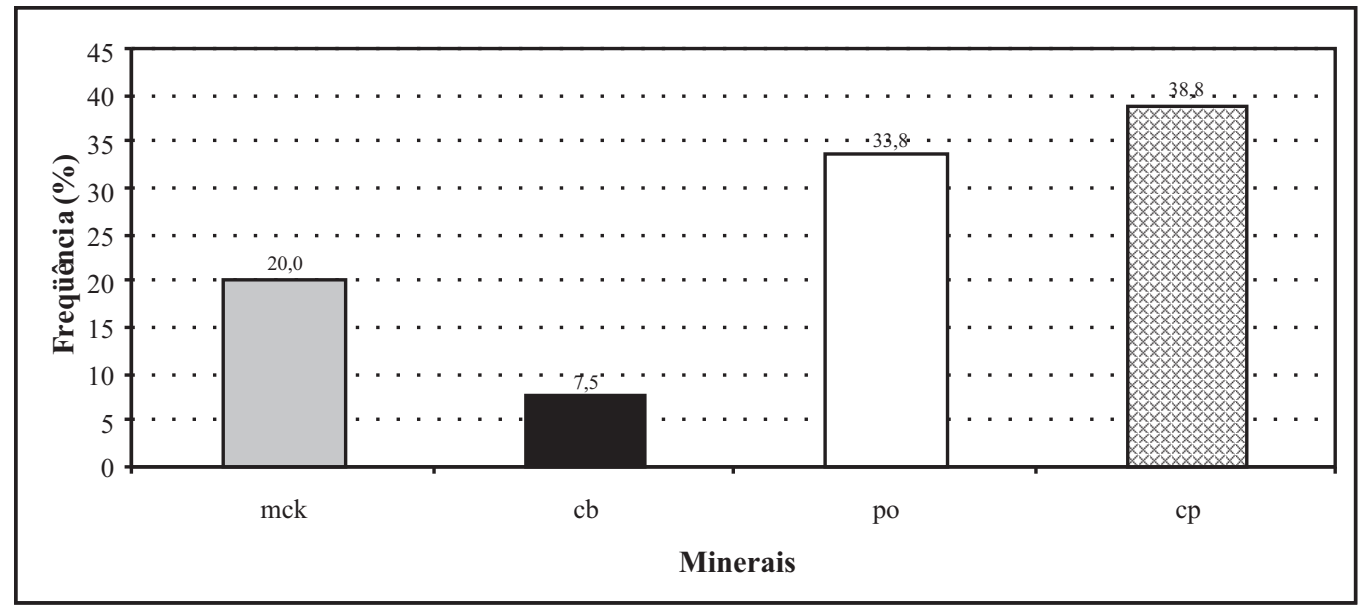

Figura 7.19: Freqüência dos minerais que tipificam os intercrescimentos nas zonas de alteração propílica-fílica, considerando todos os intercrescimentos descritos.

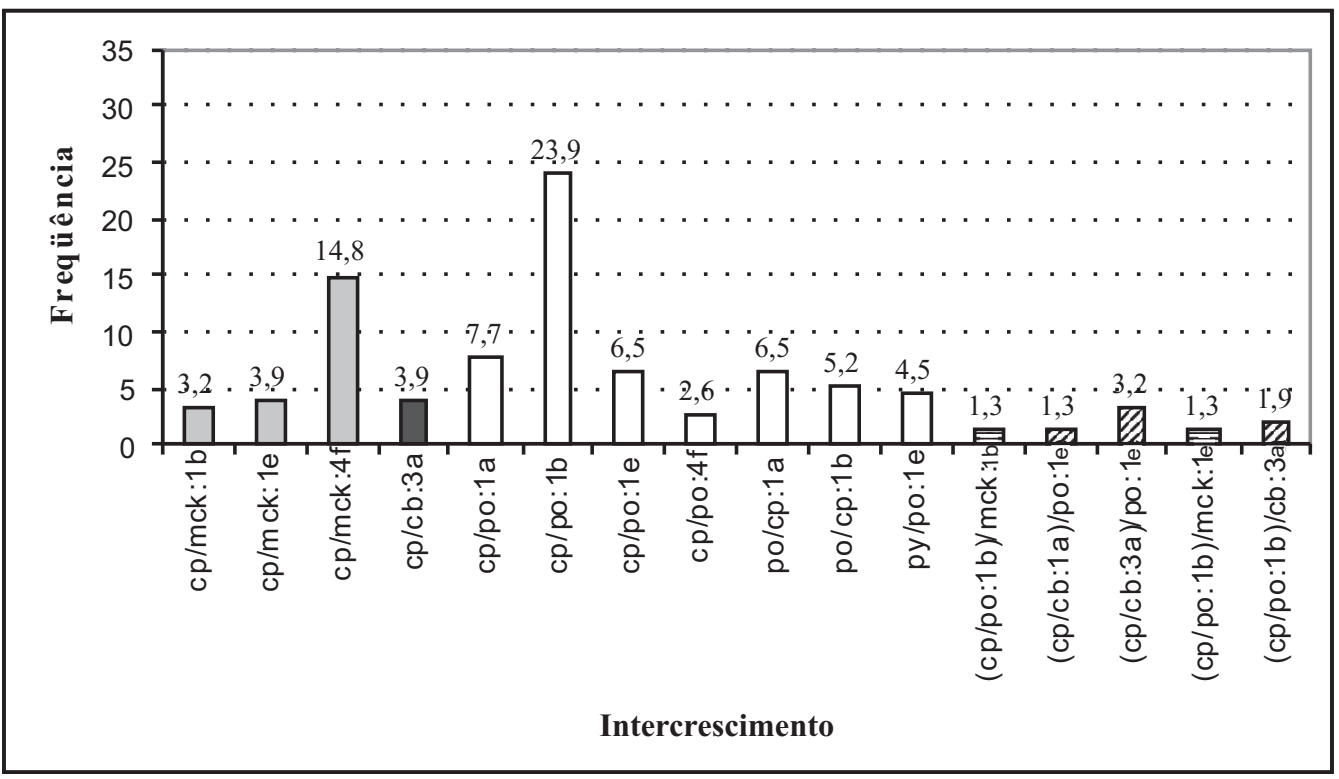

Figura 7.20: Freqüência comparativa dos intercrescimentos mais abundantes nas zonas de alteração fílica-propílica.

Como no caso da alteração propílica-fílica, a pirrotita é a fase mais freqüente $(35,1 \%)$, seguida pela mackinawita $(13,1 \%)$ e pela cubanita $(5,5 \%)$. Entretanto, quando comparada com alteração propílica-fílica (Figura 7.19), a porcentagem na ocorrência de mackinawita diminui, enquanto que a cubanita aumenta e pirrotita diminue levemente, permanecendo quase com o mesmo valor. (Figura 7.21).

\section{Alteração fílica}

Foi caracterizada pela presença de 23 tipos de intercrescimentos (Anexo 7.8), 14 estatisticamente mais importantes, entre os quais doze são simples e dois complexos. Os inter- 


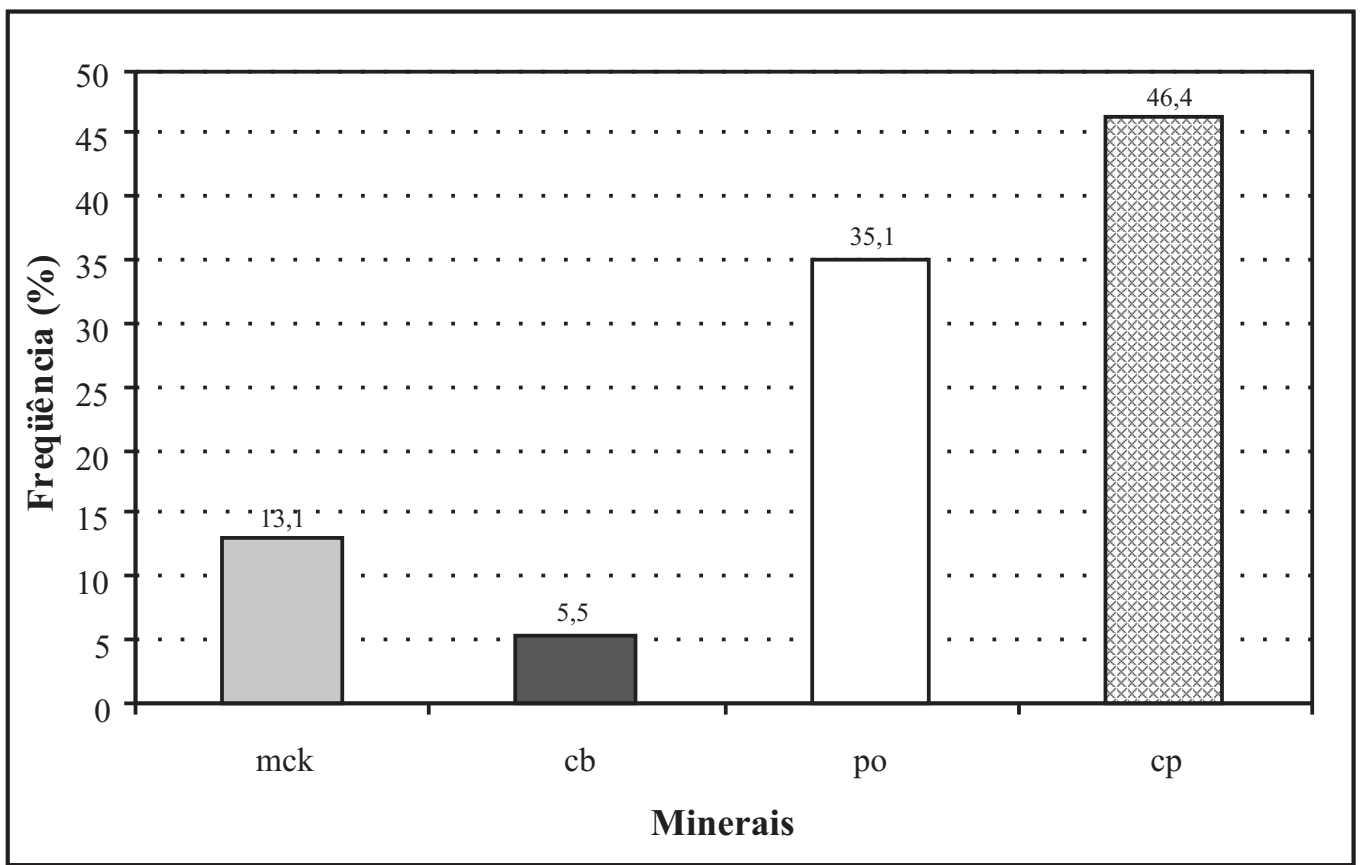

Figura 7.21: Freqüência dos minerais que tipificam os intercrescimentos nas zonas de alteração fílica-propílica.

crescimentos com cubanita são simples $\mathrm{cp} / \mathrm{cb}: 1 \mathrm{a}, \mathrm{cp} / \mathrm{cb}: 3 \mathrm{a}$ ou complexos, onde este mineral encontra-se associado com pirrotita, (cp/cb:3a)/po:1e, (cp/po:1b)/cb:3a. Destes, o intercrescimento (cp/po:1b)/cb:3a é o mais importante. Entre os intercrescimentos simples cp/po:1b, cp/po:1e po/cp:1a, po/cp:1b e py/po:1e, o mais importantes é o cp/po:1b e, entre os intercrescimentos com mackinawita, cp/mck:1b, cp/mck:1e, cp/mck:3b, cp/mck:4f e cp/mck:3c, o mais importante é o de tipo cp/mck:4f. Os intercrescimentos complexos (cp/cb:3a)/po:1e e (cp/po:1b)/cb:3a com participação de pirrotita e cubanita apresentam baixas freqüências (Figura 7.22).

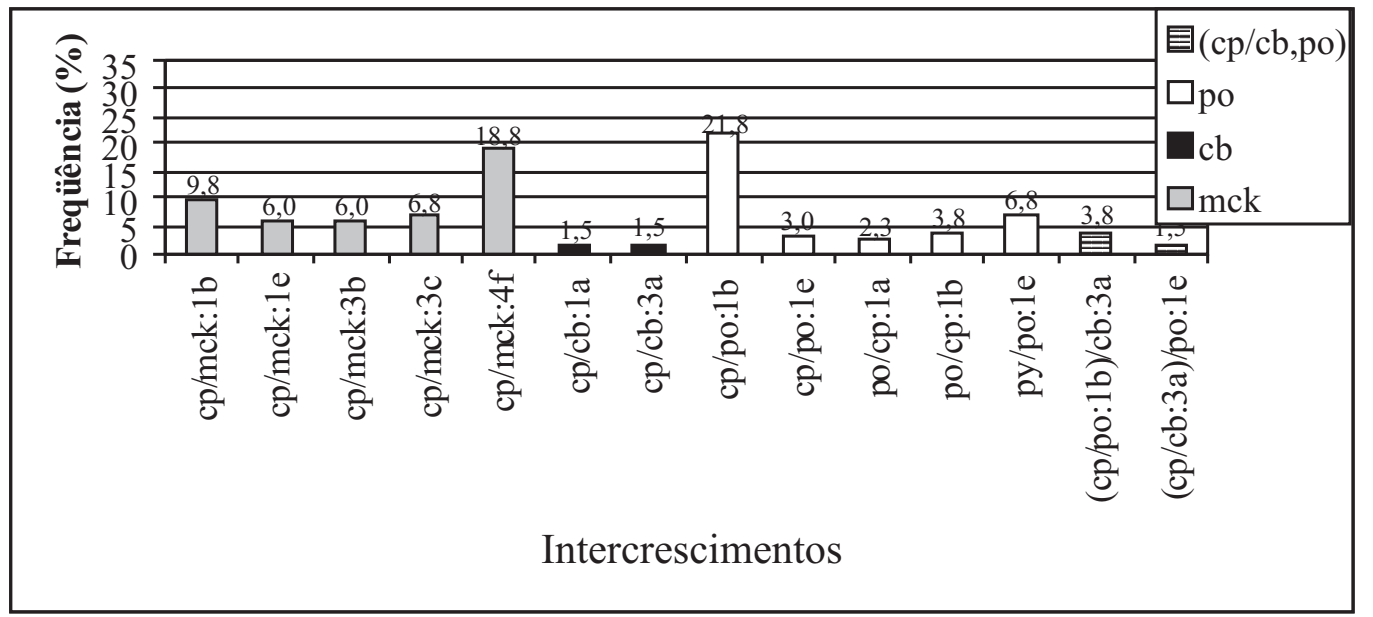

Figura 7.22: Freqüência comparativa dos intercrescimentos mais abundantes nas zonas de alteração fílica. 


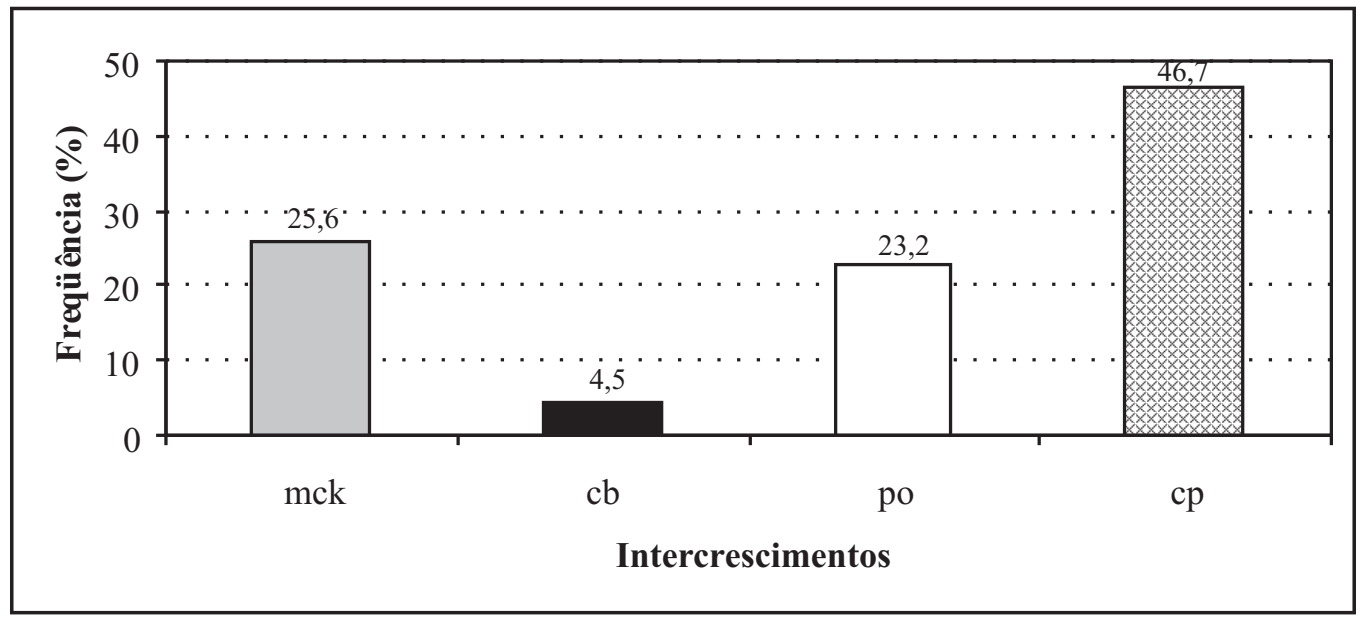

Figura 7.23: Freqüência comparativa dos intercrescimentos mais abundantes nas zonas de alteração fílica.

A freqüência relativa dos minerais nestas zonas mostra mackinawita, como mais importante $(25,6 \%)$, seguida pela pirrotita $(23,2 \%)$ e pela cubanita $(4,5 \%)$ (Figura 7.23 ). A comparação com as demais alterações com contribuições fílicas anteriores, mostra que a freqüência de cubanita aumenta e depois diminui levemente permanecendo os valores quase os mesmos. No caso da pirrotita a freqüência diminui e na mackinawita diminui e depois aumenta.

\subsection{Minerais que Constituem os Intercrescimentos}

Os resultados obtidos com o estudo ao microscópio, sob luz refletida, são sintetizados para cada amostra no Anexo 5, considerando as seguintes variáveis: tipo de alteração hidrotermal, mineralogia correspondente ao tipo de rocha, freqüência das fases sulfetadas típicas (pirrotita, cubanita e mackinawita) presentes nas inclusões, somadas ao número de inclusões computadas e as categorias estabelecidas na tabela 7.7. Também são incluídos outros minerais opacos identificados paralelamente ao estudo das inclusões.

No caso das alterações hidrotermais, as de tipo essencialmente potássica, propílica e fílica são as mais importantes, mas variedades intermédias entre estas também estão presentes e são consideradas e individualizadas por meio de uma barra inclinada. Existem também alguns casos em que dois tipos de alteração ocorrem em porcentagens semelhantes; neste caso, são separadas por um símbolo "=". Para descrever a intensidade da alteração foram usados os termos: forte (f), moderado (m), débil (d) e incipiente (i), conforme definidos no capítulo anterior.

No caso das inclusões sólidas, a análise apresentada no ítem anterior mostra que existe certa afinidade da presença e importância relativa de algumas fases com o tipo de alteração. Assim, foram considerados os dados relativos obtidos para pirrotita, cubanita e mackinawita, conforme detalhados a seguir: 
Pirrotita: foram encontradas inclusões com participação de pirrotita das 77 amostras estudadas em 47 foram encontradas inclusões com intercrescimentos nos quais este mineral participa, e destas, 23 amostras correspondem a zonas onde a alteração potássica participa com este mineral, 20 amostras em zona de alteração fílica e 4 em alteração propílica.

Assim, na zona de alteração potássica a pirrotita ocorre de forma ausente a traço, na zona de alteração potássica-propílica ocorre de ausente a pouco freqüente, propílica-potássica ocorre ausente a pouco freqüente predominando ausente-traço, potássica-propílica/fílica ocorre ausente a pouco freqüente, propílica ocorre ausente a traço predominando traço, propílicafílica ocorre ausente a traço, fílica-propílica ocorre ausente a escasso ocorrendo uma única vez freqüente e finalmente na fílica ausente a pouco freqüente predominando ausente-traço.

Cubanita: das 77 amostras estudadas em 24 foram encontrados inclusões com intercrescimentos no qual este mineral participa e destas 14 amostras corresponde às zonas onde a alteração fílica participa com este mineral, 6 amostras na zona de alteração propílica-potássica e 4 na potássica-propílica.

Desta forma na zona de alteração potássica a cubanita está ausente, na zona de alteração potássica-propílica ocorre de ausente a traço, propílica-potássica ocorre ausente a escasso predominando ausente, potássica-propílica/fílica ocorre ausente a escasso, propílica ocorre ausente, propílica-fílica ocorre ausente a traço predominando traço, fílica-propílica ocorre ausente a traço e na fílica ausente a traço predominando ausente.

Mackinawita: das 77 amostras estudadas em 48 foram encontrados inclusões com intercrescimentos no qual este mineral participa e destas 39 amostras corresponde às zonas onde a alteração propílica participa com este mineral, 8 amostras na zona de alteração fílica e 1 na potássica.

Assim, na zona de alteração potássica a mackinawita ocorre de forma ausente a traço, na zona de alteração potássica-propílica ocorre de ausente a escasso predominando traço, propílica-potássica ocorre ausente a escasso predominando traço seguido por ausente, potássicapropílica/fílica ocorre ausente a escasso, propílica ocorre ausente a escasso predominando ausente, propílica-fílica ocorre ausente a traço, fílica-propílica ocorre ausente a escasso ocorrendo uma única vez pouco freqüente, fílica ausente a escasso ocorrendo uma única vez pouco freqüente.

Os resultados permitiram esquematizar três perfis da jazida (Anexo 8) que relaciona os minerais que tipificam as inclusões com as alterações em profundidade.

Com base a estes resultados se confirma que a presença de pirrotita esta relacionada às zonas onde a alteração potássica está presente, a cubanita está relacionada com zonas de alteração fílica e mackinawita com zonas de alteração propílica. Assim tem-se que:

- Na zona de alteração potássica o mineral predominante é pirrotita. 
- Na zona de alteração potássica-propílica o mineral mais abundante é a pirrotita e menos abundante a mackinawita. Apesar de haver cubanita, ela é pouco expressiva.

- Na alteração propílica-potássica observa-se que a mackinawita aumenta em relação a anterior e a pirrotita e cubanita diminuem. A cubanita por sua vez representa $0,5 \%$ dos intercrescimentos, ou seja, com relação aos outros minerais é praticamente insignificante.

- Na alteração propílica o mineral de mackinawita é o mais abundante, a cubanita esta ausente e pirrotita diminui sensivelmente em relação as duas últimas onde a alteração propílica está presente.

- Na alteração potássica-propílica/fílica foi confirmada a presença dos três minerais esperados: pirrotita sendo o mineral mais abundante seguido pela mackinawita e cubanita menos abundante.

- Na alteração propílica-fílica comparada com a alteração anterior a mackinawita permanece constante, a pirrotita aumenta e a cubanita está ausente, no entanto quando se considera a freqüência deste mineral em todos os intercrescimentos estudados para esta alteração sua presença é confirmada (Figura 7.19).

- Na alteração fílica-propílica comparada com a alteração anterior a cubanita está presente e a mackinawita e pirrotita diminui.

- Na alteração fílica comparada com a alteração anterior o mineral de cubanita permanece constante a pirrotita diminui e a mackinawita aumenta.

Sendo assim, a pirrotita esta presente em todos os tipos de alterações, sendo sua maior abundância relacionada às zonas onde a alteração potássica está presente.

A cubanita ainda que não seja muito abundante é freqüente nas zonas onde a alteração fílica participa. Ela também é observada nas zonas de alteração potássica-propílica e propílicapotássica, no entanto quando comparada aos outros dois minerais sua presença é praticamente insignificante, nas zonas onde a alteração fílica participa sua representação não varia muito.

A mackinawita é mais abundante na zona de alteração propílica, na alteração potássica ainda esta presente justificada por ser produto dos primeiros indícios da alteração propílica. $\mathrm{Na}$ alteração propriamente fílica o mineral de mackinawita ocorre como o mineral mais abundante podendo ser produto de relíquias deixadas pela alteração propílica. 



\section{8 \\ Síntese, considerações finais e recomendações}

\subsection{Litologias e tipologia das alterações hidrotermais}

$\mathrm{Na}$ presente dissertação foram estudadas 77 amostras representativas de 22 furos de sondagem, cuja localização pode ser representada ao longo de três perfis principais ( $c f$. Capítulo 4, Figura 4.1). Nos parágrafos seguintes comentam-se as principais características observadas nestes perfís, comparando particularmente os resultados obtidos com os dados disponíveis nas seções geológicas da jazida Cuajone, disponibilizadas pela Southern Perú Copper Corporation.

\subsubsection{Perfil 1}

Este perfil localiza-se na região norte da jazida. Apresenta orientação E-W e foi elaborado a partir de sete furos de sondagem (Furos A a G). Petrograficamente, as rochas que caracterizam este perfil correspondem a andesitos (predominantes), quartzo latitos, pórfiros-II (micro tonalitos - micro leucoquartzo dioritos) e latitos (Figura 8.1)

Quartzo latitos ocorrem no lado W do perfil (amostras A-2 e A-3) entre as cotas 2993,92 e $3127,53 \mathrm{~m}$. No furo de sondagem D, as amostras foram classificadas originalmente como andesitos, entretanto, os nossos resultados, apesar das incertezas de classificação para diversas amostras ( cf. Capítulo 5), indicam que estas rochas (amostras D-1, cota 3299,23 m e, particularmente D-4, cota 3105,13 m) são melhor classificadas como micro tonalitos e/ou micro leuco quartzo dioritos (Pórfiros-II), particularmente considerando o seu caráter intrusivo. A amostra 


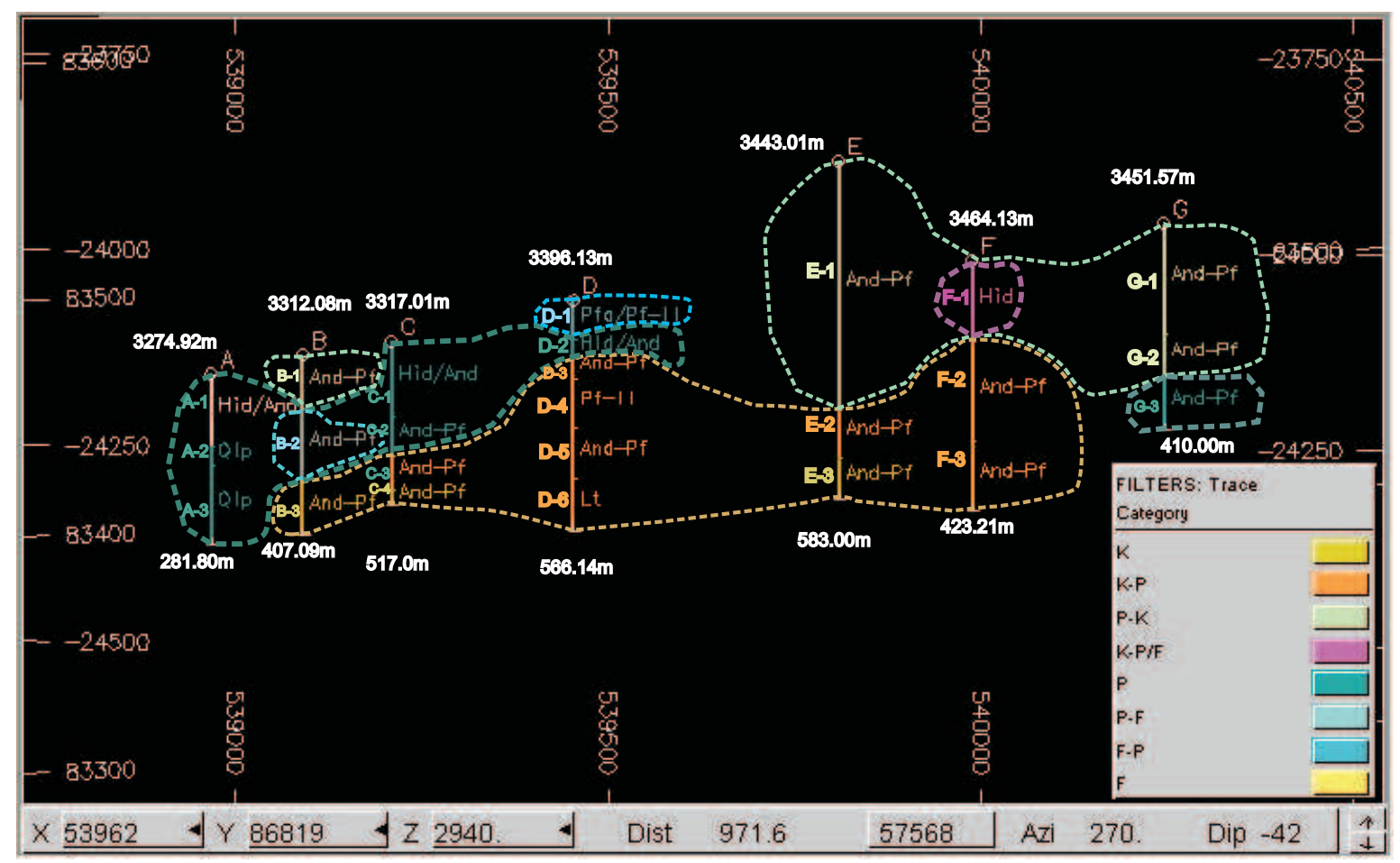

Figura 8.1: Localização do perfil 1 com seus respectivos furos de sondagem A-G indicando as rochas e os tipos de alteração hidrotermal presentes, representados com auxílio do programa Datamine. As cotas e profundidades são dadas na parte superior e inferior de cada furo respectivamente, as coordenadas são representadas em UTM. Ver o significado de abreviaturas dos tipos de rocha e alterações hidrotermais no Anexo 1.

D-6 (cota 2834,12 m) corresponde mais apropriadamente a um latito.

No furo F, representado pela amostra F-1 (cota 3356,03 m) a rocha presente pode ser caracteizada como um hidrotermalito, já que não é possível identificar parte significativa das características mineralógicas e texturais da rocha primária.

Os tipos de alterações hidrotermais identificadas neste perfil são potássica, potássica-propílica, propílica-potássica, potássica-propílica/fílica, propílica, propílica-fílica e fílica-propílica. Na zona interna do perfil observa-se o predomínio da alteração potássica, a qual grada para o exterior para zonas de alteração com participação propílica significativa. Apenas duas amostras apresentam alteração fílica, ainda assim combinada com a propílica, as quais se localizam para o lado W do perfil, nos furos de sondagem B (amostra B-2) e D (amostra D-1), nas cotas 3048,58 e $3299,23 \mathrm{~m}$ respectivamente.

É importante ressaltar que a alteração potássica no andesito está representada essencialmente pelo desenvolvimento de biotita hidrotermal, a qual é substituída por clorita nos níveis mais superiores, caracterizando uma alteração propílica. O feldspato potássico hidrotermal é quase ausente e ocorre apenas como finas venulações em algumas das amostras estudadas. O aumento de quartzo finamente granulado na matriz dos andesitos à medida que se caminha para os níveis superiores amostrados sugere um incremento no processo de silicificação, en- 
tretanto, como discutido, é muito difícil por vezes separar o quartzo intersticial primário do quartzo hidrotermal utilizando-se apenas de critérios petrográficos. Algumas amostras, com as características primárias quase que totalmente obliteradas, denominadas hidrotermalitos, apresentam resquícios mineralógicos e texturais que, aliados a sua localização nos furos e/ou perfíl sugerem que a rocha original tenha sido também andesítica.

A amostra D-6 (cota 2834,13 m), foi classificada como latito, uma vez que a parte importante do feldspato potássico identificada apresenta características que sugerem uma natureza primária. De fato, o feldspato potássico secundário nesta amostra aparece mais tipicamente na forma de venulações, associado com outros minerais hidrotermais.

Os micro tonalitos - micro leucoquartzo dioritos (Pórfiros-II) são afetados essencialmente pela alteração potássica-propílica. A alteração potássica é representada também pela presença de feldspato potássico em veios, às vezes acompanhado por quartzo, mas a biotita está tipicamente ausente, ao contrário do que ocorre nas rochas andesíticas. A única amostra representativa destas rochas neste perfil está localizada no furo de sondagem D (amostra D-4, cota $3105,13 \mathrm{~m}$ ). Vale à pena mencionar ainda que na cota 3299.23m (amostra D-1) foi encontrada uma rocha com alteração fílica-propílica intensa, cuja rocha original foi possivelmente um pórfiro-II.

\subsubsection{Perfil 2}

Este perfil foi elaborado a partir dos furos de sondagem H, I e J corresponde à zona centro-norte da jazida, com orientação NW-SE. As rochas presentes são: microgranodioritos e/ou microtonalitos porfiríticos no lado leste do perfil (amostras do furo de sondagem J), quartzo latitos na parte central (amostras do furo de sondagem I) e hidrotermalito, andesito, microbrecha e pórfiros-II no lado oeste (amostras do furo de sondagem H), (Figura 8.2).

Nos trabalhos originais relativos às amostras do furo de sondagem J, a exceção da amostra J3 (cota 2907,32 m), descrita como quartzo latito porfirítico-I, foram mapeadas como andesitos. As amostras estudadas na presente dissertação correspondem a hidrotermalitos (amostra J-1, cota 3400,82 m e amostra J-2, cota 3110,82 m), enquanto que na cota 2883,32 m (amostra J-4) aparece um pórfiro alterado. Em todos os casos é possível que as rochas originais tenham sido micro granodioritos e/ou micro tonalitos porfiríticos como a amostra J-3 (cota $2907.32 \mathrm{~m}$ ).

No furo de sondagem H, cota 3274,14 m (amostra H-1), andesitos foram descritos originalmente, mas a quantidade observada de feldspato potássico não corrobora esta classificação, nem como uma alteração típica de andesito. Dada a intensidade da alteração preferiu-se denominar a rocha como hidrotermalito. Nas cotas 3115,44 (amostra H-3) e 2945,14 m (amostra H-4) foram descritos latito porfiriticos-III, porém as análises petrográficas sugerem que os termos micro-brecha e micro tonalitos e/ou micro leucoquartzo dioritos sejam mais adequados.

As alterações presentes são: potássica, propílica-potássica, propílica-fílica, fílica-propílica e fílica. As alterações propílica-fílica e fílica-propílica ocorrem na zona mais interna do perfil, 


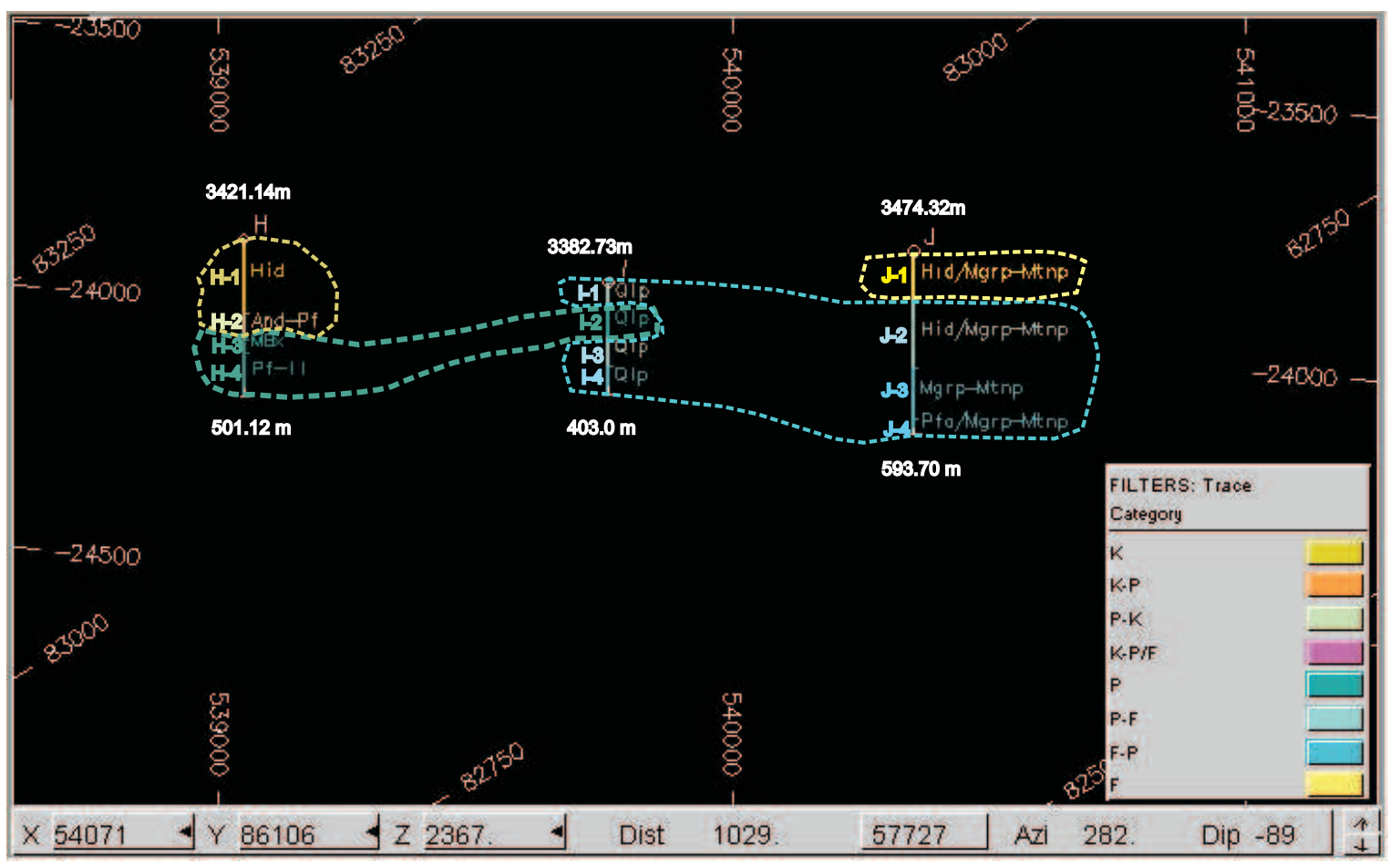

Figura 8.2: Localização do perfil 2 com seus respectivos furos de sondagem H, I e J indicando as rochas e os tipos de alteração hidrotermal presentes, representados com auxílio do programa Datamine. As cotas e profundidades são dadas na parte superior e inferior de cada furo respectivamente, as coordenadas são representadas em UTM. Ver o significado de abreviaturas dos tipos de rocha e alterações hidrotermais no Anexo 1.

enquanto que a alteração potássica está melhor marcada nas amostras correspondentes aos níveis com cotas superiores a 3274,14 e 3171,14 m (amostras H-1 e H-2) no lado W do perfil. A alteração fílica ocorre apenas no lado E, na cota $3400.82 \mathrm{~m}$ (amostra J-1).

\subsubsection{Perfil 3}

Este perfil corresponde à região sul da jazida, com orientação E-W e agrega 12 furos de sondagem. Este perfil é, de fato, o mais interessante por considerar um número significativo de furos de sondagem e maior variedade litológica, ocorrendo riolitos (as rochas mais abundantes do perfil), andesitos, andesitos-II, pórfiros-I, pórfiros-II, quartzo latitos porfiríticos, além de microtonalitos e/ou microgranodioritos porfiríticos.

O maior contraste entre os nossos resultados e os originais se refere à amostra K-3, na cota 3157,54 m, mapeado como andesito, mas cuja abundância de feldspato alcalino permite contrastá-lo dos andesitos mais típicos; por simplicidade foi denominado andesito-II. Diferenças menores são definidas para os furos de sondagem $\mathrm{O}, \mathrm{P}, \mathrm{Q}, \mathrm{R}, \mathrm{S}, \mathrm{T}$ e U nos quais com exceção do furo R, classificado como quartzo latito porfirítico-II, todos os demais são classificados como quartzo latito porfirítico-I.

Os resultados do estudo petrográfico indicam que as amostras O-1 (cota 3379,28 m) e Q- 
1 (cota 3204,83 m) descritas como pórfiro alterado e hidrotermalito respectivamente, sejam possivelmente originadas a partir de riolitos.

Neste trabalho micro tonalito porfirítico e andesito foram reconhecidos apenas no furo de sondagem $\mathrm{R}$ nas cotas $3031.56 \mathrm{~m}$ (amostra R-3) e $2739.29 \mathrm{~m}$ (amostra R-4) respectivamente. Micro-granodioritos porfiríticos foram descritos nos furos de sondagem S (amostra S-3, cota 2647,32 m) e T (T-2, cota 2883,92 e T-3, cota 2569,92 m). Pórfiros I (micro quartzo monzonitos - micro monzogranitos) aparecem nos furos P (amostras P-3, cota, 2758,07 e P-4 cota, 2746,07 m), Q (amostra Q-2, cota 3034,96 m), R (amostra R-1, cota $3189.89 \mathrm{~m}$ ) e S (amostra S1, cota $3151,32 \mathrm{~m}$ ). A amostra T-1 (cota 3232,92 m) foi classificada como pórfiro alterado, sendo possivelmente originada destas rochas. Depois dos riolitos, os micro tonalitos - micro leucoquartzo dioritos (Pórfiros-II) são as rochas mais abundantes, aparecem nas amostras O-2 (cota 3063,28 m), O-3 (cota 2800,28 m) P-2 (cota 2980,07 m), Q-3 (cota 2685,53 m), U-2 (cota $3092,76 \mathrm{~m})$ e U-3 (cota 2943,29 m). As amostras P-1 (cota $3088.07 \mathrm{~m})$, S-2(cota $2898.32 \mathrm{~m})$, T-1 (cota $3232.92 \mathrm{~m})$ e U-1(cota $3286.76 \mathrm{~m})$ são classificadas como pórfiros alterados, delas originados.

As alterações presentes neste perfil, das zonas interiores para os níveis superiores são: potássica-propílica, propílica-potássica, potássica-propílica/fílica, propílica, propílica-fílica, fílica-propílica e fílica, observando-se em geral uma distribuição gradativa do núcleo para o exterior com predomínio da alteração fílica no lado superior $\mathrm{W}$ do perfil. O fato de se encontrar uma zona de alteração propílica combinada com a potássica abaixo da zona de alteração fílica pode sugerir que esta zona corresponde à parte inferior lateral da jazida, junto aos limites entre as alterações propílica e potássica, conforme proposto no modelo original de Lowell \& Guilbert (1970), (cf. Capítulo 2).

Os riolitos são as rochas que se encontram mais afetadas pela alteração hidrotermal, especialmente de tipo fílica. Os Pórfiros -I e -II, bem como os micro-tonalitos e micro-granodioritos porfiríticos se apresentam menos alteradas, conservando ainda parte da textura e da mineralogia originais da rocha.

\subsection{Inclusões e intercrescimentos em fases sulfetadas}

Neste item serão discutidos aspectos relacionados às fases sulfetadas presentes sob a forma de intercrescimentos (inclusões) em pirita. Para tanto, considera-se, em especial os metais $\mathrm{Fe}, \mathrm{Cu}$, eventualmente Ni e Co, além do S. Merece ser destacado que, nas rochas originais, Fe é elemento essencial de magnetita, ilmenita e nos silicatos máficos (e.g., anfibólio, biotita). Concordo com Canchaya (com. pessoal) estes minerais, particularmente os óxidos, durante o processo de sulfidização são parcial e/ou completamente substituídos por pirita e sulfetos associados. O Ti presente em ilmenita e em quantidade menores na magnetita, é fase importante também na titanita primária, converte-se em rutilo e/ou leucoxênio (minerais freqüentes na categoria de outros minerais, tabela 7.8). 


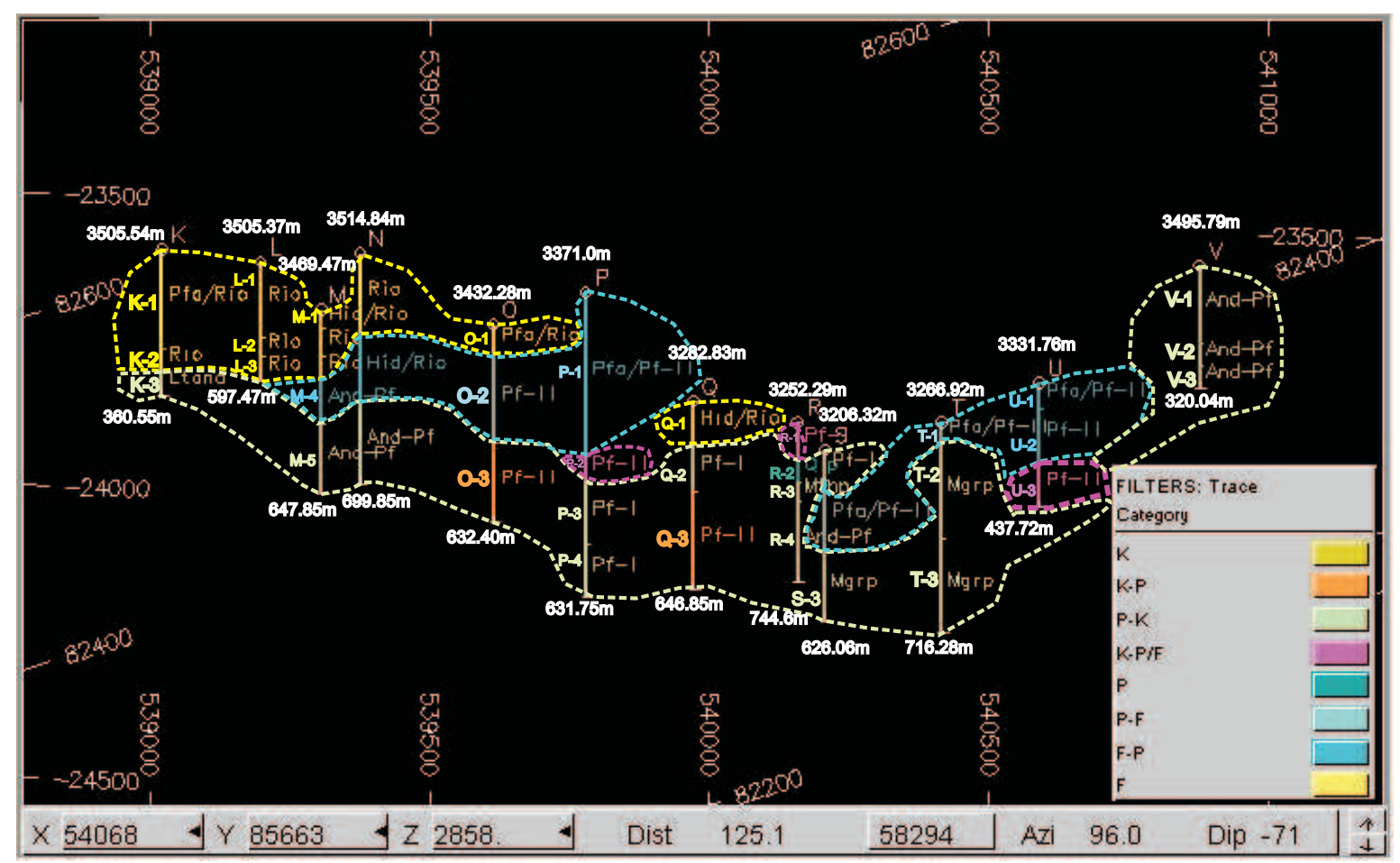

Figura 8.3: Localização do perfil 3 com seus respectivos furos de sondagem K-V indicando as rochas e os tipos de alteração hidrotermal presentes, representados com auxílio do programa Datamine. As cotas e profundidades são dadas na parte superior e inferior de cada furo respectivamente, as coordenadas são representadas em UTM. Ver o significado de abreviaturas dos tipos de rocha e alterações hidrotermais no Anexo 1.

Os campos de estabilidade das fases minerais portadoras de Fe e Ti são representados na Figura 8.4 em função das fugacidades das espécies voláteis $\mathrm{O}_{2}$ e $\mathrm{S}_{2}$. Esta Figura ilustra claramente os limites entre os campos de estabilidade das fases óxido e sulfeto. O diagrama apresenta que o aumento da fugacidade de $\mathrm{S}_{2}$, associado a um processo de sulfidização desestabiliza a magnetita e a ilmenita primárias e leva a formação de pirita e outros sulfetos portadores de Fe. Paralelamente, o aumento da fugacidade de $\mathrm{O}_{2}$ propicia a formação do rutilo, anatásio e leucoxênio (este ultimo não localizado na Figura), fases que concentram o Ti proveniente dos óxidos primários e da titanita. Representam-se também neste diagrama oito zonas hachuradas, as quais correspondem a oito assembléias minerais representativas de ocorrências típicas em diversos tipos de jazidas. As assembléias e alterações típicas de jazidas de tipo pórfiro são denominadas I, II, III. De acordo com os resultados obtidos por Canchaya (com. pessoal), os tipos mais freqüentes nas jazidas peruanas seriam II e III.

\subsubsection{Quimismo e seqüência de cristalização das fases minerais sulfetadas}

As composições químicas obtidas para pirita, calcopirita, pirrotita, cubanita, e mackinawita são muito próximas às composições ideais esperadas ( $c f$. Capítulo 7). Entre os elementos traços idenficados significativamente nas análises, merecem ser destacados: 


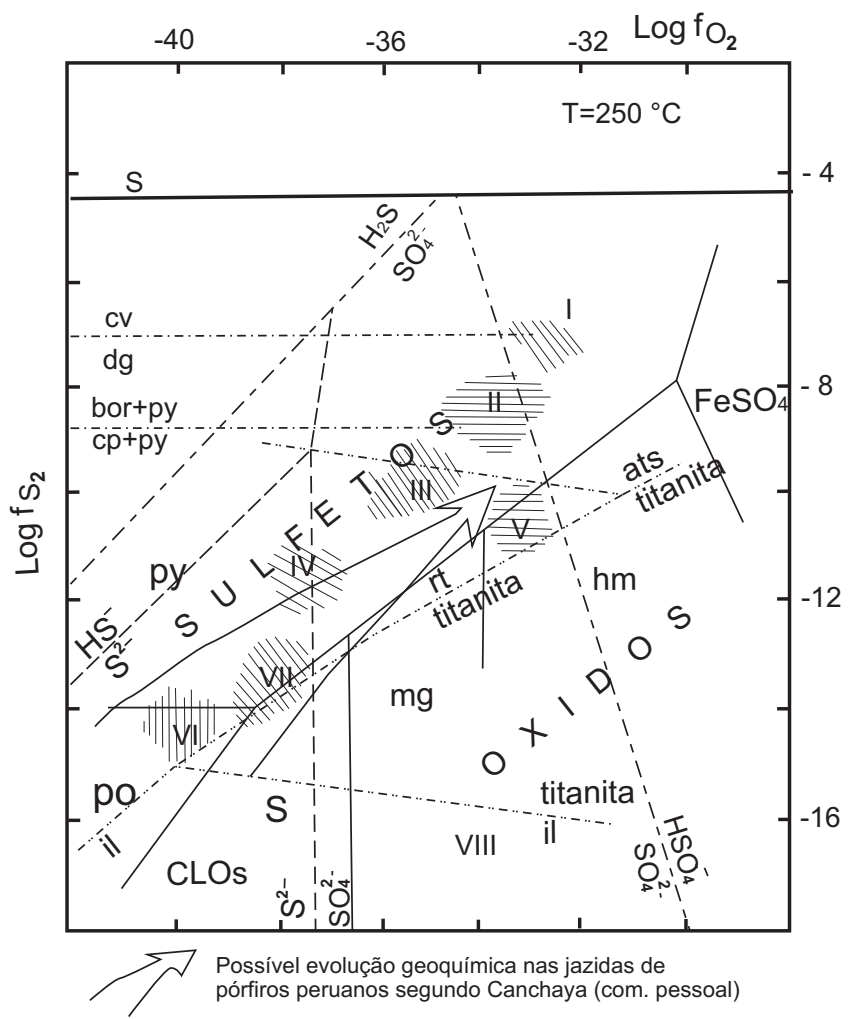

\begin{tabular}{|c|c|c|}
\hline ASSEMBLÉIA & ALTERAÇÃO OU GANGAS ASSOCIADAS & EXEMPLOS \\
\hline I. $\mathrm{cv}, \mathrm{dg}, \mathrm{cc}, \mathrm{py}$ & Argílica avançada mais alunita ou sericitização & Butte-Montana. \\
\hline II. $\quad c p, p y, b n(c c)$ & Sericítica e argílica intermediária a avançada & Butte-Montana. \\
\hline III. $c p, p y, m b$ & Potássica, sericitização ou argílica intermediária & $\begin{array}{l}\text { Butte-Montana, Toromocho, } \\
\text { Cerro Verde (zona central), } \\
\text { Quellaveco (zona central) }\end{array}$ \\
\hline IV. py, cp & $\begin{array}{l}\text { a) Silicificação } \\
\text { b) Anfibólios (escapolita) }\end{array}$ & $\begin{array}{l}\text { Tambogrande. } \\
\text { Raul Condestable, Cobre- } \\
\text { Acarí, Montarrosas. }\end{array}$ \\
\hline V. $\mathrm{cp}, \mathrm{hm},(\mathrm{py})$ & $\begin{array}{l}\text { a) Silicatos potássicos (anidrita, ankerita) } \\
\text { b) Sílice, carbonatos, outros }\end{array}$ & $\begin{array}{l}\text { Depósitos costa de Chile. } \\
\text { Cinco Cruz, Casa Blanca, } \\
\text { Mantos Huari pampa-Carahuacra }\end{array}$ \\
\hline VI. po, py, (cp) & Clorítização (sericítica, carbonatação): albitização & $\begin{array}{l}\text { Pipe de C. De Pasco, Los Mantos } \\
\text { (Hualgayoc). }\end{array}$ \\
\hline VII. po, py, cp, mg & Cloritização (sericitização, carbonatação) & Noranda, Chibougamon e Quebec. \\
\hline VIII. cu, cc, (hm), bn & Zeolitização, CLOs, FPs alcalinos, Carbonatação & Michigan. \\
\hline
\end{tabular}

Figura 8.4: Campos de estabilidade dos principais sulfetos (Craig \& Scott, 1974), óxidos de ferro Meyer \& Hemley (1967) e Ti (Udubasa, 1982) no diagrama $f_{O 2}$ vs. $f_{S 2}$. A tabela anexada na parte inferior da Figura corresponde às zonas hachuradas do gráfico de acordo com Meyer \& Hemley (1967), onde se apresentam as assembléias de minerais opacos características associadas às alterações e exemplos de jazidas típicas. Ver significado de abreviaturas dos minerais no Anexo 1.

- $\mathrm{Cu}, \mathrm{Au}$ e Ni, em pirita, o primeiro em amostras das zonas de alteração potássica-propílica, propílica-potássica, potássica-propílica/fílica e fílica-propílica, o segundo em uma amostra da zona de alteração potássica-propílica e fílica-propílica e o terceiro elemento em uma amostra da zona de alteração propílica-potássica;

- Zn e Au em calcopirita nas zonas de alteração potássica-propílica e fílica-propílica e só Au em potássica-propílica/fílica; 
- Zn e Ag na cubanita, o primeiro em quantidades significativas, o segundo em quantidades menores nas zonas de alteração propílica-potássica e Au e Zn nas zonas fílica-propílica;

- Cu sempre em quantidades significativas em pirrotita, Zn em abundâncias menores nas zonas de alteração potássica-propílica/fílica, propílica-potássica e fílica-propílica, e Au presente em pequenas quantidades em apenas uma amostra de zona fílica-propílica;

- $\mathrm{Cu}, \mathrm{Zn}$ e $\mathrm{Au}$ em quantidades significativas e Ni e Ag em quantidades menores na mackinawita das zonas de alteração potássica-propílica e propílica-potássica.

As observações texturais e micro-estruturais, aliadas às informações extraídas do diagrama apresentado na Figura 8.4., permitem elaborar, pelo menos tentativamente, uma seqüência de cristalização das fases sulfetadas, a qual é representada esquematicamente na Figura 8.5. Nesta Figura, as fases primárias magnetita e ilmenita, principais portadoras de Fe e Ti também são incluídas, apesar de não terem sido estudadas especificamente. Não se representam também as fases associadas aos eventos posteriores de enriquecimento secundário, geradas em ambientes mais fortemente oxidantes, as quais não estiveram entre os objetivos da dissertação.

A interpretação mais simples é que as soluções hidrotermais com atividades de $\mathrm{S}_{2}$ relativamente elevadas inicialmente levam à desestabilização das principais fases minerais portadoras de elementos como $\mathrm{Fe}, \mathrm{Cu}, \mathrm{Zn}$ e Ni (e.g. Naldrett \& Kullerud, 1966) e a sua reprecipitação em fases sulfetadas, na seguinte ordem: primeiro com a formação de pirita, após calcopirita, pirrotita, cubanita e mackinawita. A fase cuprífera é fechada pela estabilização da cubanita. A formação de rutilo-leucoxênio estaria associada ao paralelo aumento na fugacidade de oxigênio e desestabilização de fases ferromagnesianas e acessórios primários, particularmente titanita. Neste esquema, a localização da molibdenita é apenas tentativa.

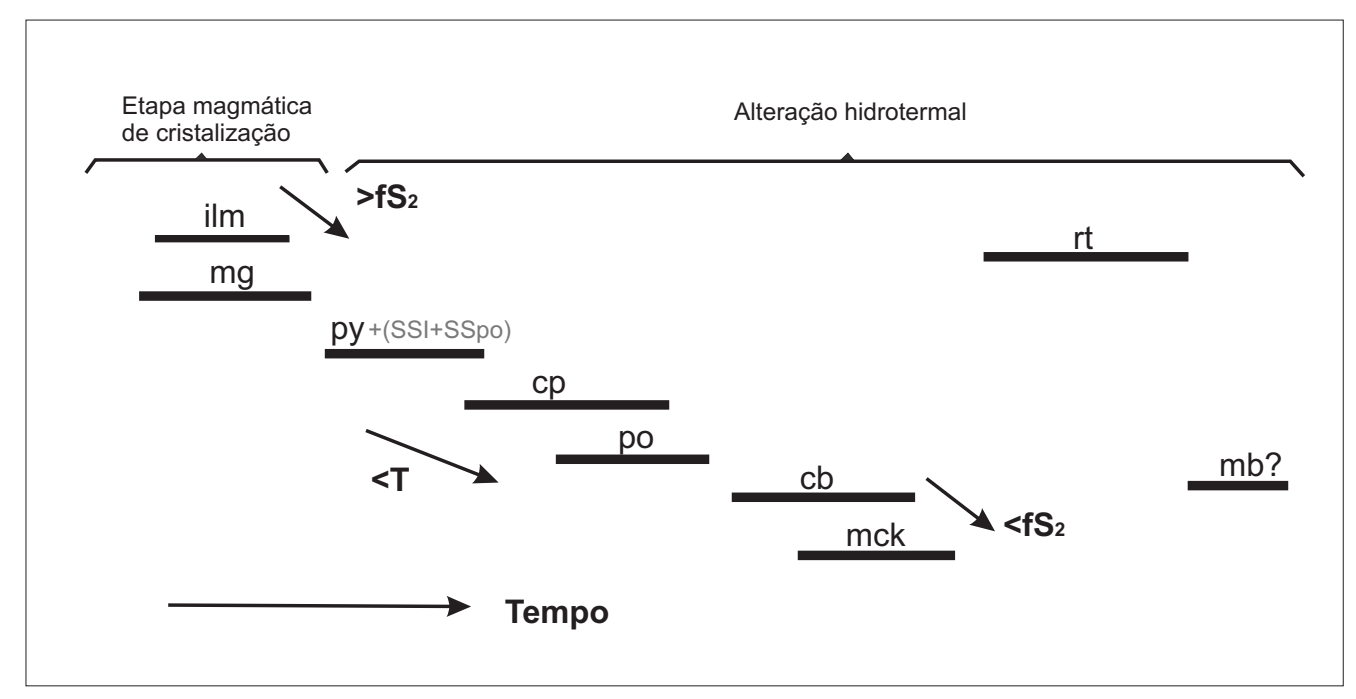

Figura 8.5: Diagrama da possível seqüência de cristalização dos minerais estudados em função da fugacidade de $\mathrm{S}_{2}$. Ver significado de abreviaturas dos minerais no Anexo 1. 


\subsubsection{Relações de fase no sistema Cu-Fe-S}

O estudo das relações de fase no sistema $\mathrm{Cu}-\mathrm{Fe}-\mathrm{S}$, de grande interesse em metalogênese, foi iniciado há mais de seis décadas, com a contribuição de Merwin \& Lombard (1937). Bartholomé (1958) e MacKinstry (1959) mostraram uma comparação das assembléias em depósitos minerais com os dados experimentais disponíveis à época e acentuaram as incertezas nas relações de fase conhecidas, especialmente em temperaturas inferiores a $500{ }^{\circ} \mathrm{C}$.

Nas décadas de 60 e 70, Yund \& Kullerud (1966) determinaram as relações de fase neste sistema sob temperaturas entre $700{ }^{\circ} \mathrm{C}$ e ca. $200{ }^{\circ} \mathrm{C}$. Mukaiyama \& Izawa (1970) estudaram as relações de fase na parte mais pobre em $\mathrm{Cu}$ em temperaturas entre 300 e $575{ }^{\circ} \mathrm{C}$ e entre 200 e $300{ }^{\circ} \mathrm{C}$ e determinaram a estabilidade termal da fase de transição da pirrotita, calcopirita e cubanita em ambientes hidrotermais. Cabri (1973) estudou o sistema a temperaturas entre 100 e $600{ }^{\circ} \mathrm{C}$ e Sugaki et al. (1975) estudou o sistema em condições hidrotermais, entre 350 e $300{ }^{\circ} \mathrm{C}$.

Mais recentemente, Amcoff (1981) realizou aquecimento em calcopirita e pirrotita e estudou a estabilidade da solução sólida intermediária. Paralelamente, Kojima \& Sugaki (1984) estudaram as relações de fase na porção central do sistema quaternário Cu-Fe-Zn-S entre 800 e $500{ }^{\circ} \mathrm{C}$ e, posteriormente, sob condições hidrotermais, entre 300 e $500{ }^{\circ} \mathrm{C}$ (Kojima \& Sugaki, 1985). Lusk et al. (1993) estudaram as relações de fase no sistema Fe-Zn-S em temperaturas entre 325 e $150{ }^{\circ} \mathrm{C}$ e, finalmente, Lusk \& Bray (2002) apresentaram novos resultados para os sistemas Cu-Fe-S e Fe-S a 1 bar e temperaturas entre 185 e $460{ }^{\circ} \mathrm{C}$.

A pesar destas investigações e da quantidade de informações acumuladas para as fases sulfetadas no diagrama $\mathrm{Cu}-\mathrm{Fe}-\mathrm{S}$, parte das relações de fase ainda são enigmáticas, particularmente nas temperaturas mais baixas, devido ao grande numero de fases presentes, às extensivas soluções sólidas possíveis e às dificuldades para se alcançar o equilíbrio durante os experimentos e conseqüente formação de fases meta-estáveis.

Estes trabalhos experimentais mostram que existem, essencialmente, três tipos de soluções sólidas a altas temperaturas no sistema $\mathrm{Cu}-\mathrm{Fe}-\mathrm{S}$ (Figura 8.6): solução sólida intermediaria (SSI), solução sólida de bornita (SSbor), solução sólida de pirrotita (SSpo). Uma solução sólida de calcopirita (SScp) é gerada a partir da SSI com diminuição de temperatura.

Os minerais sulfetados presentes em Cuajone, são, a exeção da calcopirita, relativamente pobres em $\mathrm{Cu}$ e ricos em $\mathrm{Fe}$, portanto a parte de maior interesse no diagrama corresponde à porção central direita. As relações de fases encontradas à medida que a temperatura decai envolvem solução sólida intermediaria (SSI), solução sólida de pirrotita (SSpo), solução sólida de calcopirita (SScp) a partir das quais são gerados calcopirita, pirrotita, cubanita e mackinawita. A evolução dos conhecimentos no diagrama $\mathrm{Cu}-\mathrm{Fe}-\mathrm{S}$ e as transições entre as fases de interesse para a dissertação são apresentados e discutidos a seguir.

Solução sólida intermediaria (SSI, cf. Merwin \& Lombard, 1937) corresponde a uma solução sólida extensiva localizada perto da porção central do sistema $\mathrm{Cu}-\mathrm{Fe}-\mathrm{S}$, de simetria 


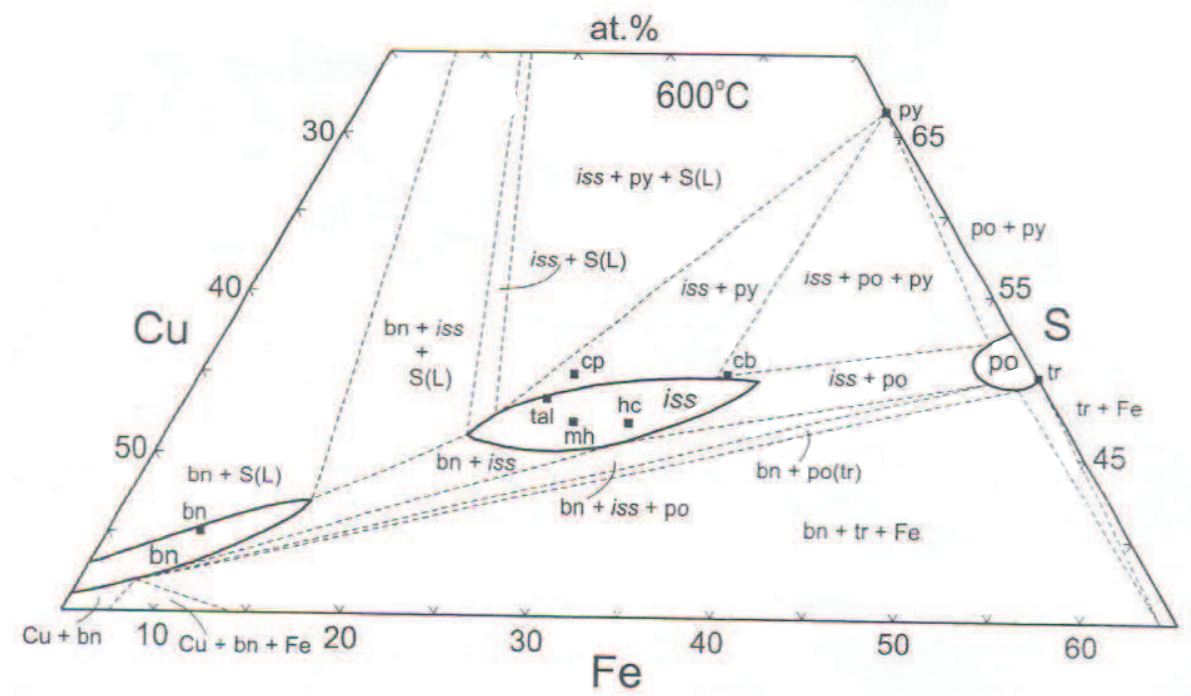

Figura 8.6: Relações de fase na porção central do sistema Fe-Cu-S a $600{ }^{\circ} \mathrm{C}$. Nesta temperatura são observados três campos extensos de solução solida: bornita (bn ou SSbor), solução sólida intermediaria (iss ou SSI) e pirrotita (po ou SSpo). Em temperaturas inferiores, gera-se uma solução sólida de calcopirita (SScp) a partir do desmembramento da SSI. Ver Anexo 1 para as abreviaturas. Fonte: Fleet (2006).

cúbica, com estrutura similar a da esfalerita. É estável em temperaturas mais altas e instável sob condições ambientais Cabri (1973). Yund \& Kullerud (1966) acreditam que esta fase corresponda a uma solução sólida de cubanita. Posteriormente, esta denominação foi utilizada por Mukaiyama \& Izawa (1970), Cabri (1973), Barton (1973) e Amcoff (1981) para distinguí-la da calcopirita típica, de simetria tetragonal.

Segundo os trabalhos realizados por Sugaki et al. (1975) e Kojima \& Sugaki $(1984,1985)$ a solução sólida intermediaria estende-se para composições que correspondem estequiométricamente à cubanita, e para uma fase mais rica em Cu e deficiente em $\mathrm{S}$ (denominada mooihoekita, $\mathrm{mh}$ ), em temperaturas de $350{ }^{\circ} \mathrm{C}$ e $700-600{ }^{\circ} \mathrm{C}$ respectivamente. Estes resultados são concordantes com os dados de Yund \& Kullerud (1966) para $700{ }^{\circ} \mathrm{C}$, Mukaiyama \& Izawa (1970) para $525{ }^{\circ} \mathrm{C}$ e Barton (1973) para $600{ }^{\circ} \mathrm{C}$, com exceção de que, no estudo de Mukaiyama \& Izawa (1970), a composição da cubanita cai dentro do campo de solução sólida intermediaria (SSI).

Sugaki et al. (1975) assinalam que a SSI coexiste estavelmente com pirita, pirrotita, solução sólida de calcopirita (SScp) e solução sólida de bornita (SSbor) a $350{ }^{\circ} \mathrm{C}$. Kojima \& Sugaki (1984, 1985) observaram em suas investigações que o comportamento da SSI, com incorporação de Zn, é muito semelhante à do sistema Cu-Fe-S livre de Zn. Em seus experimentos a 500 e 300 ${ }^{\circ} \mathrm{C}$ sob condições hidrotermais observaram que o campo de SSI no sistema quaternário muda com a pressão e a temperatura, observando que as variações composicionais ficam progressivamente mais restritas com a diminuição da temperatura, mas o teor em $\mathrm{Cu}$ possível na solução sólida aumenta com o aumento da pressão.

Solução sólida de calcopirita (SScp) Os primeiros trabalhos sugeriam que a calcopirita 
seria formada diretamente a partir a exolução da (SSI) sob alta temperatura, mas os dados de MacLean et al. (1972), Barton (1973) e Cabri (1973) mostraram a seguir que a calcopirita quebra para SSI + pirita + vapor.

Sugaki et al. (1975) mostraram que sob condições hidrotermais a 350 e $300{ }^{\circ} \mathrm{C}$, a calcopirita apresenta solução solida (SScp) que se estende desde uma composição quase estequiométrica $\mathrm{CuFeS}_{2}$ para uma composição levemente rica em ferro. A $300{ }^{\circ} \mathrm{C}$ o campo de SScp é algo reduzido. Amcoff (1981) observou que abaixo de $590{ }^{\circ} \mathrm{C}$ a SSI quebra em uma fase rica em $\mathrm{Cu}$ e outra rica em Fe. Abaixo de $540{ }^{\circ} \mathrm{C}$ aparece a calcopirita tetragonal na porção rica em $\mathrm{Cu}$. Segundo Pankratz \& King (1970) esta fase tetragonal é separada da fase cúbica de SSI a $557{ }^{\circ} \mathrm{C}$, enquanto que para Yund \& Kullerud (1966) esta transição aconteceria a $547 \pm 5$ ${ }^{\circ} \mathrm{C}$. Kojima \& Sugaki $(1984,1985)$ mostram que a $500{ }^{\circ} \mathrm{C}$ a calcopirita apresenta um pequeno campo de solução solida e que a solubilidade de Zn na SScp é geralmente baixa e diminui com a temperatura.

Cubanita, Isocubanita (cb,Icb) Yund \& Kullerud (1966) em seus experimentos de quenching mostram que cubanita em presença de vapor é cúbica (SSI) acima de $252 \pm 3$ ${ }^{\circ} \mathrm{C}$; abaixo desta temperatura e até $213{ }^{\circ} \mathrm{C}$, a cubanita apresenta simetria tetragonal e abaixo de $213{ }^{\circ} \mathrm{C}$ torna-se ortorrômbica. Mukaiyama \& Izawa (1970) observaram que a cubanita ortorrômbica é transformada na fase cúbica de alta temperatura a 200 e $235^{\circ} \mathrm{C}$, a fase tetragonal não foi observada em seus experimentos. Estes autores mencionam também que a cubanita tratada hidrotermalmente permanece ortorrômbica até $200{ }^{\circ} \mathrm{C}$, trocando para simetria cúbica somente a $250{ }^{\circ} \mathrm{C}$. Cabri (1973) concluem que a passagem da simetria ortorrômbica para cúbica ocorre entre 200 e $210{ }^{\circ} \mathrm{C}$. Resultados de Kaneda et al. (1978) e, em parte, Borchert (1934), com experimentos de aquecimento, mostram a cubanita se decompõe em duas fases: calcopirita e calcopirrotita, sob ca. $215^{\circ}-235^{\circ} \mathrm{C}$.

A calcopirrotita foi reportada por Ramdohr (1969) como uma das duas ocorrências de cubanita (ortorrômbica e isotrópica ou cubanita de alta temperatura, de simetria cúbica). A cubanita de alta temperatura foi encontrada na mina Kavelotorp Sweden e denominada calcopirrotita. Caye et al. (1988) propõem que o polimorfo cúbico de cubanita, calcopirrotita, denominado anteriormente como cubanita cúbica, cubanita-II ou cubanita de alta temperatura seja definido como Isocubanita, termo aprovado pelo IMA. Estes autores reconhecem que este polimorfo é instável, que a sua temperatura de formação seja maior de $200{ }^{\circ} \mathrm{C}$ e que geralmente ocorra intercrescida com calcopirita rica em Fe e Zn.

Solução sólida de pirrotita (SSpo) Esta solução é extensiva no sistema ternário sob altas temperaturas, mas esta extensão diminui rapidamente em direção a aresta Fe-S no sistema binário $\mathrm{FeS}$ e $\mathrm{FeS}_{2}$ por diminuição da temperatura. De fato, solubilidades de $\mathrm{Cu}$ (\% em peso) da ordem de 4,5\%,2 \%, 0,6\% e 0,3\% foram determinadas experimentalmente sob temperaturas de 700, 600, 350 e $300{ }^{\circ} \mathrm{C}$, respectivamente (Yund \& Kullerud, 1966; Gehlen \& Kullerud, 1962; Sugaki et al., 1975). Sob temperaturas da ordem de $300{ }^{\circ} \mathrm{C}$, a pirrotita aparece nas fases hexagonal e monoclínica. Kojima \& Sugaki $(1984,1985)$ indicam que a fase hexagonal dissolve 
$3,5 \%$ atômico de $\mathrm{Cu}$ a $800{ }^{\circ} \mathrm{C}$ e $1,8 \%$ atômico a $500{ }^{\circ} \mathrm{C}$. Concordam que a fase hexagonal é estável e que a pirrotita monoclínica é instável ainda a $300{ }^{\circ} \mathrm{C}$, como reportado por Sugaki et al. (1975) e Kissin \& Scott (1982). Segundo Kaneda et al. (1978) a pirrotita monoclínica apareceria somente sob temperaturas inferiores a $250{ }^{\circ} \mathrm{C}$. Lusk et al. (1993) mostram que no sistema Fe-Zn-S a pirrotita monoclínica pode ser estável a $c a .140{ }^{\circ} \mathrm{C}$.

Mackinawita Este mineral assim com pirrotita não é considerado dentro do sistema ternário $\mathrm{Cu}-\mathrm{Fe}-\mathrm{S}$, mas é uma fase relevante no sistema binário Fe-S a baixa temperatura. As relações de fase neste sistema são complexas e pouco compreendidas devido à inconsistência entre produtos de laboratório e assembléias naturais, sendo que estas últimas refletem melhor as estabilidades minerais. A mackinawita esta incluída no grupo de minerais que podem ser meta-estáveis ou, pelo menos, de estabilidade questionável Lennie \& Vaughan (1996). Em espécies naturais, a estabilidade termal da mackinawita, admitida como estável em temperaturas inferiores a $135{ }^{\circ} \mathrm{C}$ a partir de deduções com base em estudos microscópicos parece ser dependente da substituição de Ni ou Co por Fe (Clark, 1966). De acordo com Zoka et al. (1972) as temperaturas de quebra da mackinawita natural estariam entre 128 e $139{ }^{\circ} \mathrm{C}$, mas o processo não seria isoquímico, mas sim envolveria adição de $\mathrm{S}$ de fases coexistentes. Entretanto, Kouvo \& Vuorelainen (1963) sugerem que a transformação direta de mackinawita para pirrotita hexagonal ocorreria em temperatura de $169{ }^{\circ} \mathrm{C}$. Lennie et al. (1995a) obtiveram experimentalmente pirrotita hexagonal por simples aquecimento de mackinawita entre 173 e $178^{\circ} \mathrm{C}$.

\subsubsection{Intercrescimentos mais importantes entre calcopirita, pirrotita, cubanita e mackinawita}

As morfologias mais típicas dos diferentes intercrescimentos encontrados como inclusões em pirita na jazida de Cuajone caracterizadas opticamente e/ou em mapas composicionais são representadas diagramaticamente no diagrama quaternário calcopirita-cubanita-pirrotitamackinawita da Figura 8.7 para melhor visualização.

Neste diagrama, observa-se que não se apresentam intercrescimentos envolvendo cubanita e mackinawita, mas eles estão presentes na categoria dos intercrescimentos menos freqüentes do Anexo 7. Merece ser destacado que a pesar de que os minerais estudados tenham sido originados de distinta composição de soluções solidas assim como temperaturas de formação eles ocorrem intercrescidos.

\section{Geração dos principais intercrescimentos}

$\mathrm{O}$ estudo das relações entre as fases no sistema $\mathrm{Cu}-\mathrm{Fe}-\mathrm{S}$ necessariamente deve ser embasado em resultados experimentais ( $c f$. item 8.2.2. acima). Na Figura 8.8 são apresentados diagramas de fase neste sistema para temperaturas no intervalo entre $600-25{ }^{\circ} \mathrm{C}$ (ambiente). Destacam-se as áreas relevantes que envolvem os minerais identificados, localizadas nas regiões relativamente 


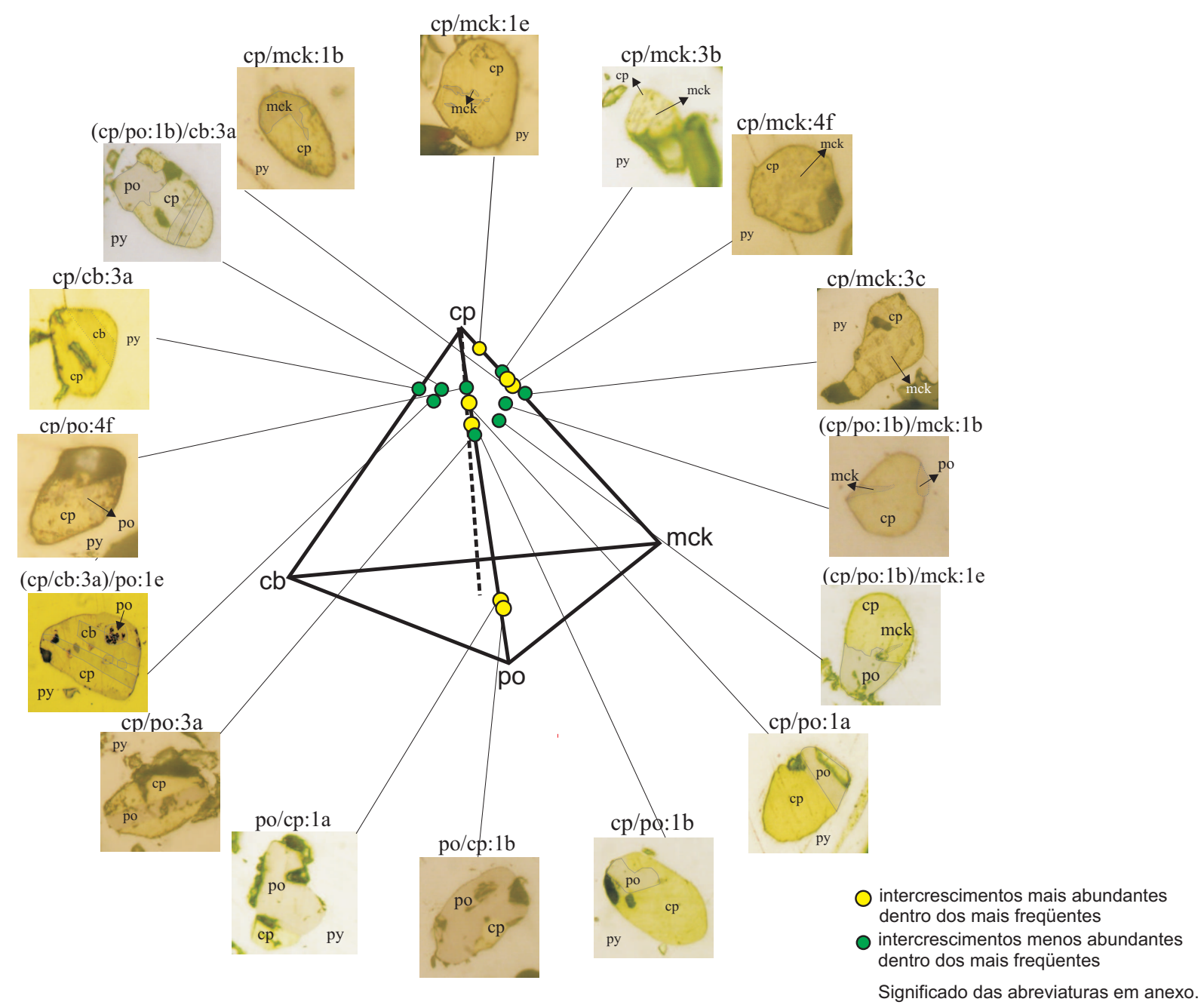

Figura 8.7: Diagrama quaternário calcopirita-cubanita-pirrotita-mackinawita ilustrando os tipos de intercrescimentos mais freqüentes descritos para a jazida de Cuajone. Os pontos são posicionados qualitativamente no diagrama. Abreviaturas representadas no Anexo 1.

pobres em Cu do diagrama, compiladas a partir dos trabalhos de Fleet (2006), Amcoff (1981), Vaughan \& Craig (1978), Kaneda et al. (1978), Cabri (1973), Mukaiyama \& Izawa (1970), Sugaki et al. (1975), Yund \& Kullerud (1966).

Os dados experimentais indicam que a temperaturas superiores a $600{ }^{\circ} \mathrm{C}$ tem-se uma assembléia de SSI + py + SSpo (Yund \& Kullerud, 1966; Mukaiyama \& Izawa, 1970; Cabri, 1973; Barton, 1973; Amcoff, 1981) e sob temperaturas inferiores a $590^{\circ} \mathrm{C}$, a SScp é separada da SSI. O diagrama a $300{ }^{\circ} \mathrm{C}$ mostra que a "tie line" SSI-py, estável a $350{ }^{\circ} \mathrm{C}$, é substituída por SScp-po na temperatura de $328 \pm 5{ }^{\circ} \mathrm{C}$ (Yund \& Kullerud, 1966) ou $335{ }^{\circ} \mathrm{C}$ (Lusk \& Bray, 2002). Em $250{ }^{\circ} \mathrm{C}$ a SSI desaparece e aparece SSicb (para Caye et al., 1988, maior a $200{ }^{\circ} \mathrm{C}$ ) em equilíbrio com SScp e pirrotita. A $180{ }^{\circ} \mathrm{C}$ a cubanita seria gerada a partir da SSicb, em presença de mackinawita e de pirrotita hexagonal e monoclínica. Em temperatura de $25{ }^{\circ} \mathrm{C}$ (Kaneda et al., 1978), aparecem moohoekite (mh), haycokite (hc), talnakite (tlk), calcopirita, 
pirrotita (hexagonal e monoclínica), cubanita e mackinawita. Os três primeiros seriam gerados a partir da SSI com composições similares a da calcopirita.

\section{Geração das assembléias simples}

Os resultados obtidos permitem aprofundar as interpretações preliminares de Canchaya (com. pessoal) as quais são descritas a seguir:

\section{Intercrescimento entre pirita /pirrotita: 1e}

Estes intercrescimentos podem ser originados a partir de dois mecanismos (c.f. Hagel, 1994). O primeiro mecanismo advoga que a pirita substituiria a pirrotita devido a um incremento na $\mathrm{fS}_{2}$, através de uma reação simples de tipo:

$$
\mathrm{Fe}_{(1-\mathrm{X})} \mathrm{S}+\mathrm{S}_{(1-2 \mathrm{X})}=\mathrm{Fe}_{(1-\mathrm{X})} \mathrm{S}_{2 \cdot(1-\mathrm{X})}
$$

O segundo mecanismo possível seria a exsolução de pirrotita a partir de uma solução sólida de pirrrotita em equilibrio meta-estável com pirita, a qual teria se gerado a partir da assembléia SSI + py + SSpo, estável a $350^{\circ} \mathrm{C}$. Ao descer a temperatura, a "tie line" SSI-py é substituída por SScp-po, sob temperaturas entre ca. 323 e $335{ }^{\circ} \mathrm{C}$. Em $300{ }^{\circ} \mathrm{C}$, a assembléia estável seria: SScp+SSI+po. De forma diagramática, uma possível interpretação seria a seguinte:

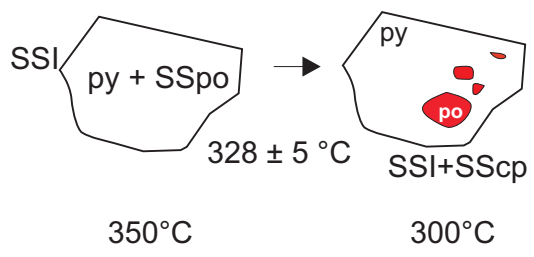

\section{Intercrescimentos entre calcopirita-cubanita}

Este tipo de intercrescimento seria originado a partir de soluções comparativamente ricas em $\mathrm{Cu}$ e pobres em Fe em relação ao tipo anterior. A $300{ }^{\circ} \mathrm{C}$ a assembléia seria SScp + SSI em desequilíbrio com pirita. Ao descer a temperatura, a assembléia teria sido: SScp + SSicb a 235 e $210{ }^{\circ} \mathrm{C}$ segundo Borchert (1934) e Kaneda et al. (1978) respectivamente. Quando a temperatura desce, forma-se calcopirita a partir da solução sólida de calcopirita (SScp) e, posteriormente, abaixo de $235{ }^{\circ} \mathrm{C}$ se forma cubanita (Mukaiyama \& Izawa, 1970)) em forma de lamelas de exsolução (3a) ou em intercrescimentos de contornos retos (1a) ou ameboidais (1b) com calcopirita. Para Yund \& Kullerud (1966) a cubanita apareceria em temperaturas inferiores a $252 \pm 3{ }^{\circ} \mathrm{C}$. Graficamente poderia ser representado assim: 

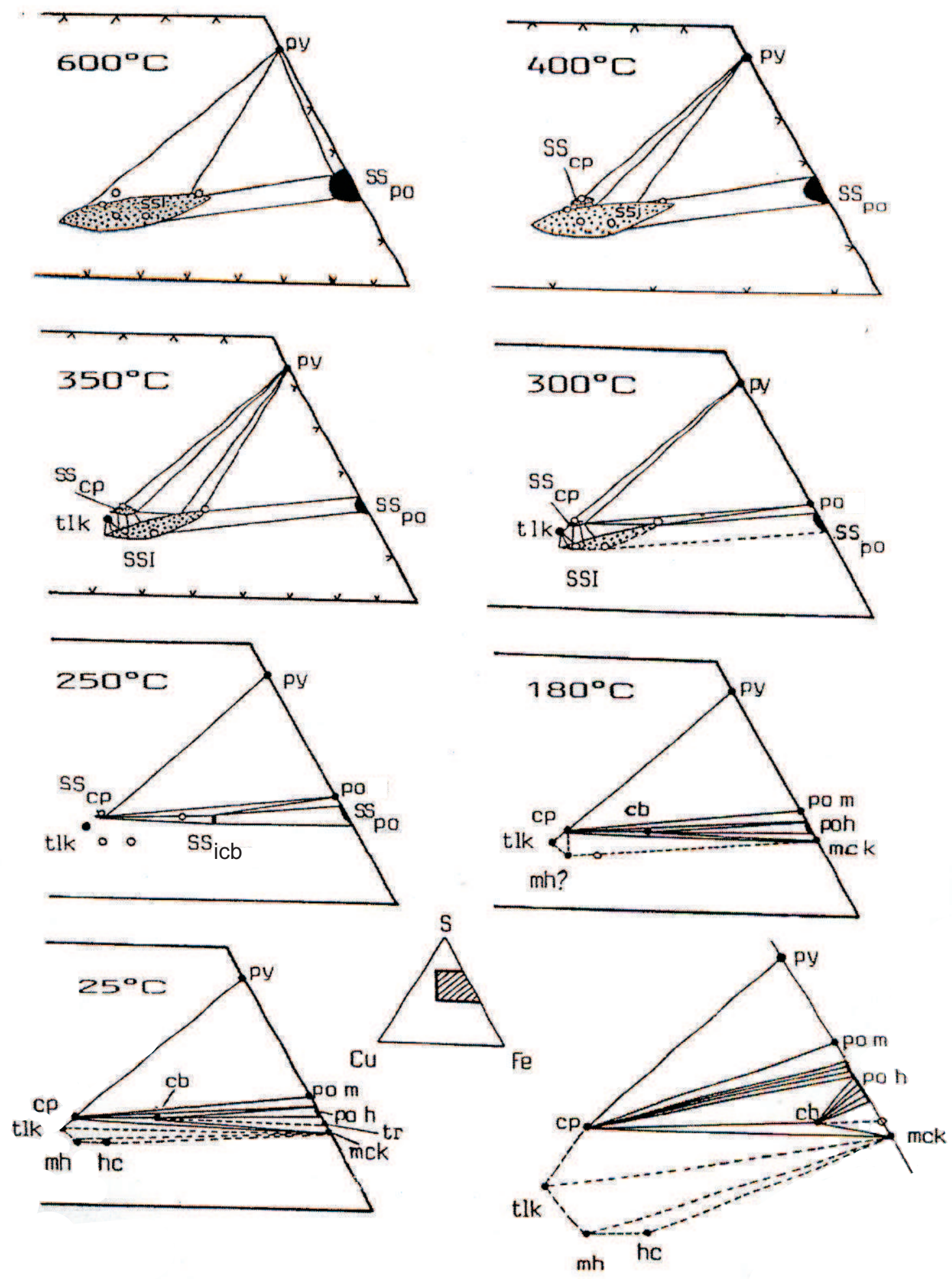

Figura 8.8: Relação de fases para diferentes temperaturas entre os minerais que aparecem como inclusões sólidas em pirita na jazida Cuajone. SSI = solução sólida intermediária, SSpo = solução sólida de pirrotita, SScp = solução sólida de calcopirita. Abreviaturas dos minerais no Anexo 1. 


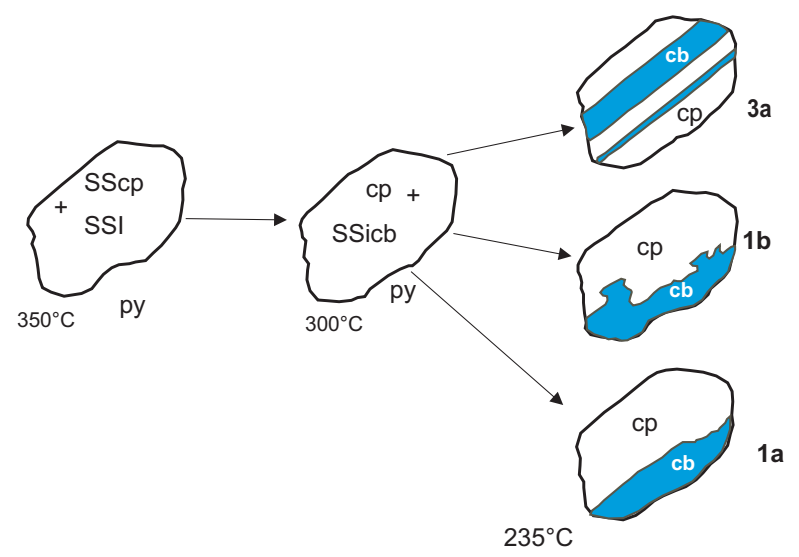

\section{Intercrescimentos entre calcopirita-pirrotita}

Neste caso a solução de origem deve ter sido mais rica em Fe e pobre em $\mathrm{Cu}$ quando comparada com os intercrescimentos descritos anteriormente. A origem pode ser explicada por uma das três formas:

a) A partir do intercrescimento py/po: 1e, por substituição seletiva de pirrotita pela calcopirita; com o qual o intercrescimento po/cp: 1e, seria intermediário a py/cp:1e com pirrotita totalmente substituída por calcopirita. Graficamente poderia ser representado assim:

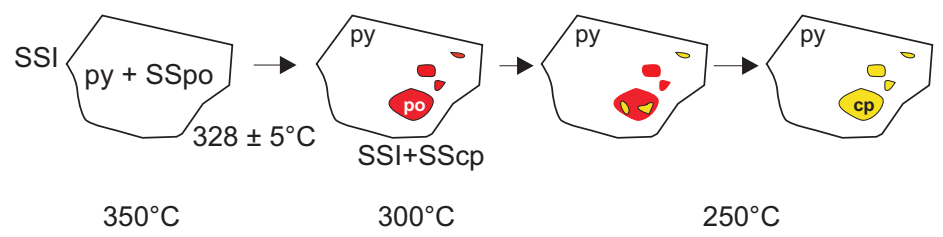

b) A partir da assembléia SScp + SSI, quando a temperatura desce abaixo de $300{ }^{\circ} \mathrm{C}$ formase calcopirita + SSicb (Kaneda et al., 1978). Sob temperaturas inferiores aos $255{ }^{\circ} \mathrm{C}$, gera-se pirrotita, formando os intercrescimentos: cp/po: 1e, 3a,1b e 1a. Segundo Kaneda et al. (1978) a $300{ }^{\circ} \mathrm{C}$ esta pirrotita teria simetria hexagonal.

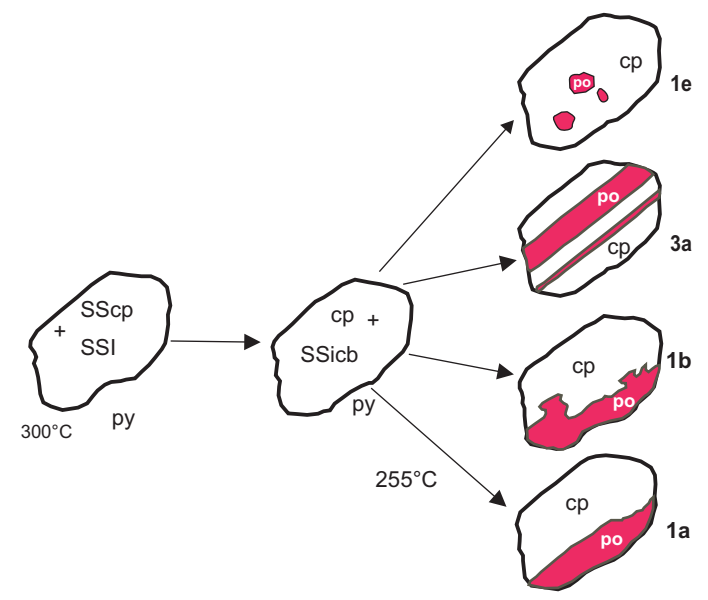


c) Com calcopirita sempre presente, a qual se origina a partir da SScp, associada à SSpo, por embaixo dos $300{ }^{\circ} \mathrm{C}$ se separa pirrotita da SSpo; gerando-se quaisquer dos intercrescimentos cp/po:3a, cp/po:1e, cp/po:1b e cp/po:1a. Ao baixar a temperatura, o equilíbrio é alterado e a pirrotita hexagonal se transforma em monoclínica quando se alcança a isoterma de $250{ }^{\circ} \mathrm{C}$ Kissin \& Scott (1982) ou de ca. $180{ }^{\circ} \mathrm{C}$ (Lusk et al., 1993). Uma possível representação é apresentada a seguir:

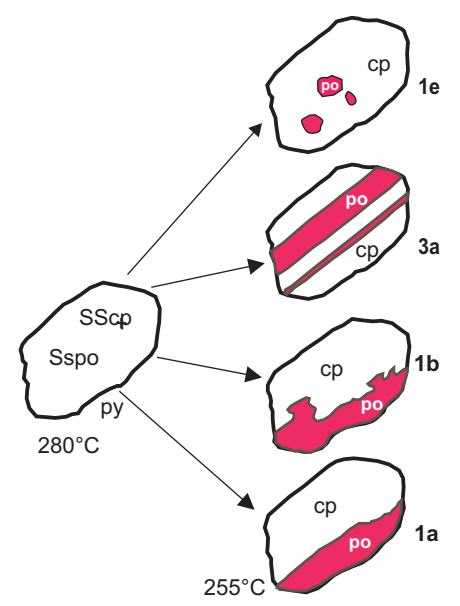

\section{Intercrescimento entre calcopirita-mackinawita}

Partindo da solução sólida original de calcopirita (SScp), que aparece abaixo de $500{ }^{\circ} \mathrm{C}$, a assembléia original poderia ter sido SScp em equilíbrio com SSpo. Os intercrescimentos 1e, 1b, 4f e 3b se explicam através da formação prévia de calcopirita, a qual coexistiria em equilíbrio metaestável com SSpo a $255^{\circ} \mathrm{C}$; a partir desta última, sob temperaturas inferiores a $255{ }^{\circ} \mathrm{C}$ separar-se-ia a mackinawita, conformando qualquer dos intercrescimentos observados. Para Clark (1966) o limite de estabilidade superior para a mackinawita seria de $135 \pm 5{ }^{\circ} \mathrm{C}$. Graficamente, estas transformações poderiam ser representadas assim:

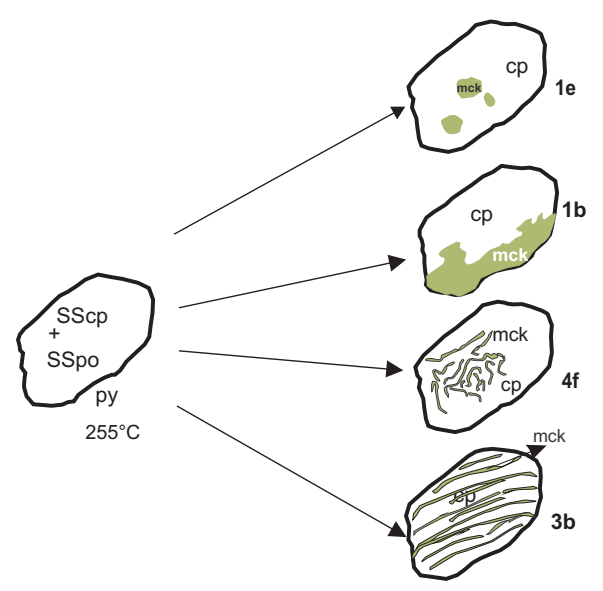

Segundo, Canchaya (com. pessoal) o intercrescimento cp/mck:1c (gráfico) indicaria a formação simultânea de calcopirita e mackinawita (semelhante a uma cristalização eutética), mas em estado sólido. 


\section{Geração das assembléias complexas}

Segundo Barton (1973) e Cabri (1973), a calcopirita estaria dissolvida na solução sólida inicial SSI até temperaturas acima de $557^{\circ} \mathrm{C}$, mas para Yund \& Kullerud (1966), este limite ocorreria a $547^{\circ} \mathrm{C} \pm 5$. Nestas condições, a assembléia ilustrada na Figura 8.8 deveria ser SSI+py+SSpo, mas SSI+SSpo e/ou SSI+py também poderiam coexistir. Assim, em temperaturas inferiores a $557{ }^{\circ} \mathrm{C}$, a calcopirita formaria a SScp (Sugaki et al., 1975), ainda no campo SSI+py, e permaneceria isolada dos outros sulfetos ao se diminuir a temperatura. Neste ponto, as fases coexistentes a $400{ }^{\circ} \mathrm{C}$ poderiam ter sido: $\mathrm{SSI}+\mathrm{py}+\mathrm{SScp}$ y/o SSpo+SSI.

Segundo Yund \& Kullerud (1966), a $300{ }^{\circ} \mathrm{C}$ separa-se pirrotita mais pura da solução sólida de pirrotita e aparece uma "tie line" de enlace entre SScp e po. Ao descer ainda mais a temperatura, aparece a SSicb como fase metaestável a partir da qual gera-se cubanita com forma de lamelas, fusiformes o ameboidais. Quando a cubanita separa-se da SSicb, torna-se mais rica em Fe (Kaneda et al., 1978) quase com a composição similar à SSpo, propiciando a formação da mackinawita. Esta evolução textural-mineralógica poderia ser diagramada como segue:

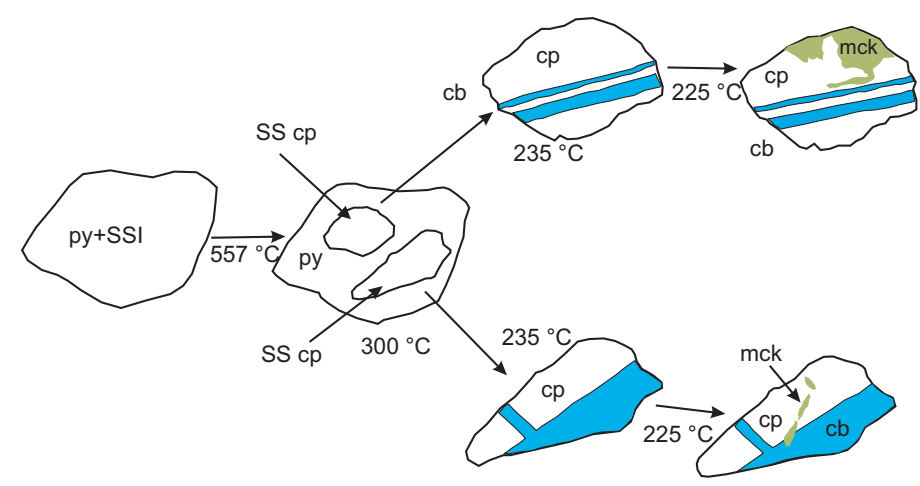




\subsection{Conclusões e recomendações}

O estudo petrográfico efetuado de 77 amostras de 22 furos de sondagem distribuídas em três perfis da jazida permitiu caracterizar os seguintes tipos de rochas: andesitos, riolitos, quartzo latitos, andesito-II, latitos, micro-granodioritos porfiríticos, micro-tonalitos porfiríticos, Pórfiros I (micro quartzo monzonitos - micro monzogranitos (?)), Pórfiro II (micro tonalitos micro leucoquartzo dioritos (?)) e micro-brechas.

A mineralogia de alteração hidrotermal permitiu a identificação de oito tipos principais de alteração: potássica, potássica-propílica, propílica-potássica, potássica-propílica/fílica, propílica, propílica-fílica, fílica-propílica e fílica. A maioria dos tipos reconhecidos representa, em realidade, combinações entre os padrões clássicos definidos na literatura.

Entre as rochas identificadas, os andesitos são os mais abundantes. Apresentam alterações potássicas, propílicas e silicificação, com freqüência combinadas entre si (alterações potássicapropílica, propílica-potássica e propílica combinada com silicificação). Riolitos aparecem apenas na parte $\mathrm{W}$ da jazida do perfil 3 e correspondem as rochas mais intensamente alteradas, tipicamente apresentam apenas a alteração fílica. Quartzo latitos, aparecem em todos os perfís e são caracterizadas por alteração propílica fraca, as vezes do tipo carbonatização e sericitização. Latitos e andesitos-II encontrados nos perfis 1 e 3, apresentam alterações fracas a moderadas de tipo propílica-potássica e potássica-propílica, respectivamente.

Micro-granodioritos, encontrados nos perfís 2 e 3, apresentam alteração propílica-potássica fraca a incipiente. No perfil 2 (centro da jazida) esta rocha passa para micro-tonalitos afetados variavelmente pelas alteraçõs fílica-propílica, propílica-fílica e fílica. Variedade de microtonalitos porfiríticos que aparecem no perfil 3, estão fraca a incipientemente alterados de forma propílica-potássica.

Os pórfiros I (micro monzonitosmicro monzogranitos, pefil 3) apresentam dois tipos de alterações principais: propílica-potássica e potássica-propílica/silicificação, ambas de fracas a incipientes, enquanto os pórfiros II (micro tonalitos - micro leuco quartzo dioritos, dominantes) apresentam alterações mais variadas, desde potássica-propílica incipiente a fraca, potássicapropílica/fílica incipiente, silicificação-propílica moderada, propílica-fílica moderada a fraca e fílica-propílica fraca a moderada. Por último, micro brecha aflora no perfil 2 e apresenta alteração propílica moderada a fraca.

Os estudos ao microscópio sob luz refletida e de química mineral confirmaram a presença de inclusões de calcopirita em cristais de pirita na jazida de $\mathrm{Cu}$ de tipo pórfiro de Cuajone. Estas inclusões se associam com pirrotita, cubanita e mackinawita, com as quais formam intercrescimentos típicos. Estes estudos mostraram que é possível estabelecer correlações entre a mineralogia que aparece em inclusões/intercrescimentos com os padrões de alteração hidrotermal, particularmente quando se consideram suas freqüências e/ou abundâncias relativas, observando-se especialmente que: 
- pirrotita está presente em todos os tipos de alteração hidrotermal estudados porém é sempre mais freqüente nos casos em que a alteração potássica está presente;

- cubanita, ainda que seja pouco abundante, é freqüente nas zonas onde há contribuição da alteração fílica. Apesar de ser encontrada também nas zonas potássica-propílica e propílica-potássica, a sua freqüência é praticamente insignificante quando comparada com a das demais fases encontradas;

- mackinawita, está mais claramente relacionada com zona de alteração propílica. Merece ser observado que este mineral também ocorre na zona fílica, mas suspeita-se, tendo em vista a distribuição das alterações, que a sua presença neste caso represente resquícios de um evento pretérito de alteração propílica. Estudos mais detalhados são necessários para resolver esta questão.

Os minerais estudados (pirita, calcopirita, pirrotita, cubanita e mackinawita) ocorrem em intercrescimentos e, no caso, da cubanita em geral associados a processos de exsolução sólida. Os resultados obtidos permitiram definir padrões de zonamento na distribuição destes minerais relacionados aos tipos de alterações hidrotermais predominantes. As análises dos dados à luz das informações extraídas de diagramas de fase permitem concluir que as temperaturas de formação de pirrotita, cubanita e mackinawita foram predominantemente inferiores a 500, 200 e $180{ }^{\circ} \mathrm{C}$, respectivamente. Assim, a origem da mineralização de $\mathrm{Cu}$ (calcopirita e cubanita) está relacionada a temperaturas entre 500 e $200{ }^{\circ} \mathrm{C}$.

Nos perfis elaborados ainda não é observado o controle mineralógico esperado relacionado à profundidade da jazida, devido à irregularidade na distribuição das alterações. Estudos adicionais são necessários para verificar a distribuição da pirrotita, cubanita e mackinawita em zonas profundas, intermediarias e periféricas respectivamente.

Os quatro tipos de intercrescimentos entre fases sulfetadas mais freqüentes encontrados na Jazida de Cuajone são: py/po:1e, cp/mck:4f, cp/po:1b e cp/mck/1b, no entanto que os intercrescimentos comuns quando comparados com as jazidas de Cerro Verde, Toromcho e Quellaveco são: cp/cmk:1e, cp/cb:1a e cp/cb:3a. Os intercrescimentos mais freqüentes na zona de alteração potássica são cp/po:1b e py/po:1e, enquanto que, na zona potássica-propílica são py/po:1e e cp/mck:4f, na alteração propílica-potássica py/po:1e e cp/mck:4f, na zona propílica cp/mck:4f e py/po:1e, na zona potássica-propílica, fílica cp/po:1b e cp/mck:4f, na zona propílica-fílica cp/po:1b e cp/mck:4f, na zona propílica-fílica $\mathrm{cp} /$ po:1b e cp/mck:4f e, finalmente, na alteração fílica cp/po:1b e cp/mck:4f.

O quimismo das fases sulfetadas é muito similar a composição ideal esperada. Entre os elementos traços idenficados significativamente nas análises de algumas amostras, merecem ser destacados $\mathrm{Cu}$, Au e Ni em pirita; Zn e Au em calcopirita; Zn e Ag e Au na cubanita; Cu, Zn e $\mathrm{Au}$ em pirrotita e em mackinawita $\mathrm{Cu}$, Ni e $\mathrm{Zn}$, Au e Ag. 
A ocorrência de calcopirita, pirrotita e, particularmente cubanita e mackinawita como inclusões e/ou intercrescimentos muito diminutos faz com que passem despercebidas na maioria dos estudos rotineiros ao microscópio sob luz refletida. Recomenda-se examinar as amostras de jazidas de tipo $\mathrm{Cu}$ porfirítico e similares em detalhe e sob amplificações elevadas para verificar a presença destas fases, cujas associações e distribuições podem se converter em informações muito úteis para a prospeç̧ão.

Trabalhos futuros recomendados para a melhor caracterização e compreensão da mineralogia e evolução da jazida de Cuajone, incluem (a) análises químicas em rocha total e pontuais nas fases minerais primárias e de alteração hidrotermal e (b) análises de catodoluminescência e/ou difratometria de raios X para constrastar fases primárias e secundárias de difícil separação ao microscópio comum (e.g., quartzo, feldspatos alcalinos). 



\section{Referências Bibliográficas}

Aguilar, O.; Kinien, A. \& Castilla, B. (1974). Los pórfidos de cobre peruanos del Perú. Em: Congreso Peruano Geológico, p. 58. Lima - Perú.

AmCOFF, Ö. L. (1981). Heating experiments of chalcopirite - pirrotite ores: studies on the stability of the intermediate solid solution. N.Jb.Miner. Mh, H12, pp. 553-568.

Amstutz, G. C. (1971). Glossary of Geology. Stuttgart.

Anthony, J. W.; Bideaux, R. A.; Bladh, K. W. \& Nichols, M. C. (1990). Handbook of Mineralogy. Mineral Data Publishing. Tucson-Arizona.

Augustithis, S. S. (1995). Atlas of the textural patterns of ore minerals and metallogenic processes. Berlin, New York.

Barúa, V. (1961). Reconocimiento geológico zona de Tacna y Moquegua. Em: Cong.Nac. Geología Soc. Geol.Perú, volume 2, pp. 35-59.

Bartholomé, P. (1958). On the paragenesis of copper ores. Studia Universitatis Lovanium, Leopoldville, 4, pp. 1-31.

Barton, B. P. JR. (1973). Solid solution in the system Cu-Fe-S. Part I: The Cu-S and Cu-Fe-S joins. Economic Geology, 68, pp. 455-465.

Bastin, E. S.; Graton, L. C.; Lindgren, W.; Newhouse, W. H.; Schwartz, G. M. \& N., Short M. (1931). Criteria of age relations of minerals with especial reference to polished sections of ores. Economic Geology, 36, pp. 562-610.

BAStin, G. F. (1984). An iterative procedure for the correction of secondary fluorescence effects in electron-probe microanalysis near phase boundaries. Spectrochimica Acta, 39B(12), pp. $1517-1522$.

Beane, R.E. \& Titley, S.R. (1981). Porphyry Copper Deposits Part II. Hydrothermal Alteration and Mineralization. Economic Geology, in 75th Anniversary, pp. 235-269.

Beckinsale, R. D.; Sánchez-Fernandez, A. W.; Brook, M.; Cobbing, E. J.; Taylor, W. P. \& Moore, N. D. (1985). Magmatism at a plate edge: The Peruvian Andes. capitulo Rb-Sr whole-rock isochron and K-Ar age determinations for the Coastal batholith of Perú, pp. 177-202. Glasgow, New York, Halsted. 
Bellido, E. (1979). Geologia del Cuadrángulo de Moquegua. Numero 15 em serie A, p. 78. Carta geológica nacional - INGEMMET.

Bellido, E. \& Guevara, C. (1963). Geología de los cuadrángulos de Punta de Bombom y Clemesí. 2 (5), p. 92. Comisión de la carta geológica nacional del Perú.

Bellido, E. \& Landa, C. (1965). Mapa Geológico del cuadrángulo de Moquegua (1:100000). Comision de la carta geológica nacional, Lima - Perú.

Bellón, M. \& Lefevre, C. (1976). Données geochonométriques sur le volcanisme andin dans le sud du Pérou. Acad. Sci. Paris Comptes Rendus, 283, pp. 1-4.

Blanchart, R. (1968). Interpretation of leached outcrops. 66, p. 196. Nevada Bureau of Mines.

Borchert, H. (1934). Uber entmischungen im system Cu-Fe-S und Bedeutung as geologisches thermometer. Chemie d. Erde, 9, pp. 145-172.

Cabri, J. L. (1973). New data on phase relations in the Cu-Fe-S system. Economic Geology, 68, pp. 443-454.

Cabri, L. J.; Blank, H.; El Goresy, A.; Laflamme, J. H.; Nobiling, R.; Sizgoric, M. B. \& Traxel, K. (1984). Quantitative trace-element analyses of sulfides from Sudbury and stillwater by proton microprobe. The Canadian Mineralogist, 22, pp. 521-542.

Cameron, E.N. (1961). Ore microscopy. New York, London.

Canchaya, M.S. (1993). El ensamble pirita-calcopirita-pirrotita-cubanita-mackinawita en los pórfidos de cobre peruanos. Em: VI Congreso Peruano de Geología, Soc. Geol. Perú, p. 108.

Canchaya, S. \& Cardoso, M. (1984). Tabla de intercrecimientos geométricos de minerales opacos. Com. pess.

Carten, R. B. (1986). Sodium-calcium metasomatism: chemical, temporal, and spatial relationships at the Yerington, Nevada, porphyry copper deposit. Economic Geology, 81, pp. $1495-1519$.

Castro, D. A. (1989). Petrografía básica. Madrid.

Caye, R.; Cervelle, B.; Cesbron, F.; Oudin, E.; Picot, P. \& F., Pillard (1988). Isocubanite, a new definition of the cubic polymorph of cubanite $\mathrm{CuFe}_{2} \mathrm{~S}_{3}$. Mineralogycal Magazine, 52, pp. 509-514.

Chacón, A. N. (1995). Geomorfología. Em: Geología del Perú, Numero 55 em A, pp. 7-14. Carta Geológica Nacional, Lima-Perú.

Clark, A. H. (1966). Some comments on the composition and stability relations of mackinawite. Neues Jahrb Mineralogie Monatsh, 10, pp. 300-304. 
Clark, A. H.; Farrar, E.; Kontak, D.J.; Langridge, R.J.; Arenas, M.J.; France, L.J.; Mcbride, S.L.; Woodman, P.L.; Wasteneys, H.A.; Sandeman, H.A. \& Archibald., D.A. (1990a). Geologic and geochronologic constraints on the metallogenetic evolution of the Andes of southeastern Perú. Economic Geology, 85, pp. 1520-1583.

Clark, H. A; Tosdal, M. R.; Farrar, E. \& Plazoles, A. (1990b). Geomorphologic Environment and Age of Supergene Enrichment of the Cuajone, Quellaveco and Toquepala Porphyry Copper Deposit, Southeastern Perú. Economic Geology, 85, pp. 1604-1628.

Cobbing, E. J. (1998). The coastal batholith and other aspects of andean magmatism in Perú. pp. 5-20. Soc. Geol. Perú.

Cobbing, J. \& Pitcher, W. (1972b). Plate tectónics and the Peruvian Andes. Nature; Physical Science, 240 (99), pp. 51-53.

Concha, O. \& Bernabé, H. (1999). Geología y Génesis de Cuajone. Relatório Técnico, SouthePerú Corporation.

Craig, J. \& Vaughan, D. (1994). Ore microscopy and ore petrography. New York, 2th edição.

Craig, J. R. \& Scott, S. D. (1974). Sulfide phase equilibria. Em: Mineralogical Society of America (Ed.), Sulfide - Mineralogy; short course notes, volume 1, capitulo Sulfide phase equilibria, pp. CS1-CS110. Lithocrafters Michigan.

DeMichele, V. (1972). Atlas de minéralogie et pétrographie. Paris: Grange Bateliére.

Demidov, V. \& MuÑoz, J. (1993). Introducción a la Mineragrafía. Cuba.

Dilles, J. H. \& EinAudi, M. T. (1992). Wall-rock alteration and hydrothermal flow paths about the Ann-Mason porphyry copper deposit, Nevada-A 6- km vertical reconstruction. Economic Geology, 87, pp. 1963-2001.

Edwards, A. B. (1954). Textures of the ore minerals and their significance. Melbourne.

Estrada, F. (1985). Geología de Quellaveco. volume 46, pp. 65-86. Bol. Soc. Geol. Perú.

Evans, H. (1964). Valleriite and the new iron sulfide, mackinawite. U.S. Geol. Survey prof., 475-D, pp. D64-D69.

Fleet, E. M. (2006). Phase equilibria at high temperatures. Em: Reviews in Mineralogy 8 Geochemistry, volume 61, pp. 365-419. Mineralogical Society of America.

GaÁL, G. \& Isohanni, M. (1979). Characteristics of igneous intrusions and various wall rocks in some Precambrian porphyry copper-molybdenum deposits in Pohjanmaa, Finland. Economic Geology, 74, pp. 1198-1210.

Gehlen, K. \& Kullerud, G. (1962). Pirrhotite-pyrite-chalcopirite relations. Carnegie Inst. Washington Year Book, 61, pp. 154-155. 
Giggenbach, W. F. (1997). Geo-chemistry of hydrothermal ore deposits. capitulo The origin and evolution of fluids in magmatic hydrothermal systems, pp. 737-796. New York.

Goldstein, J. I.; Newbury, D.E.; Echlin, P.; Joy, D.C.; Romig, A. D.; Lyman, C. E.; Fioni, C. \& Lifshin, E. (1992). Scanning Electron Microscopy and X-ray Microanalysis. New York.

Gomez, M. \& Fabas, P. (2006). Mineralogical controls on mine drainage of the abandoned Ervedosa tin mine in north-eastern Portugal. Applied Geochemistry, 21, pp. 1322-1334.

Gustafson, L. B. (1978). Some major factors of porphyry copper genesis. Economic Geology, 73, pp. 600-607.

Gustafson, L. B. \& Hunt, J. P. (1975). The porphyry copper deposits at El Salvador, Chile. Economic Geology, 70, pp. 857-912.

Gustafson, L. B. \& Titley, S. R. (1978). Porphyry copper deposits of the southwestern Pacific islands and Australia: Preface. Economic Geology, 73, pp. 97-599.

Hagel, E. (1994). Microscopia de menas. Concepción - Chile.

Hemley, J. J.; Marinenko, J. W.; Montoya, J. W. \& Luce, R. W. (1980). Equilibria in the system $\mathrm{Al}_{2} \mathrm{O}_{3} \mathrm{SiO}_{2} \mathrm{H}_{2} \mathrm{O}$ and some implications for alteration/mineralization process. Economic Geology, 75, pp. 210-228.

ingemmet, Instituto Geológico Minero Metalúrgico (2000). Estudio de los recursos minerales del Perú, Franja No 1. Em: Geología Económica, B, p. 196. INGEMMET.

Inoue, A. (1995). Origin and Mineralogy of Clays. capitulo Formation of clay minerals in hydrothermal environments, pp. 268-330. Springer-Verlag, Berlin, Heidelberg.

IXeR, R. A. (1990). Atlas of opaque and ore minerals in their associations. New York.

Jenks, W. F. (1946). Preliminary note on geologic studies on the Pacific Slope in Southern Perú. American Journal Sciencie, 244 (5), pp. 367-372.

Kaneda, H.; Shou, T.; Takenouchi, S. \& Imai, H. (1978). Geological studies of the mineral deposits in Japan and east Asia. capitulo Cu-Fe-S Mineral Syntheses, p. 392. Japan.

KerR, P. F. (1972). Mineralogia óptica. Madrid.

Kirkham, R. V. (1972). Porphyry deposits (in Report of Activities, Part B; November 1971 to March 1972). Geological Survey of Canada, 72 (1), pp. 64-64.

Kissin, S. A. \& Scott, S. D. (1982). Phase relation involving pyrrhotite below $350{ }^{\circ} \mathrm{C}$. Economic Geology, 77, pp. 1739-1754. 
Klein, C. (2002). Manual de mineralogía : basado en la obra de J. Dana. Cornelis Klein, Cornelius S. Hurlbut, Jr. Barcelona, 4th edição.

Kojima, S. \& Sugaki, A. (1984). Phase relations in the central portion of the Cu-Fe-Zn-S system between $800{ }^{\circ} \mathrm{C}$ and $500{ }^{\circ} \mathrm{C}$. Mineral. Journal, 12, pp. 15-28.

Kojima, S. \& Sugaki, A. (1985). Phase relations in the Cu-Fe-Zn-S system between $500{ }^{\circ}$ and $300{ }^{\circ} \mathrm{C}$ under hydrothermal conditions. Economic Geology, 80, pp. 158-171.

Kouvo, O. \& Vuorelainen, Y. (1963). A tetragonal iron sulfide. The Americam Mineralogist, 48, pp. 511-524.

KRuPP, R. E. (1994). Phase relations and phase transformations between the low-temperature iron sulfides mackinawite, greigite and smythite. Eur.J. Mineral, 6, pp. 265-278.

LaCy, W. C. (1958). Porphyry copper deposit, Cuajone, Perú. Am. Inst. Mining Metall. and Petroleum Engineers Trans., 11, pp. 104-107.

Lemaitre, R. W. (1989). A classification of igneous rocks and glossary of terms. (Reccommendations of the International Union of Geological Sciences Subcommission on the Systematics of Igneous Rocks ). Blackwell, Oxford.

Lennie, A. R.; R., England K. E. \& Vaughan, D. J. (1995a). Transformation of synthetic mackinawite to hexagonal pyrrhotite: A kinetic study. Americam Mineralogist, 80, pp. 960-967.

Lennie, A. R. \& Vaughan, D. J. (1996). Spectroscopic studies of iron formation and phase relations at low temperatures. Em: Mineral Spectroscopy, volume 5, pp. 117-131. Geochemical Society Special Publication,.

Lowell, J. D. \& Guilbert, J. M. (1970). Lateral and vertical alteration mineralization zoning in porphyry copper ore deposits. Economic Geology, 65, pp. 373-408.

Lusk, J. \& BrAy, M. (2002). Phase relations and the electrochemical determination of sulfur fugacity for selected reactions in the $\mathrm{Cu}-\mathrm{Fe}-\mathrm{S}$ and Fe-S systems at 1 bar and temperatures between $185{ }^{\circ} \mathrm{C}$ and $460{ }^{\circ} \mathrm{C}$. Chemical Geology, 192, pp. 227-248.

Lusk, J. \& CAlder, B. (2004). The composition of sphalerite and associated sulfides in reactions of the $\mathrm{Cu}-\mathrm{Fe}-\mathrm{Zn}-\mathrm{S}, \mathrm{Fe}-\mathrm{Zn}-\mathrm{S}$ and $\mathrm{Cu}-\mathrm{Fe}-\mathrm{S}$ systems at 1 bar and temperatures between $250{ }^{\circ} \mathrm{C}$ and $535{ }^{\circ} \mathrm{C}$. Chemical Geology, 203, pp. 319-345.

Lusk, J.; Scott, S. D. \& Ford, C. E. (1993). Phase relations in the Fe-Zn-S system to 5 Kbars and temperatures between $325{ }^{\circ} \mathrm{C}$ and $150{ }^{\circ} \mathrm{C}$. Economic Geology, 88, pp. 1880-1903.

MacKenzie, W. S. (1994). A color of rocks and minerals in thin section. New York. 
MacKenzie, W. S. \& Guilford, C. (1980). Atlas of rock-forming minerals in thin section. London, New York.

MacKenzie, W.S.; Donaldson, C.H. \& Guilford, C. (1982). Atlas of igneous rocks and their textures. Harlow.

MacKinstry, H. (1959). Mineral assemblages in sulfide ores; The system Cu-Fe-S-O. Economic Geology, 54, pp. 975-1001.

Maclean, W. H.; Cabri, L. J. \& Gill, J. E. (1972). Exolution products in heated chalcopirite. Canadian Journal Earth Sciencie, 9, pp. 1305-1317.

MaKenzie, W. S. \& Adams, A. E. (1997). Atlas en color de rocas y minerales en lámina delgada. España, 1th edição.

Maksaev, V. (2001). Pórfidos Cupríferos. Curso.

Manrique, J. \& Plazolles, A. (1975). Geología de Cuajone. 46, pp. 137-150. Bol. Soc. Geol. Perú.

Marocco, R. \& Noblet, C. (1990). Sedimentation, tectonism and volcanism relationships in two Andean basins of southern Perú. Geologische Rundschau, 79, pp. 111-120.

McBride, S. L. (1977). A K-Ar Study of the Cordillera Real, Bolivia, and its regional setting. Tese de Doutoramento, Queens University, Kingston Ontario Canada.

Meldrum, J. L. (1998). Determination of the sulphide oxidation potential of mine tailings from Rankin Inlet, Nunavut, at sub-zero temperatures. Dissertação de Mestrado, Queens University, Kingston Ontario Canada.

Melgarejo, J. (2003). Atlas de asociaciones minerales en lámina delgada. España.

Mendivil, S. (1965). Geología de los cuadrángulos de Maure y Antajave. 10, p. 99. Comisión de la carta geológica nacional, Perú.

Merwin, H. E. \& Lombard, R. H. (1937). The system Cu-Fe-S. Economic Geology, 32, pp. 203-284.

Meyer, C. \& Hemley, J. J. (1967). Geochemistry of hydrotermal ore deposits. capitulo Wall rock alteration, pp. 166-232. New York.

Mukaiyama, H. \& Izawa, E. (1970). Volcanism and ore genesis. capitulo Phase relations in the $\mathrm{Cu}-\mathrm{Fe}-\mathrm{S}$ system: the copper deficient part., pp. 339-355. University Tokio.

Muñoz, C. A. (1980). Yacimientos porfiríticos de cobre en el Perú. Tese de Doutoramento, Universidad de San Marcos. Lima - Perú. 
Naldrett, A. \& Kullerud, G. (1966). Sulfurization in nature; two examples. Geological Society of America, Special paper, pp. 115-116.

Nassau, K. (1978). Geología Minera del Departamento de Tacna. 46, pp. 187-204. Soc. Geol. Perú.

Nesse, W.D. (1991). Introduction to optical mineralogy. Oxford Univ. Press, New York, USA, 2nd Edition.

Oelsner, O. (1966). Atlas of the most important ore mineral parageneses unde the microscope. Oxford, New York.

Palacios, O. (1995). Geología Histórica y Evolución Tectónica. Em: Geología del Perú, pp. 15-44. Carta Geológica Nacional.

Pankratz, L. B. \& King, E. G. (1970). High temperature enthalpies and entropies of chalcopirite and bornite. U. S. Bur. Mines Rept. Invest., 7435.

Park, F. Ch. \& MacDiarmid, A. R. (1981). Yacimientos minerales. Barcelona.

PARK, G. (1998). Petrographic and Litogeochemical Alteration Study of the Cuajone and Toquepala Porphyry Copper Deposits, Perú. Relatório Técnico, Souther Perú Copper Corporation.

Parsons, A. B. (1933). The porphyry coppers. American Institute of Mining and Metallurgical Engineers, New York.

Pichler, H. \& Schmitt-Riegraf (1997). Rock-forming Minerals in Thin Section. Chapman and Hall, London.

Pierce, F. W. \& Bolm, J. G. (1995). Porphyry copper deposits of the American Cordillera. Arizona.

Pirajno, F. (1992). Hydrothermal mineral deposits : principles and fundamental concepts for the exploration geologist. Heidelberg.

Pitcher, W. S. (1974). The Mesozoic and Cenozoic batholiths of Perú. Pacif. Geology, 8, pp. 51-62.

Pitcher, W. S.; Atherton, M. P; Cobbing, E. J. \& Bekinsale, R. D. (1985). Magmatism at a plate edge The Peruvian Andes. Glasgow, New York, Halsted.

Pitcher, W. S. \& Cobbing, E. J. (1985). Magmatism at a plate edge: The Peruvian Andes. capitulo Phanerozoic plutonism in the Peruvian Andes, pp. 19-25. New York.

Ramdohr, P. (1969). The ore minerals and their intergrowths. Akademie- Verlag.

Ramdohr, P. (1980). Ore minerals and their intergrowths. Oxford, New York, Toronto. 
Rose, A. W. (1970). Zonal relation of wallrock alteration and sulfide distribution at porphyry copper deposits. Economic Geology, 65, pp. 920-936.

Sanchez, A. \& León, W. (1995). Rocas Igneas. Em: Geología del Perú, Numero 55 em A, pp. 7-14. Bol. Carta Geológica Nacional, Lima-Perú.

Satchwell, P. C. (1983). Geologia de la Mina Cuajone. volume 72, pp. 127-146. Bol. Sociedad Geológica del Perú.

Sébrier, M.; Fornari, M.; Vatin-Perignon, N.; Vivier, G. \& Cabrera, J. (1983). Nuevas edades radiométricas del volcanismo Cenozoico del Sur del Perú: implicancias en la tectonogénesis andina Nuevas edades radiométricas del volcanismo Cenozoico del Sur del Perú: implicancias en la tectonogénesis andina. Em: V congreso Peruano de Geología, pp. GR-16. Lima - Perú.

Schouten, C. (1962). Determination tables for ore microscopy. Amsterdam, New York.

Sillitoe, R. H. (1985). Ore-related breccias in volcano-plutonic arcs. Economic Geology, 80, pp. 1467-1514.

Simon, G.; Kesler, S. \& Essene, E. (2000). Gold in Porphyry Copper Deposits: Experimental determination of the distribution of gold in the $\mathrm{Cu}$-Fe-S system at $400{ }^{\circ} \mathrm{C}$ to $700{ }^{\circ} \mathrm{C}$. Economic Geology, 95, pp. 259-270.

Singer, D.A. (2005). Porphyry copper dhenryHenryheposits of the world: Database, map, and gradeand tonnage models. U.S. Geological Survey Open-file Report.

http://pubs.usgs.gov/of/2005/1060/

Smirnov, V. I. (1982). Geología de yacimientos minerales. Mir, Moscú.

Smith, R. E. (1966). The geology of Mandurama Panuara. Journal and Proceedings of the Royal Society New South Wales, 10, pp. 239-262.

Steinmann, G. (1929). Geología del Perú. Heidelberg Carl Winters.

Stevenson, F.B. \& Damiani, O. (1968). Interpretación estructural del depósito de Toquepala. Relatório Técnico, Southern Perú Copper Corporation, Lima - Perú.

Stewart, J. \& Snelling, N. (1971). K-Ar determinations on minerals from the Peruvian coastal batholith. Relatório Técnico 2, Isotope Geology Unit, Inst. Geol. Sci..

Sugaki, A.; Shima, H.; Kitakaze, A. \& Harada, H. (1975). Isothermal phase relations in the system $\mathrm{Cu}$-Fe-S under hidrothermal conditions at $350{ }^{\circ} \mathrm{C}$ and $300{ }^{\circ} \mathrm{C}$. Economic Geology, 70, pp. 806-823.

Titley, S. R. (1975). Geological characteristics and environment of some porphyry copper occurrences in the Southwestern Pacific. Economic Geology, 70, pp. 499-514. 
Titley, S. R. \& Beane, R. E. (1981). Porphyry copper deposits, Part I: Geological settings, petrology and tectogenesis. Economic Geology, 75th anniv., pp. 214-235.

Titley, S. R. \& Hicks, C. L. (1966). Geology of the porphyry copper deposits, southwestern North America. Tucson.

Torpoco, C. (1979). Petrografía, alteraciones y mineralización del yacimiento de Quellaveco - Moquegua. pp. 117-134. Soc. Geol. Perú.

Tosdal, R. M.; Clark, A. H. \& Farrar, E. (1984). Cenozoic polyphase landscape and tectonic evolution of the Cordillera Occidental southermost Perú. Geological Society of America Bulletin, 95, pp. $1318-1332$.

Tosdal, R. M.; Farrar, E. \& Clark, A.H. (1981). K-Ag geocronology of the late Cenozoic volcanic rocks of the Cordeillera Occidental, southern most Perú. Journal of volcanology and geothermal research, 10, pp. 157-173.

Townley, K. B. (2001). Hidrotermalismo y Modelos de Yacimientos. Chile. Curso.

Troger, W. E. (1979). Optical determination of rock-forming minerals - part 1 determination tables. Stuttgart.

Udubasa, G. (1982). The state of the eart. capitulo Rutile of postmagmatic mineral formation, pp. 784-793. Springer Berlin.

UyÉn, A. D. (1981). Geología y Mineralización de la mina Cuajone. Relatório Técnico, Universidad de San Agustin.

Uytenbogandit, W. (1971). Tables for microscopic identification of ore minerals. Amsterdam, New York.

Valera, L. J. (1987). Geología de los Depósitos de Minerales Metálicos. Lima - Perú.

Vaughan, D. J. \& Craig, J. R. (1978). Mineral Chemistry of metal sulfides. London, New York, Melbourne.

Williams, H.; Turner, F. J. \& Guilbert, C. M. (1982). An introduction to the Study of Rocks in Thin Sections. New York.

Wilson, J. J. \& García, W. (1962). Geología de los cuadrángulos de Pachia y Palca. 2 (4), p. 82. Comisión de la carta geológica nacional.

Yund, A. R. \& Kullerud, G. (1966). Thermal stability of assemblages in the Cu-Fe-S system. Journal of Petrology, 7, pp. 454-488.

Zoka, H.; TAylor, L. A. \& TAkeno, S. (1972). Compositional variations in natural mackinawite and the results of heating experiments. J. Sci. Hiroshima Univ., ser. C, 7, pp. $37-53$. 
Zweng, L. P. \& Clark, H. A. (1995). Hypogene Evolution of the Toquepala Porphyry Copper-Molybdenum Deposit, Moquegua, Southeastern Perú. Arizona Geological Society Digest, 20, pp. 566-612.

Zweng, P. L. (1984). Evolution of the Toquepala porphyry Cu (-Mo) deposit, Perú. Tese de Doutoramento, Queens University, Kingston. 
Anexos 
ANEXO 1

\section{LISTA DE ABREVIATURAS}

Minerais e grupo de minerais

Nome

Anidrita

Barita

Biotita

Bismutina

Bornita

Calcopirita

Calcosita

Covelita

Cubanita

Digenita

Diaspora

Epidoto

Esfalerita

Esfênio (titanita)

Enargita

Galena

Haycokita

Hematita

Horneblenda

Ilmenita

Isocubanita

Leucoxênio

Mackinawita

Magnetita

Molibdenita

Mooihoekita

Muscovita

Ortosa

Pirita

Pirrotita

Rutilo

Sericita

Troilita

Talnakita

Valerita

Yeso

Zircão

Wolframita

Anfíbólios

Argilas

Carbonatos

Cloritas

Cobres Cinzentos

Feldspatos

Feldspatos Potássicos

Gangas

Limolitas
Abreviaturas

anh

bar

bt

bmt

bor

$\mathrm{cp}$

cc

$\mathrm{cv}$

$\mathrm{cb}$

dg

$\mathrm{dp}$

ep

ef

efn

en

gl

hc

$\mathrm{hm}$

hor

il

icb

LCX

mck

$\mathrm{mg}$

$\mathrm{mb}$

$\mathrm{mh}$

mus

ort

py

po

rt

ser

tr

tal

val

ys

zir

wf

ANFs

$\mathrm{ARCs}$

$\mathrm{CBs}$

CLOs

$\mathrm{CGR}_{\mathrm{S}}$

FPs

FPKs

GGs

LMs 
Maior que

Maior o igual que

Menor que

Semelhante a

Forte ou abundante

Forte

Débil

Moderado

Insipiente

Inicial 
Micas $\quad$ MCs

Opacos OPs

Óxidos $\quad$ OXs

Piroxênios $\quad$ PXs

Plagioclásios $\quad$ PGLs

Quartzo qz

Silicatos SILs

Sulfetos $\quad$ SULs

Solução Sólida $\quad$ SS

Solução Sólida intermediária $\quad$ SSI

Solução Sólida de calcopirita $\quad$ SScp

Solução Sólida de pirrotita $\quad$ SSpo

Solução Sólida de isocubanita $\quad$ SSicb

\section{Tipo de rochas}

Andesito $\quad$ And-Pf

Andesito-II Ltand

Riolito Rio

Hidrotermalito/possível: Riolito Hid/Rio

Pórfiro alterado a hidrotermalito/ possível: Riolito Pfa-Hid/Rio

Pórfiro alterado/possível: Riolito Pfa/Rio

Pórfiro - I (micro quartzo monzonitos- micro monzogranitos) Pf-I

Pórfiro - II (micro tonalitos - micro leucoquartzo dioritos) Pf-II

Quartzo Latito Qlp

Hidrotermalito/possível: Andesito Hid/And

Micro-granodiorito porfirítico $\quad$ Mgrp

Hidrotermalito/possível: Micro-granodiorito porfirítico Hid/ Mgrp

Micro-brecha $\quad$ MBx

Latito $\quad$ Lt

Hidrotermalito Hid

Micro-tonalito porfirítico Mtnp

Pórfiro alterado/possível: Micro-granodiorito porfirítico $\quad$ Pfa/Mgrp

Pórfiro alterado/possível: Pórfiro-II $\quad$ Pfa/Pf-II

\section{Tipo de alterações}

Potássica

$\mathrm{K}$

Potássica-Propílica K-P

Propílica-Potássica $\quad$ P-K

Potássica-Propílica/ Fílica $\quad$ K-P/F

Propílica $\quad$ P

Propílica-Fílica $\quad$ P-F

Fílica-Propílica $\quad$ F-P

Fílica $\quad$ F

Silicificação Silf

Sericitização $\quad$ Ser

Carbonatização $\quad$ (CBs)

\section{Outros}

Igual que

Escasso

$(-)$

Muito escasso 


\begin{tabular}{|c|c|c|c|c|c|c|c|c|c|c|c|c|c|c|c|c|c|c|c|c|c|c|c|c|}
\hline \multirow{2}{*}{ 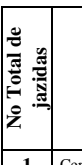 } & \multirow{2}{*}{ Nome } & \multirow{2}{*}{ Ourros nomes } & \multirow{2}{*}{ Localiasasio } & \multirow{2}{*}{\multicolumn{2}{|c|}{ 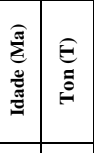 }} & \multirow{2}{*}{\multicolumn{3}{|c|}{ Teor }} & \multirow{2}{*}{\begin{tabular}{|l} 
Datate \\
decsorim \\
cento
\end{tabular}} & \multirow{2}{*}{$\begin{array}{ll}\substack{\text { Inctui } \\
\text { tumberm }} \\
\text { ton }\end{array}$} & \multirow{2}{*}{ 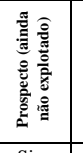 } & \multirow[b]{2}{*}{ observaşês } & \multicolumn{8}{|c|}{ Mineralogia considerada por Muйoz } & \multirow{2}{*}{ 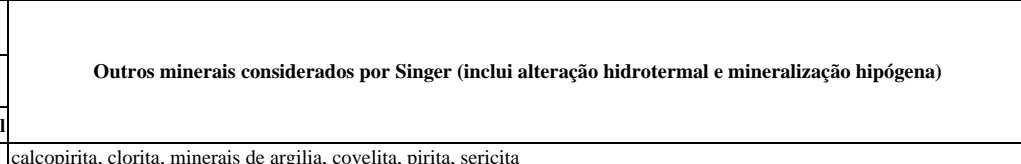 } & \multirow{2}{*}{ Rochas mineralizadas } & \multirow{2}{*}{ Rochas encaixantes } & \multirow{2}{*}{$\frac{5}{3}$} \\
\hline & & & & & & & & & & & & & $\begin{array}{c}\text { Mine } \\
\text { Propilica } \\
\end{array}$ & raglaid ath & $\begin{array}{l}\text { eraça hidrote } \\
\text { Filica } \\
\end{array}$ & Protisisica & zoman Exterma & 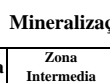 & tatipogena & zonan central & & & & \\
\hline 2 & Toquenala & Pampa Negara & Tacana & 5723 & $\int_{20}^{0} 0_{0.5}^{0}$ & 0.04 & & 0 & 18 century & & $\operatorname{sim}$ & 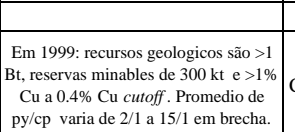 & cLosep-acad & & qasser & ante) & py-barcp & py-cp & 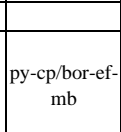 & & 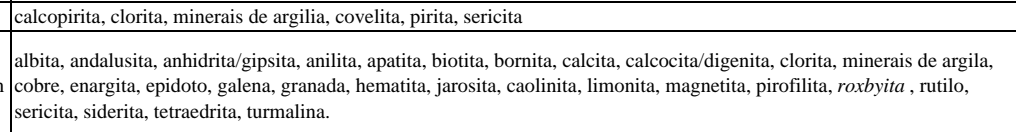 & 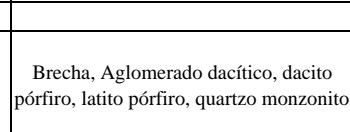 & 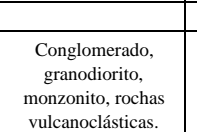 & \\
\hline 3 & Quellaveco & Quellaveco & Moquegua & 5497 & 40.055 & 0.021 & & 0 & 1955 & & & 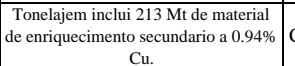 & clossep-ace & & qaserersilf & 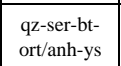 & pyyp & 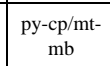 & 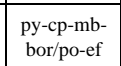 & 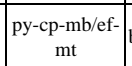 & 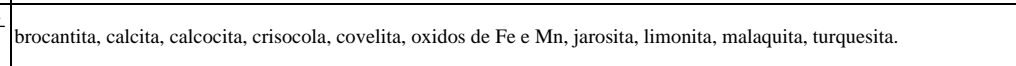 & brecha, monzonito porffiro & & \\
\hline 4 & cuajone & & Moquegua & $511^{16}$ & 500.6. & 0.0214 & & 0 & 1939 & 1976 & & & 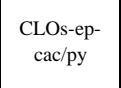 & & qa-sererARCS & be FKPs & pycp & py-cpene-ef & py-cp-mb & py-cp.mb : & 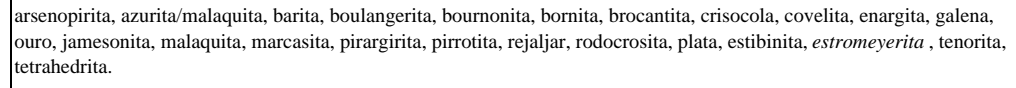 & $\begin{array}{l}\text { Brecha, atitio porfirio, quartzon } \\
\text { porfirio }\end{array}$ & 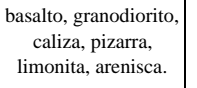 & \\
\hline 5 & chapi & & & 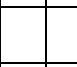 & 0 & 0 & 0 & 0 & & & sim & 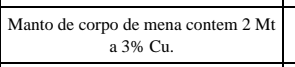 & & & & & & & & & 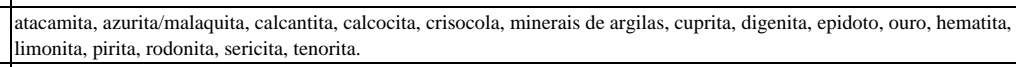 & andesito porfirio, poffirio quartifiero & & \\
\hline${ }^{6}$ & Ceron Nega & & & 577 & 0.53 & 0 & 0 & o & 1995 & & & 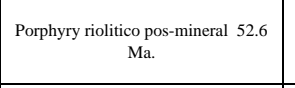 & & & & & & & & & 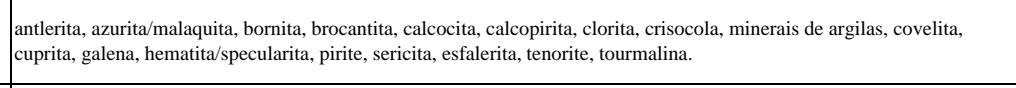 & Brecha, porfirit riolito, tuff dacticico & 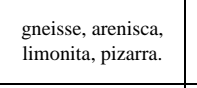 & 1.7 \\
\hline 7 & Cerroverte & Sama Rosa & Arequipa & 58 100. & ${ }_{90}^{00.6}$ & 0.01 & o & 0 & 1916 & 1994 & & & 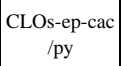 & & qassersilif & tor-blonht & pygancep & $\substack{\text { py-cplen- } \\
\text { mb }}$ & 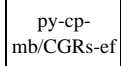 & 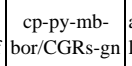 & 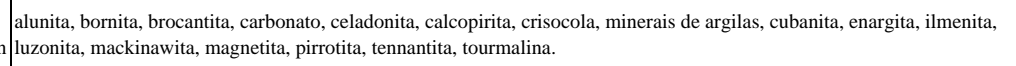 & 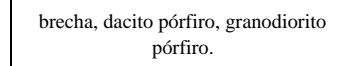 & 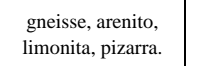 & \\
\hline 8 & 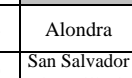 & & & & $0_{0}^{\circ}$ & 0 & 0 & 0 & & & $\frac{\operatorname{sim}}{\operatorname{sim}}$ & 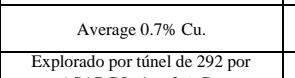 & & & & & & & & & 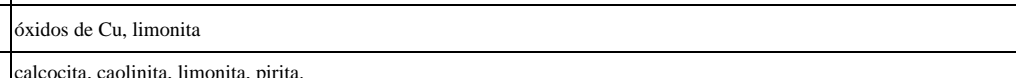 & 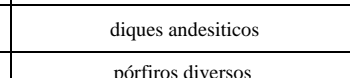 & & \\
\hline 10 & Quechua & & & & o & o & 0 & o & & & sim & & & & & & & & & & 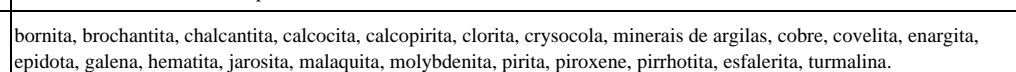 & dionito optifio & & \\
\hline 11 & 1 Antapeceay & & & 3 & 801 & 0 & 0 & 0.16 & & & & & & & & & & & & & 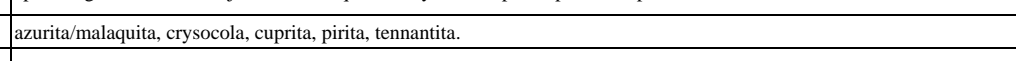 & monzonito, skarm. & & \\
\hline 12 & 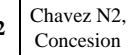 & & & & o & 0 & 0 & 0 & & & sim & 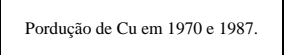 & & & & & & & & & 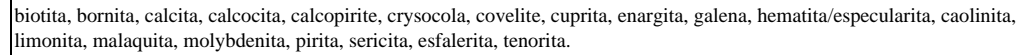 & 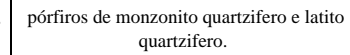 & & 7.1 \\
\hline 13 & Acos & & & 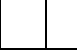 & 0 & 0 & 0 & 0 & & & sim & 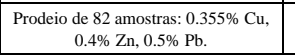 & & & & & & & & & 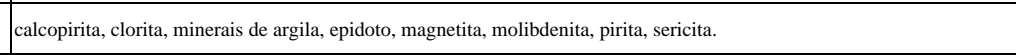 & hometels & & \\
\hline 14 & $\begin{array}{l}A^{A} \\
\text { Thiole }\end{array}$ & & & a & 0 & 0 & 0 & 0 & & & sim & 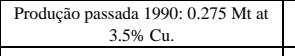 & & & & & & & & & bomita, calcocita, calcopinita, covelita, limonita, magneneita, pritia. & & & \\
\hline 15 & Puauio & El Pruquio & & 19 & 00.22 & 0 & o & $\circ$ & & & $\operatorname{sim}$ & & & & & & & & & & 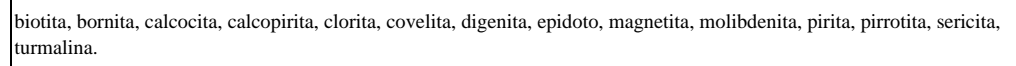 & andesito pơfirio, brecha & granodionitio, tonalitio & ${ }_{18}$ \\
\hline 16 & Eliana & $\begin{array}{l}\text { Quubarad Rio seco } \\
\text { disict }\end{array}$ & & & . & $\circ$ & 0 & 0 & & & sim & 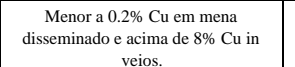 & & & & & & & & & 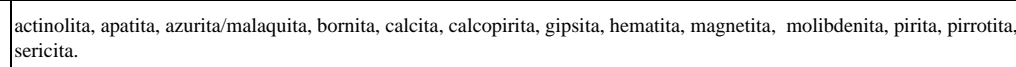 & brecha, gabro-dioiotio, starm & & \\
\hline 17 & Tingo & & & & o & $\circ$ & 0 & 0 & & & sim & & & & & & & & & & 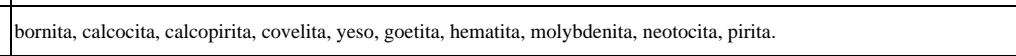 & póffirios diversos & & 2.7 \\
\hline 18 & Almeen & & Ica & 15 & 500.3 & 0.025 & 8 & 0 & & & & & cLosesp-ac & & & qa-orotbe & pycp & py-cplmb & py-cp-mb & & 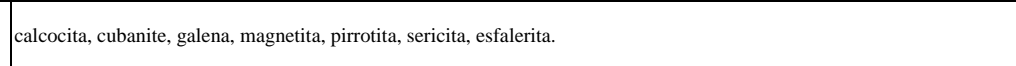 & 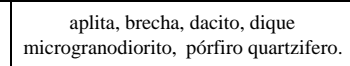 & dioniti, granodionitio & 4 \\
\hline 19 & Los rins & & & 37 & 8.80 .4 & 0 & 0 & 0 & & & & & & & & & & & & & 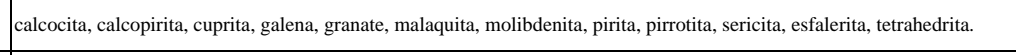 & 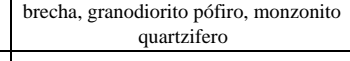 & & \\
\hline 20 & ro Motho & cho, Moro & Junin & 7.5114 & ${ }_{800}^{0.5}$. & 0.02 & & 0 & 1928 & & & 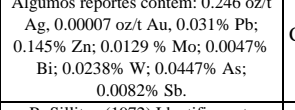 & $\begin{array}{c}\text { closer-act } \\
\text { dp }\end{array}$ & & 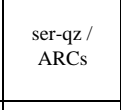 & brent-42 & py<p & 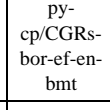 & vep-phblwt & pyc-crmb & 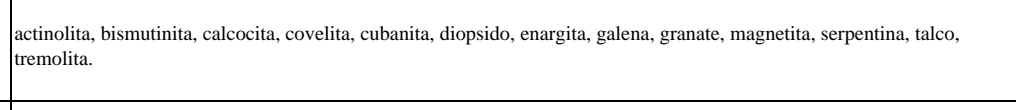 & 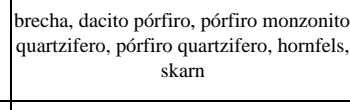 & 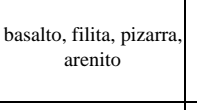 & \\
\hline 21 & 1. Puypley & & & 7 & 0 & 0 & 0 & 0 & & & sim & 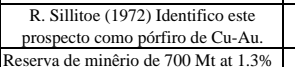 & & & & & & & & & calcita, galen, limonita, prita, sericita & dioritio poffirio, quartzo póffiro & & \\
\hline 22 & Anamina & & & 10 & 0 & 。 & 0 & 0 & 1850 & 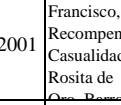 & & 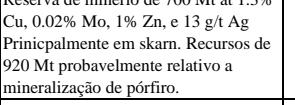 & & & & & & & & & 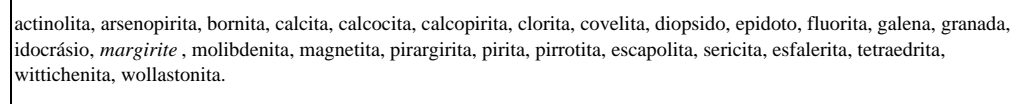 & 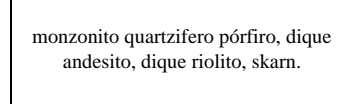 & & \\
\hline 23 & 3 pastrpep & & Aneash & 147715 & 500.5 .5 & 50.053 & & 0 & & & & & closepeptac & & quserer & & py & pyccpmb & pyccp-mb & & 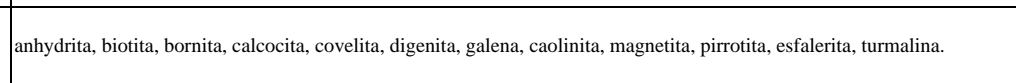 & 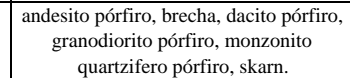 & & 1.8 \\
\hline${ }^{24}$ & Agula & El|gugia & Ancash & . & $\left.4\right|_{0.8}$ & 50.031 & $\circ$ & 0 & & & & & closep & ARCs 42 & ser-qz & berczoot & & 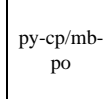 & pycp-mb & appymb & 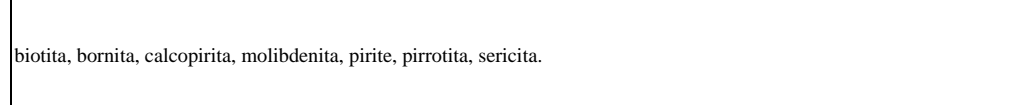 & 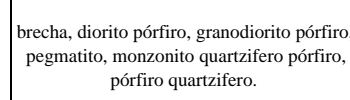 & & \\
\hline 25 & Magistral & & & 2119 & 800.8. & 30.06 & 0 & 0 & & & & & & & & & & & & & 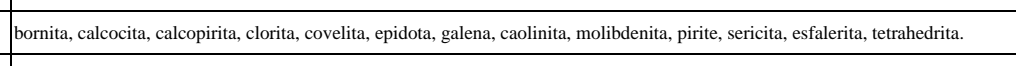 & monzonito quartzifiero pơfifir, skam. & granadionitio, tonalitio & \\
\hline 26 & Micinaullay & & Cajamarca & 2070 & 000.6 & 0.022 & 0.6 & 0.14 & 1960 & & & & cLosepplac & ARCs-qz & qaseressilf & qa-blotort & 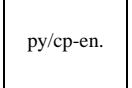 & py-cp & 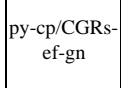 & 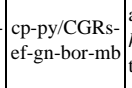 & 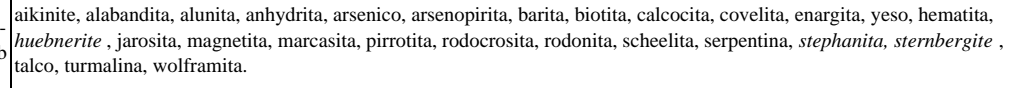 & 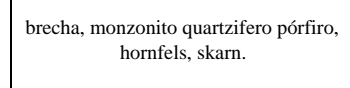 & gerandionitio pófifio & 3.6 \\
\hline 27 & 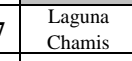 & & & 1 & 0 & 0 & 0 & 0 & & & sim & $0.25 \%$ cu, 0.5 g t t Au. & & & & & & & & & 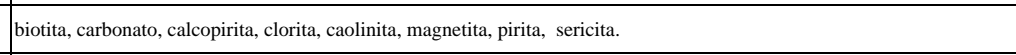 & 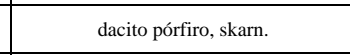 & & \\
\hline 28 & Bicialeno & & & & 050.5 .5 & 0 & 0 & 0.15 & & & & & & & & & & & & & & & & \\
\hline 29 & $\underbrace{\substack{\text { Monga } \\
\text { Cons }}}_{\text {Mins }}$ & & & 16 68 6 & 410.3 & 0 & 0 & 0.79 & 1991 & & sim & & & & & & & & & & 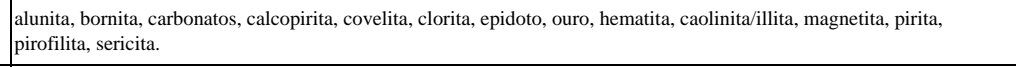 & 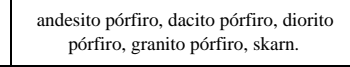 & quartitio, arenisca & \\
\hline 30 & 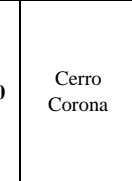 & 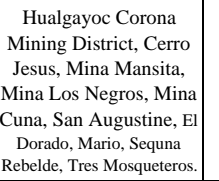 & & 10.517 & 755.5 & & & 1 & & & & & & & & & & & & & 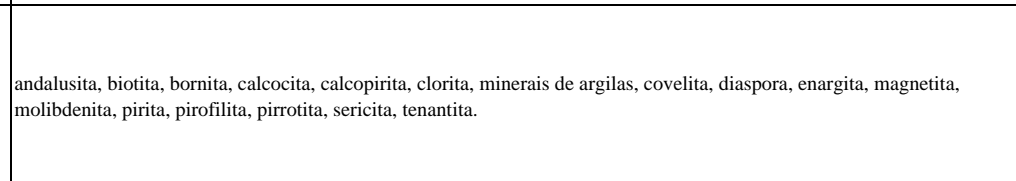 & 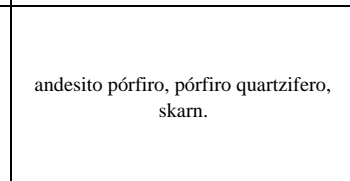 & & \\
\hline 31 & 1. Tanathatay & Sinchao Property & & & 75 0.8.8 & & & 0.3 & 1990 & & sim & & & & & & & & & & aluniat, alcopinita, enargita, ouro, illita, pirita, sericita. & brecha, slam & & 7.1 \\
\hline 32 & 2 La Ganjia & & Cajamarca & 12300 & 0000.5 & 60.01 & 4.2 & 0 & 1969 & & & 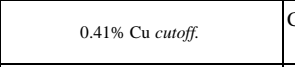 & 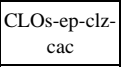 & anlperf-g-didp & qasere-ARCs & & py-met & py-rt & pycp & py & 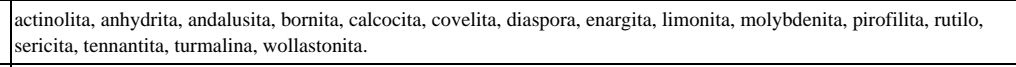 & $\begin{array}{l}\text { brecha, mamolol, porfirio quartifierer, } \\
\text { skam }\end{array}$ & & 15.7 \\
\hline 33 & Cañinaco & & Lambasequere & 1532 & & . & 0 & . & & & & & cLosepe-cad & & quesersilfial & 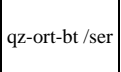 & & 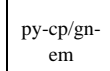 & py-cr-pmbef & cppovymbmem i & 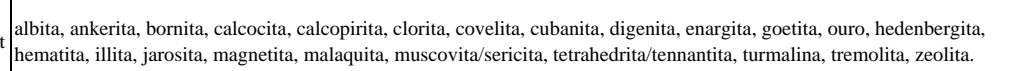 & 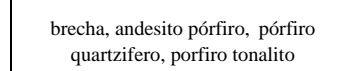 & 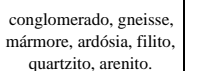 & 7.1 \\
\hline${ }^{34}$ & Paramo & El P Paramo & & & 0 & 0 & 0 & $0^{\circ}$ & & & sim & & & & & & & & & & 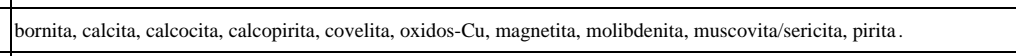 & 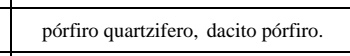 & & \\
\hline 35 & Lav vega & & Cajamanara & & 0 & 0 & 0 & 0 & & La thace & $\operatorname{sim}$ & 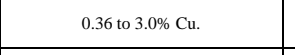 & 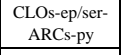 & & qas-sersilif & & $\mathrm{py}$ & py-cp & py-cp-mb & & 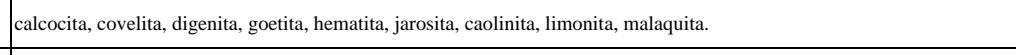 & brecha & & \\
\hline${ }_{36}$ & io Blanco & & & 16 & 0 & 0 & 0 & 0 & 1996 & & $\operatorname{sim}$ & 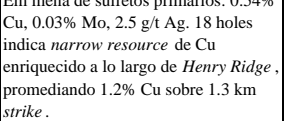 & & & & & & & & & 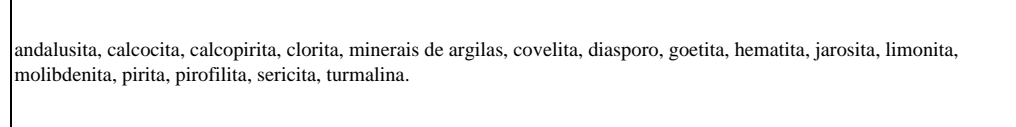 & andesitio pơfirio, brecha, dacito pơfirio. & 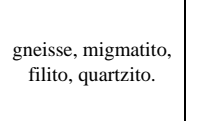 & 3.6 \\
\hline
\end{tabular}


ANEXO 3: Resumo dos tipos de rocha presentes na Jazida de Cuajone

\begin{tabular}{|c|c|c|c|c|c|c|c|}
\hline \multirow{2}{*}{ Código } & \multirow{2}{*}{ Tipo de rocha } & \multirow{2}{*}{ Alteração } & \multicolumn{4}{|c|}{ Categorias } & \multirow{2}{*}{ Outros Minerais } \\
\hline & & & mck & cb & po & сp & \\
\hline E-3 & Andesito & $\mathrm{K}_{(\mathrm{c}) \mathrm{f}}$ & - & - & $\mathrm{T}$ & $\mathrm{T}$ & $\mathrm{mg}^{+}, \pm \mathrm{py} \cong \mathrm{cp} \pm \mathrm{hm}^{=}$ \\
\hline B-3 & Andesito & $\mathrm{K}_{(\mathrm{c})} \mathrm{f}$ & - & - & - & - & $\mathrm{mg}^{+}, \pm \mathrm{py} \geq \mathrm{cp}$, bor $^{=}$ \\
\hline $\mathrm{C}-4$ & Andesito & $K_{(c)} f$ & - & - & - & - & cp, mb, mg, cp \pm bor, c $\overline{\bar{v}}, \mathrm{py}^{=}$ \\
\hline D-5 & Andesito & $\mathrm{K}_{(\mathrm{c}) \mathrm{m}}=\mathrm{P}_{\mathrm{d}-\mathrm{m}}$ & $\mathrm{T} / \mathrm{E}$ & $\mathrm{T}$ & M & M & $\mathrm{py} \cong \mathrm{cp}, \mathrm{mg}$ \\
\hline $\mathrm{F}-2$ & Andesito & $\mathrm{K}_{\mathrm{d}-\mathrm{m}} / \mathrm{P}_{\mathrm{d}-\mathrm{m}}$ & $\mathrm{T}$ & $\mathrm{T}$ & M & M & py > cp, \pm rt-LCX, mḡ, hm-. \\
\hline F-3 & Andesito & $\mathrm{K}_{(\mathrm{c}) \mathrm{d}} / \mathrm{P}_{\mathrm{d}}$ & $\mathrm{T}$ & - & M & E & py, mg, rt-LCX \pm hm, \pm cp, bor ${ }^{-}$cv $^{-}$ \\
\hline E-2 & Andesito & $\mathrm{K}_{(\mathrm{c}) \mathrm{d}} / \mathrm{P}_{\mathrm{d}-\mathrm{m}}$ & $\mathrm{T}$ & - & $\mathrm{T}$ & $\mathrm{T}$ & $\mathrm{mg}^{+}, \pm \mathrm{cp} \geq \mathrm{py}, \mathrm{po}^{=}$ \\
\hline $\mathrm{C}-3$ & Andesito & $\mathrm{K}_{(\mathrm{c}) \mathrm{d}} / \mathrm{P}_{\mathrm{d}-\mathrm{m}}$ & $\mathrm{T}$ & $\mathrm{T}$ & - & $\mathrm{T}$ & $\mathrm{mg}, \mathrm{cp} \cong \mathrm{py}, \mathrm{ef}^{\mathrm{F}}$ \\
\hline D-3 & Andesito & $\mathrm{K}_{(\mathrm{c}) \mathrm{d}} / \mathrm{P}_{\mathrm{d}-\mathrm{m}}$ & - & - & - & - & $\mathrm{cp}^{+}>\mathrm{py}^{-}, \mathrm{LCX}$ \\
\hline $\mathrm{V}-1$ & Andesito & $\mathrm{P}_{\mathrm{d}-\mathrm{m}} / \mathrm{K}_{(\mathrm{c}) \mathrm{m}}$ & E & $\mathrm{T}$ & $\mathrm{F} / \mathrm{M}$ & $\mathrm{F}$ & $\mathrm{py}^{+}>$cp, mg \pm rt-LCX, hm \\
\hline $\mathrm{N}-3$ & Andesito & $\mathrm{P}_{\mathrm{m}} / \mathrm{K}_{(\mathrm{c}) \mathrm{d}}$ & E & $\mathrm{T}$ & $\mathrm{T}$ & E & $\mathrm{py}>\mathrm{cp} \pm \mathrm{mg}$ \\
\hline M-5 & Andesito & $\mathrm{P}_{\mathrm{m}} / \mathrm{K}_{\text {(c)d }}$ & $\mathrm{T} / \mathrm{E}$ & $\mathrm{T}$ & M & $\mathrm{M} / \mathrm{F}$ & $\mathrm{py}^{+} \pm \mathrm{mg}$ \\
\hline B-1 & Andesito & $\mathrm{P}_{\mathrm{d}-\mathrm{m}} / \mathrm{K}_{(\mathrm{c}) \mathrm{i}}$ & $\mathrm{T}$ & $\mathrm{T}$ & $\mathrm{T} / \mathrm{E}$ & E & mg+, py, ср \pm mg-hm, rt. \\
\hline V-3 & Andesito & $\mathrm{P}_{\mathrm{m}-\mathrm{f}} / \mathrm{K}_{(\mathrm{c}) \mathrm{d}}$ & $\mathrm{T}$ & $\mathrm{T}$ & $\mathrm{E} / \mathrm{M}$ & E & py > cp', mg \\
\hline $\mathrm{H}-2$ & Andesito & $\mathrm{P}_{\mathrm{m}-\mathrm{i}} / \mathrm{K}_{(\mathrm{c}) \mathrm{i}}$ & $\mathrm{T}$ & - & $\mathrm{T}$ & $\mathrm{T}$ & mg', hm \pm py, cp, cv, bor, arsenopirita(?) \\
\hline E-1 & Andesito & $\mathrm{P}_{\mathrm{m}} / \mathrm{K}_{\mathrm{i}}$ & $\mathrm{T}$ & - & $\mathrm{T}$ & $\mathrm{T}$ & $\mathrm{cp} \geq \mathrm{py}, \mathrm{mg}, \mathrm{mb}$ \\
\hline $\mathrm{V}-2$ & Andesito & $\mathrm{P}_{\mathrm{d}-\mathrm{m}} / \mathrm{K}_{(\mathrm{c}) \mathrm{i}}$ & $\mathrm{T}$ & - & - & $\mathrm{T}$ & py $>$ cp $=$, mg \\
\hline G-2 & Andesito & $\mathrm{P}_{\mathrm{f}} / \mathrm{K}_{(\mathrm{c}) \mathrm{i}}$ & - & - & $\mathrm{T}$ & $\mathrm{T}$ & $\mathrm{mg}, \mathrm{py} \pm \mathrm{cp}=$ \\
\hline G-1 & Andesito & $\mathrm{P}_{\mathrm{f}} / \mathrm{K}_{(\mathrm{c}) \mathrm{d}}$ & - & - & $\mathrm{T}$ & $\mathrm{T}$ & mg, hm \\
\hline $\mathrm{R}-4$ & Andesito & silf, $P_{d} / K_{i}$ & - & - & - & - & rt-LCX, mg, cp> py, hm, bor, cv \\
\hline $\mathrm{C}-2$ & Andesito & $\mathrm{P}_{\mathrm{f}-\mathrm{m}}$ & $\mathrm{T} / \mathrm{E}$ & - & $\mathrm{T}$ & E & $\mathrm{py} \cong \mathrm{cp}, \mathrm{mb}, \mathrm{mg}, \mathrm{rt}-\mathrm{LCX}$ \\
\hline G-3 & Andesito & $\mathrm{P}_{\mathrm{f}}$ & - & - & $\mathrm{T}$ & $\mathrm{T}$ & $\mathrm{mg}^{+}, \mathrm{py}>\mathrm{cp}, \mathrm{hm}^{=}$ \\
\hline $\mathrm{C}-1$ & Hidrotermalito CBs-ser-cz-CLOs (possível: Andesito) & $\mathrm{P}_{(\mathrm{CBs})}$ & $\mathrm{T}$ & - & $\mathrm{T}$ & $\mathrm{T}$ & $\mathrm{cp}^{-} \cong \mathrm{py}^{-}, \mathrm{rt}, \mathrm{mb}^{+}$ \\
\hline A-1 & Hidrotermalito ARCs-ser-CBs-CLOs (possível: Andesito) & $\mathrm{P}_{\mathrm{f}-\mathrm{m}}$ & - & - & - & - & $\mathrm{py} \cong \mathrm{cp}, \mathrm{mg}$ \\
\hline D-2 & Hidrotermalito ARCs-ser-qz-CLOs (possível: Andesito) & $\mathrm{P}_{\mathrm{f}-\mathrm{m}}$ & - & - & - & - & $\mathrm{cp}>\mathrm{py}, \mathrm{mg}=$ \\
\hline B-2 & Andesito & $P_{d} / F_{?(\text { silf })}$ & $\mathrm{T}$ & $\mathrm{T}$ & $\mathrm{T}$ & $\mathrm{T}$ & py > cp, mg, rt \\
\hline M-4 & Andesito & $\operatorname{Silf}_{\mathrm{m}(\mathrm{F} ?)}=\mathrm{P}_{\mathrm{d}}$ & $\mathrm{T}$ & - & E & E & $\mathrm{py}^{+}, \mathrm{rt}-\mathrm{LCX}, \mathrm{cp}$ \\
\hline
\end{tabular}




\begin{tabular}{|c|c|c|c|c|c|c|c|}
\hline \multirow{2}{*}{ Código } & \multirow{2}{*}{ Tipo de rocha } & \multirow{2}{*}{ Alteração } & \multicolumn{4}{|c|}{ Categorias } & \multirow{2}{*}{ Outros Minerais } \\
\hline & & & mck & cb & po & $\mathbf{c p}$ & \\
\hline L-3 & Riolito & $F_{f}$ & $\mathrm{~T}$ & - & $\mathrm{T}$ & $\mathrm{T}$ & py $>$ cp, \pm cv \pm bor $=$ \\
\hline $\mathrm{L}-2$ & Riolito & $F_{f}$ & $\mathrm{~T}$ & - & - & $\mathrm{T}$ & py $>$ cp, \pm bor $=$, cc $=$ \\
\hline $\mathrm{K}-2$ & Riolito & $\mathrm{F}_{\mathrm{d}-\mathrm{m}}$ & - & - & $\mathrm{T}$ & - & $\mathrm{py}^{+}>$cp, CGRs(?), bor, cv, gl, ef. \\
\hline L-1 & Riolito & $F_{f-m}$ & $\mathrm{~T}$ & - & - & $\mathrm{T}$ & py > cp $=$ \\
\hline M-3 & Riolito & $F_{f}$ & - & - & $\mathrm{T}$ & $\mathrm{T}$ & LCX, py $>$ cp $=$, cv $=$, bor $=$ \\
\hline $\mathrm{N}-1$ & Riolito & $F_{f-m}$ & $\mathrm{~T}$ & - & $\mathrm{T}$ & $\mathrm{T}$ & $\mathrm{py}^{+}>\mathrm{cp}=$, rt-LCX, \pm cv, cc, bor, CGRs(?) \\
\hline $\mathrm{M}-2$ & Riolito & $F_{f}$ & - & - & - & - & py > cp, rt-LCX, bor $\overline{\overline{1}}$, cv $=$, cc $=$ \\
\hline O-1 & Pórfido alterado a ser-qz- ARCs (possível: Riolito) & $F_{f-m}$ & M & $\mathrm{T}$ & M & A & py $\geq$ cp \\
\hline K-1 & Pórfido alterado a ser-qz-py (possível: Riolito) & $F_{f}$ & $\mathrm{~T}$ & - & $\mathrm{T}$ & $\mathrm{T}$ & py+, rt-LCX, bor, cv, CGRs(?) arsenopirita(?) \\
\hline Q-1 & Hidrotermalito de ser-cz-CBs-py (possível: Riolito) & $\mathrm{F}_{\mathrm{f}}$ & $\mathrm{T} / \mathrm{E}$ & $\mathrm{T}$ & $\mathrm{E}$ & $\mathrm{M}$ & $\mathrm{py} \cong \mathrm{cp} \pm$ bor, $\mathrm{mb}$, ef \\
\hline M-1 & Hidrotermalito de ser-cz \pm ARCs (possível: Riolito) & $F_{f}$ & - & - & - & - & rt-LCX, py ${ }^{+}, \mathrm{cv}^{=}, \mathrm{cc}^{=}$ \\
\hline $\mathrm{N}-2$ & Hidrotermalito ser- CBs-qz- CLOs (possível: Riolito?) & $\mathrm{F}_{\mathrm{m}}=\mathrm{P}_{\mathrm{d}-\mathrm{m}}$ & $\mathrm{E} / \mathrm{T}$ & $\mathrm{T}$ & $\mathrm{E}$ & $\mathrm{M}$ & $\mathrm{py}^{+}>\mathrm{cp}, \mathrm{rt}-\mathrm{LCX} \pm \mathrm{mg}(?)$ \\
\hline $\mathrm{I}-2$ & Qz latito & $P_{(C B s) d-m}$ & - & - & - & - & py > cp, rt-LCX, bor $\overline{\bar{r}}(?)$ \\
\hline A-2 & Qz latito & $\mathrm{P}_{(\mathrm{CBs})}$ & - & - & - & - & rt, py \\
\hline A-3 & Qz latito & $\mathrm{P}_{(\mathrm{CBs})}$ & - & - & - & - & py, rt-LCX \\
\hline $\mathrm{R}-2$ & Qz latito & $\mathrm{P}_{\mathrm{d}}$ & - & - & - & - & LCX, mg-hm, cp, py, ef \\
\hline $\mathrm{I}-1$ & Qz latito & Ser/P $\mathrm{P}_{(\mathrm{CBs}) \mathrm{m}-\mathrm{d}}$ & - & - & - & - & $\mathrm{py} \cong \mathrm{cp} \pm$ bor $\pm \mathrm{rt}-\mathrm{LCX} \pm \mathrm{hm} \pm \mathrm{mg} \pm \mathrm{c} \overline{\overline{\mathrm{v}}} \pm \mathrm{dg}(?)$ \\
\hline $\mathrm{I}-3$ & Qz latito & $\mathrm{P}_{(\mathrm{CBs})} / \mathrm{Ser}_{\mathrm{m}-\mathrm{d}}$ & - & $\mathrm{T}$ & $\mathrm{T}$ & $\mathrm{T}$ & ср $>$ py, rt-LCX \pm ef \pm gl \pm mg \pm hm \\
\hline $\mathrm{I}-4$ & Qz latito & Ser / $P_{(\mathrm{CBs}) \mathrm{d}-\mathrm{m}}$ & $\mathrm{T}$ & $\mathrm{T}$ & $\mathrm{T}$ & $\mathrm{T}$ & py, cp, rt-LCX, mg-hm, ef(?) \\
\hline $\mathrm{K}-3$ & Andesito-II & $\mathrm{P}_{\mathrm{m}} / \mathrm{K}_{\mathrm{m}-\mathrm{d}(?)}$ & $\mathrm{T}$ & - & $\mathrm{T}$ & $\mathrm{T}$ & py $>$ cp, mg, rt-LCX \pm hm \\
\hline D-6 & Latito & $\mathrm{K}_{\mathrm{d}}=\mathrm{P}_{\mathrm{d}}$ & $\mathrm{T}$ & - & $\mathrm{T}$ & $\mathrm{T}$ & 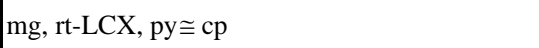 \\
\hline $\mathrm{T}-3$ & Micro-granodiorito porfiritico & $\mathrm{P}_{\mathrm{d}} / \mathrm{K}_{\mathrm{i}(?)}$ & $\mathrm{T}$ & $\mathrm{T}$ & - & $\mathrm{T}$ & $\mathrm{cp} \geq \mathrm{py}, \mathrm{mg} \pm \mathrm{rt}-\mathrm{LCX} \pm \mathrm{hm} \pm \mathrm{mb} \pm$ bor $\overline{\bar{r}}$ \\
\hline S-3 & Micro-granodiorito porfirítico & $\mathrm{P}_{\mathrm{d}} / \mathrm{K}_{\mathrm{i}(?)}$ & - & - & - & - & $\mathrm{cp}^{+}>\mathrm{py}^{-} \cong \mathrm{mg}^{-}$ \\
\hline $\mathrm{T}-2$ & Micro-granodiorito porfiritico & $\mathrm{P}_{\mathrm{m}} / \mathrm{K}_{\mathrm{i}}$ & $\mathrm{T}$ & - & $\mathrm{T}$ & $\mathrm{T}$ & $\mathrm{cp}>\mathrm{py}, \mathrm{mb} \pm \mathrm{rt}$ \\
\hline $\mathrm{J}-3$ & Micro granodiorito porfiritico- Micro tonalito porfiritico(?) & $\mathrm{F}_{\mathrm{d}} / \mathrm{P}_{\mathrm{i}}$ & $\mathrm{T}$ & $\mathrm{T}$ & $\mathrm{T} / \mathrm{E}$ & $\mathrm{E}$ & py, cp, rt, mg, bor $\overline{\bar{c}}$ \\
\hline $\mathrm{J}-4$ & $\begin{array}{l}\text { Pórfiro alterado a ARCs-ser-qz, CLOs-CBs (possível: Micro granodiorito } \\
\text { porfiritico-Micro tonalito porfirítico(?)) }\end{array}$ & $\mathrm{F}_{\mathrm{m}-\mathrm{f}} / \mathrm{P}_{\mathrm{d}}$ & $\mathrm{T}$ & $\mathrm{T} / \mathrm{E}$ & $\mathrm{F}$ & $\mathrm{F}$ & py > cp, mg, rt-LCX \\
\hline $\mathrm{J}-2$ & $\begin{array}{l}\begin{array}{l}\text { Hidrotermalito de ser-cz-py (possível: Micro granodiorito porfirítico-mici } \\
\text { tonalito porfirítico(?)) }\end{array} \\
\end{array}$ & $\mathrm{P}_{\mathrm{f}-\mathrm{m}} / \mathrm{F}_{(?)}$ & $\mathrm{T}$ & $\mathrm{T}$ & $\mathrm{E}$ & $\mathrm{E}$ & $\mathrm{mg}^{+}, \mathrm{LCX}, \mathrm{py}>\mathrm{cp}, \mathrm{hm}^{=}$ \\
\hline
\end{tabular}




\begin{tabular}{|c|c|c|c|c|c|c|c|}
\hline \multirow{2}{*}{ Código } & \multirow{2}{*}{ Tipo de rocha } & \multirow{2}{*}{ Alteração } & \multicolumn{4}{|c|}{ Categorias } & \multirow{2}{*}{ Outros Minerais } \\
\hline & & & mck & cb & po & $\mathbf{c p}$ & \\
\hline $\mathrm{J}-1$ & $\begin{array}{l}\text { Hidrotermalito de ser-cz-py (possível: Micro granodiorito porfirítico- } \\
\text { Micro tonalito porfirítico(?)) }\end{array}$ & $F_{f}$ & $\mathrm{~T} / \mathrm{E}$ & $\mathrm{T}$ & $\mathrm{T} / \mathrm{E}$ & $\mathrm{E}$ & $\mathrm{py}^{-} \geq \mathrm{cp}^{-}, \mathrm{rt}-\mathrm{LCX} \pm \mathrm{cv}$ \\
\hline $\mathrm{R}-3$ & Micro-tonalito porfirítico & $\mathrm{P}_{\mathrm{d}} / \mathrm{K}_{\mathrm{i}}$ & $\mathrm{T}$ & - & - & $\mathrm{T}$ & $\mathrm{cp}^{+}>\mathrm{py}^{ }, \mathrm{mb}, \mathrm{rt}-\mathrm{LCX}$. \\
\hline P-3 & Pórfiro I (micro quartzo monzonito - micro monzogranito) & $\mathrm{P}_{\mathrm{d}} / \mathrm{K}_{\mathrm{i}(?)}$ & $\mathrm{T}$ & - & $\mathrm{T} / \mathrm{E}$ & $\mathrm{E}$ & py $>$ cp $\pm \mathrm{rt} \pm \mathrm{mg}$ \\
\hline S-1 & Pórfiro I (micro quartzo monzonito - micro monzogranito) & $\mathrm{P}_{\mathrm{d}} / \mathrm{K}_{\mathrm{i}}$ & $\mathrm{T}$ & - & $\mathrm{T}$ & $\mathrm{T}$ & ср > py \pm rt-LCX, mb \\
\hline $\mathrm{P}-4$ & Pórfiro I (micro quartzo monzonito - micro monzogranito) & $\mathrm{P}_{\mathrm{d}} / \mathrm{K}_{\mathrm{i}(?)}$ & - & - & - & - & $\mathrm{cp}^{+}>$py, rt-LCX \\
\hline $\mathrm{Q}-2$ & Pórfiro I (micro quartzo monzonito - micro monzogranito) & $\mathrm{P}_{\mathrm{d}} / \mathrm{K}_{\mathrm{i}}$ & - & - & - & - & $\mathrm{cp}^{++}>$py-, rt, mb \\
\hline $\mathrm{R}-1$ & Pórfiro I (micro quartzo monzonito - micro monzogranito) & $\mathrm{K}_{\mathrm{i}}-\mathrm{P}_{\mathrm{i}} / \operatorname{silf}_{(?)}$ & - & - & - & - & cp, py, mb \pm rt-LCX, \\
\hline Q-3 & Pórfiro-II (micro tonalito - micro leucoquartzo diorito) & $\mathrm{K}_{\mathrm{d}} / \mathrm{P}_{\mathrm{d}-\mathrm{i}}$ & $\mathrm{E}$ & $\mathrm{T}$ & $\mathrm{E} / \mathrm{M}$ & M & $\mathrm{mb}, \mathrm{py}>\mathrm{cp}$ \\
\hline O-3 & Pórfiro-II (micro tonalito - micro leucoquartzo diorito) & $\mathrm{K}_{\mathrm{i}} / \mathrm{P}_{\mathrm{d}-\mathrm{m}}$ & $\mathrm{T}$ & - & - & $\mathrm{T}$ & $\mathrm{cp}^{+}>\mathrm{py}, \mathrm{rt}, \mathrm{mb}$ \\
\hline D-4 & Pórfiro-II (micro tonalito - micro leucoquartzo diorito) & $\mathrm{K}_{\mathrm{i}} / \mathrm{P}_{\mathrm{i}}$ & - & - & - & - & $\mathrm{py}^{-}>\mathrm{cp}^{-} \pm \mathrm{mg}, \mathrm{rt}, \mathrm{LCX}$ \\
\hline $\mathrm{P}-2$ & Pórfiro-II (micro tonalito - micro leucoquartzo diorito) & $\mathrm{K}_{\mathrm{i}-\mathrm{P}-\mathrm{i}} / \mathrm{silf}-\mathrm{F}_{\mathrm{i}(?)}$ & - & - & - & - & $\mathrm{cp}^{+}>\mathrm{py}^{-} \pm \mathrm{rt} \pm$ bor \\
\hline $\mathrm{U}-3$ & Pórfiro-II (micro tonalito - micro leucoquartzo diorito) & $\mathrm{K}_{\mathrm{i}(?)}=\mathrm{P}_{\mathrm{i}} / \mathrm{F}_{\mathrm{i}}$ & $\mathrm{T} / \mathrm{E}$ & $\mathrm{T}$ & $\mathrm{T}$ & $\mathrm{E}$ & py > cp, mb, rt-LCX \\
\hline $\mathrm{H}-4$ & Pórfiro-II (micro tonalito - micro leucoquartzo diorito) & silf - $\mathrm{P}_{(\mathrm{CBs}) \mathrm{m}}$ & $\mathrm{T}$ & - & $\mathrm{T}$ & $\mathrm{T} / \mathrm{E}$ & py > cp \pm rt, hm, bor $=$ \\
\hline $\mathrm{O}-2$ & Pórfiro-II (micro tonalito - micro leucoquartzo diorito) & $\mathrm{P}_{\mathrm{m}}-\mathrm{F}_{\mathrm{d}}$ & $\mathrm{T}$ & - & $\mathrm{T}$ & $\mathrm{T}$ & cp > py, mb, hm \\
\hline $\mathrm{T}-1$ & Pórfiro alt. a qz-ARCs-ser-CBs \pm rt (possível: Pórfiro-II) & $\mathrm{P}_{\mathrm{m}}-\mathrm{F}_{\text {?(sil) }}$ & $\mathrm{T}$ & $\mathrm{T}$ & $\mathrm{T}$ & $\mathrm{T}$ & $\mathrm{cp} \cong \mathrm{py}, \mathrm{rt}-\mathrm{LCX}, \mathrm{mb}$ \\
\hline $\mathrm{S}-2$ & Pórfido silicificado (possível: Pórfiro-II) & $\mathrm{P}_{\mathrm{d}}-\mathrm{F}_{?(\text { sil }}$ & - & - & - & - & cp > py, rt-LCX, mg-hm \\
\hline $\mathrm{U}-2$ & Pórfiro-II (micro tonalito - micro leucoquartzo diorito) & $\mathrm{F}_{\mathrm{d} ?}-\mathrm{P}_{\mathrm{d}} /$ silf & $\mathrm{T}$ & - & $\mathrm{T}$ & $\mathrm{E} / \mathrm{T}$ & сp $\geq$ py, rt-LCX, mb \\
\hline U-1 & Pórfiro alt. a ser-qz-CLOs-CBs-ARCs (possível: Pórfiro-II) & $\mathrm{F}_{\mathrm{f}}=\mathrm{P}_{\mathrm{d}}$ & $\mathrm{E} / \mathrm{T}$ & $\mathrm{T}$ & $\mathrm{T} / \mathrm{E}$ & $\mathrm{E} / \mathrm{M}$ & cp > py, rt-LCX \\
\hline $\mathrm{P}-1$ & Pórfiro alt. a qz-ser (possível: Pórfiro-II) & $\mathrm{F}_{\mathrm{m}}-\mathrm{P}_{\mathrm{i}}$ & - & - & - & - & сp > py, rt-LCX, mg, mb \\
\hline D-1 & Pórfiro alt. a ser-qz-py (possível: Pórfiro-II) & $\mathrm{F}_{\mathrm{f}} / \mathrm{Pi}_{(\mathrm{CBs})}$ & - & - & - & - & py > cp, mb, LCX \pm bor \pm cv \pm hm(?) \\
\hline $\mathrm{H}-1$ & Hidrotermalito FPKs-ser, qz \pm rt & Kf & $\mathrm{T}$ & - & $\mathrm{T}$ & $\mathrm{T}$ & 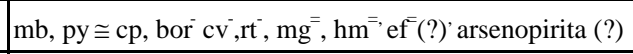 \\
\hline $\mathrm{F}-1$ & Hidrotermalito de FPKs(?), ser, qz, CLOs-CBs-ep & $\mathrm{K}_{\mathrm{i}(?)}=\mathrm{P}_{\mathrm{i}} / \mathrm{F}_{\mathrm{i}}$ & $\mathrm{T} / \mathrm{E}$ & $\mathrm{T}$ & $\mathrm{M}$ & $\mathrm{F}$ & py > cp', rt-LCX \\
\hline H-3 & Micro-brecha & $\mathrm{P}_{(\mathrm{CBs}) \mathrm{m}-\mathrm{d}}$ & $\mathrm{T}$ & - & - & $\mathrm{T}$ & py > cp-e ef(?), hm(?) \\
\hline
\end{tabular}




\section{ANEXO 4}

\section{PERFIS INDICANDO TIPOS DE ROCHA}

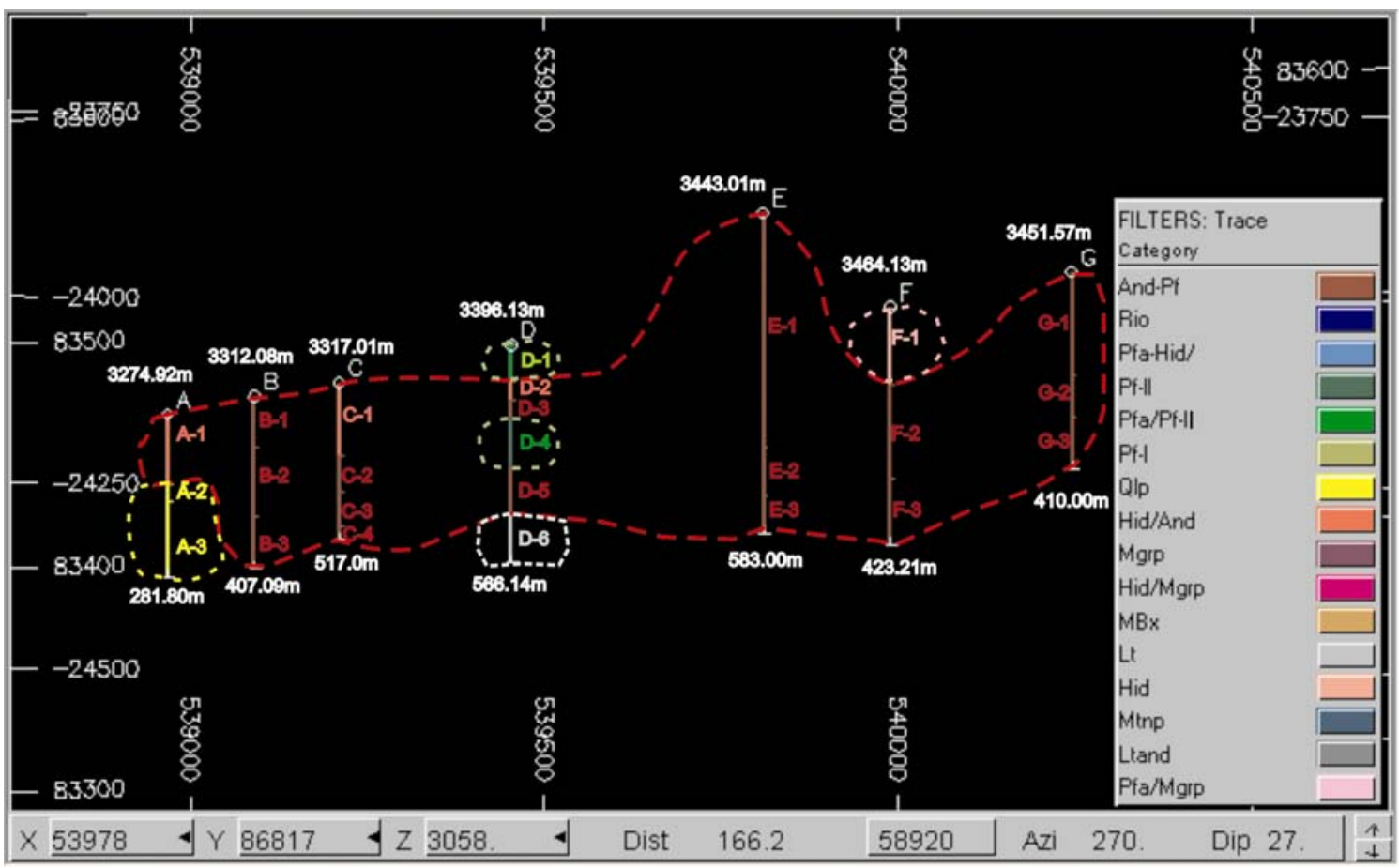

Anexo 4.1: Perfil 1 com seus respectivos furos de sondagem A-G mostrando os tipos de rochas presentes. Cota e profundidade na parte superior e inferior de cada furo de sondagem. Ver abreviaturas no Anexo 1.

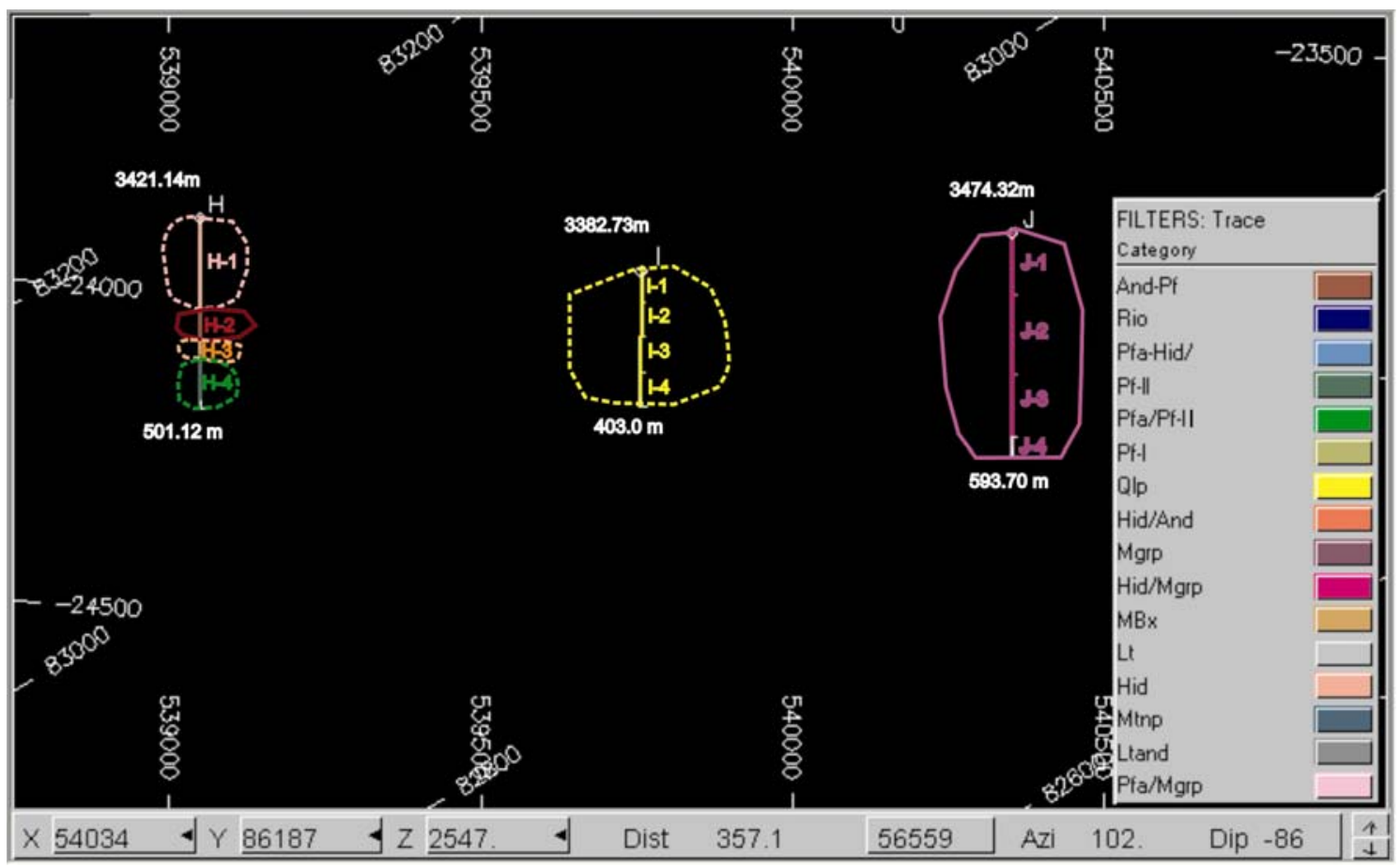

Anexo 4.2: Perfil 2 com seus respectivos furos de sondagem H, I, J mostrando os tipos de rochas presentes. Cota e profundidade na parte superior e inferior de cada furo de sondagem. Ver abreviaturas no Anexo 1. 


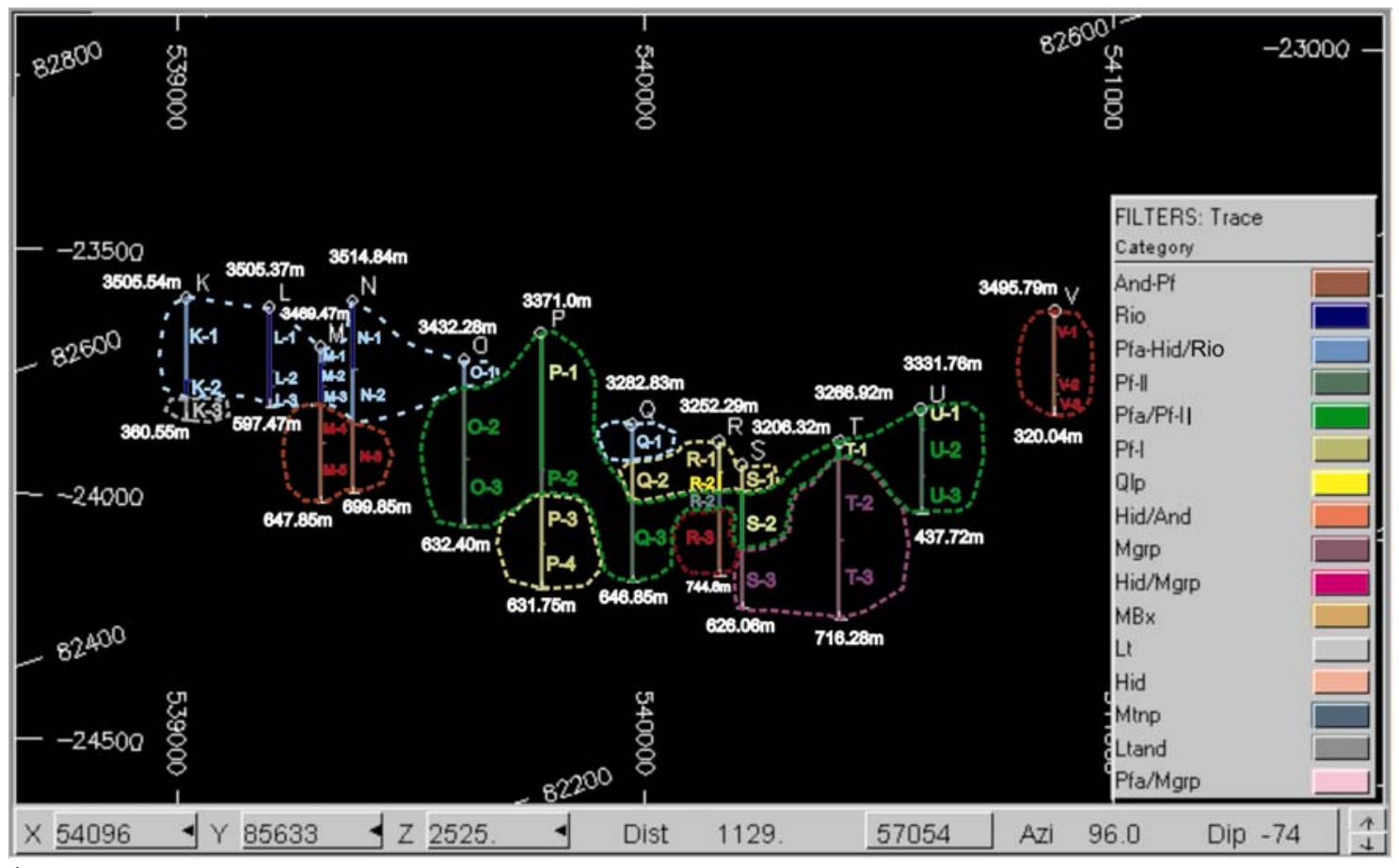

Anexo 4.3: Perfil 3 com seus respectivos furos de sondagem $\mathrm{K}-\mathrm{V}$, mostrando os tipos de rochas presentes. Cota e profundidade na parte superior e inferior de cada furo de sondagem. Ver abreviaturas no Anexo 1. 
ANEXO 6

PERFIS INDICANDO OS TIPOS DE ALTERAÇÃO HIDROTERMAL

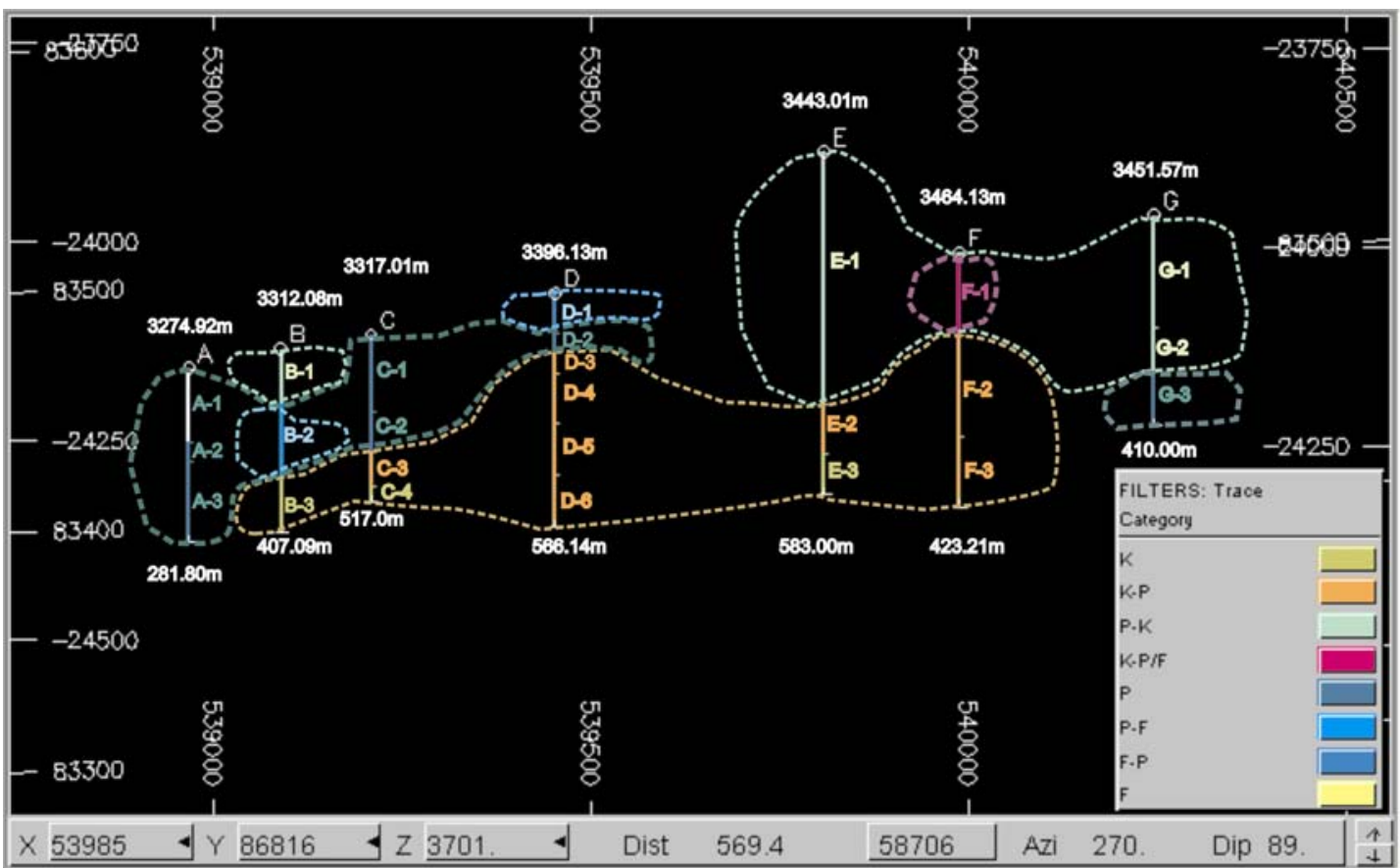

Anexo 6.1: Perfil 1 com seus respectivos furos de sondagem $A-G$, indicando os tipos de alterações hidrotermais presentes na jazida de Cuajone. Cota e profundidade na parte superior e inferior de cada furo de sondagem. Ver abreviaturas dos tipos de rochas e alterações no Anexo 1.

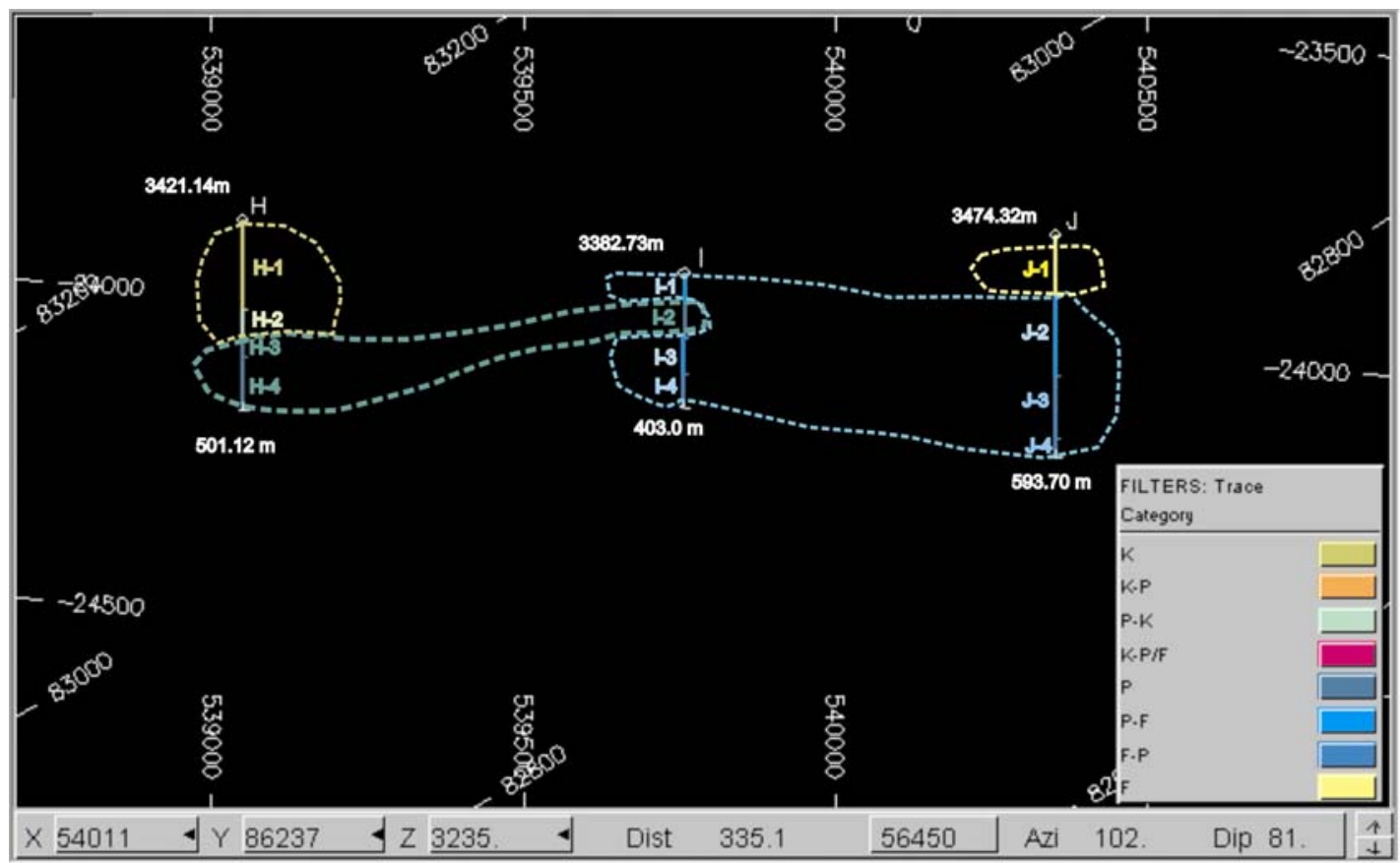

Anexo 6.2: Perfil 2 com seus respectivos furos de sondagem H, I, J indicando os tipos de alterações hidrotermais presentes na jazida de Cuajone. Cota e profundidade na parte superior e inferior de cada furo de sondagem. Ver abreviaturas dos tipos de rochas e alterações no Anexo 1. 


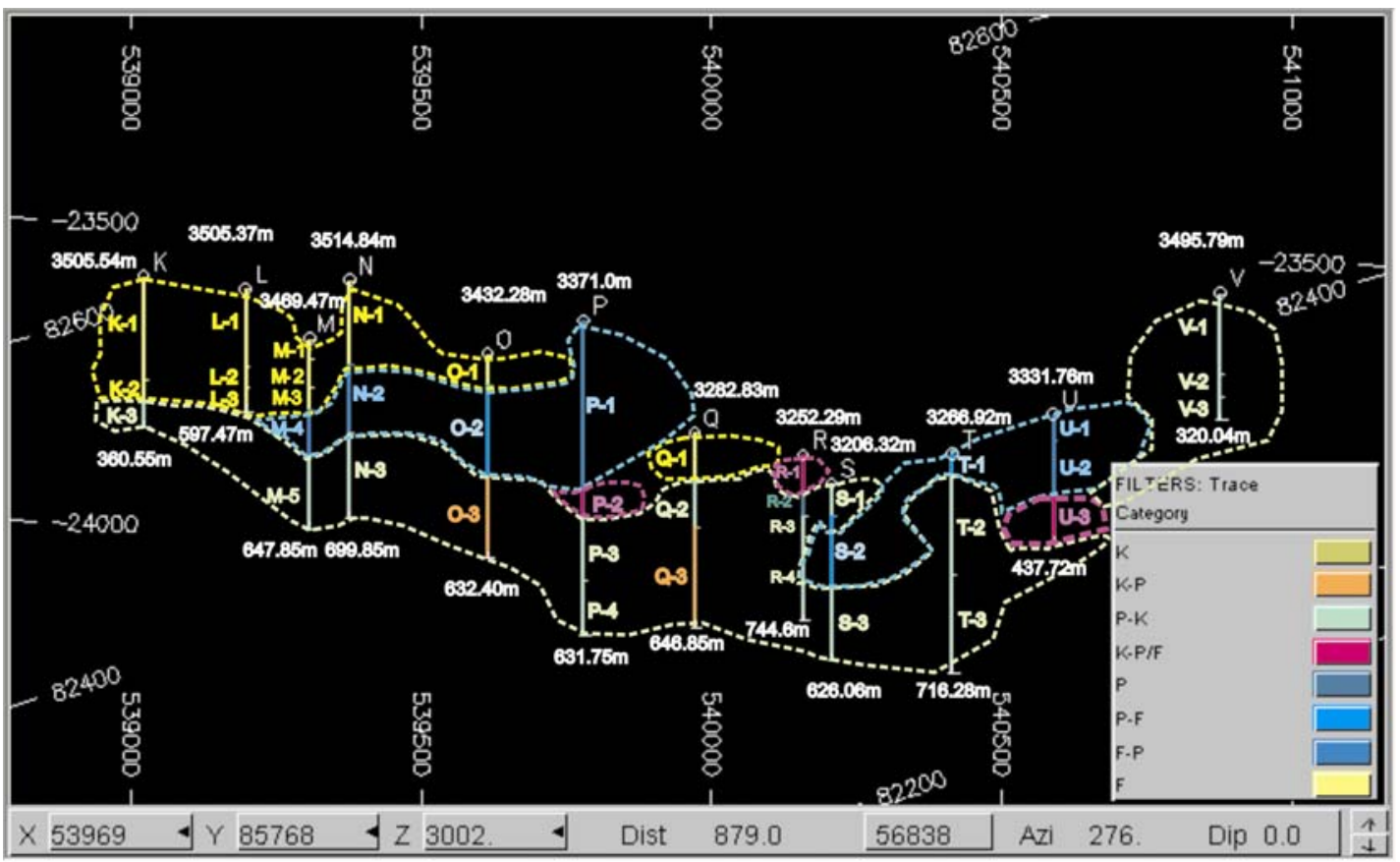

Anexo 6.3: Perfil 3 com seus respectivos furos de sondagem $\mathrm{K}-\mathrm{V}$, indicando os tipos de alterações hidrotermais presentes na jazida de Cuajone. Cota e profundidade na parte superior e inferior de cada furo de sondagem. Ver abreviaturas dos tipos de rochas e alterações no Anexo 1. 
ANEXO 5: Síntese destacando as assembléias minerais na Jazida de Cuajone

\begin{tabular}{|c|c|c|c|c|c|c|c|c|c|c|c|c|c|c|c|}
\hline \multirow{2}{*}{ Perfil } & \multirow{2}{*}{ Codigo } & \multirow{2}{*}{ Alteração } & \multirow{2}{*}{ Mineralogia } & \multirow{2}{*}{ Tipo de rocha } & \multicolumn{4}{|c|}{ Ocorrência } & \multirow{2}{*}{$\begin{array}{c}\text { Ocorrência } \\
\text { Total }\end{array}$} & \multirow{2}{*}{$\begin{array}{c}\mathrm{N}^{\circ} \mathrm{de} \\
\text { inclusões }\end{array}$} & \multicolumn{4}{|c|}{ Categorias } & \multirow{2}{*}{ Outros Minerais } \\
\hline & & & & & mok & cb & po & ср & & & mck & cb & po & ср & \\
\hline 1 & E-3 & $\mathrm{K}_{(\mathrm{c}) \mathrm{f}}$ & bt \pm anh \pm ys(?), CLOs \pm ep & Andesito & & & 2 & 1 & 3 & 2 & - & - & $\mathrm{T}$ & $\mathrm{T}$ & $\mathrm{mg}^{+}, \pm \mathrm{py} \cong \mathrm{cp} \pm \mathrm{hm}^{=}$ \\
\hline 2 & $\mathrm{H}-1$ & Kf & FPKs-ser, qz $\pm \mathrm{rt}$ & Hidrotermalito FPKs-ser, cz \pm rt & 2 & & 5 & 5 & 12 & 7 & $\mathrm{~T}$ & - & $\mathrm{T}$ & $\mathrm{T}$ & 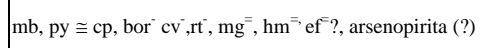 \\
\hline 1 & B-3 & $\mathrm{K}_{(\mathrm{c})} \mathrm{f}$ & bt, CLOs-CBs $\pm e p \pm a n h{ }^{\prime}$, qz, ZEs(?), \pm ser & Andesito & & & & & & & - & - & - & - & $\mathrm{mg}^{+}, \pm \mathrm{py} \geq \mathrm{cp}$, bor $^{=}$ \\
\hline 1 & C-4 & $\mathrm{K}_{(\mathrm{c})} \mathrm{f}$ & bt, CLOs-CBs- ARCs, qz, ZEs(?), \pm ser & Andesito & & & & & & & - & - & 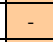 & - & $\mathrm{cp}, \mathrm{mb}, \mathrm{mg}, \mathrm{cp}, \pm$ bor, $\mathrm{cv}=\mathrm{py}{ }^{=}$ \\
\hline 3 & Q-3 & $\mathrm{K}_{\mathrm{d}} / \mathrm{P}_{\mathrm{d}-\mathrm{i}}$ & qz, qz-FPKs, CLOs-ep-CBs & Pórfiro-II (micro tonalito - micro leucoquartzo diorito) & 16 & 3 & 24 & 28 & 71 & 39 & $\mathrm{E}$ & $\mathrm{T}$ & $\mathrm{E} / \mathrm{M}$ & M & mb, py $>$ cp \\
\hline 1 & D-5 & $\mathrm{K}_{(\mathrm{c}) \mathrm{m}}=\mathrm{P}_{\mathrm{d}-\mathrm{m}}$ & bt, FPKs-qz, CLOs \pm anh \pm ser \pm CBs \pm Zes(?) & Andesito & 11 & 6 & 29 & 26 & 72 & 41 & $\mathrm{~T} / \mathrm{E}$ & $\mathrm{T}$ & M & $\mathrm{M}$ & $\mathrm{py} \cong \mathrm{cp}, \mathrm{mg}$ \\
\hline 1 & $\mathrm{~F}-2$ & $\mathrm{~K}_{\mathrm{d}-\mathrm{m}} / \mathrm{P}_{\mathrm{d}-\mathrm{m}}$ & bt, CLOs, qz, FPKs, ser, \pm ep \pm anh \pm ARCs & Andesito & 3 & 8 & 32 & 30 & 73 & 35 & $\mathrm{~T}$ & $\mathrm{~T}$ & M & M & $\mathrm{py}>\mathrm{cp}, \pm \mathrm{rt}-\mathrm{LCX}, \mathrm{mg}, \mathrm{hm}$. \\
\hline 1 & F-3 & $\mathrm{K}_{(\mathrm{c}) \mathrm{d}} / \mathrm{P}_{\mathrm{d}}$ & bt, CLOs, qz \pm anh \pm ep \pm ZEs(?) & Andesito & 7 & & 26 & 14 & 47 & 29 & $\mathrm{~T}$ & - & $\mathrm{M}$ & $\mathrm{E}$ & $\mathrm{py}, \mathrm{mg}, \mathrm{rt}-\mathrm{LCX} \pm \mathrm{hm}, \pm \mathrm{cp} \mathrm{p}^{-}$,or, $\mathrm{cv}^{-}$ \\
\hline 1 & $\mathrm{E}-2$ & $\mathrm{~K}_{(c) \mathrm{d}} / \mathrm{P}_{\mathrm{d}-\mathrm{m}}$ & bt, cz-CLOs-ARCs, \pm ep, CBs, anh, FPKs & Andesito & 1 & & 2 & 2 & 5 & 3 & $\mathrm{~T}$ & - & $\mathrm{T}$ & $\mathrm{T}$ & $\mathrm{mg}^{+}, \pm \mathrm{cp} \geq \mathrm{py}, \mathrm{po}^{=}$ \\
\hline 1 & D-6 & $\mathrm{K}_{\mathrm{d}}=\mathrm{P}_{\mathrm{d}}$ & FPKs, CLOs-CBs-ep-qz \pm ser & Latito & 5 & & 6 & 8 & 19 & 11 & $\mathrm{~T}$ & - & $\mathrm{T}$ & $\mathrm{T}$ & $\mathrm{mg}, \mathrm{rt}-\mathrm{LCX}, \mathrm{py} \cong \mathrm{cp}$ \\
\hline 1 & C-3 & $\mathrm{K}_{(\mathrm{t}) \mathrm{d}} / \mathrm{P}_{\mathrm{d}-\mathrm{m}}$ & bt, FPKs, CLOs, CBs, ser, \pm ep \pm ARCs \pm Zes(?) & Andesito & 1 & 1 & & 2 & 4 & 2 & $\mathrm{~T}$ & $\mathrm{~T}$ & - & $\mathrm{T}$ & $\mathrm{mg}, \mathrm{cp} \cong \mathrm{py}, \mathrm{ef}^{=}$ \\
\hline 3 & $0-3$ & $\mathrm{~K}_{\mathrm{i}} / \mathrm{P}_{\mathrm{d}-\mathrm{m}}$ & FPKs-qz, qz, CLOs \pm ep \pm CBs & Pórfiro-II (micro tonalito - micro leucoquartzo diorito) & 2 & & & 2 & 4 & 2 & $\mathrm{~T}$ & - & - & $\mathrm{T}$ & $\mathrm{cp}^{+}>\mathrm{py}, \mathrm{rt}, \mathrm{mb}$ \\
\hline 1 & D-4 & $\mathrm{K}_{\mathrm{i}} / \mathrm{P}_{\mathrm{i}}$ & qz-FPKs, ser, CBs, mus, CLOS \pm ARCs & Pórfiro-II (micro tonalito - micro leucoquartzo diorito) & & & & & & & - & - & - & - & $\mathrm{py}^{-}>\mathrm{cp}^{-} \pm \mathrm{mg}, \mathrm{rt}, \mathrm{LCX}$ \\
\hline 1 & D-3 & $\mathrm{K}_{(\mathrm{t}) \mathrm{d}} / \mathrm{P}_{\mathrm{d}-\mathrm{m}}$ & bt, qz, CLOs, ser, CBs \pm ep \pm FPKs(?) & Andesito & & & & & & & - & - & - & - & $\mathrm{cp}^{+}>\mathrm{py}^{-}, \mathrm{LCX}$. \\
\hline 3 & $\mathrm{~V}-1$ & $\mathrm{P}_{\mathrm{d}-\mathrm{m}} / \mathrm{K}_{(\mathrm{c}) \mathrm{m}}$ & CLOs-CBs-ZEs(?), bt-CLOs-qz & Andesito & 15 & 1 & 37 & 41 & 94 & 53 & $\mathrm{E}$ & $\mathrm{T}$ & F/M & $\mathrm{F}$ & py+>cp, mg \pm rt-LCX, hm \\
\hline 3 & $\mathrm{~N}-3$ & $\mathrm{P}_{\mathrm{m}} / \mathrm{K}_{(\mathrm{c}) \mathrm{d}}$ & CLOs $\pm \mathrm{qz} \pm \mathrm{ARCs}, \mathrm{bt}$ & Andesito & 17 & 1 & 8 & 19 & 45 & 24 & $\mathrm{E}$ & $\mathrm{T}$ & $\mathrm{T}$ & $E$ & py $>\mathrm{cp}^{=}, \pm \mathrm{mg}$ \\
\hline 3 & M-5 & $\mathrm{P}_{\mathrm{m}} / \mathrm{K}_{(\mathrm{c}) \mathrm{d}}$ & ser,CLOs-ep-CBs, qz \pm bt, FPKs & Andesito & 11 & 4 & 32 & 35 & 82 & 44 & $\mathrm{~T} / \mathrm{E}$ & $\mathrm{T}$ & $\mathrm{M}$ & $\mathrm{M} / \mathrm{F}$ & $\mathrm{py}^{+} \pm \mathrm{mg}$ \\
\hline 1 & B-1 & $\mathrm{P}_{\mathrm{d}-\mathrm{m}} / \mathrm{K}_{(\mathrm{c}) \mathrm{i}}$ & qz-CLOs-ser-ARCs, ser- CLOs, \pm CBs, bt & Andesito & 2 & 2 & 11 & 14 & 29 & 14 & $\mathrm{~T}$ & $\mathrm{~T}$ & $\mathrm{~T} / \mathrm{E}$ & $\mathrm{E}$ & mg+, py, cp \pm mg-hm, rt. \\
\hline 3 & V-3 & $\mathrm{P}_{\mathrm{m}-\mathrm{f}} / \mathrm{K}_{(\mathrm{c}) \mathrm{d}}$ & CLOs-ep-ZEs(?) \pm qz, bt, & Andesito & 2 & 1 & 24 & 18 & 45 & 27 & $\mathrm{~T}$ & $\mathrm{~T}$ & $\mathrm{E} / \mathrm{M}$ & $E$ & py>cp- mg \\
\hline 3 & P-3 & $\mathrm{P}_{\mathrm{d}} / \mathrm{K}_{\mathrm{i}(?)}$ & CBs-CLOs-ser \pm qz-FPKs (?) & Pórfiro-I (micro quartzo monzonito - micro monzogranito) & 8 & & 10 & 14 & 32 & 18 & $\mathrm{~T}$ & - & $\mathrm{T} / \mathrm{E}$ & E & $\mathrm{py}>\mathrm{cp} \pm \mathrm{rt} \pm \mathrm{mg}$ \\
\hline 2 & $\mathrm{H}-2$ & $\mathrm{P}_{\mathrm{m}-\mathrm{i}} / \mathrm{K}_{(\mathrm{c}) \mathrm{i}}$ & CLOs-CBs \pm qz, ser, bt-qz. & Andesito & 2 & & 3 & 3 & 8 & 5 & $\mathrm{~T}$ & - & $\mathrm{T}$ & $\mathrm{T}$ & $\mathrm{mg}^{+}, \mathrm{hm} \pm \mathrm{py}, \mathrm{cp}, \mathrm{cv}$, bor, arsenopirita(?) \\
\hline 1 & E-1 & $\mathrm{P}_{\mathrm{m}} / \mathrm{K}_{\mathrm{i}}$ & $\mathrm{qz}, \mathrm{CLOs} \pm \mathrm{CBs} \pm \mathrm{ep} \pm \mathrm{ARCs}, \mathrm{FPKs}, \mathrm{bt}$ & Andesito & 3 & & 6 & 8 & 17 & 9 & $\mathrm{~T}$ & - & $\mathrm{T}$ & $\mathrm{T}$ & $\mathrm{cp} \geq \mathrm{py}, \mathrm{mg}, \mathrm{mb}$ \\
\hline 3 & $\mathrm{~T}-2$ & $\mathrm{P}_{\mathrm{m}} / \mathrm{K}_{\mathrm{i}}$ & qz, CLOs-mus-ser-CBs-ep, qz-FPKs & Micro-granodiorito porfirítico & 3 & & 2 & 4 & 9 & 4 & $\mathrm{~T}$ & - & $\mathrm{T}$ & $\mathrm{T}$ & $\mathrm{cp}>\mathrm{py}, \mathrm{mb} \pm \mathrm{rt}$ \\
\hline 3 & S-1 & $\mathrm{P}_{\mathrm{d}} / \mathrm{K}_{\mathrm{i}}$ & ser-qz-CLOs-CBs, qz-FPKs & Pórfiro I (micro quartzo monzonito - micro monzogranito) & 3 & & 3 & 6 & 12 & 6 & $\mathrm{~T}$ & - & $\mathrm{T}$ & $\mathrm{T}$ & $\mathrm{cp}>\mathrm{py}^{-} \pm \mathrm{rt}-\mathrm{LCX}, \mathrm{mb}$ \\
\hline 3 & $\mathrm{~K}-3$ & $\mathbf{P}_{\mathbf{m}} / \mathrm{K}_{\mathrm{m}-\mathrm{d}(?)}$ & CBs-CLOs $\pm \mathrm{qz} \pm$ ser \pm ARCs, FPKs(?) & Andesito-II & 4 & & 2 & 6 & 12 & 6 & $\mathrm{~T}$ & - & $\mathrm{T}$ & $\mathrm{T}$ & py $>$ cp, mg, rt-LCX \pm hm \\
\hline 3 & $\mathrm{~V}-2$ & $\mathrm{P}_{\mathrm{d}-\mathrm{m}} / \mathrm{K}_{(\mathrm{c}) \mathrm{i}}$ & qz-CBs-CLOs \pm ep \pm bt & Andesito & 7 & & & 7 & 14 & 7 & $\mathrm{~T}$ & - & - & $\mathrm{T}$ & py > cp $=m g$ \\
\hline 3 & $\mathrm{R}-3$ & $\mathrm{P}_{\mathrm{d}} / \mathrm{K}_{\mathrm{i}}$ & CLOs-CBs \pm ep \pm ser \pm qz, FPKs-qz & Micro-tonalito porfirítico & 1 & & & 1 & 2 & 1 & $\mathrm{~T}$ & - & - & $\mathrm{T}$ & $\mathrm{cp}^{+}>\mathrm{py}=\mathrm{mb}, \mathrm{rt}-\mathrm{LCX}$. \\
\hline 3 & $\mathrm{~T}-3$ & $\mathrm{P}_{\mathrm{d}} / \mathrm{K}_{\mathrm{i}(?)}$ & CLOs-ep \pm ser \pm qz \pm FPKs (?) & Micro-granodiorito porfirítico & 2 & 1 & & 2 & 5 & 2 & $\mathrm{~T}$ & $\mathrm{~T}$ & - & $\mathrm{T}$ & $\mathrm{cp} \geq \mathrm{py}, \mathrm{mg} \pm \mathrm{rt}-\mathrm{LCX} \pm \mathrm{hm} \pm \mathrm{mb} \pm$ bor $=$ \\
\hline 1 & G-1 & $\mathrm{P}_{\mathrm{f}} / \mathrm{K}_{(\mathrm{cod}}$ & CLOs-ep, bt & Andesito & & & 1 & 1 & 2 & 1 & - & - & $\mathrm{T}$ & $\mathrm{T}$ & mg, hm \\
\hline 1 & G-2 & $\mathrm{P}_{\mathrm{f}} / \mathrm{K}_{(\mathrm{c}) \mathrm{i}}$ & qz-CLOs-ep \pm ARCs, bt & Andesito & & & 4 & 2 & 6 & 4 & - & - & $\mathrm{T}$ & $\mathrm{T}$ & $\mathrm{mg}, \mathrm{py}^{\prime}, \pm \mathrm{cp}=$ \\
\hline 3 & $\mathrm{~S}-3$ & $\mathrm{P}_{\mathrm{d}} / \mathrm{K}_{\mathrm{i}(?)}$ & qz-CLOs-ep, FPKs-qz & Micro-granodiorito porfirítico & & & & & & & - & - & - & \begin{tabular}{|l|}
- \\
\end{tabular} & $\mathrm{cp}^{+}>\mathrm{py}^{-} \cong \mathrm{mg}^{-}$ \\
\hline 3 & $\mathrm{R}-4$ & silf, $P_{d} / K_{i}$ & qz, CLOs \pm ep, FPKs, & Andesito & & & & & & & - & - & - & \begin{tabular}{|c|}
- \\
\end{tabular} & rt-LCX, mg, cp- > py, hm, bor, cv \\
\hline 3 & P-4 & $\mathrm{P}_{\mathrm{d}} / \mathrm{K}_{\mathrm{i}(?)}$ & CBs-ser \pm CLOs \pm mus $=$, qz-FPKs(?) & Pórfiro-I (micro quartzo monzonito - micro monzogranito) & & & & & & & - & - & - & - & $\mathrm{cp}^{+}>$py, rt-LCX \\
\hline 3 & $\mathrm{Q}-2$ & $\mathrm{P}_{d} / \mathrm{K}_{\mathrm{i}}$ & ser-CBs-CLOs-CBs, qz-FPKs & Pórfiro-I (micro monzonito - micro monzogranito) & & & & & & & - & - & - & - & $\mathrm{cp}^{++}>\mathrm{py}-, \mathrm{rt}, \mathrm{mb}$ \\
\hline 3 & $\mathrm{P}-2$ & $\mathrm{~K}_{\mathrm{i}}-\mathrm{P}_{\mathrm{d}-\mathrm{i}} / \mathrm{silf}-\mathrm{F}_{\mathrm{i}(?)}$ & FPKs \pm qz, qz, CLOs-CBs-ep & Pórfiro-II micro tonalito - micro leucoquartzo diorito) & & & & & & & - & - & - & - & $\mathrm{cp}^{+}>\mathrm{py}^{-} \pm \mathrm{rt} \pm$ bor \\
\hline 3 & R-1 & $\mathrm{K}_{\mathrm{i}}-\mathrm{P}_{\mathrm{i}} /$ silf $_{(?)}$ & FPKs, ser \pm CBs \pm CLOs, qz & Pórfiro I (micro quartzo monzonito - micro monzogranito) & & & & & & & - & - & - & - & cp, py, mb \pm rt-LCX, \\
\hline
\end{tabular}




\begin{tabular}{|c|c|c|c|c|c|c|c|c|c|c|c|c|c|c|c|}
\hline \multirow{2}{*}{ Perfil } & \multirow{2}{*}{ Codigo } & \multirow{2}{*}{ Alteração } & \multirow{2}{*}{ Mineralogia } & \multirow{2}{*}{ Tipo de rocha } & \multicolumn{4}{|c|}{ Ocorrência } & \multirow{2}{*}{$\begin{array}{l}\text { Ocorrência } \\
\text { Total }\end{array}$} & \multirow{2}{*}{$\begin{array}{c}N^{\circ} \text { de } \\
\text { inclusões }\end{array}$} & \multicolumn{4}{|c|}{ Categorias } & \multirow{2}{*}{ Outros Minerais } \\
\hline & & & & & mck & cb & po & ср & & & mck & cb & po & $\mathbf{~ c p}$ & \\
\hline 2 & $\mathrm{H}-4$ & silf - $P_{(C B s) ~} m$ & qz, CBs-ser-qz \pm mus \pm bt $^{=}$ & Pórfiro-II (micro tonalito - micro leucoquartzo diorito) & 9 & & 6 & 10 & 25 & 14 & $\mathrm{~T}$ & - & $\mathrm{T}$ & $\mathrm{T} / \mathrm{E}$ & $\mathrm{py}>\mathrm{cp} \pm \mathrm{rt}, \mathrm{hm}^{-}$, bor $^{=}$ \\
\hline 1 & $\mathrm{C}-2$ & $P_{t-m}$ & CLOs-CBs-ARCs, qz-ZEs(?)-CLOs, \pm ep \pm bt ${ }^{=}$ & Andesito & 12 & & 6 & 16 & 34 & 17 & $\mathrm{~T} / \mathrm{E}$ & - & $\mathrm{T}$ & $\mathrm{E}$ & $\mathrm{py} \cong \mathrm{cp}, \mathrm{mb}, \mathrm{mg}, \mathrm{rt}-\mathrm{LCX}$ \\
\hline 1 & C-1 & $\mathrm{P}_{(\mathrm{CBS})}$ & qz-CBs-CLOs \pm ARCs, qz-ser, \pm FPKs & Hidrotermalito CBs-ser-cz-CLOs (possivel: Andesito) & 1 & & 2 & 3 & 6 & 3 & $\mathrm{~T}$ & - & $\mathrm{T}$ & $\mathrm{T}$ & $\mathrm{cp}^{-} \cong \mathrm{py}^{-}, \mathrm{rt}, \mathrm{mb}^{+}$ \\
\hline 2 & $\mathrm{H}-3$ & $P_{(C B s) m-d}$ & CBs-ser土 CLOs & Micro-brecha & 2 & & & 2 & 4 & 2 & $\mathrm{~T}$ & - & - & $\mathrm{T}$ & py > cp, ef(?), hm(?) \\
\hline 1 & G-3 & $P_{\mathrm{f}}$ & ep-CBs-CLOs \pm bt \pm anh $\pm \mathrm{qz}$ & Andesito & & & 2 & 1 & 3 & 2 & - & - & $\mathrm{T}$ & $\mathrm{T}$ & $\mathrm{mg}^{+}, \mathrm{py}>\mathrm{cp}^{-}, \mathrm{hm}^{=}$ \\
\hline 1 & A-1 & $P_{t-m}$ & CLOs-CBs-qz \pm ep \pm bt, ser, ARCs & Hidrotermalito ARCs-ser-CBs-CLOs (possivel: Andesito) & & & & & & & - & - & - & - & $\mathrm{py} \cong \mathrm{cp}, \mathrm{mg}$ \\
\hline 1 & $\mathrm{D}-2$ & $P_{t-m}$ & ARCs-CLOs-ser-CBs-qz \pm ep \pm bt & Hidrotermalito ARCs-ser-qz-CLOs (possivel: Andesito) & & & & & & & - & - & - & - & $\mathrm{cp}>\mathrm{py}, \mathrm{mg}=$ \\
\hline 2 & $\mathrm{I}-2$ & $P_{(C B s) d-m}$ & ser-CBs \pm mus \pm ARCs & Qz latito & & & & & & & - & - & - & - & py > cp, rt-LCX, bor ${ }^{\prime}(?)$ \\
\hline 1 & $\mathrm{~A}-2$ & $P_{(C B s)}$ & CBs-ser \pm CLOs \pm ep & Qz latito & & & & & & & - & - & - & - & rt, py \\
\hline 1 & $\mathrm{~A}-3$ & $P_{(C B s)}$ & qz, CBs-CLOs-ser \pm ep & Qz latito & & & & & & & - & - & - & - & py, rt-LCX \\
\hline 3 & $\mathrm{R}-2$ & $\mathrm{P}_{\mathrm{d}}$ & CLOs-CBs-ARCs \pm ер & Qz latito & & & & & & & - & - & - & - & LCX, mg-hm, cp, py, ef \\
\hline 3 & U-3 & $K_{i(?)}=P_{i} / F_{i}$ & qz-ser-mus \pm rt, CBs-ep \pm CLOs, \pm FPKs & Pórfiro-II (micro tonalito - micro leucoquartzo diorito) & 11 & 2 & 8 & 18 & 39 & 20 & $\mathrm{~T} / \mathrm{E}$ & $\mathrm{T}$ & $\mathrm{T}$ & $\mathrm{E}$ & py > cp, mb, rt-LCX \\
\hline 1 & F-1 & $\mathrm{K}_{\mathrm{i}(?)=}=\mathbf{P}_{\mathrm{i}} / \mathbf{F}_{\mathrm{i}}$ & FPKs-qz, ser, CLOs \pm CBs \pm ep & Hidrotermalito de FPKs(?), ser, qz, CLOs-CBs-ep & 12 & 10 & 30 & 40 & 92 & 43 & $\mathrm{~T} / \mathrm{E}$ & $\mathrm{T}$ & M & $\mathrm{F}$ & py $>$ cp', rt-LCX \\
\hline 3 & $\mathrm{~T}-1$ & $P_{m}-F_{?(\text { (sil) }}$ & qz-ser, CBs-CLOs-ARCs \pm ep & Pórfiro alt. a qz-ARCs-ser-CBs \pm rt (possivel: pórfiro-II) & 6 & 1 & 3 & 6 & 16 & 6 & $\mathrm{~T}$ & $\mathrm{~T}$ & $\mathrm{~T}$ & $\mathrm{~T}$ & $\mathrm{cp} \cong \mathrm{py}, \mathrm{rt}-\mathrm{LCX}, \mathrm{mb}$ \\
\hline 1 & B-2 & $\mathrm{P}_{\mathrm{d}} / \mathrm{F}_{?}$ (silf $)$ & $\mathrm{qz} \pm \mathrm{ser}, \mathrm{CBs}-\mathrm{CLO} \pm \mathrm{ep} \pm \mathrm{anh} \pm \mathrm{bt}, \mathrm{ZEs}(?)$ & Andesito & 2 & 1 & 5 & 6 & 14 & 7 & $\mathrm{~T}$ & $\mathrm{~T}$ & $\mathrm{~T}$ & $\mathrm{~T}$ & $\mathrm{py}>\mathrm{cp}, \mathrm{mg}, \mathrm{rt}$ \\
\hline 2 & $\mathrm{~J}-2$ & $\mathrm{P}_{\mathrm{f}-\mathrm{m}} / \mathrm{F}_{(?)}$ & qz-ARCs-ser-CLOs-CBs & $\begin{array}{l}\text { Hidrotermalito de ser-cz-py (possivel: Micro granodiorito } \\
\text { porfirítico-micro tonalito porfiritico()) }\end{array}$ & 4 & 3 & 14 & 15 & 36 & 17 & $\mathrm{~T}$ & $\mathrm{~T}$ & E & $\mathrm{E}$ & $\mathrm{mg}^{+}, \mathrm{LCX}, \mathrm{py}>\mathrm{cp}{ }^{-}, \mathrm{hm}^{=}$ \\
\hline 2 & $\mathrm{I}-3$ & $\mathrm{P}_{(\mathrm{CBs})} / \mathrm{Ser}_{\mathrm{m}-\mathrm{d}}$ & ser-CBs-CLOs $\pm \mathrm{qz} \pm$ ep \pm mus & Qz latito & & 1 & 3 & 1 & 5 & 3 & - & $\mathrm{T}$ & $\mathrm{T}$ & $\mathrm{T}$ & $\mathrm{cp}>\mathrm{py}, \mathrm{rt}-\mathrm{LCX} \pm \mathrm{ef} \pm \mathrm{gl} \pm \mathrm{mg} \pm \mathrm{hm}$ \\
\hline 3 & $\mathrm{O}-2$ & $\mathrm{P}_{\mathrm{m}}-\mathrm{F}_{\mathrm{d}}$ & $\mathrm{qz} \pm \mathrm{ser}, \mathrm{CBs}-\mathrm{CLO} \pm \mathrm{ARCs}$ & Pórfiro-II (micro tonalito - micro leucoquartzo diorito) & 4 & & 2 & 6 & 12 & 6 & $\mathrm{~T}$ & - & $\mathrm{T}$ & $\mathrm{T}$ & cp > py, mb, hm \\
\hline 3 & S-2 & $\mathrm{P}_{\mathrm{d}-\mathrm{F}_{?(\text { (il })}}$ & $\mathrm{qz}^{+}$, CLOs-ep-CBs-ser \pm FPKs & Porfido silicificado (possivel: Pórfiro-II) & & & & & & & - & - & - & - & cp > py, rt-LCX, mg-hm \\
\hline 2 & $\mathrm{~J}-4$ & $F_{m-f} / P_{d}$ & ser, qz, ARCs-CLOs \pm CBs \pm ep & $\begin{array}{l}\text { Pórfiro alterado a ARCs-ser-qz, CLOS-CBs (possivel: Micro } \\
\text { granodiorito porfiritico-micro tonalito porfiritico(?)) }\end{array}$ & 4 & 12 & 42 & 44 & 102 & 47 & $\mathrm{~T}$ & $\mathrm{~T} / \mathrm{E}$ & $\mathrm{F}$ & $\mathrm{F}$ & py > cp, mg, rt-LCX \\
\hline 3 & U-1 & $\mathrm{F}_{\mathrm{f}}=\mathrm{P}_{\mathrm{d}}$ & ser-qz, CLOs-CBs \pm mus \pm ARCs & Pórfiro alt. a ser-qz-CLOs-CBs-ARCs (possivel: pórfiro-II) & 13 & 3 & 10 & 23 & 49 & 23 & $\mathrm{E} / \mathrm{T}$ & $\mathrm{T}$ & $\mathrm{T} / \mathrm{E}$ & $\mathrm{E} / \mathrm{M}$ & cp>py, rt-LCX \\
\hline 3 & $\mathrm{~N}-2$ & $\mathrm{~F}_{\mathrm{m}}=\mathrm{P}_{\mathrm{d}-\mathrm{m}}$ & ser-qz, CBs-CLOs \pm ARCs & Hidrotermalito ser- CBs-qz- CLOs (possivel: Riolito?) & 13 & 2 & 18 & 30 & 63 & 30 & $\mathrm{E} / \mathrm{T}$ & $\mathrm{T}$ & E & $\mathrm{M}$ & $\mathrm{py}^{+}>\mathrm{cp}, \mathrm{rt}-\mathrm{LCX} \pm \mathrm{mg}(?)$ \\
\hline 2 & $\mathrm{~J}-3$ & $\mathrm{~F}_{\mathrm{d}} / \mathrm{P}_{\mathrm{i}}$ & ser, qz, CBs-ARCs-CLOs \pm ep & Micro granodiorito porfiritico- Micro tonalito porfiritico(?) & 1 & 5 & 11 & 15 & 32 & 15 & $\mathrm{~T}$ & $\mathrm{~T}$ & $\mathrm{~T} / \mathrm{E}$ & E & py, cp, rt, mg, bor $=$ \\
\hline 2 & $\mathrm{I}-4$ & Ser / $P_{(C B s) d-m}$ & ser, CBs-CLOs \pm ep & Qz latito & 1 & 1 & 1 & 2 & 5 & 2 & $\mathrm{~T}$ & $\mathrm{~T}$ & $\mathrm{~T}$ & $\mathrm{~T}$ & py, cp, rt-LCX, mg-hm, ef(?) \\
\hline 3 & M-4 & Silf $_{\mathrm{m}(\mathrm{FP} ?)}=\mathrm{P}_{\mathrm{d}}$ & qz, CLOs-ser-CBs-ARCs \pm ep & Andesito & 4 & & 20 & 21 & 45 & 23 & $\mathrm{~T}$ & - & $\mathrm{E}$ & $\mathrm{E}$ & py+, rt-LCX, cp \\
\hline 3 & $\mathrm{U}-2$ & $\mathrm{~F}_{\mathrm{dr}} \mathrm{P}_{\mathrm{d} /} /$ silf & $\mathrm{qz}, \mathrm{ser}, \mathrm{CBs} \pm \mathrm{CLOs}$ & Pórfiro-II (micro leucoquartzo diorito - micro tonalito) & 9 & & 6 & 13 & 28 & 15 & $\mathrm{~T}$ & - & $\mathrm{T}$ & $\mathrm{E} / \mathrm{T}$ & $\mathrm{cp} \geq \mathrm{py}, \mathrm{rt}-\mathrm{LCX}, \mathrm{mb}$ \\
\hline 2 & $\mathrm{I}-1$ & Ser-P $(\mathrm{CBs}) \mathrm{m}-\mathrm{d}$ & ser, CBs-CLOs \pm ARCs \pm ep & Qz latito & & & & & & & - & - & - & - & $\mathrm{py} \cong \mathrm{cp} \pm$ bor $\pm \mathrm{rt}-\mathrm{LCX} \pm \mathrm{hm} \pm \mathrm{mg} \pm \mathrm{cv}=\mathrm{dg}(?)$ \\
\hline 3 & P-1 & $\mathrm{F}_{\mathrm{m}}-\mathrm{P}_{\mathrm{i}}$ & qz-ser \pm CLOs-CBs \pm ep & Pórfiro alt. a qz-ser (possivel: pórfiro-II) & & & & & & & - & - & - & - & cp > py, rt-LCX, mg, mb \\
\hline 1 & D-1 & $\mathrm{F}_{\mathrm{f}} / \mathrm{Pi}_{(\mathrm{CBS})}$ & qz-ser-CBs \pm ARCs & Pórfiro alt. a ser-qz-py (possivel: pórfiro-II) & & & & & & & - & - & - & - & $\mathrm{py}>\mathrm{cp}, \mathrm{mb}, \mathrm{LCX} \pm \mathrm{bor} \pm \mathrm{cv} \pm \mathrm{hm}(?)$ \\
\hline 2 & $\mathrm{~J}-1$ & $\mathrm{~F}_{\mathrm{f}}$ & ser-qz-ARCs \pm CLOs & $\begin{array}{l}\text { Hidrotermalito de ser-cz-py (possivel: Micro granodiorito } \\
\text { porfirítico-micro tonalito porfiritico(?)) }\end{array}$ & 11 & 5 & 12 & 21 & 49 & 23 & $\mathrm{~T} / \mathrm{E}$ & $\mathrm{T}$ & $\mathrm{T} / \mathrm{E}$ & E & $\mathrm{py}^{-} \geq \mathrm{cp}, \mathrm{rt}-\mathrm{LCX} \pm \mathrm{cv}=$ \\
\hline
\end{tabular}




\begin{tabular}{|c|c|c|c|c|c|c|c|c|c|c|c|c|c|c|c|}
\hline \multirow{2}{*}{ Perfil } & \multirow{2}{*}{ Codigo } & \multirow{2}{*}{ Alteração } & \multirow{2}{*}{ Mineralogia } & \multirow{2}{*}{ Tipo de rocha } & \multicolumn{4}{|c|}{ Ocorrência } & \multirow{2}{*}{$\begin{array}{c}\text { Ocorrência } \\
\text { Total }\end{array}$} & \multirow{2}{*}{$\begin{array}{c}\mathbf{N}^{\circ} \text { de } \\
\text { inclusões }\end{array}$} & \multicolumn{4}{|c|}{ Categorias } & \multirow{2}{*}{ Outros Minerais } \\
\hline & & & & & mck & cb & po & ср & & & mck & cb & po & сp & \\
\hline 3 & $0-1$ & $\mathrm{~F}_{\mathrm{f}-\mathrm{m}}$ & ser-qz \pm ARCs & Pórfido alterado a ser-qz- ARCs (possivel: Riolito) & 34 & 4 & 27 & 61 & 126 & 63 & $\mathrm{M}$ & $\mathrm{T}$ & $\mathrm{M}$ & $\mathrm{A}$ & $\mathrm{py} \geq \mathrm{cp}$ \\
\hline 3 & Q-1 & $\mathrm{F}_{\mathrm{f}}$ & ser-qz, CBs & Hidrotermalito de ser-cz-CBs-py (possivel: Riolito) & 10 & 5 & 17 & 27 & 59 & 29 & $\mathrm{~T} / \mathrm{E}$ & $\mathrm{T}$ & $\mathrm{E}$ & м & $\mathrm{py} \cong \mathrm{cp} \pm$ bor- $\mathrm{mb}$, ef \\
\hline 3 & L-3 & $F_{f}$ & ser-qz \pm ARCs & Riolito & 5 & & 1 & 6 & 12 & 6 & $\mathrm{~T}$ & - & $\mathrm{T}$ & $\mathrm{T}$ & py $>$ cp, $\pm \mathrm{cv} \pm$ bor $^{=}$ \\
\hline 3 & $\mathrm{~L}-2$ & $F_{\mathrm{f}}$ & ser-qz- \pm ARCs & Riolito & 2 & & & 2 & 4 & 2 & $\mathrm{~T}$ & - & - & $\mathrm{T}$ & py $>$ cp, \pm bor $=$, cc $=$ \\
\hline 3 & $\mathrm{~K}-2$ & $\mathrm{~F}_{\mathrm{d}-\mathrm{m}}$ & ser-qz- \pm ARCs \pm mus & Riolito & & & 3 & & 3 & 3 & - & - & $\mathrm{T}$ & - & $\mathrm{py}^{+}>\mathrm{cp}$, CGRs(?), bor, cv, gl, ef. \\
\hline 3 & L-1 & $\mathrm{F}_{\mathrm{f}-\mathrm{m}}$ & ser-qz \pm ARCs & Riolito & 1 & & & 1 & 2 & 1 & $\mathrm{~T}$ & - & - & $\mathrm{T}$ & py > cp=, \\
\hline 3 & M-3 & $F_{f}$ & ser-ARCs-qz & Riolito & & & 1 & 1 & 2 & 1 & - & - & $\mathrm{T}$ & $\mathrm{T}$ & LCX, py > cp" cv $^{=}$, bor $^{=}$ \\
\hline 3 & $\mathrm{~N}-1$ & $\mathrm{~F}_{\mathrm{f}-\mathrm{m}}$ & ser-qz & Riolito & 1 & & 1 & 2 & 4 & 2 & $\mathrm{~T}$ & - & $\mathrm{T}$ & $\mathrm{T}$ & $\mathrm{py}^{+}>\mathrm{cp}=, \mathrm{rt}-\mathrm{LCX}, \pm \mathrm{cv}, \mathrm{cc}$, bor, CGRs(?) \\
\hline 3 & $\mathrm{~K}-1$ & $F_{f}$ & ser-qz \pm ARCs & Pórfido alterado a ser-qz-py (possivel: Riolito) & 2 & & 1 & 3 & 6 & 3 & $\mathrm{~T}$ & - & $\mathrm{T}$ & $\mathrm{T}$ & $\mathrm{py}^{+}$, rt-LCX, bor, cv, CGRs(?) arsenopirita(?) \\
\hline 3 & $\mathrm{M}-2$ & $F_{f}$ & qz-ser \pm ARCs & Riolito & & & & & & & - & - & - & - & py > cp, rt-LCX, bor ${ }^{\prime}, \mathrm{cv}^{\overline{ }}, \mathrm{cc}^{ }$ \\
\hline 3 & M-1 & $F_{f}$ & ser-qz-ARCs & Hidrotermalito de ser-cz \pm ARCs (possivel: Riolito) & & & & & & & - & - & - & - & 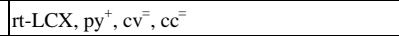 \\
\hline & & & & Soma total & 302 & 83 & 521 & 695 & 1601 & 824 & & & & & \\
\hline
\end{tabular}


ANEXO 6

PERFIS INDICANDO OS TIPOS DE ALTERAÇÃO HIDROTERMAL

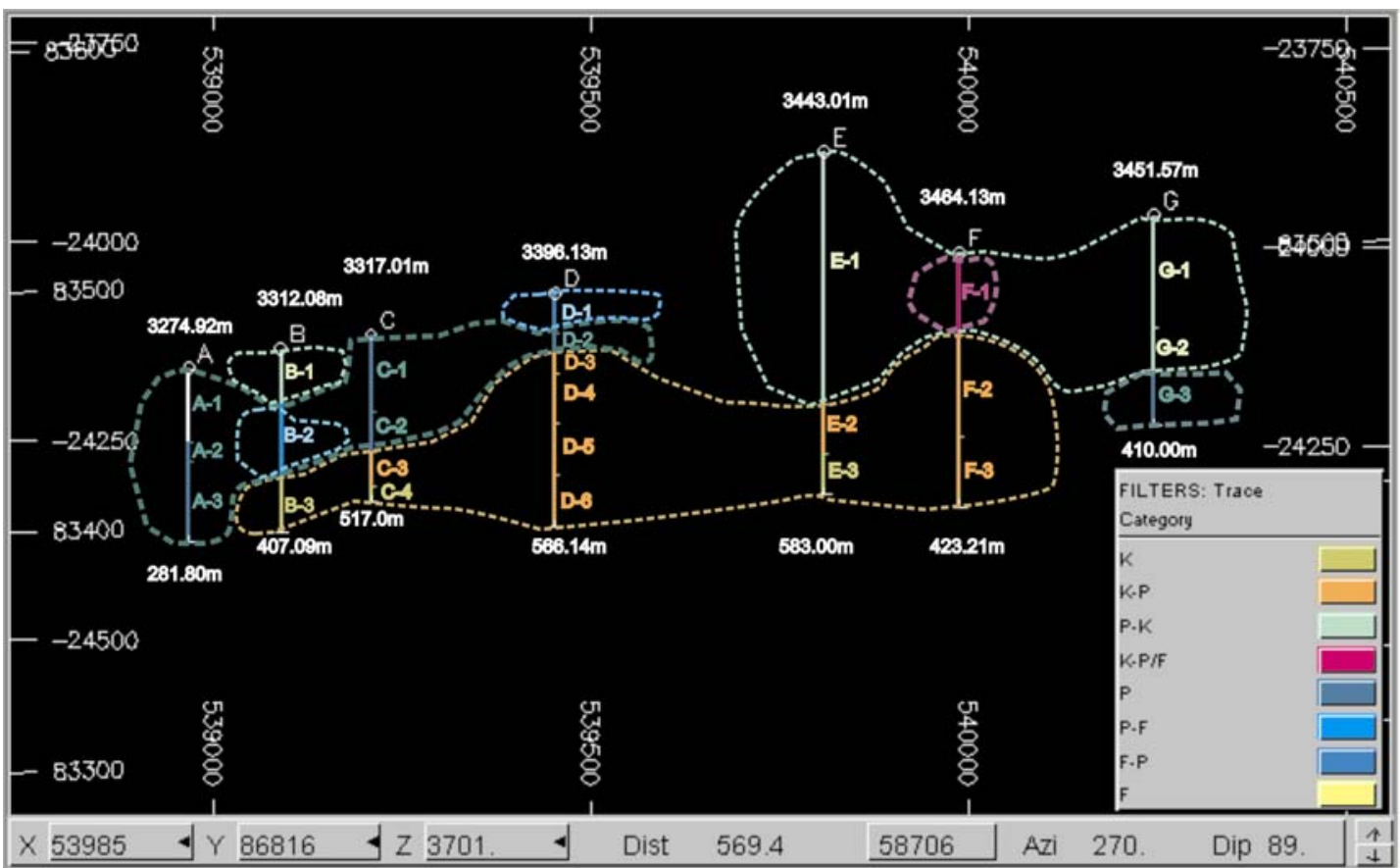

Anexo 6.1: Perfil 1 com seus respectivos furos de sondagem $A-G$, indicando os tipos de alterações hidrotermais presentes na jazida de Cuajone. Cota e profundidade na parte superior e inferior de cada furo de sondagem. Ver abreviaturas dos tipos de rochas e alterações no Anexo 1.

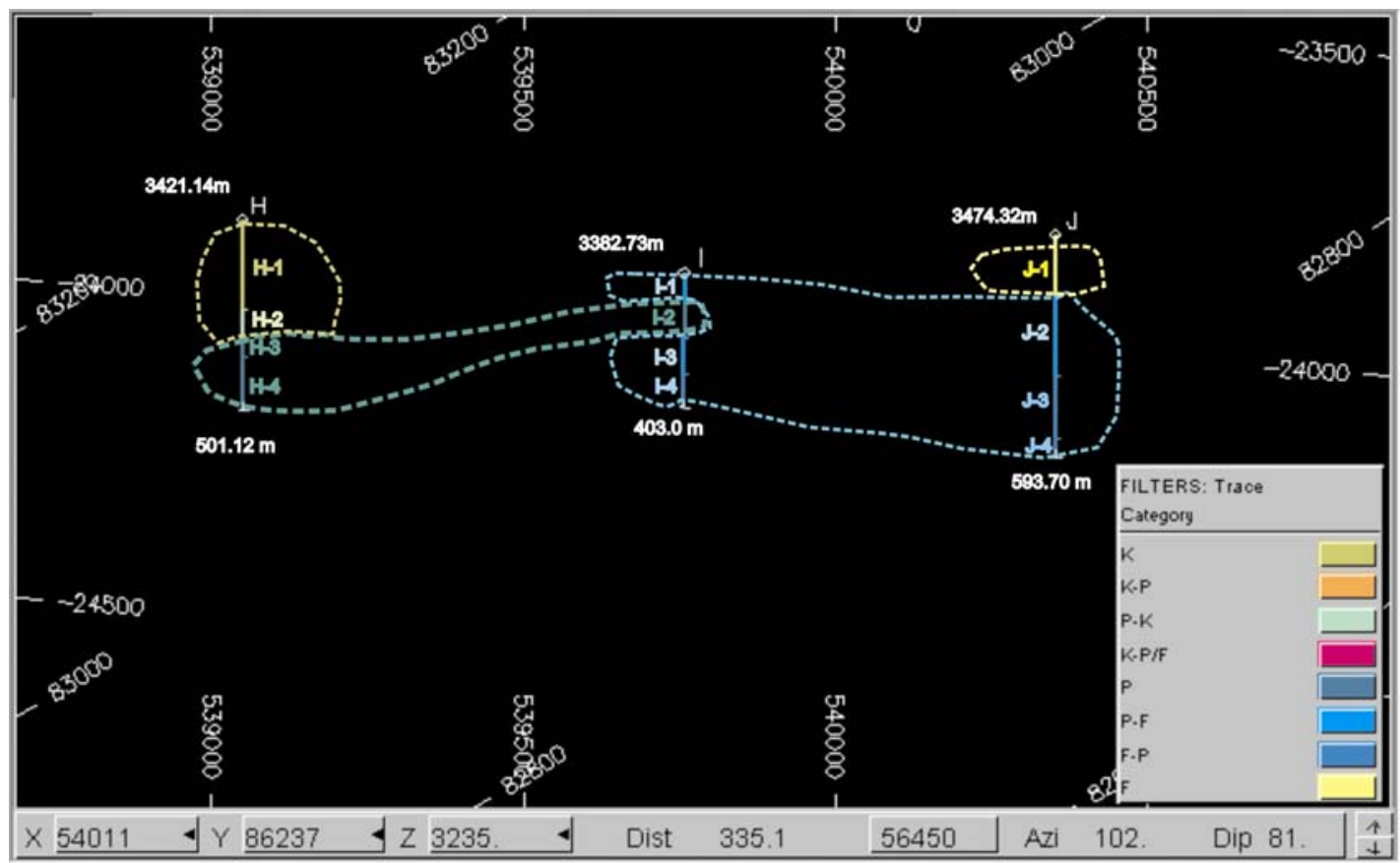

Anexo 6.2: Perfil 2 com seus respectivos furos de sondagem H, I, J indicando os tipos de alterações hidrotermais presentes na jazida de Cuajone. Cota e profundidade na parte superior e inferior de cada furo de sondagem. Ver abreviaturas dos tipos de rochas e alterações no Anexo 1. 


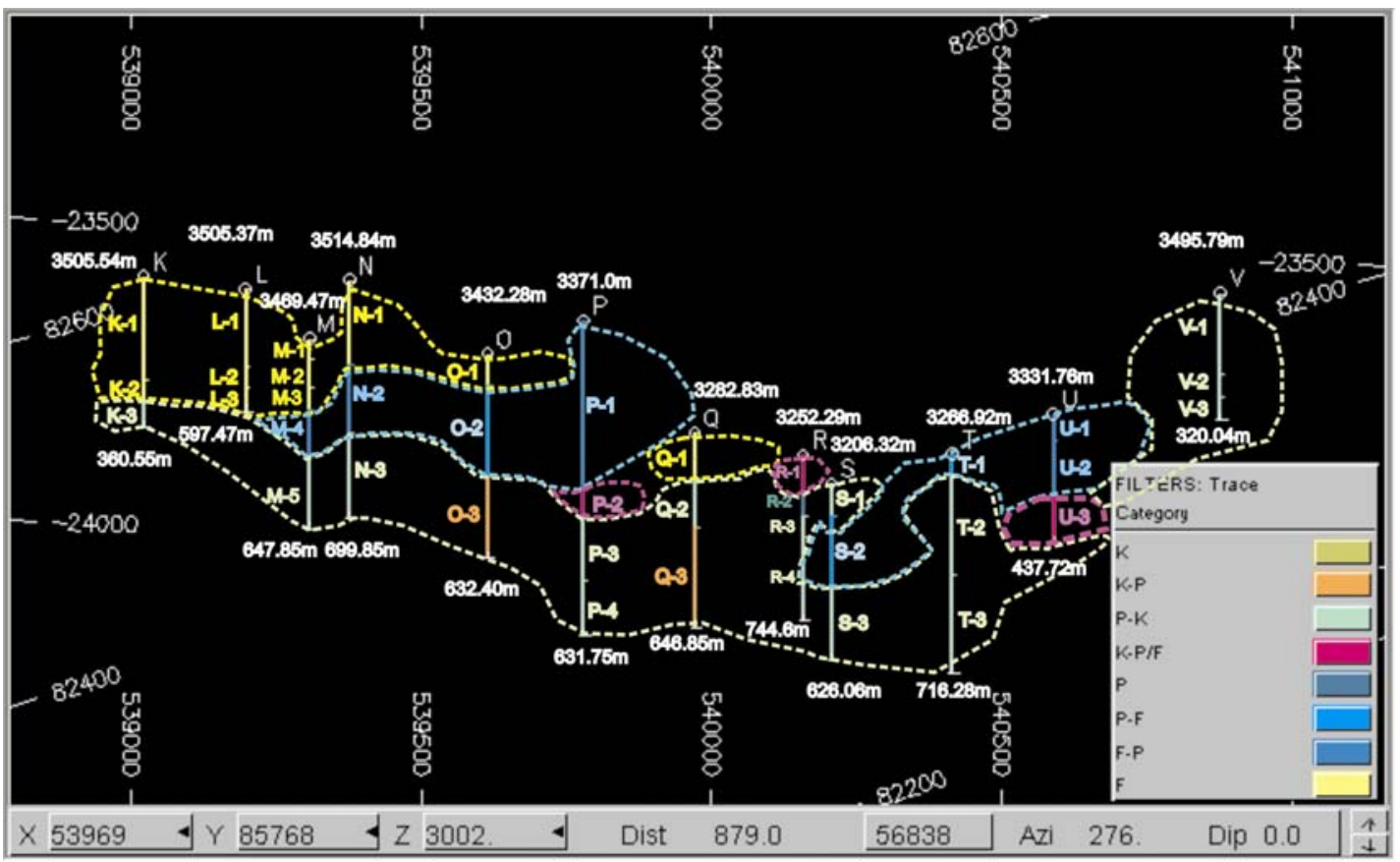

Anexo 6.3: Perfil 3 com seus respectivos furos de sondagem $\mathrm{K}-\mathrm{V}$, indicando os tipos de alterações hidrotermais presentes na jazida de Cuajone. Cota e profundidade na parte superior e inferior de cada furo de sondagem. Ver abreviaturas dos tipos de rochas e alterações no Anexo 1. 
ANEXO 7

TIPOS DE INTERCRESCIMENTOS NAS DIFERENTES ZONAS DE ALTERAÇÃO HIDROTERMAL

\begin{tabular}{|c|c|c|c|}
\hline \multicolumn{2}{|c|}{} & $\begin{array}{c}\text { Soma total } \\
\text { na alteração } \\
\text { Potássica } \\
(\mathrm{K})\end{array}$ & $\%$ \\
\hline 1 & $\mathrm{cp} / \mathrm{mck}: 1 \mathrm{e}$ & 1 & 11.1 \\
\hline 2 & $\mathrm{cp} / \mathrm{mck}: 4 \mathrm{f}$ & 1 & 11.1 \\
\hline 3 & $\mathrm{cp} / \mathrm{po}: 1 \mathrm{~b}$ & 2 & 22.2 \\
\hline 4 & $\mathrm{cp} / \mathrm{po}: 4 \mathrm{f}$ & 1 & 11.1 \\
\hline 5 & $\mathrm{po} / \mathrm{cp}: 1 \mathrm{a}$ & 1 & 11.1 \\
\hline 6 & $\mathrm{py} / \mathrm{po}: 1 \mathrm{e}$ & 3 & 33.3 \\
\hline & & 9 & 100 \\
\hline
\end{tabular}

\begin{tabular}{|c|c|c|c|}
\hline \multicolumn{2}{|c|}{ Intercrescimentos } & \multirow[t]{2}{*}{$\begin{array}{c}\text { Soma total } \\
\text { na } \\
\text { alteração } \\
\text { Potássica- } \\
\text { Propílica } \\
\text { (K-P) } \\
10\end{array}$} & \multirow{2}{*}{$\begin{array}{c}\% \\
6.2 \\
\end{array}$} \\
\hline 1 & $\mathrm{cp} / \mathrm{mck}: 1 \mathrm{~b}$ & & \\
\hline 2 & cp/mck:1e & 4 & 2.5 \\
\hline 3 & cp/mck:3b & 2 & 1.2 \\
\hline 4 & $\mathrm{cp} / \mathrm{mck}: 4 \mathrm{f}$ & 15 & 9.3 \\
\hline 5 & $\mathrm{cp} / \mathrm{cb}: 1 \mathrm{a}$ & 2 & 1.2 \\
\hline 6 & $\mathrm{cb} / \mathrm{cp}: 1 \mathrm{~b}$ & 1 & 0.6 \\
\hline 7 & $\mathrm{cb} / \mathrm{cp}: 3 \mathrm{~b}$ & 1 & 0.6 \\
\hline 8 & cp/po:1a & 14 & 8.6 \\
\hline 9 & $\mathrm{cp} / \mathrm{po}: 1 \mathrm{~b}$ & 15 & 9.3 \\
\hline 10 & $\mathrm{cp} / \mathrm{po}: 1 \mathrm{e}$ & 2 & 1.2 \\
\hline 11 & $\mathrm{cp} / \mathrm{po}: 3 \mathrm{~b}$ & 1 & 0.6 \\
\hline 12 & $\mathrm{cp} / \mathrm{po}: 4 \mathrm{f}$ & 12 & 7.4 \\
\hline 13 & $\mathrm{po} / \mathrm{cp}: 1 \mathrm{a}$ & 6 & 3.7 \\
\hline 14 & $\mathrm{po} / \mathrm{cp}: 1 \mathrm{~b}$ & 5 & 3.1 \\
\hline 15 & $\mathrm{py} / \mathrm{po}: 1 \mathrm{e}$ & 50 & 30.9 \\
\hline 16 & cp/mck:1b,1e & 2 & 1.2 \\
\hline 17 & $\mathrm{cp} / \mathrm{cb}: 1 \mathrm{a}, 4 \mathrm{f}$ & 1 & 0.6 \\
\hline 18 & $\mathrm{cp} / \mathrm{po}: 1 \mathrm{a}, 1 \mathrm{e}$ & 1 & 0.6 \\
\hline 19 & $\mathrm{cp} / \mathrm{po}: 1 \mathrm{~b}, 3 \mathrm{a}$ & 1 & 0.6 \\
\hline 20 & (cp/po:4f)/cb:4f & 1 & 0.6 \\
\hline 21 & $(\mathrm{cp} / \mathrm{po}: 4 \mathrm{f}) / \mathrm{mck}: 4 \mathrm{f}$ & 1 & 0.6 \\
\hline 22 & $\mathrm{cp} /(\mathrm{cb} / \mathrm{mck}: 1 \mathrm{c}): 3 \mathrm{~d}$ & 1 & 0.6 \\
\hline 23 & $\mathrm{cp} /(\mathrm{po} / \mathrm{cb}: 3 \mathrm{a}): 1 \mathrm{~b}$ & 1 & 0.6 \\
\hline 24 & $(\mathrm{cp} / \mathrm{cb}: 1 \mathrm{a}) / \mathrm{mck}: 4 \mathrm{f}$ & 1 & 0.6 \\
\hline 25 & $(\mathrm{cp} / \mathrm{cb}: 3 \mathrm{a}) / \mathrm{mck}: 1 \mathrm{e}$ & 1 & 0.6 \\
\hline 26 & (cp/cb:4f)/mck:1e & 1 & 0.6 \\
\hline 27 & $(\mathrm{cp} / \mathrm{mck}: 1 \mathrm{~b}, 4 \mathrm{f}) / \mathrm{po}: 1 \mathrm{e}$ & 1 & 0.6 \\
\hline 28 & $(\mathrm{cp} / \mathrm{po}: 1 \mathrm{e}) / \mathrm{mck}: 1 \mathrm{~b}$ & 1 & 0.6 \\
\hline 29 & $(\mathrm{cp} / \mathrm{po}: 1 \mathrm{~b}) / \mathrm{mck}: 1 \mathrm{e}$ & 2 & 1.2 \\
\hline 30 & $(\mathrm{cp} / \mathrm{po}: 1 \mathrm{~b}) / \mathrm{cb}: 1 \mathrm{a}$ & 1 & 0.6 \\
\hline 31 & $(\mathrm{cp} / \mathrm{po}: 1 \mathrm{~b}) / \mathrm{cb}: 1 \mathrm{~b}$ & 1 & 0.6 \\
\hline 32 & $(\mathrm{cp} / \mathrm{po}: 1 \mathrm{~b}) / \mathrm{cb}: 3 \mathrm{a}$ & 2 & 1.2 \\
\hline 33 & {$[(\mathrm{cp} / \mathrm{po}: 1 \mathrm{~b}) / \mathrm{cb}: 1 \mathrm{a}] / \mathrm{mck}: 1 \mathrm{e}$} & 1 & 0.6 \\
\hline 34 & $\{[\mathrm{cp} /(\mathrm{po} / \mathrm{mck}: 1 \mathrm{a}): 1 \mathrm{~b}] / \mathrm{cb}: 1 \mathrm{a}\} / \mathrm{mck}: 1 \mathrm{e}$ & 1 & 0.6 \\
\hline & & 162 & 100 \\
\hline
\end{tabular}

7.1 e 7.2 - Intercrescimentos em hachurado são os mais importantes. 


\begin{tabular}{|c|c|c|c|}
\hline & Intercrescimentos & $\begin{array}{l}\text { Soma total na } \\
\text { alteração } \\
\text { Propílica - }\end{array}$ & $\%$ \\
\hline 1 & $\mathrm{cp} / \mathrm{mck}: 1 \mathrm{~b}$ & 20 & 8.9 \\
\hline 2 & $\mathrm{cp} / \mathrm{mck}: 1 \mathrm{c}$ & 2 & 0.9 \\
\hline 3 & $\mathrm{cp} / \mathrm{mck}: 1 \mathrm{~d}$ & 1 & 0.4 \\
\hline 4 & cp/mck:1e & 7 & 3.1 \\
\hline 5 & cp/mck:3a & 1 & 0.4 \\
\hline 6 & $\mathrm{cp} / \mathrm{mck}: 3 \mathrm{~b}$ & 5 & 2.2 \\
\hline 7 & $\mathrm{cp} / \mathrm{mck}: 3 \mathrm{c}$ & 5 & 2.2 \\
\hline 8 & cp/mck:4f & 33 & 14.7 \\
\hline 9 & $\mathrm{mck} / \mathrm{cp}: 2 \mathrm{a}$ & 1 & 0.4 \\
\hline 10 & $\mathrm{cp} / \mathrm{cb}: 1 \mathrm{a}$ & 1 & 0.4 \\
\hline 11 & $\mathrm{cp} / \mathrm{cb}: 3 \mathrm{a}$ & 2 & 0.9 \\
\hline 12 & $\mathrm{cp} / \mathrm{cb}: 3 \mathrm{~b}$ & 1 & 0.4 \\
\hline 13 & $\mathrm{cb} / \mathrm{cp}: 3 \mathrm{a}$ & 1 & 0.4 \\
\hline 14 & $\mathrm{cp} / \mathrm{po}: 1 \mathrm{a}$ & 13 & 5.8 \\
\hline 15 & $\mathrm{cp} / \mathrm{po}: 1 \mathrm{~b}$ & 21 & 9.3 \\
\hline 16 & $\mathrm{cp} / \mathrm{po}: 1 \mathrm{e}$ & 8 & 3.6 \\
\hline 17 & $\mathrm{cp} / \mathrm{po}: 2 \mathrm{~b}$ & 1 & 0.4 \\
\hline 18 & $\mathrm{cp} / \mathrm{po}: 3 \mathrm{a}$ & 4 & 1.8 \\
\hline 19 & $\mathrm{cp} / \mathrm{po}: 4 \mathrm{f}$ & 7 & 3.1 \\
\hline 20 & po/cp:1a & 19 & 8.4 \\
\hline 21 & po/cp:1b & 18 & 8.0 \\
\hline 22 & po/cp:1e & 1 & 0.4 \\
\hline 23 & $\mathrm{po} / \mathrm{cp}: 1 \mathrm{~b}, 1 \mathrm{e}$ & 1 & 0.4 \\
\hline 24 & py/po:1e & 44 & 19.6 \\
\hline 25 & $\mathrm{cp} / \mathrm{cb}: 3 \mathrm{a}, 1 \mathrm{~b}$ & 1 & 0.4 \\
\hline 26 & $(\mathrm{cp} / \mathrm{po}: 1 \mathrm{~b}) / \mathrm{mck}: 1 \mathrm{~b}$ & 2 & 0.9 \\
\hline 27 & $(\mathrm{cp} / \mathrm{cb}: 1 \mathrm{a}) / \mathrm{po}: 1 \mathrm{e}$ & 1 & 0.4 \\
\hline 28 & $(\mathrm{cp} / \mathrm{po}: 1 \mathrm{e}) / \mathrm{mck}: 1 \mathrm{~b}$ & 1 & 0.4 \\
\hline 29 & (cp/po:1b)/mck:1e & 1 & 0.4 \\
\hline 30 & $(\mathrm{cp} / \mathrm{po}: 1 \mathrm{~b}) / \mathrm{cb}: 3 \mathrm{a}$ & 1 & 0.4 \\
\hline 31 & {$[(\mathrm{cp} / \mathrm{po}: 1 \mathrm{~b}) / \mathrm{cb}: 3 \mathrm{a}] / \mathrm{mck}: 1 \mathrm{e}$} & 1 & 0.4 \\
\hline & & 225 & 100 \\
\hline
\end{tabular}

\begin{tabular}{|c|c|c|c|}
\hline & ntercrescimentos & $\begin{array}{l}\text { Soma total na } \\
\text { alteração }\end{array}$ & $\%$ \\
\hline 1 & cp/mck:1b & 5 & 13.2 \\
\hline 2 & cp/mck: $1 \mathrm{e}$ & 3 & 7.9 \\
\hline 3 & $\mathrm{cp} / \mathrm{mck}: 4 \mathrm{f}$ & 14 & 36.8 \\
\hline 4 & $\mathrm{cp} / \mathrm{po}: 1 \mathrm{a}$ & 1 & 2.6 \\
\hline 5 & $\mathrm{cp} / \mathrm{po}: 1 \mathrm{~b}$ & 1 & 2.6 \\
\hline 6 & сp/po:3a & 1 & 2.6 \\
\hline 7 & $\mathrm{cp} / \mathrm{po}: 4 \mathrm{f}$ & 1 & 2.6 \\
\hline 8 & $\mathrm{po} / \mathrm{cp}: 1 \mathrm{a}$ & 4 & 10.5 \\
\hline 9 & py/po:1e & 6 & 15.8 \\
\hline 10 & $(\mathrm{cp} / \mathrm{po}: 1 \mathrm{~b}) / \mathrm{mck}: 1 \mathrm{~b}$ & 2 & 5.3 \\
\hline & & 38 & 100.0 \\
\hline
\end{tabular}

7.3 e 7.4 - Intercrescimentos em hachurado são os mais importantes. 


\begin{tabular}{|c|c|c|c|}
\hline \multicolumn{2}{|c|}{ Intercrescimentos } & \multirow{2}{*}{$\begin{array}{l}\text { Soma total na alteração } \\
\text { Potássica=Propílica/ } \\
\text { Fílica }(\mathrm{K}=\mathrm{P} / \mathrm{F}) \\
4 \\
\end{array}$} & \multirow{2}{*}{\begin{tabular}{|l|}
$\%$ \\
6.3 \\
\end{tabular}} \\
\hline 1 & $\mathrm{cp} / \mathrm{mck}: 1 \mathrm{~b}$ & & \\
\hline 2 & cp/mck:1e & 7 & 11.1 \\
\hline 3 & $\mathrm{cp} / \mathrm{mck}: 3 \mathrm{a}$ & 1 & 1.6 \\
\hline 4 & $\mathrm{cp} / \mathrm{mck}: 4 \mathrm{f}$ & 8 & 12.7 \\
\hline 5 & $\mathrm{cp} / \mathrm{cb}: 1 \mathrm{a}$ & 2 & 3.2 \\
\hline 6 & $\mathrm{cp} / \mathrm{cb}: 1 \mathrm{~b}$ & 1 & 1.6 \\
\hline 7 & $\mathrm{cp} / \mathrm{cb}: 3 \mathrm{a}$ & 1 & 1.6 \\
\hline 8 & cp/po:1a & 2 & 3.2 \\
\hline 9 & cp/po:1b & 9 & 14.3 \\
\hline 10 & $\mathrm{cp} / \mathrm{po}: 1 \mathrm{e}$ & 1 & 1.6 \\
\hline 11 & cp/po:3a & 1 & 1.6 \\
\hline 12 & $\mathrm{cp} / \mathrm{po}: 4 \mathrm{~b}$ & 1 & 1.6 \\
\hline 13 & $\mathrm{cp} / \mathrm{po}: 4 \mathrm{f}$ & 5 & 7.9 \\
\hline 14 & $\mathrm{po} / \mathrm{cp}: 1 \mathrm{a}$ & 1 & 1.6 \\
\hline 15 & $\mathrm{po} / \mathrm{cp}: 1 \mathrm{~b}$ & 4 & 6.3 \\
\hline 16 & py/po:1e & 5 & 7.9 \\
\hline 17 & cp/po:1b,1e & 1 & 1.6 \\
\hline 18 & $(\mathrm{cp} / \mathrm{cb}: 3 \mathrm{a}) / \mathrm{mck}: 1 \mathrm{e}$ & 1 & 1.6 \\
\hline 19 & $(\mathrm{cp} / \mathrm{cb}: 1 \mathrm{a}) / \mathrm{po}: 1 \mathrm{e}$ & 1 & 1.6 \\
\hline 20 & $(\mathrm{cp} / \mathrm{cb}: 3 \mathrm{a}) / \mathrm{po}: 1 \mathrm{e}$ & 1 & 1.6 \\
\hline 21 & $(\mathrm{cp} / \mathrm{po}: 1 \mathrm{~b}) / \mathrm{mck}: 1 \mathrm{e}$ & 1 & 1.6 \\
\hline 22 & $(\mathrm{cp} / \mathrm{po}: 1 \mathrm{~b}) / \mathrm{cb}: 1 \mathrm{a}$ & 1 & 1.6 \\
\hline 23 & $(\mathrm{cp} / \mathrm{po}: 1 \mathrm{~b}) / \mathrm{cb}: 3 \mathrm{a}$ & 3 & 4.8 \\
\hline 24 & {$[(\mathrm{cp} / \mathrm{po}: 1 \mathrm{e}) / \mathrm{cb}: 3 \mathrm{a}] / \mathrm{mck}: 1 \mathrm{e}$} & 1 & 1.6 \\
\hline & & 63 & 100 \\
\hline
\end{tabular}

\begin{tabular}{|c|c|c|c|}
\hline \multicolumn{2}{|c|}{ Intercrescimentos } & \multirow{2}{*}{$\begin{array}{l}\text { Soma total na alteração } \\
\text { Propílica - Fílica (P-F) } \\
1\end{array}$} & \multirow{2}{*}{$\begin{array}{l}\% \\
2.6 \\
\end{array}$} \\
\hline 1 & $\mathrm{cp} / \mathrm{mck}: 1 \mathrm{~b}$ & & \\
\hline 2 & $\mathrm{cp} / \mathrm{mck}: 1 \mathrm{e}$ & 2 & 5.1 \\
\hline 3 & $\mathrm{cp} / \mathrm{mck}: 3 \mathrm{~b}$ & 1 & 2.6 \\
\hline 4 & $\mathrm{cp} / \mathrm{mck}: 4 \mathrm{f}$ & 6 & 15.4 \\
\hline 5 & $\mathrm{cp} / \mathrm{cb}: 3 \mathrm{a}$ & 1 & 2.6 \\
\hline 6 & cp/po:1a & 1 & 2.6 \\
\hline 7 & cp/po:1b & 8 & 20.5 \\
\hline 8 & cp/po:4f & 2 & 5.1 \\
\hline 9 & po/cp:1a & 3 & 7.7 \\
\hline 10 & py/po:1e & 5 & 12.8 \\
\hline 11 & cp/mck:3a, $1 \mathrm{e}$ & 1 & 2.6 \\
\hline 12 & $(\mathrm{cp} / \mathrm{po}: 1 b) / \mathrm{cb}: 1 \mathrm{~b}$ & 1 & 2.6 \\
\hline 13 & $(\mathrm{cp} / \mathrm{po}: 1 \mathrm{~b}) / \mathrm{mck}: 1 \mathrm{~b}$ & 2 & 5.1 \\
\hline 14 & $(\mathrm{cp} / \mathrm{cb}: 1 \mathrm{a}) / \mathrm{po}: 1 \mathrm{e}$ & 1 & 2.6 \\
\hline 15 & $(\mathrm{cp} / \mathrm{po}: 1 \mathrm{~b}) / \mathrm{mck}: 1 \mathrm{e}$ & 1 & 2.6 \\
\hline 16 & $(\mathrm{cp} / \mathrm{po}: 1 \mathrm{~b}) / \mathrm{cb}: 3 \mathrm{a}$ & 1 & 2.6 \\
\hline 17 & {$[(\mathrm{cp} / \mathrm{po}: 1 \mathrm{~b}) / \mathrm{cb}: 3 \mathrm{a}] / \mathrm{mck}: 1 \mathrm{e}$} & 1 & 2.6 \\
\hline 18 & {$[(\mathrm{cp} / \mathrm{po}: 1 \mathrm{~b}) / \mathrm{cb}: 3 \mathrm{a}] / \mathrm{mck}: 1 \mathrm{~b}$} & 1 & 2.6 \\
\hline & & 39 & 100 \\
\hline
\end{tabular}

7.5 e 7.6 - Intercrescimentos em hachurado são os mais importantes. 


\begin{tabular}{|c|c|c|c|}
\hline \multicolumn{2}{|c|}{ Intercrescimentos } & \multirow{2}{*}{$\begin{array}{c}\text { Soma total na } \\
\text { alteração Fílica - } \\
\text { Propílica (F-P) } \\
5\end{array}$} & \multirow{2}{*}{$\begin{array}{c}\% \\
3.2 \\
\end{array}$} \\
\hline 1 & cp/mck:1b & & \\
\hline 2 & $\mathrm{cp} / \mathrm{mck}: 1 \mathrm{e}$ & 6 & 3.9 \\
\hline 3 & cp/mck:3a & 1 & 0.6 \\
\hline 4 & cp/mck:3b & 1 & 0.6 \\
\hline 5 & $\mathrm{cp} / \mathrm{mck}: 4 \mathrm{f}$ & 23 & 14.8 \\
\hline 6 & $\mathrm{cp} / \mathrm{cb}: 3 \mathrm{a}$ & 6 & 3.9 \\
\hline 7 & cp/po:1a & 12 & 7.7 \\
\hline 8 & $\mathrm{cp} / \mathrm{po}: 1 \mathrm{~b}$ & 37 & 23.9 \\
\hline 9 & cp/po:1e & 10 & 6.5 \\
\hline 10 & $\mathrm{cp} / \mathrm{po}: 3 \mathrm{a}$ & 1 & 0.6 \\
\hline 11 & $\mathrm{cp} / \mathrm{po}: 4 \mathrm{f}$ & 4 & 2.6 \\
\hline 12 & $\mathrm{po} / \mathrm{cp}: 1 \mathrm{a}$ & 10 & 6.5 \\
\hline 13 & $\mathrm{po} / \mathrm{cp}: 1 \mathrm{~b}$ & 8 & 5.2 \\
\hline 14 & py/po:1e & 7 & 4.5 \\
\hline 15 & $\mathrm{cp} / \mathrm{mck}: 1 \mathrm{~b}, 1 \mathrm{e}$ & 1 & 0.6 \\
\hline 16 & $\mathrm{cp} / \mathrm{mck}: 3 \mathrm{a}, 1 \mathrm{e}$ & 1 & 0.6 \\
\hline 17 & $\mathrm{cp} / \mathrm{cb}: 3 \mathrm{a}, 1 \mathrm{a}$ & 1 & 0.6 \\
\hline 18 & $\mathrm{cp} / \mathrm{po}: 1 \mathrm{~b}, 1 \mathrm{e}$ & 1 & 0.6 \\
\hline 19 & $(\mathrm{cp} / \mathrm{cb}: 3 \mathrm{a}) / \mathrm{mck}: 3 \mathrm{a}$ & 1 & 0.6 \\
\hline 20 & $(\mathrm{cp} / \mathrm{po}: 1 \mathrm{~b}) / \mathrm{mck}: 1 \mathrm{~b}$ & 2 & 1.3 \\
\hline 21 & $\mathrm{cp} /(\mathrm{po} / \mathrm{cb}: 1 \mathrm{a}): 1 \mathrm{~b}$ & 1 & 0.6 \\
\hline 22 & $\mathrm{cp} /(\mathrm{po} / \mathrm{cb}: 1 \mathrm{~b}): 1 \mathrm{~b}$ & 1 & 0.6 \\
\hline 23 & $(\mathrm{cp} / \mathrm{cb}: 3 \mathrm{a}) / \mathrm{mck}: 1 \mathrm{~b}$ & 1 & 0.6 \\
\hline 24 & $(\mathrm{cp} / \mathrm{cb}: 1 \mathrm{a}) / \mathrm{po}: 1 \mathrm{e}$ & 2 & 1.3 \\
\hline 25 & $(\mathrm{cp} / \mathrm{cb}: 3 \mathrm{a}) / \mathrm{po}: 1 \mathrm{e}$ & 5 & 3.2 \\
\hline 26 & $(\mathrm{cp} / \mathrm{po}: 1 \mathrm{~b}) / \mathrm{mck}: 1 \mathrm{e}$ & 2 & 1.3 \\
\hline 27 & $(\mathrm{cp} / \mathrm{po}: 1 \mathrm{~b}) / \mathrm{mck}: 4 \mathrm{f}$ & 1 & 0.6 \\
\hline 28 & $(\mathrm{cp} / \mathrm{po}: 1 \mathrm{~b}) / \mathrm{cb}: 1 \mathrm{a}$ & 1 & 0.6 \\
\hline 29 & $(\mathrm{cp} / \mathrm{po}: 1 \mathrm{~b}) / \mathrm{cb}: 3 \mathrm{a}$ & 3 & 1.9 \\
\hline & & 155 & 100 \\
\hline
\end{tabular}

\begin{tabular}{|c|c|c|c|}
\hline & ntercrescimentos & $\begin{array}{l}\text { Soma total na } \\
\text { alteração Fílica }\end{array}$ & $\%$ \\
\hline 1 & cp/mck:1b & 13 & 9.8 \\
\hline 2 & $\mathrm{cp} / \mathrm{mck}: 1 \mathrm{c}$ & 1 & 0.8 \\
\hline 3 & cp/mck:1e & 8 & 6.0 \\
\hline 4 & $\mathrm{cp} / \mathrm{mck}: 3 \mathrm{a}$ & 1 & 0.8 \\
\hline 5 & $\mathrm{cp} / \mathrm{mck}: 3 \mathrm{~b}$ & 8 & 6.0 \\
\hline 6 & $\mathrm{cp} / \mathrm{mck}: 3 \mathrm{c}$ & 9 & 6.8 \\
\hline 7 & $\mathrm{cp} / \mathrm{mck}: 4 \mathrm{f}$ & 25 & 18.8 \\
\hline 8 & $\mathrm{cp} / \mathrm{cb}: 1 \mathrm{a}$ & 2 & 1.5 \\
\hline 9 & $\mathrm{cp} / \mathrm{cb}: 3 \mathrm{a}$ & 2 & 1.5 \\
\hline 10 & $\mathrm{cp} / \mathrm{po}: 1 \mathrm{a}$ & 1 & 0.8 \\
\hline 11 & $\mathrm{cp} / \mathrm{po}: 1 \mathrm{~b}$ & 29 & 21.8 \\
\hline 12 & $\mathrm{cp} / \mathrm{po}: 1 \mathrm{e}$ & 4 & 3.0 \\
\hline 13 & cp/po:3a & 1 & 0.8 \\
\hline 14 & $\mathrm{cp} / \mathrm{po}: 4 \mathrm{f}$ & 1 & 0.8 \\
\hline 15 & po/cp:1a & 3 & 2.3 \\
\hline 16 & $\mathrm{po} / \mathrm{cp}: 1 \mathrm{~b}$ & 5 & 3.8 \\
\hline 17 & py/po:1e & 9 & 6.8 \\
\hline 18 & $\mathrm{cp} / \mathrm{mck}: 1 \mathrm{~b}, 1 \mathrm{e}$ & 1 & 0.8 \\
\hline 19 & $(\mathrm{cp} / \mathrm{po}: 1 \mathrm{~b}) / \mathrm{cb}: 1 \mathrm{~b}$ & 1 & 0.8 \\
\hline 20 & $(\mathrm{cp} / \mathrm{cb}: 3 \mathrm{a}) / \mathrm{po}: 1 \mathrm{e}$ & 2 & 1.5 \\
\hline 21 & $(\mathrm{cp} / \mathrm{po}: 1 \mathrm{~b}) / \mathrm{cb}: 1 \mathrm{a}$ & 1 & 0.8 \\
\hline 22 & $(\mathrm{cp} / \mathrm{po}: 1 \mathrm{~b}) / \mathrm{cb}: 3 \mathrm{a}$ & 5 & 3.8 \\
\hline 23 & $(\mathrm{cp} / \mathrm{po}: 1 \mathrm{~b}) / \mathrm{cb}: 3 \mathrm{a}, 1 \mathrm{a}$ & 1 & 0.8 \\
\hline & & 133 & 100 \\
\hline
\end{tabular}

7.7 e 7.8 - Intercrescimentos em hachurado são os mais importantes. 


\section{ANEXO 8}

\section{PERFIS COM A RELAÇÃO DOS MINERAIS QUE TIPIFICAM AS INCLUSÕES E AS ALTERAÇÕES HIDOTERMAIS}

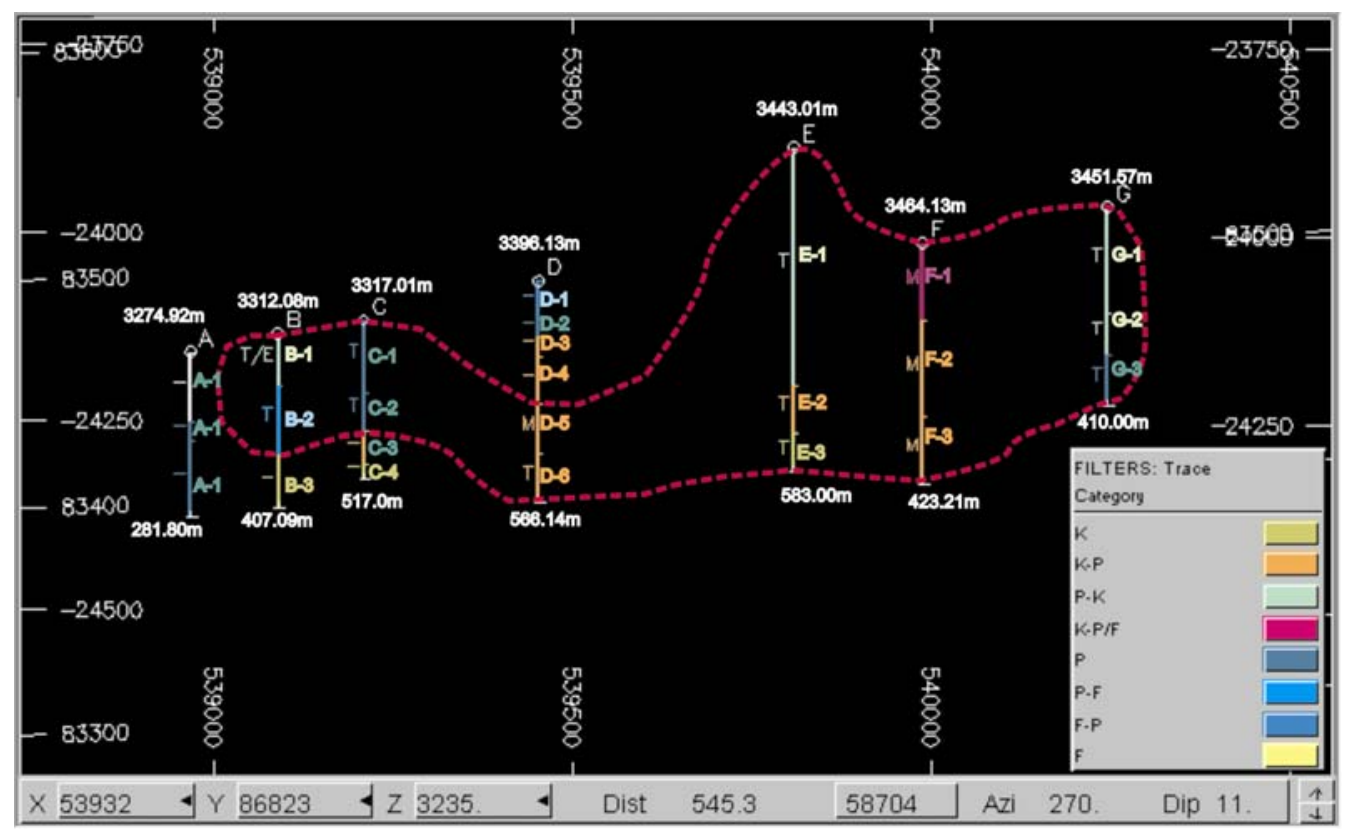

8.1: Distribuição da pirrotita nos diferentes tipos de alterações presentes no perfil 1. Á direita de cada furo de sondagem se mostra o código da amostra e a esquerda a categoria estabelecida na tabela 7.2 , as cotas e profundidades na parte superior e inferior.

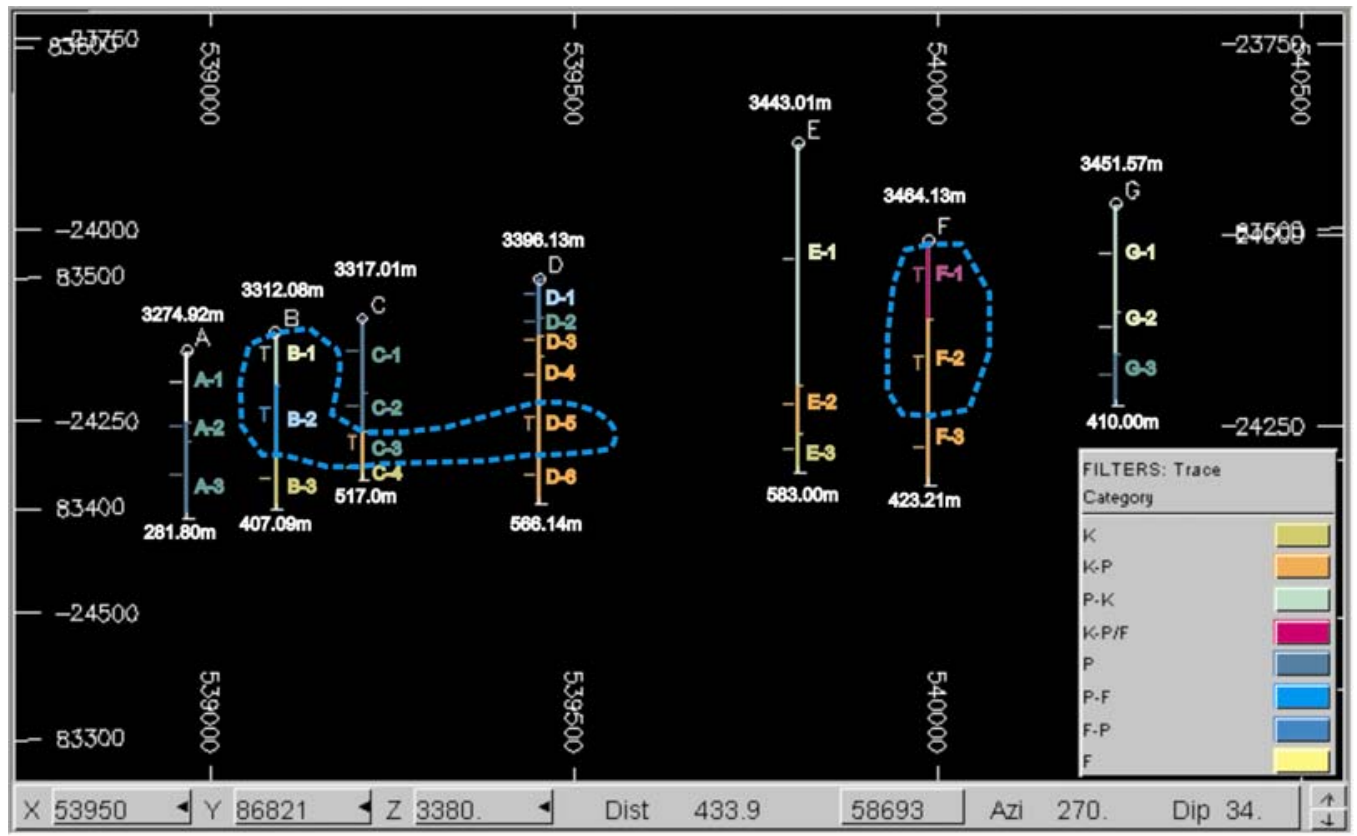

8.2: Distribuição da cubanita nos diferentes tipos de alterações presentes no perfil 1. Á direita de cada furo de sondagem se mostra o código da amostra e a esquerda a categoria estabelecida na tabela 7.2, as cotas e profundidades na parte superior e inferior. 


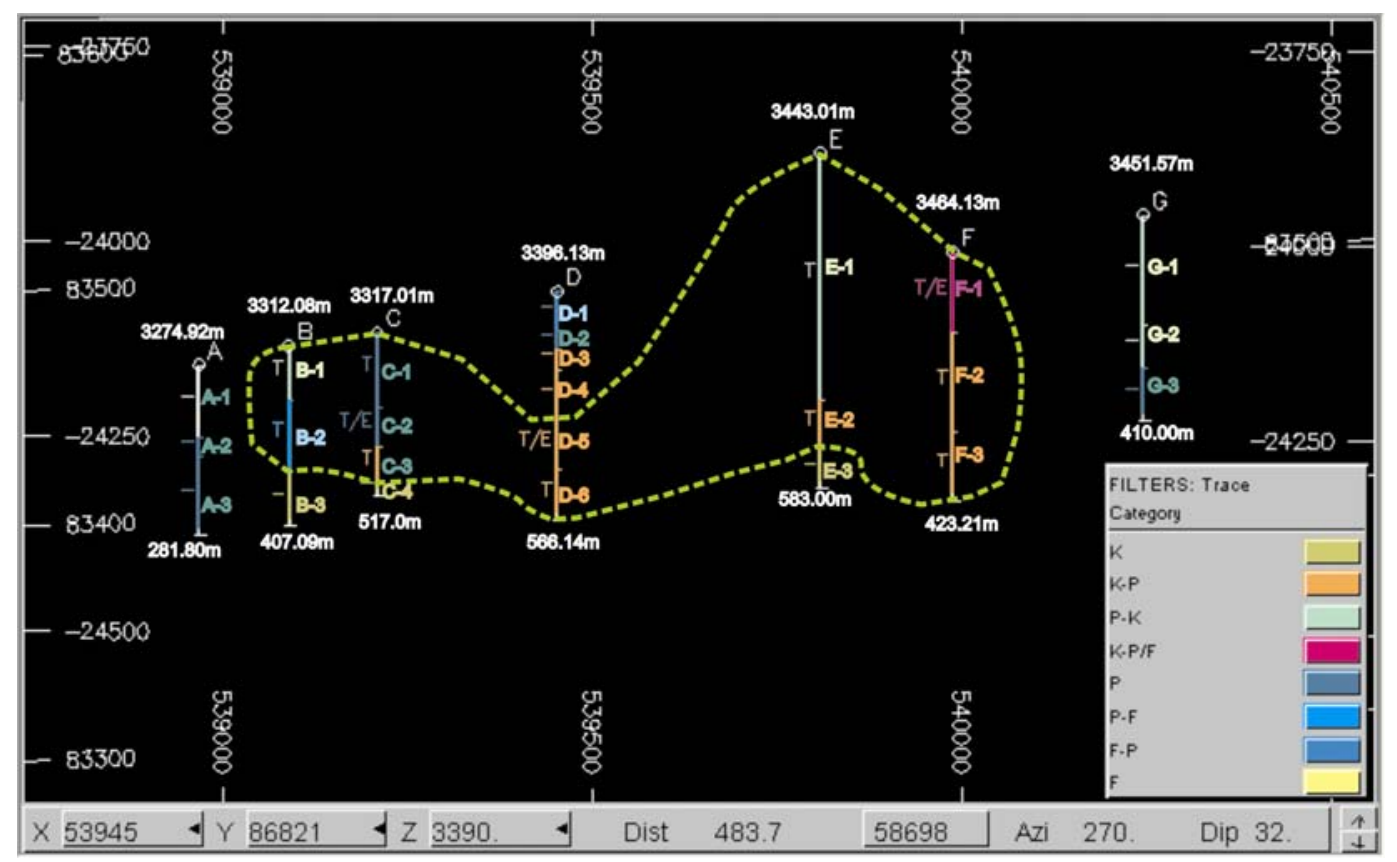

8.3: Distribuição da mackinawita nos diferentes tipos de alterações presentes no perfil 1. Á direita de cada furo de sondagem se mostra o código da amostra e a esquerda a categoria estabelecida na tabela 7.2 , as cotas e profundidades na parte superior e inferior.

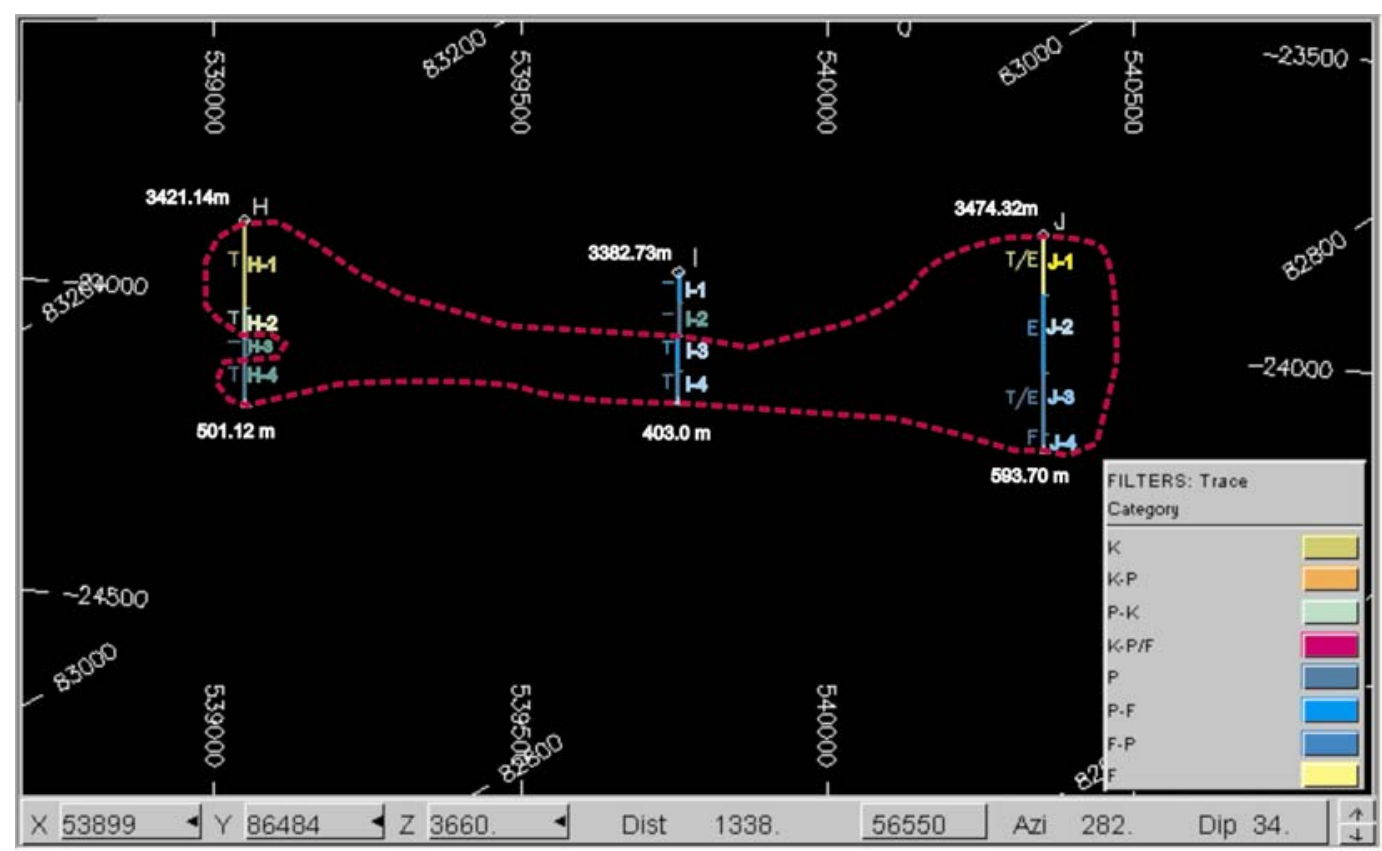

8.4: Distribuição da pirrotita nos diferentes tipos de alterações presentes no perfil 2. Á direita de cada furo de sondagem se mostra o código da amostra e a esquerda a categoria estabelecida na tabela 7.2 , as cotas e profundidades na parte superior e inferior. 


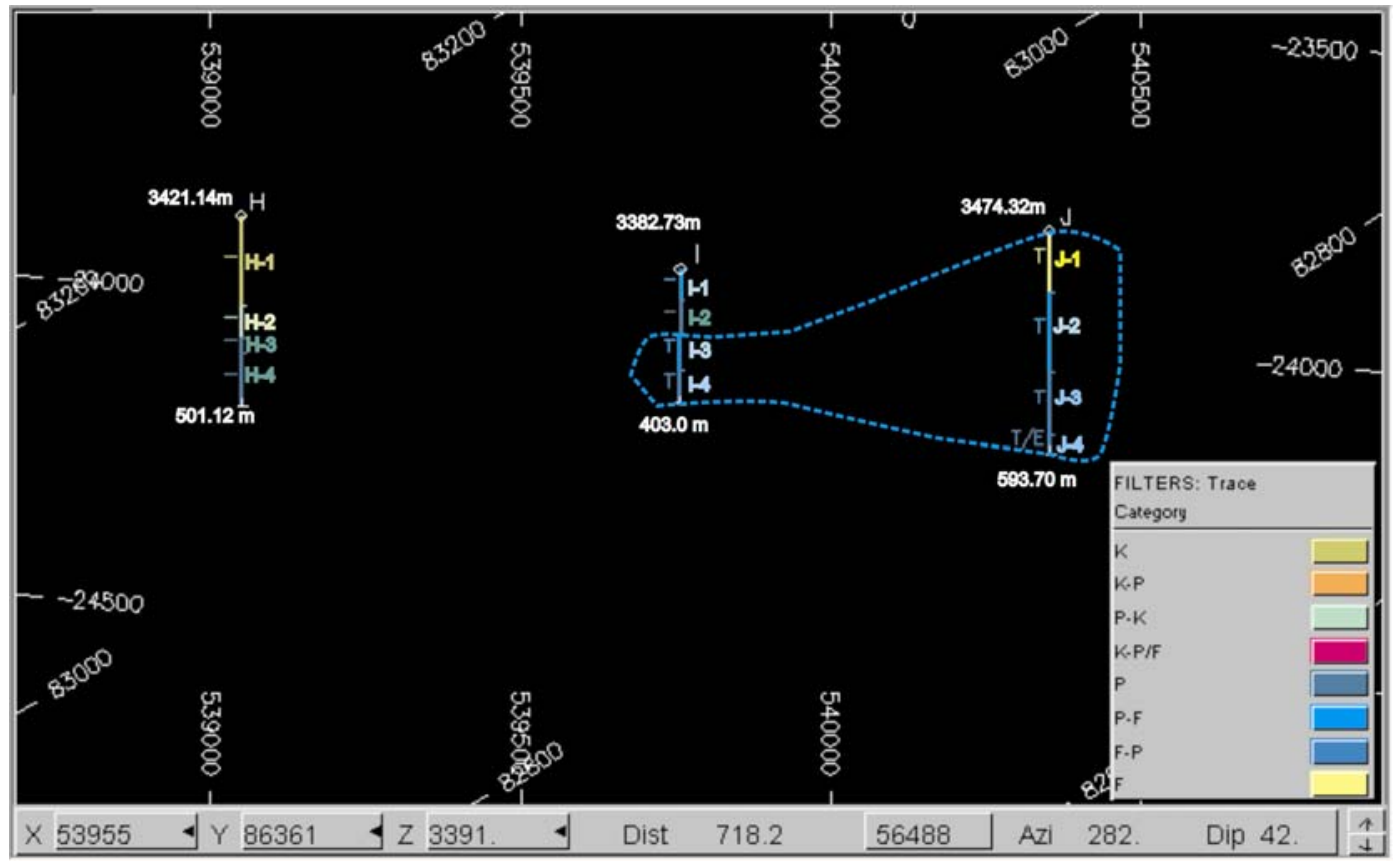

8.5: Distribuição da cubanita nos diferentes tipos de alterações presentes no perfil 2. Á direita de cada furo de sondagem se mostra o código da amostra e a esquerda a categoria estabelecida na tabela 7.2 , as cotas e profundidades na parte superior e inferior.

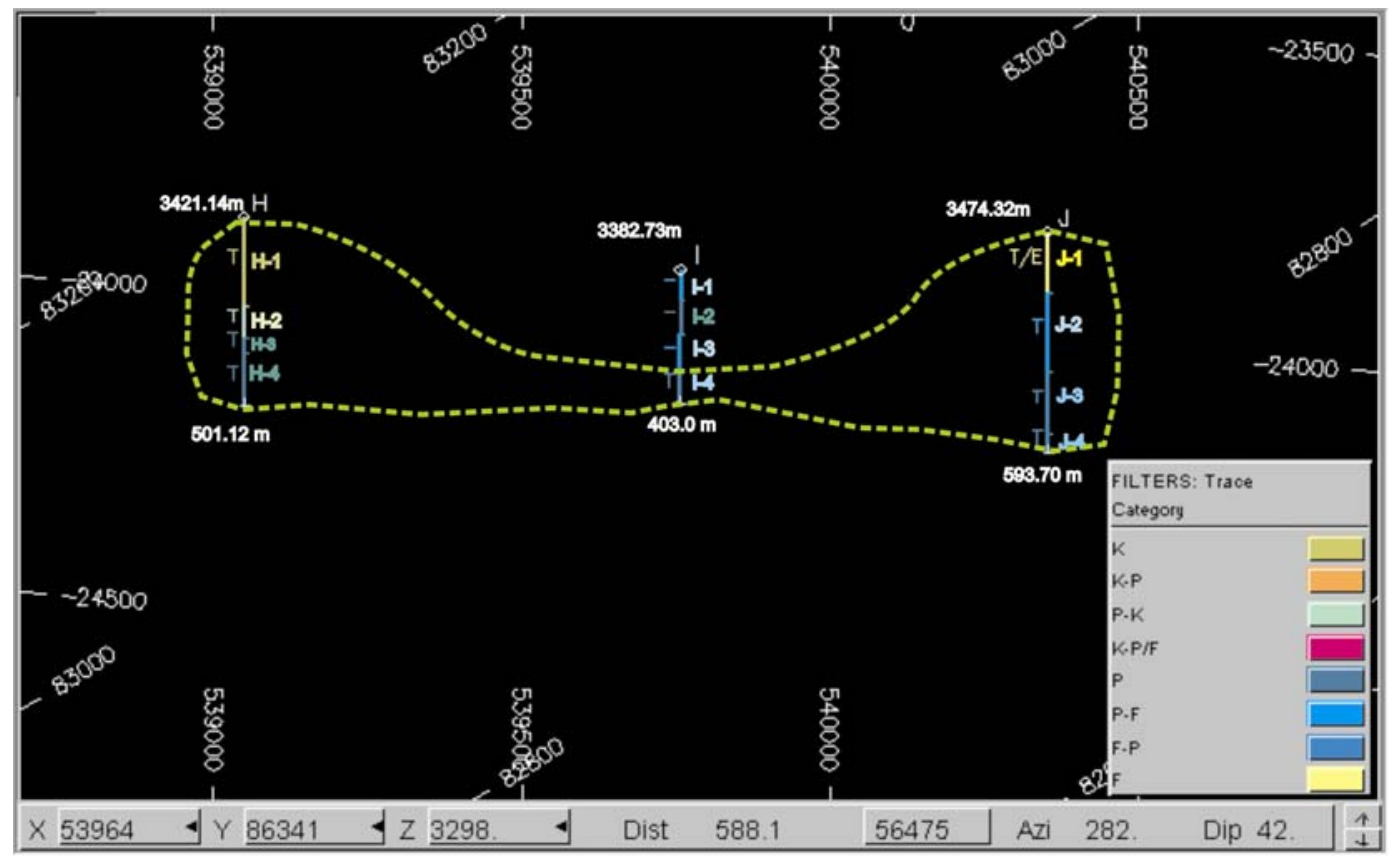

8.6: Distribuição da mackinawita nos diferentes tipos de alterações presentes no perfil 2. Á direita de cada furo de sondagem se mostra o código da amostra e a esquerda a categoria estabelecida na tabela 7.2, as cotas e profundidades na parte superior e inferior. 


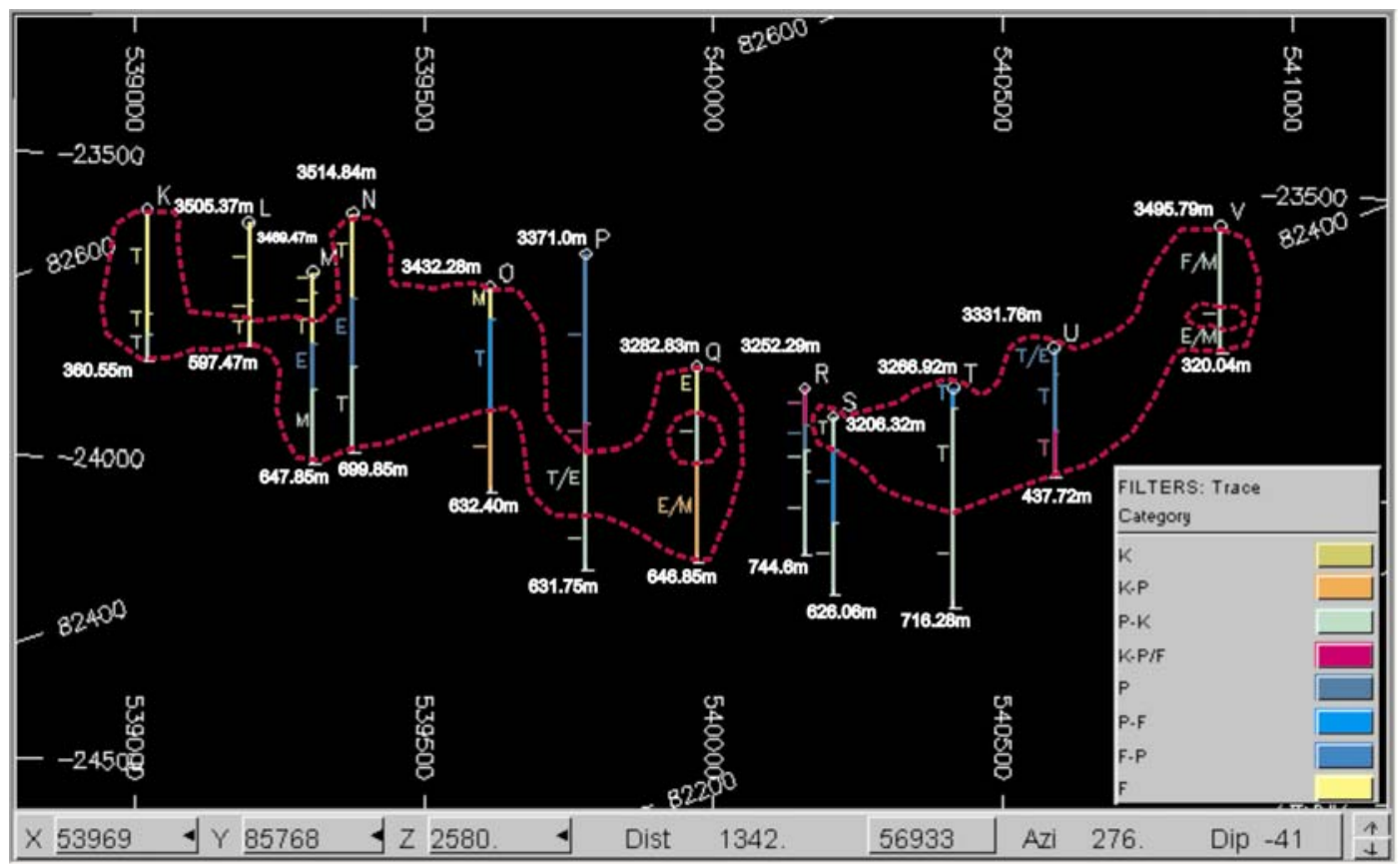

8.7: Distribuição da pirrotita nos diferentes tipos de alterações presentes no perfil 3. Á direita de cada furo de sondagem se mostra o código da amostra e a esquerda a categoria estabelecida na tabela 7.2 , as cotas e profundidades na parte superior e inferior.

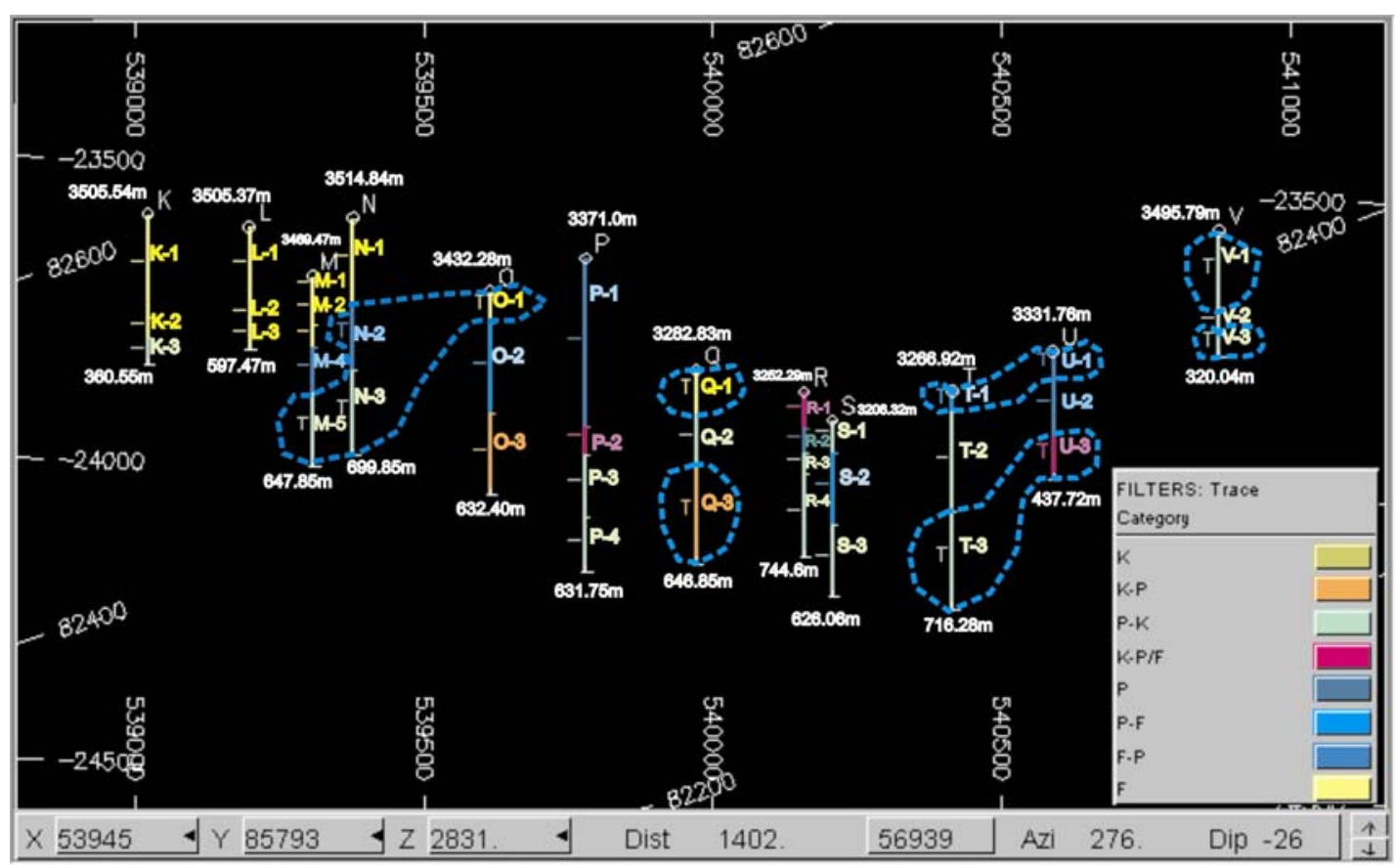

8.8: Distribuição da cubanita nos diferentes tipos de alterações presentes no perfil 3. Á direita de cada furo de sondagem se mostra o código da amostra e a esquerda a categoria estabelecida na tabela 7.2 , as cotas e profundidades na parte superior e inferior. 


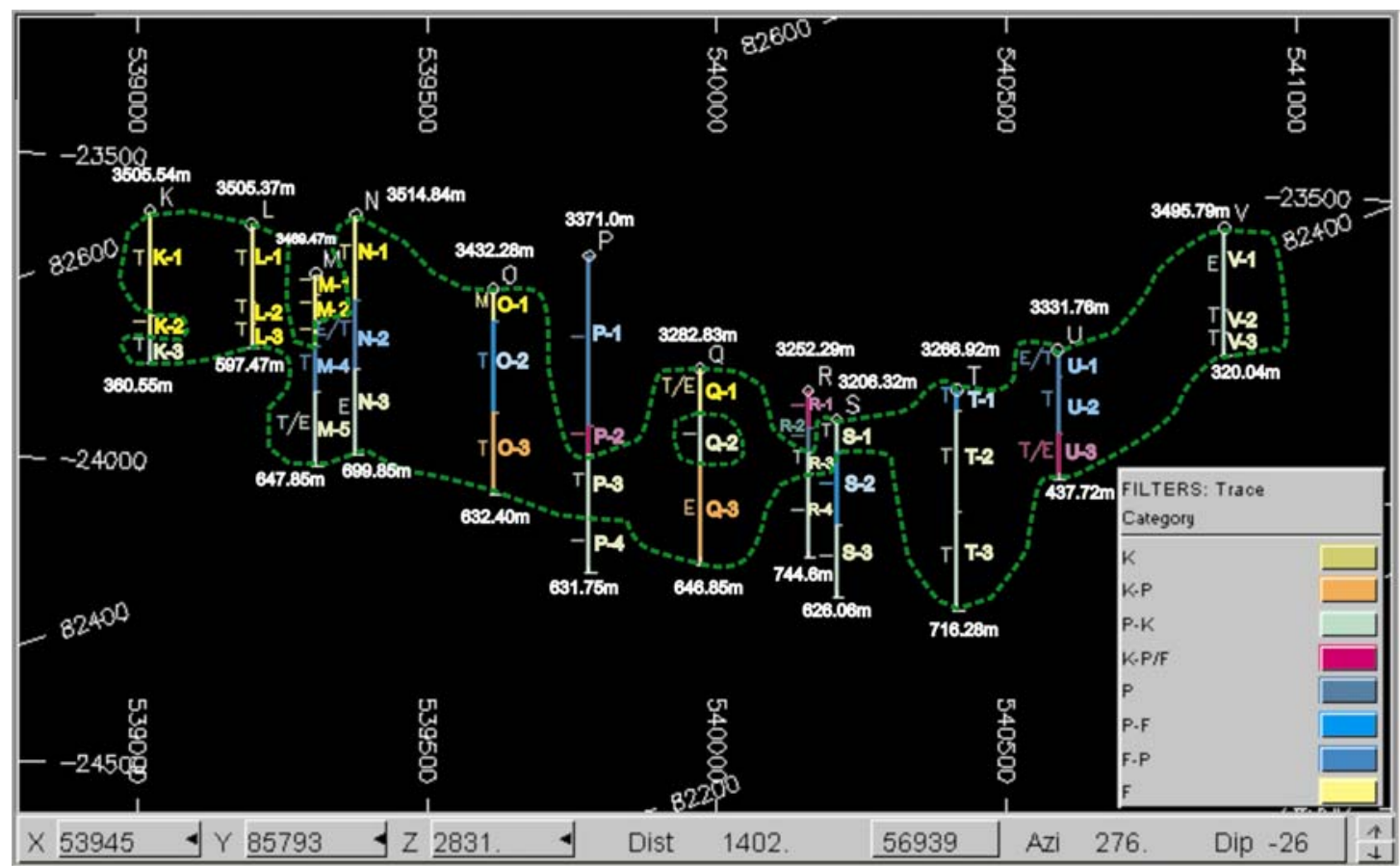

8.9: Distribuição da mackinawita nos diferentes tipos de alterações presentes no perfil 3. Á direita de cada furo de sondagem se mostra o código da amostra e a esquerda a categoria estabelecida na tabela 7.2 , as cotas e profundidades na parte superior e inferior. 